

\section{A Arquitetura no Processo de Humanização dos Ambientes Hospitalares}

Ricardo José Alexandre Simon Ciaco

Orientador: João Marcos de Almeida Lopes

Dissertacão apresentada ao Programa de Pós-Graduação em Arquitetura e Urbanismo da EESC / USP como

requisito parcial no programa de MESTRADO na área de ARQUITETURA, URBANISMO E TECNOLOGIA.

São Carlos

2010 


Ciaco, Ricardo José Alexandre Simon
A arquitetura no processo de humanização dos ambientes
hospitalares / Ricardo José Alexandre Simon Ciaco i
orientador João Marcos de Almeida Lopes. -- São Carlos,
2010.
Dissertação (Mestrado-Programa de Pós-Graduação em
Arquitetura e Urbanismo. Area de concentração em
Arquitetura, Urbanismo e Tecnologia) -- Escola de
Engenharia de São Carlos da Universidade de são Paulo,
2010.
1. Edifícios hospitalares. 2. Humanização. 3. Projetos
hospitalares. A. João Felgueiras Lima. 5. Lelé.
6. Utente. 7. Conforto ambiental. I. Título.


Folha de Julgamento

Candidato(a): Arquiteto e Urbanista RICARDO JOSÉ SIMON CIACO.

Dissertação defendida e julgada em 24/03/2010 perante a Comissão Julgadora:

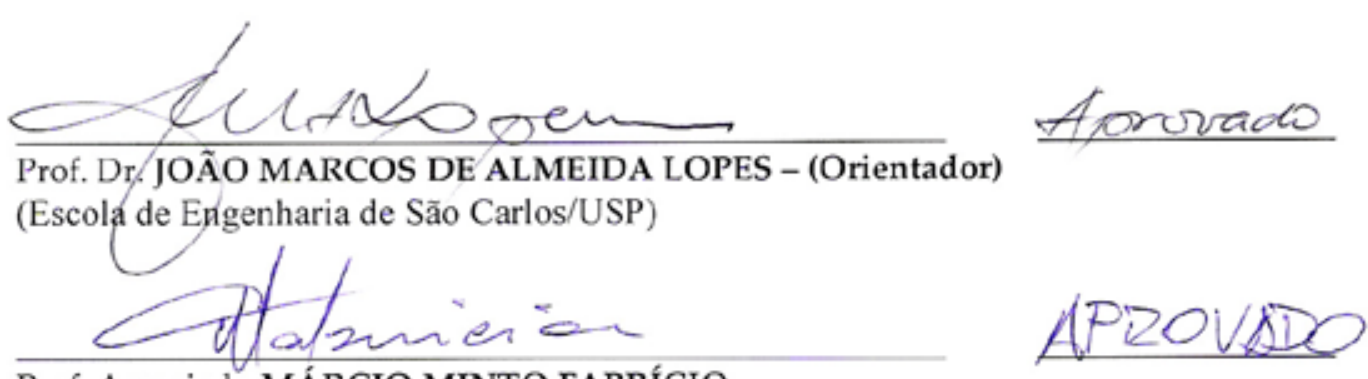

Prof. Associado MÁRCIO MINTO FABRíCIO

(Escola de Engenharia de São Carlos/USP)

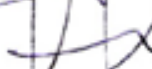

Prof. Dr. FABFO OLIVEIRA BITTENCOURT FILHO

$\triangle P R \triangle V A D O$

(Universidade Estácio de Sá/UNESA)

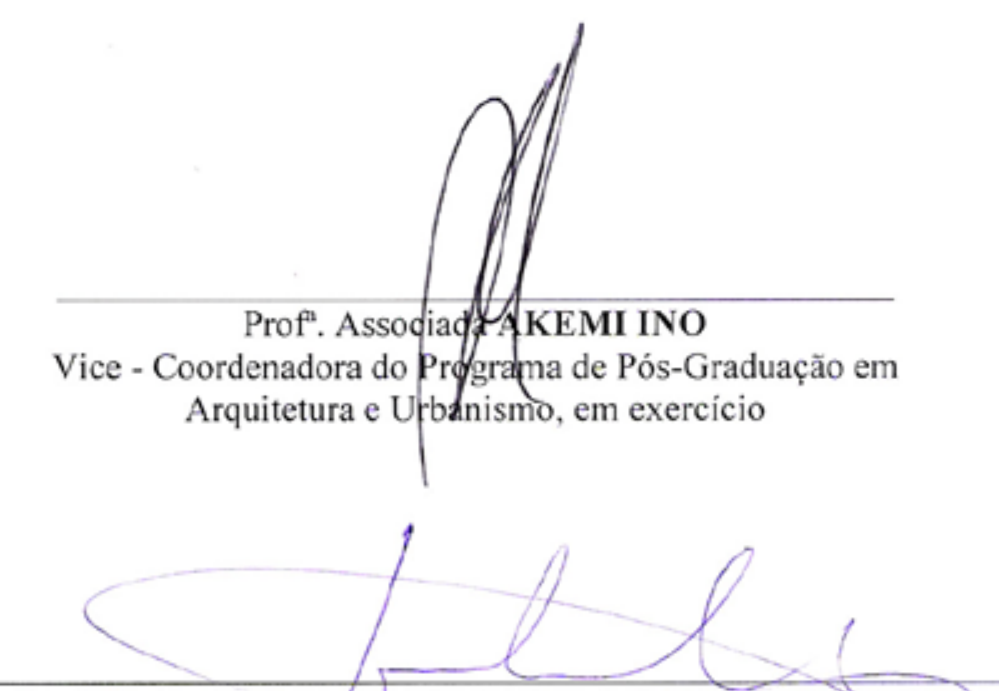

Prof. Titular GERALDO ROBERTO MARTINS DA COSTA Presidente da Comissão da Pós-Graduação da EESC 
Este trabalho é dedicado

à Daniela e ao Teo. 


\section{Agradecimentos}

Ao meu orientador. Prof. Dr. João Marcos Almeida Lopes que comigo compartilhou não somente o desenvolvimento desta dissertação como também a experiência de ter um novo membro na família;

Aos meus amigos e à família, principalmente aos meus pais, grandes incentivadores, e aos meus irmãos, que ofereceram em todos os aspectos muito apoio no período de estudos.

Um agradecimento especial à minha esposa Daniela que juntamente com meu filho Teo souberam entender minha ausência nesse período de dedicação ao mestrado:

Aos meus colegas de trabalho Ronaldo e Júnior, que no escritório cuidaram perfeitamente de tudo em minha ausência. Também à futura arquiteta Maria Paula que muito me ajudou.

Aos funcionários das instituições visitadas, em especial ao Ivo Stigger da Santa Casa de Porto Alegre pela sua dedicação naquilo que Ihe foi possível, quando da minha visita à instituição.

Aos professores presentes nas bancas de qualificação e defesa através de suas colocações e orientações muito contribuiram para o resultado final do trabalho. 


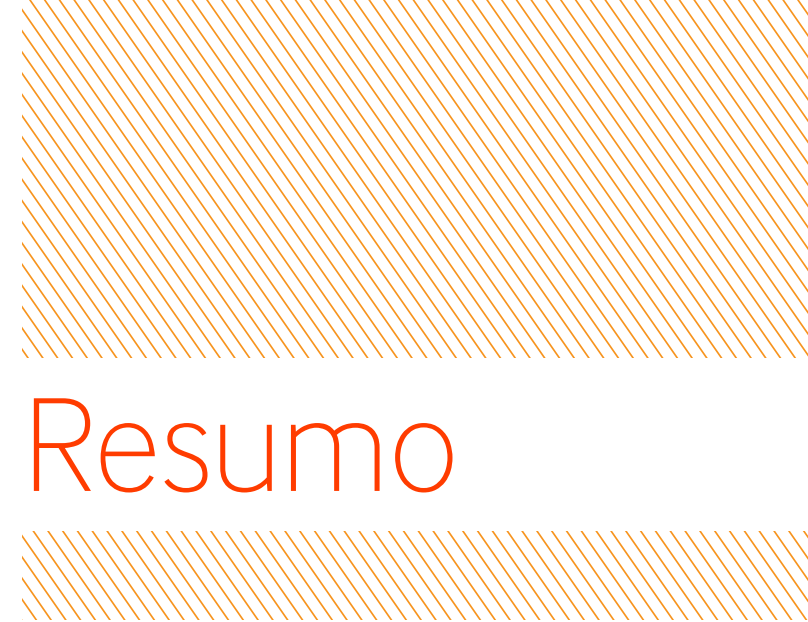

CIACO, R. J. A.S. (2010). Arquitetura no Processo de Humanização dos Ambientes Hospitalares. Dissertação (Mestrado) - Escola de Engenharia de São Carlos, Universidade de São Paulo, São Carlos, 2010.

A questão da humanização hospitalar parece ser temática bastante recorrente hoje, nas ciências da saúde, bem como na arquitetura. Este estudo visa compreender, através de um olhar voltado para a arquitetura, a estruturação e as práticas dos processos de humanização nos ambientes hospitalares. Para tanto, realizam-se incursões teóricas para melhor precisar o conceito de humanização em uma abordagem arquitetônica, tanto na perspectiva do utente, quanto na do trabalhador da saúde, bem como se realiza uma revisão da legislação que trata do assunto, visando uma melhor compreensão do papel do Sistema Único de Saúde no processo de humanização hospitalar. Ainda a partir de uma abordagem teórica, procura-se estabelecer parâmetros que possibilitem avaliar se estabelecimentos assistenciais de saúde podem ou não ser considerados humanizados, tentando-se elencar os requisitos básicos para se desenvolver uma arquitetura eficiente quanto à humanização desse ambientes. $A$ partir dos referenciais teóricos da humanização hospitalar nas suas relaç̃oes com a arquitetura, partese para uma análise de campo que permita, a partir das práticas em curso nos hospitais, verificar se há efetivamente uma preocupação de desenvolvimento e implantação de uma arquitetura voltada para a questão da humanização, bem como se os requisitos arquitetônicos apontados teoricamente dão conta e são suficientes para se pensar em uma arquitetura com tal propósito.

Nossa hipótese é a de que como nos hospitais públicos há menor disponibilidade de recursos, a preocupação com a humanização volta-se exclusivamente para os princípios essenciais e básicos de uma arquitetura preocupada com questão, sendo esses princípios arquitetônicos por si sós já suficientes para garantir um nível adequado de humanização no ambiente hospitalar. Desta maneira, o corpus de análise volta-se para o sistema público de saúde, elencando-se quatro estabelecimentos assistenciais de saúde que atendem preferencialmente usuários do SUS, em diferentes portes e complexidades operacionais, possibilitando assim uma visão prática mais abrangente. São eles o Hospital Escola Municipal de São Carlos, o Hospital do Câncer de Barretos, a Santa Casa de Porto Alegre e a Santa Casa de São João da Boa Vista. Desta forma, espera-se então entender se nos hospitais destinados ao atendimento público a presença da arquitetura, por meio de requisitos básicos, é eficiente na humanização dos ambientes. E. por fim, fornecer subsídios para a estruturação de uma arquitetura hospitalar mais eficiente na questão da humanização.

Palavras-chave: edifícios hospitalares: humanização; arquitetura hospitalar: projetos hospitalares: João Filgueiras Lima; Lelé; utente; conforto. 

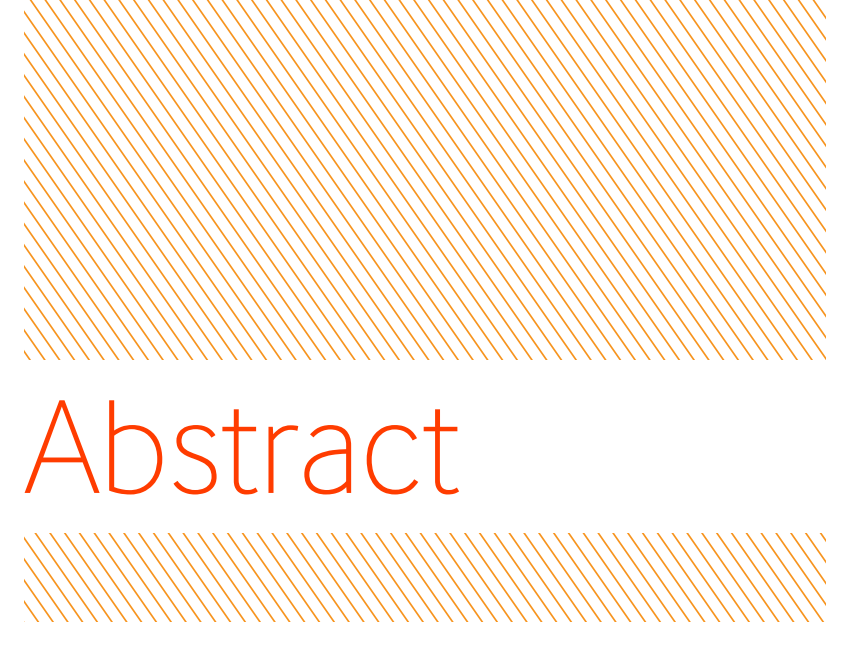

CIACO, R. J. A. S. (2010). The architecture in the process of humanization of hospitalar ambients. Tesis (Master). Escola de Engenharia de São Carlos, Universidade de São Paulo, São Carlos, 2010.

The matter of hospitalar humanization seems to be subject quite recurring nowadays in the sciences of health, as well as in architecture. This study aims to understand through the architecture point of view the structuring and the practices of the humanization processes within the hospitalar ambient. For this intention, it will be realized theoretical incursions for better precise the concept of humanization in an architectonical approach, either through the patient or the employee of the health area perspectives, as well as it will be revised the legislation about the subject in order to better comprehend the function of the Sistema Único de Saúde (SUS) within the process of hospitala humanization. Still through a theoretical approach, it is expected to establish parameters that make possible to evaluate if the health buildings either or not can be considered humanized, trying to map the basic requirements for the development of an efficient architecture focused on the humanization of hospitalar ambients.

From this theoretical approach of the hospitalar humanization within its relationship with architecture a field analysis is implemented in order to verify in the hospitalar practices if there is a real concern in developing and implementing an architecture focused on the humanization, as well as if the architectonic requirements identified in the theory were enough to reflect an architecture with this intention.

Our hypothesis is that since the public hospitals have lower availability of resources, the concern with the humanization is exclusively related to the essential and basic principles of an architecture worried with the issue, being these architectonic requirements enough for ensuring an adequate leve of humanization of the hospital ambient. Thus the analysis corpus will be the public health system considering four hospitals that serve preferentially SUS patients, with different sizes and complexity of operation: Hospital Escola Municipal de São Carlos, Hospital do Câncer de Barretos, Santa Casa de Porto Alegre and Santa Casa de São João da Boa Vista. We expect to understand if in these public hospitals the presence of the basic architectonic requirements are enough and sufficient for the humanization of the ambients. At last, we intend to provide contribution for the development of a hospitalar architecture more efficient and worried with the question of humanization.

Key words: hospitalar edifice: humanization; hospitalar architecture; hospitalar project; João Filgueiras Lima; Lelé; patient; comfort. 


\section{Lista de Imagens}

\section{FIG. 1 - P.48}

Tabela ilustrativa retirada da RDC $\mathrm{n} .50$

FIG. 2 - P. 109

Implantação do Hospital Escola Municipal

de São Carlos destacando etapa da obra já

concluída109

FIG. 3 - P. 110

Fotos gerais do Hospital Escola Municipal de

São Carlos

FIG. 4 - P. 112

Foto aérea do Hospital do Câncer de Barretos

FIG. 5 - P.114

Fotos do pavilhão destinado à prevenção no

Hospital do Câncer de Barretos

FIG. 6 - P. 115

Fotos dos veículos utilizados nas campanhas de

prevenção contra o câncer em comunidades

carentes de atendimento

FIG. 7 - P. 117

Fotos das áreas destinadas a descanso e estudo

dos médicos do Hospital do Câncer de Barretos

\section{FIG. 8 - P. 119}

Folder de divulgação das formas de doação

com as quais conta o Hospital do Câncer de Barretos

FIG. 9 - P. 120

Fotos de caminhão descarregando doações feitas ao Hospital do Câncer de Barretos

\section{FIG. 10 - P. 120}

Implantação esquemática do Hospital do

Câncer de Barretos
FIG. 11 - P. 122

Fotos demonstrativas das varandas de

circulação periférica do Hospital do Câncer de Barretos

FIG. 12 - P. 123

Fotos ilustrativas dos ambientes de uso comum do Hospital do Câncer de Barretos

FIG. 13 - P. 126

Implantacão esquemática do complexo da Santa Casa de Porto Alegre

FIG. 14 - P. 126

Figura ilustrativa do sistema funcional orbital do complexo da Santa Casa de Porto Alegre

FIG. 15 - P. 134

Foto aérea da Santa Casa Dona Carolina Malheiros com a construção inicial

\section{FIG. 16 - P. 134}

Folder de divulgação do resultado das

campanhas para angariar fundos para reformas da Santa Casa Dona Carolina Malheiros

\section{FIG. 17 - P. 138}

Foto da Santa Casa Dona Carolina Malheiros

com a identificação das instalações

FIG. 18 - P. 141

Foto ilustrativa da enfermaria destinada aos

usuários de convênios e particulares da Santa

Casa Dona Carolina Malheiros

\section{FIG. 19 - P.141}

Fotos das áreas de uso comum da ala destinada aos usuários de convênios e particulares da Santa Casa Dona Carolina Malheiros 
FIG. 20 - P. 142

Fotos ilustrativas das enfermarias masculinas e femininas destinadas ao SUS, na Santa Casa Dona Carolina Malheiros

\section{FIG. 21-P. 142}

Fotos ilustrativas da recepção e circulação do ambulatório da Santa Casa Dona Carolina Malheiros

\section{FIG. 22 - P.143}

Fotos llustrativas do setor de radioterapia e quimioterapia da Santa Casa Dona Carolina Malheiros

\section{FIG. 23 - P. 147}

Fotos do Hospital do Câncer de Barretos mostrando piso utilizado

\section{FIG. 24 - P. 148}

Fotos da Santa Casa de Porto Alegre mostrando os pisos utilizados

\section{FIG. 25 - P. 148}

Fotos da Santa Casa Dona Carolina Malheiros mostrando os pisos utilizados

\section{FIG. 26 - P. 151}

Fotos da área destinada aos médicos -

biblioteca e setor das salas privativas no Hospital do Câncer de Barretos

\section{FIG. 27 - P. 151}

Fotos do Hospital do Câncer de Barretos - sala de descanso para médicos e enfermeiros e de estar defronte sala de estudos dos médicos

\section{FIG. 28 - P. 152}

Foto da praça central do Complexo da Santa Casa de Porto Alegre

\section{FIG. 29 - P. 153}

Foto da área de descanso dos funcionários da Santa Casa Dona Carolina Malheiros
FIG. 30 - P. 156

Foto do Hospital do Câncer de Barretos tomada via satélite

\section{FIG. 31 - P. 158}

Foto de satélite e aérea atual ilustrando

situação da implantação da Santa Casa Dona

Carolina Malheiros 158

\section{FIG. 32 - P. 159}

Fotos ilustrativas dos antigos espaços vazios

entre os pavilhões da Santa Casa Dona Carolina Malheiros

FIG. 33 - P. 165

Croqui ilustrativo da área em funcionamento do Hospital Escola Municipal de São Carlos com esquema das circulações

\section{FIG.34 - P. 166}

Croqui ilustrativo da implantação de todo o Hospital Escola Municipal de São Carlos com esquema de circulação

\section{FIG. 35 - P. 167}

Implantaç̃̃o esquemática do Hospital do

Câncer de Barretos

FIG. 36 - P. 167

Foto aérea do Hospital do Câncer de Barretos

\section{FIG. 37 - P. 168}

Esquema ilustrativo das circulações do Hospital do Câncer de Barretos

\section{FIG. 38 - P. 168}

Fotos ilustrativas das circulações técnica e externa do Hospital do Câncer de Barretos

\section{FIG. 39 - P. 170}

Foto do Hospital Dom Vicente Scherer no

Complexo da Santa Casa de Porto Alegre
FIG. 40 - P. 171

Foto do Hospital Santa Clara no Complexo da Santa Casa de Porto Alegre

\section{FIG. 41 -P.172}

Fotos ilustrativas das passarelas que ligam os hospitais do complexo da Santa Casa de Porto Alegre

\section{FIG. 42 - P. 173}

Croqui esquemático da distribuição original do

Pavimento térreo da Santa Casa Dona Carolina Malheiros

\section{FIG. 43 - P. 173}

Croqui esquemático da distribuição original do primeiro pavimento da Santa Casa Dona Carolina Malheiros

\section{FIG. 44 - P. 174}

Croqui esquemático da distribuição original do segundo pavimento da Santa Casa Dona Carolina Malheiros

\section{FIG. 45 - P. 175}

Croqui esquemático de distribuição atual do pavimento térreo da Santa Casa Dona Carolina Malheiros

\section{FIG. 46 - P. 176}

Croqui esquemático de distribuição atual

do primeiro pavimento da Santa Casa Dona Carolina Malheiros

\section{FIG. 47 - P. 176}

Croqui esquemático de distribuição atual do segundo pavimento da Santa Casa Dona Carolina Malheiros

\section{FIG. 48 - P.183}

Fotos ilustrativas das varandas externas de circulação do Hospital do Câncer de Barretos
FIG. 49 - P. 184

Fotos ilustrativas das áreas de uso comum do Hospital do Câncer de Barretos

\section{FIG. 50 - P. 185}

Fotos das áreas internas do Hospital do Câncer de Barretos

FIG. 51 - P. 186

Fotos das áreas internas dos hospitais do

complexo da Santa Casa de Porto Alegre

\section{FIG. 52 - P. 187}

Foto da vista externa, a partir das enfermarias

suS, da Santa Casa Dona Carolina Malheiros

\section{FIG. 53 - P. 188}

Foto da circulação interna da Santa Casa Dona Carolina Malheiros

\section{FIG. 54 - P. 188}

Fotos ilustrativas das enfermarias do SUS da Santa Casa Dona Carolina Malheiros

\section{FIG. 55 - P. 189}

Fotos de áreas internas de uso comum da

Santa Casa Dona Carolina Malheiros

\section{FIG. 56 - P. 190}

Fotos ilustrativas do Hospital Escola Municipa

de São Carlos

\section{FIG. 57 - P. 191}

Fotos ilustrativas das áreas externas do Hospita do Câncer de Barretos

FIG. 58 - P. 192

Fotos ilustrativas do complexo da Santa Casa de Porto Alegre

\section{FIG. 59 - P. 194}

Fotos ilustrativas de ambientes do complexo da Santa Casa de Porto Alegre 


\section{Sumário}

\section{Capítulo 1:}

Contextualizando a humanização

\section{Capítulo 2:}

Percursos metodológicos

2.1 Definição do objeto de estudo

Definição do corpus

2.3 Hipótese

2.4 Objetivo

\section{Capítulo 3}

JArquitetura e humanização: abordagens teóricas

$3.1 \quad$ Utente

3.2 Legislação

3.3 SUS - Sistema Único de Saúde

34 Humanizasus

3.5 Humanização

3.6 Arquitetura para estabelecimentos assistenciais de saúde

3.6.1 Requisitos básicos

A. Adequação ao local

B. Projeto deve resultar de um estudo funcional e técnico do problema

C. Racionalização das circulações e agrupamento de usos e atividades afins

D. Auxilio na prevenção à infecção hospitalar

E. Flexibilidade dos ambientes

F. Preocupações com o conforto ambiental

F.1. Conforto térmico

F.2. Conforto visual

G. Presença de verde

H. Relação interior $x$ exterior

I. Humanização dos espaços

3.6.2 Críticas

3.7 Relação arquitetura x humanização 


\section{Capítulo 4}

Arquitetura e humanização na prática hospitalar

4.2 Hospital do câncer de barretos

4.3 Santa casa de porto alegre

4.4 Santa casa de são joao da boa vista

\section{Capítulo 5}

Abordagens teóricas $x$ análises práticas: a humanização entre a teoria e a prática 145

5.1 Valorização do "olhar diferenciado" do utente

5.2 Sob a ótica da legislação

5.3 Valorização dos profissionais da saúde

5.4 Valorização dos espaços pela arquitetura

5.4.1 Adequação ao local

5.4.2 Projeto deve resultar de um estudo funcional e técnico do problema

5.4.3 Racionalização das circulações e agrupamento de usos e atividades afins 164

5.4.4 Auxilio na prevenção à infecção hospitalar

5.4.5 Flexibilidade dos ambientes

5.4.6 Preocupaç̃̃es com o conforto ambiental

5.4.7 Presença de verde

5.4.8 Relação interior $x$ exterior

5.4.9 Humanização dos espaços

\section{Capítulo 6}

Conclusão

Referências bibliográficas 
Capítulo 1

Contextualizando a Humanização 
A questão da saúde pública é um assunto bastante abrangente e amplamente discutido não só na área da Arquitetura como também em outras áreas, como a médica, área da enfermagem, área da administração pública ou privada, etc. O que nos chama inicialmente a atenção, é o fato de o termo humanização estar cada vez mais presente nas discussões, tanto teóricas quanto práticas, das áreas que envolvem a saúde no país. Entender os aspectos que de alguma maneira envolvem a questão da humanização parece, ao menos por enquanto, bastante pertinente para um olhar contemporâneo sobre a saúde pública e a arquitetura hospitalar.

Um olhar atento e interessado aos jornais, revistas, mídia digital, além de pesquisas nos registros de seminários das áreas de saúde ou mesmo nas políticas públicas relacionadas à área da saúde, indica uma clara preocupação com a humanização dos espaços e serviços de saúde no Brasil.

O projeto em questão objetiva entender essa atual tendência e saber qual o papel, a importância e a pertinência da arquitetura na humanização dos espaços assistenciais de saúde no Brasil, levantando as práticas e os processos que vêm sendo adotados, visando possibilitar, desta forma, uma melhor assertividade e eficácia da arquitetura nos projetos para estabelecimentos hospitalares.

Assim, espera-se contribuir para a reflexão teórica e acadêmica sobre o papel da arquitetura na humanização dos ambientes hospitalares, buscando auxiliar também na reflexão sobre a prática dos arquitetos que trabalham na elaboração e execução de projetos de edificações para o atendimento à saúde no país, tanto públicos como privados.

O tema colocado pode ser considerado não apenas de interesse discursivo mas, antes, também absolutamente relevante do ponto de vista da prática em arquitetura. Partindo-se do princípio que a arquitetura deve se voltar para o ser humano - enquanto aquele que usufrui de seus objetos, o edifício e a cidade -, o que mais se constata na abordagem de pesquisa aqui proposta é que a arquitetura voltada para os espaços assistenciais de saúde é uma arquitetura pensada e feita para o ser humano talvez em sua condição de maior sensibilidade.

No $1^{\circ}$ Seminário de Arquitetura Hospitalar, realizado em agosto de 2003, na cidade de São Paulo, 
com o apoio da revista Projeto e Design, os temas humanização e flexibilidade dos ambientes foram o principal assunto. Arquitetos de reconhecida competência na área, como Jarbas Karman, Augusto Guelli, Carlos Eduardo Pompeu, Siegbert Zanettini e Lauro Miquelin foram os principais palestrantes.

Como evidenciou Carlos Eduardo de Pompeu, por exemplo, "o hospital tem de ser bom e parecer bom para dar a sensação de confiança" $a^{\prime \prime}$. Lembra também que médicos norte-americanos já constataram que o psiquismo é fator determinante para a rápida recuperação do paciente: "nosso psiquismo pode ser motivado ou deprimido e isso é regulado em grande parte pelas emoções."

Já o arquiteto Siegbert Zanettini, lembrou que a sensibilidade tem importante papel em qualquer projeto elaborado pelo arquiteto. Porém, no caso de ambientes hospitalares, maior atenção deve ser dada para garantir um certo equilíbrio entre os elementos e garantir um espaço mais humanizado.

O termo humanização é de difíil definição mas, tomando como simples exemplos os conceitos citados acima, talvez se comece a entender que qualquer espaço exerce influência sobre o ser humano, seja este sua residência, seu local de trabalho, de lazer etc. O que torna estes espaços humanizados é o fato de estabelecerem uma forte e significativa ligação com o seu usuário. No caso dos ambientes hospitalares, este aspecto deve ser mais forte ainda pois, os espaços são projetados para receber pessoas geralmente em estágio de recuperação no qual o fator emocional muito influi. Sendo assim, o ambiente deve propiciar ao indivíduo sensação de bem-estar e tranquilidade, que consequentemente Ihe darão a sensação de segurança e confiabilidade.

Se a definição não é imediata, é importante esclarecer que o termo humanização em nenhum momento deve ser confundido com luxo, mas sim com qualidade.

Móveis, decoração, equipamentos eletrônicos, por si sós, não garantem qualidade ao ambiente. O conjunto todo é que garante isso e não necessariamente um fator está ligado ao outro.

Deve se partir da compreensão que humanização é o conceito que dá ao ambiente a garantia de que ele influenciará no ser humano que o utilizar de maneira benéfica, acelerando, assim, suas condições de melhora.

Tal garantia se consegue por intermédio de vários fatores, como iluminação, ventilação, utilização correta de cores, mobiliário, sensação de segurança, além de tantos outros fatores.

O fator luxo ou o serviço de hotelaria, por exemplo, pode até ser um fator auxiliar para garantir ao espaço melhor qualidade, mas jamais será o mais importante ou o fator determinante.
Outro fator determinante para obtenção de qualidade do ambiente é a escolha dos materiais a serem empregados na obra. Atualmente há uma variedade de opções de materiais, que permitem garanti grande eficiência aos ambientes, tanto no quesito humanização, quanto no quesito tecnológico. Sabe-se que os ambientes hospitalares têm a necessidade de grande capacidade de adaptação flexibilidade e adequação às novas técnicas da medicina, que vêm evoluindo constantemente. Unir a tudo isso o conceito de humanização é o grande desafio do arquiteto projetista, atualmente. Grandes exemplos de sucesso neste aspecto podem ser observados nos trabalhos de Lelé (João Filgueiras Lima) e em outros hospitais que seguem sua linha de desenvolvimento.

A grande procura e demanda pelo assunto atesta o crescimento e a pertinência das questões relativas ao cuidado especializado no tratamento técnico dedicado ao projeto e à construção de espaços hospitalares mais humanizados. Outros inúmeros congressos voltados à humanização hospitalar inclusive em diferentes áreas de atuação profissional - como as da administração hospitalar medicina, enfermagem etc -, vêm acontecendo com bastante frequência.

Por exemplo, o Congresso Humanização Hospitalar em Ação, realizado em São Paulo, no ano de 2007, em sua quinta edição, começou no Brasil pela iniciativa de ONG’s e de profissionais da saúde determinados a humanizar os ambientes hospitalares e teve como apoio de conteúdo o Hospital das Clínicas (FMUSP), a instituição Doutores da Alegria e o Projeto Carmim. O Congresso Brasileiro de Enfermagem, em sua quinquagésima sétima edição, realizada no ano de 2005 na cidade de Goiânia, discutiu a importância da participação do profissional enfermeiro junto à equipe de desenvolvimento dos espaços com o objetivo de garantir melhores resultados e qualidade aos ambientes. 0 'enfermeiro' é um dos personagens mais importantes no tratamento do paciente, podendo em muito contribuir no aspecto da humanização.

Em evento promovido pelo Fórum da Construção, uma organização vinculada à arquitetura e construção civil, em dezembro de 2006, na cidade de São Paulo, o seminário "Arquitetura Hospitalar na Atualidade" contou também com a participação de diversos profissionais da área de arquitetura e alguns arquitetos considerados referenciais na área, como por exemplo, o arquiteto Jarbas Karmman. O enfoque principal foi a discussão sobre as tendências na arquitetura hospitalar e a preocupação com a humanização e eficiência do atendimento. Já a oficina "HumanizaRio", realizada em julho de 2007 na cidade do Rio de Janeiro, coordenada pelo Instituto Nacional do Câncer (INCA), abordou especificamente a questão da humanização em espaços dedicados aos cuidados com a saúde no Estado do Rio de Janeiro e à Política Nacional de Humanização Hospitalar (PNH).

Os Congressos Nacionais da ABDEH - Associação Brasileira para o Desenvolvimento do Edifício Hospitalar - geram discussões e artigos que tratam diretamente do assunto, como, por exemplo os 
artigos: A Humanização e o ambiente Físico Hospitalar; e O Invisivel de Quem Cuida: a humanização das unidades de apoio em ambientes de saúde - uma experiência em Juiz de Fora, Humanização nos Espaços Hospitalares Pediátricos: A qualidade do espaço construído e sua influência na recuperação da criança hospitalizada, ou mesmo o artigo A Cor no Ambiente Hospitalar, entre outros.

Os cursos de especialização, como o curso de especialização de arquitetura em sistemas de saúde da Universidade Federal da Bahia, também abordam a questão da humanização, como ilustra a monografia Humanização do Espaço Arquitetônico em Unidade de Hemodiálise, entre outros.

Todas essas produções que vêm sendo geradas nos últimos anos, acabam por fazer com que a bibliografia recente sobre o assunto aborde de maneira mais constante a questão da humanização do atendimento e também dos espaços assistenciais de saúde.

Há também iniciativas que partem do setor privado de saúde. Em um encontro nacional da UNIMED, uma das mais conhecidas cooperativas de prestação de serviços médicos do país, também são identificadas preocupações com a discussão sobre "humanização hospitalar". Tal discussão, neste caso, pode decorrer mais da demanda de mercado que propriamente da necessidade de melhoria do atendimento, o que pode ser preocupante, pois a qualidade do atendimento e espaços humanizados em discussão, deixam de ter seu caráter crítico e passam a ter um caráter mercadológico, o que apenas pode denotar um caráter comercial sem preocupação com os aspectos da humanização Inclusive a própria iniciativa pública através de seus planos de humanizaç̃ão do atendimento nos estabelecimentos assistenciais de saúde públicos, através de políticas como o HumanizaSUS (Política Nacional de Humanização), que é uma política nacional claramente focada nesta questão, tem demonstrado esta preocupação.

Uma segunda análise sobre o tema da Arquitetura no processo de Humanização dos Ambientes Hospitalares destina-se a entender se tal abordagem é ou não uma questão importante para a arquitetura. Através da pesquisa, pôde-se entender melhor, por exemplo a questão voltada para a legislação específica da área ou a correta especificação de materiais e tecnologias, entender as atuais e futuras abordagens projetuais da arquitetura.

Ainda, analisando-se o efetivo papel da Arquitetura no processo de Humanização dos Ambientes Hospitalares, entender também claramente a relação dela, arquitetura, com outras disciplinas e o que esta relação pode trazer de benefícios, ou seja, compreender que outro olhar desta abordagem pode contribuir para a arquitetura. 
Capítulo 2

Percursos

Metodológicos 


\subsection{Definição do objeto de estudo}

O assunto em questão oferece uma vasta gama de opções de enfoque de pesquisa. Pode-se tanto buscar estudar elementos singulares como a utilização das cores nos ambientes, até questões complexas que envolvem ambientação, implantação e relação com o entorno.

Estudar ambientes específicos como as enfermarias, os corredores, as salas de espera, as salas de procedimentos, centros de tratamento intensivo entre tantos outros, é outra possibilidade que também abre uma variedade de opções de estudo.

A abordagem pretendidaé olhar a questão da humanização dos ambientes em ambientes assistenciais de saúde, que visem ao atendimento público. No setor público porque permitirá olhar a situação no "ambiente" mais difíil. Já no hospital privado há mais alternativas e recursos a serem utilizados, como investimentos em hotelaria, decoraç̃̃es mais luxuosos, equipamentos mais modernos, etc. Inicialmente se entende que os ambientes assistenciais de saúde públicos, são mais carentes de uma maneira geral. Ao mesmo tempo que têm um maior volume de utentes quando comparados aos estabelecimentos privados, são estabelecimentos que têm maior deficiência em inúmeros aspectos, principalmente quando se fala em recursos financeiros, o que faz com que busquem e dependam de campanhas de arrecadação de verbas, doações entre outras situaç̃̃es que muito dificultam sua administração, pois o administrador tem que cuidar de recursos com as quais nem sempre pode contar e pior, independem de sua administração para existirem ou não.

Assim, o objeto de estudo constitui-se, portanto, no ambiente assistencial de saúde voltado para o atendimento ao público do Sistema Único de Saúde, que permita estabelecer um panoramageneralizado da situação da humanização nestes espaços, panorama este que será analisado e comparado com a abordagem teórica sobre o tema para se entender realmente sua eficiência, se ela existir. 


\subsubsection{Humanização sob a perspectiva do utente}

O utente pode passar nos estabelecimentos assistenciais de saúde desde poucos minutos até anos, dependendo de sua enfermidade e recuperação. Ele pode frequentar estes estabelecimentos para um procedimento eventual, como um exame ou um atendimento de urgência; ele pode frequentar estes estabelecimentos de maneira mais constante para realizar procedimentos que necessitam de maior frequência, como, por exemplo, procedimentos de hemodiálise ou radioterapia para os quais o paciente comparece a estes estabelecimentos algumas vezes por semana; ele pode necessitar ficar internado por um período pequeno de tempo que dura um ou poucos dias para se recuperar de uma doença ou procedimento de baixa complexidade e até mesmo ele pode precisar se internar nestes estabelecimentos por longos períodos em função de doenças ou procedimentos mais complexos.

Em qualquer uma dessas situações, o indivíduo que passa a ser considerado utente, é retirado de sua rotina natural da vida e passa a ter momentos que envolvem sentimentos de angústia, medo, incerteza, insegurança, desconforto, abandono, etc. São, estes sentimentos que tornam o utente um ser fragilizado.

Quando fragilizado, tudo que se passa para ele ou mesmo tudo que ele vê, vê com um olhar diferente. É exatamente neste aspecto de olhar diferenciado que os estabelecimentos assistenciais de saúde têm que se focar para garantir a este utente uma melhor qualidade em seu tratamento e recuperação, qualidade que não pode ser vista de maneira superficial pois, qualidade nos Estabelecimentos Assistenciais de Saúde, envolve desde a qualidade primária que garante salubridade, segurança e conforto mínimo até a qualidade que vise garantir a este indivíduo uma melhor condição de recuperação, tornando assim melhor sua permanência nestes ambientes e, dentro do possível, de menor duração pois, o objetivo destes estabelecimentos é o de curar o utente e devolvê-lo a sua vida normal, no menor tempo possível.

\subsubsection{Humanização sob a perspectiva da equipe de atendimento}

Inicialmente deve-se entender o utente como o personagem principal dos estabelecimentos assistenciais de saúde, por isso tudo deve ser voltado para ele. O utente está presente nestes locais para se tratar e se curar, preferencialmente no menor tempo possível, precisando de cuidados especiais, de atendimento especial. Mas, para tudo isso acontecer na prática, uma série de outros usuários precisam estar presentes e atuantes. Estes outros usuários constituem a equipe de atendimento ou como o Ministério da Saúde chama, os trabalhadores da saúde, compreendendo desde os funcionários de apoio como recepcionistas, faxineiros, cozinheiros, etc, passando por funcionários administrativos até se chegar à categoria que atua diretamente com o utente, que é a equipe clínica dos estabelecimentos, formado por enfermeiros, psicólogos, fisioterapeutas e médicos que são os maiores responsáveis pelos procedimentos e, consequentemente, pela recuperação e tratamento dos utentes.

Enquanto o utente chega a passar grandes períodos internado ou mesmo frequentando de maneira sistemática tais estabelecimentos, estes trabalhadores da saúde, passam, na verdade, 0 tempo todo dentro destes ambientes. Para que eles possam se preocupar com os utentes e assim garantir seu melhor tratamento, estes ambientes precisam ser preparados e organizados também para garantir as melhores condições de conforto a eles também. Abordagens recentes já focam esta questão. Por exemplo, o artigo "O Invisível de Quem Cuida", gerado a partir do I Congresso Nacional da ABDEH - IV Seminário de Engenharia Clínica - 2004, trata da humanização das "áreas pouco visíveis" dos Estabelecimentos Assistenciais de Saúde - EAS, no caso, especificamente as lavanderias hospitalares.

Ainda, segundo GOLDENSTEIN, com base numa pesquisa prévia com usuários e funcionários em um hospital, trabalhando a modificação dos ambientes como pintura, iluminação, mobiliário, etc. nota-se modificações comportamentais:

Destado de ânimo tanto dos pacientes quanto das equipes de saúde; percepção por parte dos pacientes, de uma melhor atenção para com eles; aumento da ocupação dos espaços públicos, entre outras. ${ }^{3}$

A legislação em vigor, já cuida para que os ambientes de trabalho ofereçam a maior condição de segurança aos procedimentos, mas cuidado especial deve ser dado também aos ambientes de apoio destinado a estes profissionais da saúde, como as áreas de conforto médico, os refeitórios, as áreas de permanência em geral, entre outros.

\subsection{Definição do corpus}

A escolha dos hospitais a serem estudados, tem como principal parâmetro a proximidade com o trabalho, quer seja ela física, quer seja ela emocional. Proximidade física relacionada à cidade de São Carlos e São João da Boa Vista, cidades onde se desenvolve esta pesquisa e cidade de residência respectivamente. Proximidade emocional explicada pela experiência de sucesso vivida, experiência esta que em muito motivou a escolha deste tema para ingresso no programa de mestrado. Mais, experiência que coloca uma vivência prática que certamente beneficia a pesquisa.

Além desta proximidade, outro aspecto que foi analisado, foi a busca por se conseguir, dentro das possibilidades, hospitais de portes físicos diferentes, de forma a permitir um melhor entendimento 
nos diferentes contextos práticos. Somada a esta diferença de porte físico, também buscou-se por estabelecimentos de diferentes complexidades e finalidades em seu atendimento.

Os hospitais selecionados foram: o Hospital Escola Municipal de São Carlos, que atualmente encontrase somente com sua primeira etapa da obra concluída, ou seja, oferece somente atendimento ambulatorial de urgência e emergência a utentes e exames radiológicos. Desta forma, não oferece ainda nenhum leito de internação, nem executa procedimentos de maior complexidade; o Hospita do Câncer de Barretos, que oferece 80 leitos de internação, além de uma ala de atendimento ambulatorial que realiza anualmente mais de 450.000 procedimentos de baixa e alta complexidade; o complexo da Santa Casa de Porto Alegre que, apesar de seus 200 anos de existência, de oferecer mais de 1000 leitos de internação e contar com sete hospitais, sendo seis deles especializados, pode ser considerado atualmente um hospital de referência, tanto no atendimento aos usuários do SUS, quanto com relação à qualidade do tratamento oferecido. Referência esta que sai do âmbito do Estado do Rio Grande do Sul e abrange o nível nacional de referência; e a Santa Casa de São João da Boa Vista, que oferece aproximadamente 160 leitos de internação e, de certa forma constitui-se em um centro regional para as cidades adjacentes de pequeno porte que não possuem hospital. Além disso, existe há mais de 100 anos o que oferece à pesquisa um melhor entendimento da evolução e porque realiza procedimentos de alta complexidade.

Desta maneira, através destas análises práticas busca-se um embasamento das visões que permita um melhor entendimento e consequentemente, uma análise consistente. Não se opta aqui por estudo de caso destas instituições por se entender que um estudo de caso que forneça insumos mais aprofundados para a pesquisa de uma instituição, contribui para o objetivo deste trabalho menos que a análise mais geral de vários estabelecimentos.

\section{Estabelecimentos Selecionados:}

\section{Hospital Escola Municipal de São Carlos}

Hospital ainda em construção porém com sua primeira etapa de obras concluída e em funcionamento. Dois motivos foram os principais para sua escolha como estabelecimento a ser estudado: primeiro pelo fato de estar instalado na cidade de São Carlos; segundo por ser um hospital projetado por Lelé - João Filgueiras Lima.

Além disso, o Hospital Escola Municipal de São Carlos é um hospital já em funcionamento porém ainda sem a ala destinada à internação. Fato este que o coloca como o menos complexo a ser estudado pois oferece somente atendimento de emergência, ambulatórios para adultos e pedítricos e setor de exames radiológicos. Ou seja, é um estabelecimento de pequeno porte físico e baixa complexidade nos procedimentos oferecidos ao público.
Quando estiver com todas suas etapas de obra conclúidas, terá área aproximada de 30.000 metros quadrados e tem pretensão de ser referência no atendimento aos usuários do Sistema Único de Saúde (SUS). Além disso, é um hospital que visa a integrar a rede de saúde pública à rede escola-pesquisa através da Universidade Federal de São Carlos - UFSCAR, que será responsável por sua administração.

Hospital do Câncer de Barretos

O Hospital do Câncer de Barretos está localizado na cidade de Barretos, região de São José do Rio Preto, a aproximadamente $190 \mathrm{~km}$ de distância de São Carlos. É um hospital especializado no tratamento contra o câncer e nacionalmente conhecido até em função de seus pavilhões receberem nomes de artistas populares

O principal motivo de sua escolha como objeto de estudo é o fato de o Hospital do Câncer de Barretos ser referência na qualidade do atendimento ao público usuário do Sistema Único de Saúde - SUS (praticamente 100\% do volume dos utentes) e qualidade do tratamento especializado.

Éum hospital de pequeno porte físico, contém inclusive, apenas 80 leitos de internação. Embora tenha somente 80 leitos disponíveis para internação, sua capacidade de atendimento é alta pois, em função de o tratamento contra o câncer poder ser feito através de procedimentos que não demandem efetivamente internaç̃os. Por exemplo, no ano de 2008 foram realizados mais de 450.000 atendimentos para mais de 84.000 pacientes de 27 estados brasileiros com uma média aproximada de 3000 atendimentos ambulatoriais por dia.

\section{Santa Casa de Porto Alegre}

A Santa Casa de Porto Alegre é um complexo de sete hospitais e atualmente é o maior hospital do Rio Grande do Sul. Seus hospitais englobam deste os procedimentos gerais até os especializados como Hospital oncológico, neurológico, de transplantes, entre outros. Todos os sete hospitais são considerados de alta complexidade contendo cada um sua própria Unidade de Tratamento Intensivo (UTI) e centro cirúrgico.

O complexo oferece no total mais de 1000 leitos de internação sendo 60\% deles destinado aos usuários do Sistema Único de Saúde (SUS). Além disso, é considerado referência em qualidade de atendimento no Estado, qualidade esta comprovada pelas consecutivas obtenções de bons resultados nas pesquisas de qualidade do SUS e referência nacional em qualidade técnica em diversas especialidades, como neurologia, pneumologia e transplantes de órgãos.

Os dois maiores motivos que levaram esta pesquisa a selecionar este complexo como objeto de estudo foram primeiramente o fato de uma experiência pessoal nele vivida há alguns anos (2003/2004), que conforme colocado, oferece uma vivência que contribui com a pesquisa e em segundo lugar por ser o complexo referência na qualidade de atendimento, qualidade que, pela experiência vivida, de antemão já se comprova 
Santa Casa Dona Carolina Malheiros de São João da Boa Vista

A Santa Casa de São João da Boa Vista, é um hospital de médio porte e considerado de alta complexidade, que atende toda a região de São João da Boa Vista. Nela há 156 leitos para internação sendo 70\% destinados ao Sistema Único de Saúde (SUS), há centro cirúrgico, maternidade e Unidade de Tratamento Intensivo (UTI).

Este hospital caracteriza-se por ser o retrato da Santa Casa tradicional, voltada para atendimento preferencial da população local, onde trabalham os médicos com forte ligação com a cidade, geralmente com dedicação de praticamente toda a vida profissional e assim como as Santas Casas em geral, atravessa sucessíveis crises inclusive financeiras, que hora ou outra colocam a instituição em dificuldades de manutenção e sobrevivência.

O principal motivo pela sua escolha como objeto de estudo, é o fato de ser também o hospital da cidade de residência do pesquisador, o que impõe estreitos laços de ligaç̃o e entendimentos pois nela já fora internado algumas vezes, além dos inúmeros comparecimentos para procedimentos simples ou simplesmente como mero acompanhante de algum utente. Sendo assim, da mesma forma que o estabelecimento anterior, oferece ao trabalho uma vivência prática que proporciona insumos eficientes para a pesquisa.

Desta maneira, através destes quatro objetos de estudo, busca-se fechar um panorama de análise que visa estudar estabelecimentos de baixa, média e alta complexidade e de pequeno, médio e grande porte físico, o que muito embasa as visões deste estudo.

\subsection{Hipótese}

Inicialmente, aparentemente a questão da humanizaç̃ão dos ambientes parece dividida, no olhar da arquitetura, em dois grandes eixos: o primeiro que privilegia mais as questões voltadas para decoração, hotelaria, luxo; o segundo só tem os requisitos básicos (adequação ao local, projeto deve resultar de um estudo funcional e técnico do problema, racionalização das circulações e agrupamento de usos e atividades afins, auxilio a prevenção à infecção hospitalar, flexibilidade dos ambientes, preocupações com o conforto ambiental, presença de verde, ralação entre interior e exterior e humanização dos espaços) de uma arquitetura voltada pra a humanizacão, que são desprovidos de decoracão, luxo, etc. para garantir sua eficiência.

A primeira linha, mais voltada para a questão da decoração, luxo, etc. naturalmente é voltada para um público mais selecionado que por esse diferencial pode pagar, através de tratamentos particulares ou mesmo através de convênios de saúde.

A segunda linha de raciocínio, quando coloca os requisitos básicos, entre outros coloca as questões voltadas para conforto térmico e acústico, relação entre interior e exterior, presença de paisagismo, utilizaç̃o adequada de cores, etc como elementos que garantam aos ambientes uma boa qualidade e consequentemente boa influência sobre os indivíduos que frequentam tais ambientes.

Tal linha não exclui necessariamente o uso de uma decoração mais privilegiada ou mesmo um certo grau de sofisticação em seus ambientes. O que precisa ficar claro é que tais elementos devem ser vistos como elementos acessórios e que não garantem necessariamente a qualidade do ambiente. Deve-se buscar a qualidade através de elementos básicos (requisitos) e após alcançado tal objetivo, sofisticá-lo ou não.

O que existe muito atualmente, são ambientes onde os elementos aqui colocados como sofisticados acabam por compensar a falta dos tais requisitos básicos, como por exemplo, uma climatização artificial para corrigir falta de eficiência na ventilação ou não correta implantação e insolação, esquadrias com alta tecnologia para garantir vedaç̃o contra ruídos externos gerados por uma adequaç̃o ao local não eficiente ou mesmo para resolver o problema de insolação em excesso, entre outras situações possíveis como claramente comenta TOLEDO: As tentativas de humanização do atendimento hospitalar podem ser encaradas como uma primeira reação à hegemonia do hospital tecnológico e vêm sendo levadas a efeito com diferentes graus de profundidade e abrangência. ${ }^{4}$

A hipótese é a de que em hospitais de atendimento ao públicos há preocupação com a questão da humanização dos ambientes mas, em função da menor disponibilidade de recursos, esta preocupação se volta exclusivamente para os princípios essenciais da humanização - os requisitos básicos. Estes princípios por si só já são suficientes para garantir um nível adequado de qualidade arquitetônica no ambiente hospitalar. relativamente à humanização.

\subsection{Objetivo}

Como objetivo principal, busca-se entender se a preocupação com a questão da humanização dos ambientes existe nos hospitais que visam ao atendimento público e, em ela existindo, saber se é, de fato eficiente. Entender se, em tais hospitais, a presença da arquitetura voltada para os requisitos básicos, aquela que se preocupa com ventilação eficiente, iluminação eficiente, presença de verde (paisagismo), relação entre interior e exterior dos ambientes, etc. é eficiente na humanização dos ambientes hospitalares.

Como objetivos secundários, busca-se primeiramente mapear quais são os requisitos básicos utilizados nos hospitais voltados para o atendimento ao público e que serão estudados; em segundo lugar, fornecer elementos e subsídios para o desenvolvimento de projetos arquitetônicos hospitalares dos Estabelecimentos Assistenciais de Saúde voltados para a humanização, bem como trabalhos na área que visem a esta questão. 
Capítulo 3

Arquitetura e Humanização: Abordagens Teóricas 


\subsection{Utente}

Em termos de humanização dos ambientes hospitalares, antes de se analisar qualquer questão relacionada à arquitetura, é de fundamental importância entender-se que um dos elementos mais importante de todo o conjunto é o utente e que tudo que se objetiva fazer em relação à qualidade do atendimento, da arquitetura, de recursos de segurança etc., é voltado para o utente. Ele tem que ser o foco principal da análise: qualquer argumento analítico que o deixe de lado, será inócuo e em nada contribuirá para uma discussão consequente sobre a qualidade aos ambientes.

Analisando a evolução histórica das características dos ambientes assistenciais de saúde, vê-se uma constante transformação no conceito de utente. 0 utente deixou de se instalar nesses ambientes para morrer, como nas chamadas "salles de mourir", para se colocar em ambientes que têm como objetivo tratá-lo, curá-lo e trazê-lo rapidamente de volta ao exterior, como claramente coloca BITTENCOURT:

O hospital passou a ter uma função terapêutica, deixando de ser um lugar terminal para o doente. transformando-se num obieto de preocup diretamente relacionada às suas propriedades 5

Hospital é, hoje, o local onde se internam e se tratam doentes, ou seja, o local agrega, com o tempo, a "função terapêutica", função que foi adquirindo com a evolução dos métodos da medicina. Atualmente, a preocupação da medicina ultrapassa o objetivo terapêutico, alcançando, além da função de recuperar a saúde do paciente, também a preocupação com a qualidade desta recuperação, para a qual contribui, de modo determinante, a qualidade de vida durante a internação, bem como no tempo que ela dura e na influência que ela exerce sobre os acompanhantes dos pacientes - que muito contribuem nessa recuperação. CARPMAN, deixa este argumento bastante claro, como citado a seguir

De acordo com Carpman, Grant e Simmons (1986 apud MEDEIROS; LUCIANA DE, 2004, p. 44), um projeto humanístico de arquitetura deve contemplar o ponto de vista de pacientes e visitantes. Para alcancar esse fim arauitetos e demais planejadores devem considerar a internaç̃o das pessoas com seus ambientes e consequentement 
ao serem submetidos a algum procedimento e ao entrarem em contato com adversidade/quantidade de aparatos e pessoas presentes no local. Segundo os autores, as necessidades dos pacientes e visitantes

são levadas em conta quando aspectos são obedecidos: sinalizaç̃ão, conforto físico, possibilidade de regular o contato social e cuidado com o significados transmitidos pelo ambiente ${ }^{6}$

Pode-se então, concluir que, de modo geral, sem vínculo especial com determinadas enfermidades ou mesmo com o tipo de hospital, a evolução do modo como se compreende os ambientes hospitalares pode ser resumido na seguinte sequência: local para tratamento dos doentes > ambiente para o tratamento e recuperação dos utentes > e, atualmente, ambiente dedicado ao tratamento e recuperaç̃o dos utentes com a maior qualidade e em menor tempo possível.

Há, ainda hoje, estabelecimentos de saúde voltados para os pacientes terminais, como, por exemplo, os hospitais especializados no tratamento oncológico. Obviamente, nem todos têm esta finalidade e sim a terapêutica, mas os que tem. buscam transformar estes momentos finais em instantes menos dolorosos, tanto para os utentes quanto para seus acompanhantes.

Vale citar importante observação de GHEZZI, na qual o autor explica, de maneira bem clara, o porquê da denominação paciente, aqui sempre colocado como utente, ao indivíduo doente que se interna nos hospitais:

O termo paciente é empregado tanto pela enfermagem como pelos médicos com justificada propriedade. uma vez que recebe a ação praticada por um agente, ou ainda a pessoa doente, sob cuidados médicos. ao invés da palavra doente, que quer dizer apenas pessoa que tem doençą ${ }^{7}$.

Por outro lado - e de uma forma geral -, os ambientes assistenciais de saúde evoluíram e continuam evoluindo em função do constante desenvolvimento das técnicas e equipamentos médicos que geralmente condicionam as inovaç̃̃es arquitetônicas, associando evolução tecnológica ao maior conforto do utente:

Segundo Devlin e Arneill (2003 apud MEDEIROS; LUCIANA DE, 2004, p.57), a evolução do hospital e sua nova imagem modificada pelas tecnologias e humanização dos espaços gerou o aparecimento de edifícios que primam pelo conforto do paciente ${ }^{8}$.

Tomando como exemplo o conforto luminoso, embora tenha sido objeto de constante aprimoramento projetual - tanto no que se refere à iluminação natural quanto à artificial -, com a evolução dos equipamentos e dos sistemas luminotécnicos, faz-se necessária a constante pesquisa para um aperfeiçoamento cada vez maior das condicõos de sua aplicacão, tendo em vista a necessidade de concebê-los conforme as demandas de conforto luminoso do paciente - e não mais como recurso que atende exclusivamente às demandas dos procedimentos e cuidados médicos. O mesmo acontece em relação ao conforto térmico, visual, acústico, à ventilação natural, à ventilação artificial etc, conforme mostram CORBELLA \& YANNAS e SAMPAIO nas citações abaixo:

Com relaç̃o ao conforto visual, além da quantidade de luz ter que ser adequada para que a realização de tarefas visuais aconteça de maneira satisfatória, é fundamental que não haja ofuscamento (..) nem grandes

O conforto acústico está relacionado com a qualidade do som produzido no ambiente, ou seja, se esse som produzido é audível satisfatoriamente pelos seus ocupantes, e com a não interferência de rúdos

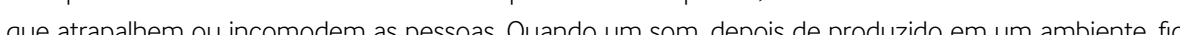
que atrapalhem ou hcomodem as pessoas. Quando um som, depois de produzido em un ambiente, fica

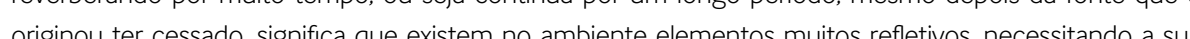
onginou ter cessado, signica que existem no ambente elementos mulos rentelvos, necessitando a su substituição por elementos mais absorventes para que haja uma maior satisfação e sensação de bemestar. Se rúdos externos interferem nas atividades desenvolvidas em um ambiente, um melhor isolamento acústico como o aumento da massa do fechamento ou o amortecimento através de um material que diminui o impacto na superficie onde ocorre o ruído pode ser eficaz ${ }^{10}$.

Embora atualmente encontrem-se disponíveis inúmeras ferramentas e sistemas tecnológicos para garantir a eficiência desses ambientes em relação aos utentes que abrigam, há, contudo, algumas preocupações que se remetem às premissas de projeto: alguns recursos de projeto que lidam com aspectos mais amplos, recursos projetuais não esquecidos por grandes arquitetos - como Rino Levi. Lelé (João Filgueiras Lima) e outros -, e que não podem deixar de ser considerados para se obter uma perfeita adequação dos resultados. Pode-se citar, por exemplo, o estudo cuidadoso da implantação do edifício, estudo de fluxos, estudo funcional e técnico do problema, flexibilidade da construção criação de espaços verdes "...flexibilidade das instalaç̃os, padronização de elementos da construção e iluminação natural e conforto térmico, entre outros."1"

A constante evolução nas técnicas e dos equipamentos médicos parece fazer com que a preocupação com a humanização seja cada vez maior. Pode-se perceber esta preocupaç̃o, por exemplo, na Política Nacional de Humanização (PNH), promovida pelo Ministério da Saúde desde o ano de 1998, articulada em planos de voluntariado como os "Doutores da Alegria", que têm grande repercussão nos meios de comunicação e mesmo nos filmes acessíveis à população como um todo, como a película americana "Path Adams: 0 Amor é Contagioso", que fala sobre tratamentos mais humanos para os pacientes de um hospital dos Estados Unidos. Tais exemplos mostram que é comum a preocupação com a Humanização dos ambientes hospitalares - que não se trata apenas de uma preocupação só com o espaço, mas também com o atendimento e com o preparo dos médicos e enfermeiros. Também fica claro, principalmente no exemplo do "Doutores da Alegria", que a tão buscada humanização hospitalar 
está acontecendo, nestes casos, por iniciativas próprias de grupos voluntários, sem necessariamente a intervenção direta do poder público - que apenas respalda a iniciativa. O que é importante salientar é que a humanização hospitalar tem que atender a estes três aspectos, de modo concomitante: promocão de melhorias técnicas nos ambientes construídos, melhorias nas suas condições de uso e instalação e no melhor preparo dos profissionais de atendimento.

\section{A preocupação com a Humanização existe - e isto está bastante claro.}

Ainda, algumas iniciativas vêm sendo tomadas, ou por grupos voluntários isolados ou, ainda, pela iniciativa privada. No caso da iniciativa privada, o preocupante é que a tão buscada melhoria na qualidade do atendimento e humanização dos espaços é encarada como um diferencial de marketing. Portanto, a humanizaç̃o não é encarada como busca pela melhoria na recuperaç̃o do paciente, mas como artifício e argumento de venda ou então, muitas vezes, confundida com luxo ou melhores serviços de hotelaria: "... existe uma tendência em comparar a estrutura de determinados hospitais à de hotéis, atribuindo-thes a qualidade de 'humanizado' devido à variedade das opç̃oes de serviço de conforto oferecido ao paciente" ${ }^{\text {"12. }}$.

O fato é que a preocupação com a humanização dos ambientes hospitalares faz-se inequivocamente presente, independentemente do fato de estar ou não sendo operacionalizada e transformada em ações.

Nos seminários e congressos de arquitetura hospitalar - como a / e // Semana de Arquitetura Hospitalar, realizadas em 2005 e 2006 pela revista PROJETO DESIGN -, o assunto sempre esteve em pauta. Conforme a manifestação de renomados arquitetos nesta área - como João Carlos Bross, Jarbas Karman ou Siegbert Zanettini, que atualmente são referências na área de projetos e construções hospitalares -, o assunto aparece como uma constante preocupação.

Os hospitais são comumente vistos como locais de doença - e não de saúde. É isso que lhes conforma o caráter e também, forçosamente, caracteriza seu usuário como um utente: alguém que sofre a intervenção de um agente externo que Ihe administra uma ação terapêutica. Só este fato já é suficiente para desencadear um quadro de estresse que agrava as condições físicas e psicossomáticas do utente. Daí a importância de um projeto humanizado, que alivie sua angústia. Com ele, o objetivo deveria ser o de criar espaços saudáveis, que tragam sensação de bem-estar e proporcionem boa relação entre o ser humano e o meio. Essas metas podem ser alcançadas, dentre outras formas, com a ajuda de uma série de recursos projetuais como, por exemplo, implantação adequada, boa dosagem de aberturas protegidas e com insolação adequadamente dimensionada projeto paisaǵístico, recursos da psicodinâmica da cor, considerando até mesmo diferenças de sexo e idade, como coloca CAPMAN:
CAPMAN et al.(1986 apud SAMPAIO, ANA VIRGINIACARVALHÃES DE FARIA, p. 198) fazem recomendaçōes com relação às áreas externas. Se possível, todos os ambientes devem ter acessos a áreas sombreadas, com fontes de água vegetocão local ad equ do e confotável para sentar para que possam caminar com fontes de água, vegetaçăa, local adequado e confortavel para sentar, para que possam caminhar acompanhados de enfermetros e acessivel para caderas de rodas e macas. No caso de pacientes que não possam ir para fora, as janelas devem permitir o contato com o exterior, para que eles possam identificar as diferentes épocas do ano, horas do dia e o tempo, se chuvoso, nublado ou ensolarado. ${ }^{13}$

Está claro que uma concepção diferenciada e o desenvolvimento técnico dos equipamentos fizeram com que os profissionais da área de arquitetura, medicina e administração percebessem de maneira diferente toda a problemática envolvida no planejamento desses espaços. Também está clara a preocupação em melhorá-los cada vez mais. O que se torna necessário, então, é um "outro olhar" sobre técnicas atuais para se conseguir novos e mais efetivos resultados para os projetos arquitetônicos de saúde. Até mesmo porque "a previsão e detecção precoce de falhas ou defeitos coíbem interrupções e interdições evitáveis e mobilização e dispêndios desnecessários." ${ }^{\text {"I Inclusive }}$ "...hospitais são muito caros para serem utilizados com ineficiência."15

\subsection{Legislação}

Art. 196, da Constituição Federal: A saúde é direito de todos e dever do Estado, garantido mediante políticas sociais e econômicas que visem à redução do risco de doença e de outros agravos e ao acesso universa igualitário às acõoes e sevviços para sua promoção, proteç̃ao e recuperação.

TOLEDO, em seu livro "Feitos Para Curar", transcreve uma entrevista feita com Regina Barcellos e Flávio Bicalho, profissionais com efetiva participação na elaboração das normas nacionais voltadas para os Estabelecimentos Assistenciais de Saúde.

Embora haja iniciativa anterior (1965) que demonstra que já havia preocupação com a legislação no Brasil, pelo que se pode concluir em função da entrevista, o início na normatização para os EAS no Brasil começou na década de 70 com a denominada Portaria no. 400 que tinha como título "Normas para instalações de Hospitais Gerais até 150 Leitos".

Tal portaria na verdade tinha uma abordagem parecida com as normas da ABNT. Nela havia a listagem de ambientes por unidade, com dimensionamento e observações básicas de necessidade, proximidade e circulação de pessoas e insumos.

Com a Constituição de 1988, a área da saúde teve uma mudança geral, onde se estabeleceu com clareza o dever do Estado de atender toda a população na questão da saúde. Estes avanços 
decorreram do movimento chamado Reforma Sanitária que culminou em 90 com a Lei Orgânica da Saúde, que definiu o SUS (Sistema Único de Saúde), com suas competências nos níveis federal, estadual e municipal - conceito de vanguarda e de difíili implantação. 0 sistema incorpora uma série de idéias, dentre as quais podemos destacar a participação da comunidade, o planejamento ascendente, o enfoque na prevenção, a descentralização do serviço.

A criação da portaria no. 1.884, em 1994, veio com o objetivo de proporcionar maior liberdade e flexibilidade ao projetista quando da elaboração dos EAS. É uma norma que, de certa maneira, pode ser entendida como um quebra-cabeça onde há inúmeras peças que permitem então montar várias propostas e desenhos, cada uma particular e normatizada.

Os entrevistados também colocam no desenvolvimento da entrevista, várias tendências que visualizam no setor:

- 0 edifício tem influência na forma de agir das equipes médica e de enfermagem e também no paciente, permitindo a ele recuperar sua saúde em um ambiente agradável. Desta forma demonstra que o edifício, como um produto arquitetônico, pode vir a ter um papel importante no processo de cura.

- Crescimento dos serviços de saúde especializados. Percebe-se uma fragmentação nos serviços. Ta colocação pode ser observada nos hospitais da Rede SARAH, no Hospital do Câncer de Barretos e mesmo na Santa Casa de Porto Alegre, onde todo o complexo é dividido em vários prédios e cada um tem um papel e funcionamento independente. Mais que isso: tal experiência mostra que esta situaç̃o contribui em muito para elevar o padrão de atendimento ao paciente, geralmente público (SUS) e consequentemente uma melhora no seu processo de cura.

- Terceirização de serviços de apoio, tais como lavanderia, esterilização. Com a normatização eficiente em vigência, tais ambientes podem perfeitamente ser instalados em locais independentes ao EAS de maneira a permitir melhor utilização do espaço disponível, grande dificuldade atual, principalmente nos hospitais dos grandes centros.

Lei orgânica de saúde

A lei no. 8080 de setembro de 1990, conhecida como Lei Orgânica da Saúde, é a lei que define o Sistema Único de Saúde - SUS e suas atribuições.

Ela coloca as disposições gerais, os objetivos e atribuições, os princípios e diretrizes, a organização direção e gestão, competências, e atribuições do SUS especificamente; coloca o funcionamento e a participação complementar dos serviços privados de assistência à saúde; coloca a organização dos recursos humanos; e recursos, gestão financeira, planejamento e orçamento de financiamentos.

No artigo $4^{\circ}$, fica clara a descentralização do conjunto de ações e serviços de saúde prestados por órgãos e instituições públicas e coloca que a iniciativa privada poderá participar do Sistema Único de Saúde em caráter complementar.

Estão incluídas no campo de atuação do Sistema Único de Saúde - SUS, a execução das açães de vigilância sanitária, vigilância epidemiológica, de saúde do trabalhador e assistência terapêutica integral, inclusive farmacêutica; a participação na formulação da política e na execução de ações de saneamento básico; a ordenação da formação de recursos humanos na área de saúde; a vigilância nutricional e a orientação alimentar; a formulação da política de interesse para a saúde e a participação na sua produção; o controle e a fiscalização de serviços, produtos e substâncias de interesse para a saúde; a fiscalização e inspeção de insumos para consumo humano dentre outros.

Com relação aos princípios e diretrizes, de acordo com a Constituição Federal, as ações e serviços públicos de saúde e serviços privados contratados obedecem aos princípios de universalidade de acesso aos serviços de saúde; integralidade de assistência; preservação da autonomia das pessoas: igualdade da assistência à saúde, direito à informação, participação da comunidade, descentralização político-administrativa. Dá ênfase na descentralização dos serviços para os municípios, regionalização e hierarquização da rede de serviços de saúde, conjugação dos recursos financeiros, tecnológicos, materiais e humanos da União à saúde da população e capacidade de resolução dos serviços em todos os níveis de assistência, entre outros.

Relativamente à organização, direção e gestão, a lei coloca que a direção do Sistema Único de Saúde - SUS, será exercida em cada esfera de governo pelos órgãos do Ministério da Saúde no âmbito da União, pelas Secretarias de Saúde ou órgão equivalente no âmbito dos Estados e Distrito Federal e pelas respectivas Secretarias de Saúde ou órgãos equivalentes no âmbito dos Municípios.

A lei ainda coloca as atribuições comuns entre a União, os Estados, o Distrito Federal e os Municípios, a competência exclusiva da direção nacional do Sistema Único de Saúde - SUS, a direção estadual do Sistema Único de Saúde e a direção municipal do Sistema Único de Saúde.

Entre as várias competências da direção nacional do SUS estão: participar na formulação e implementação das políticas como saneamento básico ou condições relativas aos ambientes de trabalho; definir e coordenar os sistemas de redes integradas de assistência de alta complexidade de rede de laboratórios de saúde pública, de vigilância epidemiológica e sanitária; participar da definição de normas e mecanismos de controle; coordenar e participar na execução das ações de 
vigiância epidemiológica; promover articulação com os órgãos educacionais e de fiscalização do exercício profissional; prestar cooperação técnica e financeira aos Estados, ao Distrito Federal e aos Municípios; elaborar normas para regular as relações entre o SUS e os serviços privados; promover a descentralização dos serviços e ações de saúde; elaborar planejamento estratégico nacional em cooperação técnica com os Estados, Municípios e Distrito Federal; e estabelecer o Sistema Nacional de Auditoria.

Entre as várias competências da direção estadual do SUS estão: promover a descentralização para os Municííios dos serviços e das ações de saúde; acompanhar e avaliar as redes hierarquizadas do SUS: prestar apoio técnico e financeiro aos Municípios; coordenar e, em caráter complementar, executar ações e serviços de vigilância epidemiológica e sanitária, de alimentação e nutrição e de saúde do trabalhador; identificar estabelecimentos hospitalares de referência e gerir sistemas públicos de alta complexidade, de referência estadual e regional; e estabelecer normas em caráter suplementar.

Entre as várias competências da direção municipal do SUS estão: participar em articulação com a sua direção estadual do planejamento, programação e organização da rede regionalizada e hierarquizada do SUS; executar serviços de vigilância epidemiológica e sanitária, de alimentação e nutrição, de saneamento básico e de saúde do trabalhador; formar consórcios administrativos intermunicipais: gerir laboratórios públicos de saúde e hemocentros; celebrar contratos e convênios com entidades prestadoras de serviços privados de saúde, bem como controlar e avaliar sua execução; controlar e fiscalizar os procedimentos dos serviços privados de saúde; e normatizar complementarmente as aç̃es e serviços públicos de saúde no seu âmbito de atuaç̃o.

Com relação aos serviços privados de assistência à saúde, a lei coloca diretrizes de funcionamento e da participação complementar.

Relativamente às diretrizes do funcionamento, o artigo 20 dispõe que tais serviços, os privados, caracterizam-se pela atuação por iniciativa própria na promoção, proteção e recuperação da saúde: o artigo 21 que a assistência à saúde é livre à iniciativa privada; o artigo 22, que na prestação de serviços, serão observados os princípios éticos e as normas expedidas pelo órgão de direção do SUS quanto às condiç̃̃es para seu funcionamento; $\mathrm{e}$ o artigo 23 dispõe que é vedada a participação direta ou indireta de empresas ou de capitais estrangeiros na assistência à saúde com algumas ressalvas.

Relativamente à participação complementar, o artigo 24 estabelece que quando as suas disponibilidades forem insuficientes para assistir à população de uma determinada área, o SUS poderá recorrer aos serviços ofertados pela iniciativa privada; segundo o artigo 25, as entidades filantrópicas e as sem fins lucrativos terão preferência para participar do SUS; e o artigo 26 coloca que os critérios e valores para remuneração de serviços serão estabelecidos pela direção nacional do SUS.
O artigo 27 diz claramente que a política de recursos humanos na área da saúde será formalizada e executada pelas diferentes esferas de governo.

A lei ainda traz, através de seus artigos 31 a 38, a normatização para obtenção, gestão e planejamento de recursos.

Portaria no 1884 - do Ministério da Saúde

A portaria no. 1884, de 11 de novembro de 1994, dispõe que, através do Ministério de Estado da Saúde, em função da necessidade, sobre as formas de atualizar as normas existentes até então na área de infra-estrutura física em saúde; em funcão da necessidade de dotar as Secretarias Estaduais e Municipais de instrumento norteador que atenda aos princípios de regionalização, hierarquização acessibilidade e qualidade da assistência prestada à população; a necessidade das Secretarias Estaduais e Municipais contarem com um instrumento de avaliação de projetos físicos, adequado às novas tecnologias na área da saúde, resolve aprovar normas destinadas ao exame e aprovação de Projetos Físicos de Estabelecimentos Assistenciais de Saúde pública ou privada para as construções novas, as áreas a serem ampliadas e as reformas

De maneira mais técnica e até mesmo didática, esta portaria estabelece de maneira bastante eficiente os critérios para: a elaboraç̃ão dos projetos físicos; a programação físico-funcional dos Estabelecimentos Assistenciais de Saúde; a quantificação, dimensões especiais e instalações prediais dos ambientes; as circulações internas e externas; as condições ambientais de conforto; os ambientes funcionais dos Estabelecimentos Assistenciais de Saúde que demandam obscuridade; as condicões ambientais de controle de infeccão hospitalar; e as condicões de segurança contra incêndio. Além disso, coloca no adendo uma lista de eficientes tabelas que em função da população básica dos Estabelecimentos Assistenciais de Saúde (paciente, doador, funcionário, aluno, público e seus respectivos sub-grupos) estabelece as unidades/ambientes necessários bem como seu dimensionamento (quantificação e dimensão) e suas respectivas instalações básicas.

Para a elaboração de projetos físicos, a portaria coloca que todos os projetos de estabelecimento assistencial de saúde - EAS terão que ser elaborados em conformidade com as suas disposições relativas à̀ terminologia (estudo preliminar, projeto básico e projeto executivo); etapas de projeto; responsabilidades apresentação de desenhos e documentos; tipos e siglas adotadas; e aprovação de projeto.

Para programação físico-funcional dos estabelecimentos assistenciais de saúde, a metodologia utilizada é a apresentação da listagem do conjunto das atribuições e atividades do EAS, nela tratado genericamente, sem compromisso com soluções padronizadas visando apresentar aos projetistas e avaliadores um leque das diversas atividades e os ambientes respectivos em que elas ocorrem. 
Esta listagem contém as atribuiç̃es e atividades com a qual se pode montar o estabelecimento desejado de maneira a definir estabelecimentos específicos, ficando desta maneira, a decisão do tipo de estabelecimento a ser implantado a cargo dos gestores e técnicos e não mais de acordo com padrões pré-estabelecidos nacionalmente.

Para a quantificação, dimensões especiais e instalações prediais dos ambientes, a resolução aborda os aspectos espaciais estritamente relacionados com as diversas atribuiç̃ôes e atividades dos Estabelecimentos Assistenciais de Saúde. Entende que o ambiente é entendido como espaço fisicamente determinado e especializado para o desenvolvimento de determinada atividade, caracterizado por dimensões e instalações diferenciadas. São enfocados os aspectos relativos ao dimensionamento e às instalações necessárias a cada ambiente. 0 dimensionamento é expresso pela dimensão espacial (superfície e dimensão mínima) e a quantificação refere-se ao número de vezes que o mesmo ambiente se repete.

Aos critérios para projetos de estabelecimentos assistenciais de saúde, são apresentadas variáveis que orientam e regulam as decisões a serem tomadas nas diversas etapas de desenvolvimento de projeto. São elas: circulações externas e internas; condições ambientais de conforto; condições ambientais de controle de infecção hospitalar; instalações prediais ordinárias e especiais; e condições de segurança conta incêndio.

A portaria ainda coloca que, para determinação das relações entre as diversas atribuições do Estabelecimento Assistencial de Saúde faz-se necessário reconhecer as categorias de pessoas usuárias e circulantes no estabelecimento, que, via de regra, definirão os fluxos e acessos. As categorias para esta população são: paciente (interno e externo), doador (de sangue ou leite humano), funcionário (administrativo ou assistencial), aluno (técnico, graduação, pós-graduação e estágio) e público (acompanhante de paciente, visitante de paciente, fornecedor de materiais, prestador de serviços, vendedor de materiais e serviços e visitante)

A partir daí, são colocadas as tabelas das unidades funcionais, tabelas estas que discriminam a atividade, unidades/ambientes, dimensionamento (quantificação e dimensão) e as instalações. As unidades funcionais constantes desta resolução são: ações básicas de saúde; ambulatório atendimento imediato (atendimentos de emergência e urgência); internação (geral, recém-nascido, intensiva e para tratamento de queimados); apoio ao diagnóstico e terapia (patologia clínica, imagenologia, métodos gráficos, anatomia patológica, medicina nuclear, centro cirúrgico, centro obstétrico, reabilitação, hemoterapia/hematologia, radioterapia, quimioterapia, diálise e banco de leite); apoio técnico (nutrição e dietética, farmácia e central de material esterilizado); ensino e pesquisa; apoio administrativo; e apoio logístico (processamento de roupa, central de administração de materiais e equipamentos, manutenção, conforto e higiene, limpeza e zeladoria).
A seguir, de forma ilustrativa, segue uma das tabelas citadas: Desta forma, conforme colocaram

\begin{tabular}{|c|c|c|c|c|}
\hline NOATN. & UNIDADE / AMBIENTE D & DIMENSIONAMENTO & & INSTALAÇŌES \\
\hline & & $\begin{array}{l}\text { QuANTIFICAÇ̄ōo } \\
\text { (man) }\end{array}$ & DIMENSÁO(min) & \\
\hline \multirow[t]{2}{*}{ 3.1:3.2. } & $\begin{array}{l}\text { Atendimentos de } \\
\text { Emergencia e Urgencia } \\
\text { (coont) }\end{array}$ & & & \\
\hline & $\begin{array}{l}\text { Emergéncias (alta } \\
\text { complexidade) e Urgências }\end{array}$ & & & \\
\hline 32 & $\begin{array}{l}\text { Ares extema para } 1 \\
\text { ceserenbarve } \\
\text { ambulándas }\end{array}$ & & $\begin{array}{l}21,00 \mathrm{~m}^{2} \text { de area } \\
\text { cobeta }\end{array}$ & \\
\hline 32 & $\begin{array}{l}\text { Area de recepsăo de } 1 \\
\text { pacientes }\end{array}$ & & $\begin{array}{l}\text { sificiente pora } \\
\text { recebinento of } 1 \\
\text { maca }\end{array}$ & \\
\hline 3.24 & Sola de serniço social & 1 & $8,0 \mathrm{~m}^{2}$ & \\
\hline 3.2 .2 & Sola de Higienizaç̧o & & $8,0 \mathrm{~m}^{2}$ & $\mathrm{HF} ; \mathrm{HQ}$ \\
\hline 3.24 & $\begin{array}{l}\text { Pusto de ertermagem /1 } \\
\text { prescriçăo médca }\end{array}$ & $\begin{array}{l}11 \text { para cada } 12 \text { letor } \\
\text { de observaçáa. }\end{array}$ & $0,6,0 \mathrm{~m}^{2}$ & HF \\
\hline 3.2 .4 & Sala de serviços & $\begin{array}{l}\text { Cada posto deve se } \\
\text { serniso por so mence } \\
1 \text { sala. }\end{array}$ & 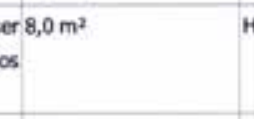 & HF \\
\hline $3.1 .4 \mathrm{a} 3.1 .7$ & Sola de isolamerto & 1 & $8,0 \mathrm{~m}^{2}$ & $H F ; H Q ; F O F A M ; E E$ \\
\hline \multicolumn{5}{|l|}{3.2 .4 a 3.2 .7} \\
\hline $\begin{array}{l}3.1 .4 \dot{a} 3.1 .7 \mathrm{e} \\
3.2 .4 \mathrm{a} 3.27\end{array}$ & $\begin{array}{l}\text { Sola coletive de } \\
\text { observaço } \\
\text { pediatia/adolescente de }\end{array}$ & $\begin{array}{l}\text { el de pediatria, } 2 \text { de } \\
\text { codulto-(mas e ferm). } \\
n^{\circ} \text { de lettos } \\
\text { calcuado sobre } \\
\text { estimativa }\end{array}$ & $\begin{array}{l}\text { de } 8,5 \mathrm{~m}^{2} \text { por leito } \\
0 \\
\dot{e} \\
0\end{array}$ & HF;FOFAM,EE \\
\hline $\begin{array}{l}3.1 .4 \dot{\mathrm{a}} 3.1 .7 \mathrm{e} \\
3.2 .4 \mathrm{a} 3.2 .7\end{array}$ & 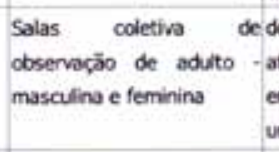 & $\begin{array}{l}\text { edo total } \\
\text { - atendmentos do } \\
\text { emergencias } \\
\text { urgencia }\end{array}$ & $\begin{array}{l}\text { de } 8,5 m^{2} \text { por ierio } \\
\text { de } \\
\text { e }\end{array}$ & HF:FO:FAM;EE \\
\hline \multirow[t]{2}{*}{$\begin{array}{l}\text { 3.1.5 } 3.1 .7 \mathrm{e} \\
\text { 3.2.1;3.2.3 } \\
3.2 .7\end{array}$} & $\begin{array}{l}\text { Sola de procedmentes } \\
\text { espociais (imvasnos) }\end{array}$ & & $20,0 \mathrm{~m}^{2}$ & $\begin{array}{l}\text { FO:FN:FUC; } \\
F A M ; A C ; E F ; E D\end{array}$ \\
\hline & Área de escovaço & $\begin{array}{l}2 \text { tomeiras por sal: } \\
\text { invasinos }\end{array}$ & sta $1,10 \mathrm{~m}^{2}$ por tomeira & HF;HQ \\
\hline 3.25 & $\begin{array}{l}\text { Sala de gesso e redurāo } 1 \\
\text { de fraturas }\end{array}$ & & 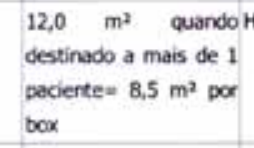 & \\
\hline $3.2 .1 ; 3.2 .3$ & 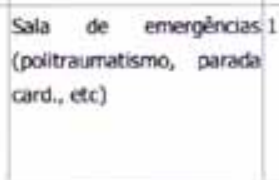 & & $\begin{array}{l}12 m^{2} n / \text { leito (2 leitos } \\
\text { no min). com } \\
\text { distáncia de im.entre } \\
\text { estes e paredes, } \\
\text { exceto cabeceira }\end{array}$ & $\begin{array}{l}\text { HF;FO:FN:FVC; } \\
\text { FAM,AC:EE }\end{array}$ \\
\hline
\end{tabular}


Regina Barcellos e Flávio Bicalho: "é uma norma que de certa maneira pode ser entendida como um quebra-cabeça onde há inúmeras peças que permitem então montar várias propostas e desenhos, cada uma particular e normatizada".

Resolução - RDC n 50 - da ANVISA

A constante evolução das técnicas e tecnologias da área da saúde faz com que as normas vigentes rapidamente fiquem defasadas. Em função disso elas precisam ser atualizadas com a maior frequência possível, conforme comenta TOLEDO:

O maior problema da normatização, segundo Lelé, é que as normas não têm acompanhado, com a velocidade necessária, as transformacões que ocorrem, a cada dia, nos tratamentos e demais procedimentos hospitalares, e muito menos a evolução dos equipamentos. Desta forma, torna-se extremamente dificil para os arquitetos que não convivem com a rotina de uma unidade hospitalar. manter-se em dia com estas transformações, uma vez que o acesso a informações, para a maioria dos projetistas, se limita àquelas que já foram codificadas."

A norma que está em vigor atualmente desde 2002, é a RDC no. 50 e é a norma que regulamenta o planejamento físico de todos estabelecimentos assistenciais de saúde - EAS. TOLEDO muito didaticamente explica a norma:

De acordo com a RDC no.50 (ANVISA, 2004, P.38), a composição funcional de um EAS varia em função de suas atribuições específicas, tais como:

1 Prestação de atendimento eletivo de assistência à saúde em regime ambulatorial e de hospital dia - atenção à saúde incluindo atividades de promoção, prevenção vigilância à saúde da comunidade e atendimento a pacientes externos, de forma programada e continuada;

2 Prestação de atendimento imediato de assistência à saúde - atendimento a pacientes externos em situaç̧ões de sofrimento, sem risco de vida (urgência) ou com risco de vida (emergência),

3 Prestação de atendimento de assistência à saúde em regime de internação- atendimento a pacientes que necessitam de assistência direta programada por período superior a 24 horas (pacientes internos):

4 Prestação de atendimento de apoio ao diagnóstico e terapia - atendimento a pacientes internos e externos em ações de apoio direto ao reconhecimento e recuperação de estado de saúde (contato direto);

5 Prestação de serviços de apoio técnico - atendimento direto e assistência à saúde em funções de apoio (contato indireto);

6 Formação e desenvolvimento de recursos humanos e de pesquisa - atendimento direto ou indiretamente relacionado à atenção e assistência à saúde em funções de ensino e pesquisa;
7 Prestaçãodeserviços deapoioàgestãoeexecuçãoadministrativa-atendimentoaoestabelecimento em funções administrativas:

8 Prestação de serviços de apoio logístico - atendimento ao estabelecimento em funções de suporte operacional.

As quatro primeiras atribuiç̃oes relacionadas são atribuições-fim, isto é, elas constituem funções diretamente ligadas à atenção e à assistência à saúde. As quatro últimas são atribuições-meio para o desenvolvimento das primeiras e de si mesmas. A cada atribuicão, por sua vez corresponde um grande número de atividades e subatividades que se desenvolvem nos ambientes hospitalares ${ }^{18}$

De fato, a RDC no. 50 veio, em 2002, substituir a Portaria no. 1884 de 11 de novembro de 1994 Na verdade não foi exatamente uma substituição, mas uma atualização, aprofundamento e complementação da portaria anterior (no. 1884). Comparando-se as duas, vê-se que são praticamente a mesma, porém a segunda apresenta um grau de detalhamento e abrangência maior.

Entre inúmeros complementos, pode-se colocar, por exemplo, que, no item elaboração de projetos físicos, a RDC no. 50 faz, além das exigências constantes na Portaria no. 1884, a exigência de um parecer técnico (visando a adequação do projeto arquitetônico às atividades propostas pelo EAS, como funcionalidade do edifício, dimensionamento dos ambientes, instalações ordinárias e especiais e especificacão básica dos materiais). procedimentos (item voltado para elucidar situacõoes que esgotam todas as possibilidades de cumprimento integral da norma) e condições para obras financiadas por Órgãos Públicos.

Além de mais completa, sua conformação atual, embora tenha o mesmo conteúdo, é mais didática e favorável, muito mais voltada para o público técnico das áreas da arquitetura e das engenharias do que a Portaria no. 1884. Ainda há muito a ser atualizado nas portarias, mas ela continua atendendo ao seu objetivo, que é permitir a montagem de inúmeras propostas de desenhos de forma particular e normatizada.

De qualquer forma, a adequação total dos estabelecimentos às normas ainda continua sendo uma tarefa difíili, e mais, conforme comenta TOLEDO, o fato de projetos buscarem ou mesmo oferecerem qualidade a estes estabelecimentos já os colocariam mais próximos da legislação.

As exigências feitas pela Resolução quanto ao conteúdo das etapas projetuais nada mais são do que aquelas necessárias à elaboração de um projeto arquitetônico de boa qualidade. Devemos reconhecer, no entanto, que apenas raramente tais exigências são cumpridas na integra, ainda que se trate de uma edificação complexa como o hospital, em que a falta de um bom projeto redunda, inúmeras vezes, em falhas de dificil correção, que podem produzir agravos importantes à saúde dos pacientes e dos próprios funcionários da unidade. ${ }^{1}$ 


\subsection{SUS - Sistema Único de Saúde}

o SUS - Sistema Único de Saúde - é o sistema de saúde pública vigente atualmente no Brasil e foi criado com a Constituição de 1988, que diz, no:

Art. 196: A saúde é direito de todos e dever do Estado, garantido mediante políticas sociais e econômicas que visem à redução do risco de doença e de outros agravos e ao acesso universal e igualitário às aç̃oes e serviços para sua promoção, proteção e recuperação.

Art. 197: São de relevância pública as ações e serviços de saúde, cabendo ao poder público dispor, nos termos da lei, sobre sua regulamentação, fiscalizaç̃ã e controle, devendo sua execução ser feita diretamente ou através de terceiros e, também, por pessoa física ou juŕdica de direito privado.

Art. 198: (*) As ações e serviços públicos de saúde integram uma rede regionalizada e hierarquizada e constituem um sistema único, organizado de acordo com as seguintes diretrizes:

I- descentralização, com direção única em cada esfera de governo;

\| - atendimento integral, com prioridade para as atividades preventivas, sem prejúź dos senvicos assistenciais III - participação da comunidade.

Parágrafo único. 0 Sistema único de Saúde será financiado, nos termos do art. 195, com recursos de orçamento da seguridade social, da União, dos Estados do Distrito Federal e dos Municípios, além de outras fontes

(*) Emenda Constitucional no. 29, de 2000.

Art. 199: A assistência à saúde é livre à iniciativa privad.

$\$ 1^{0}$. As instituiç̧ões privadas poderão participar de forma complementar do Sistema Único de Saúde, segundo diretrizes deste, mediante contrato de direito público ou convênio tendo preferência as entidades filantrópicas e as sem fins lucrativos.

$\mathbf{S} \mathbf{2}^{\mathbf{2}}$.E vedada a destinação de recursos públicos para auxilios ou subvençōes às instituições privadas com fins lucrativos.

\$3. É vedada a participaçăo direta ou indireta de empresas ou capitais estrangeiros na assistência à saúde no Pais, salvo nos casos previstos em lei.

§4. A lei disporá sobre as condições e os requisitos que facilitem a remoção de órgãos, tecidos e substâncias humanas para fins de transplante, pesquisa e tratamento, bem como a coleta, processamento e transfusão de sangue e seus derivados, sendo vedado todo tipo de comercialização.

Art. 200: Ao Sistema Único de Saúde compete, além de outras atribuições, nos termos da lei:

I - controlar e fiscalizar procedimentos, produtos e substâncias de interesse para a saúde e participar da produção de medicamentos, equipamentos, imunobiológicos, hemoderivados e outros insumos:

\|l - executar as açōes de vigilância sanitária e epidemiológica, bem como as de saúde do trabalhador:
III - ordenar a formação de recursos humanos na área de saúde;

IV - participar da formulação da política e da execução das aç̃oes de saneamento básico:

V - incrementar em sua área de atuação o desenvolvimento científico e tecnológico;

$\mathrm{VI}$ - fiscalizar e inspecionar alimentos, compreendido o controle de seu teor nutricional, bem como bebidas e águas para consumo humano,

VII - participar do controle e fiscalização da produção, transporte, guarda e utilização de substâncias e produtos psicoativos, tóxicos e radioativos.

VIII - colaborar na proteç̃o do meio ambiente, nele compreendido o do trabalho. ${ }^{20}$

Com a Lei Orgânica de Saúde, Lei no. 8080 de 1990, o SUS tem sua regulamentação. Ela regula em todo o território nacional, as aç̃oes do SUS, estabelecendo as diretrizes para seu gerenciamento e descentralização e detalhando as competências de cada esfera governamental. Dentre uma série de definições, garante a gratuidade das ações e dos serviços nos atendimentos públicos e privados contratados e conveniados ao SUS.

O SUS vem sendo implementado como processo social em permanente construção. Embora sua constituição formal tenha acontecido na Constituição de 1988, suas origens são registradas a partir da crise do modelo médico assistencial privativista hegemônico da segunda metade do século passado. Tal modelo se caracterizava por: extensão de cobertura previdenciária, privilegiar a prática médica curativa e individual em detrimento das ações coletivas; criação de um complexo médico-industrial e pelo deslocamento da prestação dos serviços médicos a entes privados lucrativos e não-lucrativos.

Com as mudanças políticas e econômicas ocorridas nas décadas de 1970 e 1980, este modelo teve seu esgotamento. 0 processo de redemocratização do Brasil estabelece novos rumos às políticas públicas e faz surgir novos atores sociais, que propõem um novo modelo de atenção à saúde: os primeiros projetos de medicina comunitária concebidos pelas secretarias estaduais de saúde e instituições acadêmicas, além de, paralelamente, iniciarem-se as primeiras experiências de municipalização da saúde.

Em 1971, é criado o Funrural (Fundo de Assistência e Previdência do Trabalhador Rural) que incorpora a população rural ao sistema de prestação de serviços. Em 1972, tem início, na cidade de Montes Claros, norte de Minas Gerais, um projeto experimental com o objetivo de buscar modelos de extensão de cobertura. Do sucesso deste projeto piloto, surge o Piass (Programa de Interiorização das Ações de Saúde e Saneamento) que provavelmente foi a primeira grande experiência brasileira de extensão de cobertura a baixo custo e com integração interinstitucional.

20 BRASIL (2003, p. 20 e 21) 
Em 1978, foi formulada a Declaração de Alma-Ata, através da Conferência Internacional sobre Cuidados Primários de Saúde, em Alma-Ata no atual Cazaquistão. Tal declaração expressa a necessidade de ação urgente de todos os governos e da comunidade mundial para promover a saúde de todos os povos do mundo.

Em 1986, acontece no Brasil o evento político-sanitário mais importante da segunda metade do século passado: a VIII Conferência Nacional de Saúde, na qual foram lançadas as bases de um novo Sistema de Saúde, bases estas que serviram de referência à elaboração da Seção da Saúde da Constituição Federal de 1988

Em 1987, é implantado o Sistema Unificado e Descentralizado de Saúde (Suds) que busca incorporar alguns elementos da proposta da reforma sanitária: a universalização; a descentralização aos estados; e a democratização das instâncias gestoras.

Em 1988, cria-se o Conselho Nacional de Secretarias Municipais de Saúde (Conasems) que unto com o Ministério da Saúde e o CONASS (Conselho Nacional de Secretários de Saúde) compõem a Comissão Intergestores Tripartite (CIT), colegiado responsável pela gestão do SUS.

\section{Como princípios básicos, o SUS tem:}

Descentralização das aç̃oes de saúde e o seu caráter participativo. Tendo o Brasil dimensões continentais, é natural que existam especificidades regionais. Desta forma, a parceria com os Estados e Municípios torna-se fundamental.

Universalidade: o SUS deve atender a todos, sem distinções ou restrições, sem qualquer custo.

Integralidade: o SUS deve oferecer a atenção necessária à saúde da população, promovendo ações contínuas de prevenção e tratamento aos indivíduos e às comunidades, em quaisquer níveis de complexidade.

Equidade: o SUS deve disponibilizar recursos e serviços com justiça, de acordo com as necessidades de cada um, canalizando maior atenção aos que mais necessitam.

Participação social: é direito e dever da sociedade participar das gestões públicas em geral, particularmente da saúde pública, e dever do poder público garantir as condições para essa participação.

De maneira bastante objetiva, o Ministério da Saúde resume os vinte primeiros anos de existência do SUS: em 1988, o SUS foi criado: em 1990, foi regulamentado; em 1993, foi extinto o INAMPS (Instituto Nacional de Assistência Médica da Previdência Social) e regulamentado o processo de descentralização da gestão dos serviços e ações do SUS; em 1994, é criado o Programa Saúde da Família; em 1996, é implantada a distribuição gratuita de medicamentos aos portadores de HIV em 1997, é criado o Sistema Nacional de Transplantes; em 1998, é instituído o Piso de Atenção Básica para viabilizar a organização da atenção básica à saúde nos municípios brasileiros; em 1999, é criada a ANVISA - Agência Nacional de Vigialância Sanitária; é estabelecido, no país, o medicamento genérico, e tem início a Campanha Nacional de Vacinação contra gripe, tétano e difteria, para a Terceira Idade; em 2000, é criada a ANS - Agência Nacional de Saúde Suplementar em 2001 o Brasil alcança a marca de 150 mil Agentes Comunitários de Saúde, antecipando a meta prevista para o fim de 2002; é aprovada a Norma Operacional de Assistência à Saúde NOAS - que define a regionalização e a descentralização da assistência à saúde; em 2003, é criado o Serviço de Atendimento Móvel de Urgência (SAMU); em 2004, é instituída a Política Nacional de Humanização do Sistema Único de Saúde (HumanizaSUS), é lançado o programa "Brasil Sorridente", que visa melhorar as condições de saúde bucal da população brasileira, é lançado, também, o programa "Farmácia Popular do Brasil" e é publicada a Política Nacional de Atenção Integral à Saúde da Mulher; em 2006, é incorporada a vacinação contra rotavírus no Calendário Básico de Vacinação da Criança e lançada a Política da Pessoa Idosa; em 2007, é lançado o Programa Mais Saúde - PAC e é lançado o Programa Nacional de Telesaúde e, em 2008, são implantadas as aç̃̃es do "Programa Mais Saúde - PAC: Saúde direito de todos".

Após mais de vinte anos de criação do SUS, o Ministério da Saúde divulga avaliação do Sistema através da opinião da população. Entre os itens aprovados pela população estão: acolhimento, acessibilidade e atendimento com qualidade aos usuários; gestão competente e transparente no setor Saúde; Valorização e educação continuada dos profissionais; participação e controle social com os conselhos de saúde; financiamento estável com recursos federais, estaduais e municipais; respeito às diferenças étnicas e culturais; pesquisa, tecnologia e inovação nos serviços e ações de saúde; regulação com eficiência do setor privado; vigilância permanente em saúde, ambiental e sanitária; e mais saúde para a população com políticas públicas integradas.

Entre os itens desaprovados pela população estão: falta de recursos financeiros para a saúde má gestão de recursos públicos e corrupção; demora na fila do atendimento; falta de respeito aos direitos dos usuários; pouca fiscalização por parte dos órgãos competentes e da sociedade; obras inacabadas e equipamentos que não trazem melhorias; prejuízo para os cofres públicos e superfaturamento; metas dos programas não cumpridas; falta de política de recursos humanos e de concurso público; e serviços em condições precárias e sem profissionais. 
De fato, o SUS trouxe ao Brasil maior qualidade na área da saúde pública. Muito se evoluiu o que é reconhecido inclusive internacionalmente. Nesta questão, porém há muito, ainda, a evoluir. o SUS é um sistema de sucesso, foi implantado com sucesso, mas está, e sempre estará, em busca aprimoramento.

Ao SUS cabe a tarefa de promover, proteger e recuperar a saúde, garantindo atenç̃oo qualidade contínua aos indivíluos às coltividades de forma equitativa ${ }^{21}$

\subsection{HumanizaSUS - política nacional de humanização do SUS}

Em 2002, com o SUS já em funcionamento há mais de 10 anos, uma avaliação de seu funcionamento foi feita pelo Ministério da Saúde, no texto A Política de Saúde no Brasil nos anos 90: Avanços e Limites.

Nele, o problema da desigualdade regional na oferta de serviços foi colocado como um problema crônico. No campo do custeio, o processo de descentralização e do regionalismo fez muito para que se estabelecessem mecanismos mais justos de alocação de recursos. Alguns programas do Ministério da Saúde, naquela época, lidaram com o desafio de aumentar a capacidade instalada do sistema, como o Programa de Apoio à Implantação de Sistemas Estaduais de Referência Hospitalar para o Atendimento de Urgência e Emergência, o Programa de Gestante de Alto Risco, o Programa de Reequipamento Hospitalar e o Projeto Expande Centro de Alta Complexidade em Oncologia. Ao passo em que a política de custeio caminhava coerentemente com os investimentos, os mecanismos de financiamento e de aplicação de recursos mostravam-se preocupantes naquele momento.

A desigualdade na distribuição e na qualificação dos recursos humanos consistia em grande obstáculo. Para sua superação, o Programa de Interiorização do Trabalho em Saúde visava alocar profissionais de medicina e enfermagem nos municípios, o Programa Saúde da Família tornou-se um instrumento para facilitar a permanência de profissionais nos municípios de menor porte e o Projeto de Profissionalização dos Trabalhadores da Área de Enfermagem buscavam a melhoria da qualificação, conforme sintetiza a colocação abaixo:

A manutenç̃̃o de gastos permanentes com treinamento e atualização dos profissionais de saúde, voltados para o atendimento mais dedicado será um desafio constante para os próximos administradores. ${ }^{22}$
O avanço da descentralização abriu perspectivas de grande desenvolvimento no gerenciamento do SUS, pela inserção de atores e pela maior possibilidade de participação social. Desta forma concluiu-se que, na década que se iniciava (2000), a saúde estava em melhores condições de executar suas políticas e gerar bons resultados.

O HumanizaSUS - Política Nacional de Humanização da atenção e gestão do SUS (2003) surge atrelado ao compromisso de uma efetivação real do Sistema Único de Saúde, partindo do reconhecimento do "SUS que dá certo".

Por humanização, o Ministério da Saúde compreende a valorização dos diferentes sujeitos envolvidos no processo de produção de saúde - usuários, trabalhadores e gestores. Como valores principais desta política estão a autonomia e o protagonismo dos sujeitos, a coresponsabilidade entre eles, os vínculos solidários e a participação coletiva no processo de gestão. Um SUS humanizado significa um SUS em todas suas instâncias, programas e projetos comprometidos com a humanização.

Como princípios norteadores, a Oficina Nacional de HumanizaSUS 'Construindo A Política Nacional de Humanização', realizada em 19 e 20 de novembro de 2003, colocou, de maneira bastante objetiva, que a política de humanização tem:

- Valorização da dimensão subjetiva e social em todas as práticas de atenção e gestão no SUS

- Fortalecimento de trabalho em equipe multiprofissional;

Apoio à construção de redes cooperativas, solidárias e comprometidas com a produção de saúde e com a produção de sujeitos:

- Co-responsabilidade desses sujeitos nos processos de gestão e atenção;

- Fortalecimento do controle social com caráter participativo; e

- Compromisso com a democratização das relações de trabalho e valorização dos profissionais de saúde

Com a implementação desta política, foram trabalhadas quatro marcas a serem consolidadas:

- Redução das filas e tempo de espera com ampliação do acesso e atendimento acolhedor e resolutivo baseados em critério de risco: 
- Todo usuário do SUS deve saber quem são os profissionais que cuidam de sua saúde e os serviços de saúde se responsabilizam por sua referência territorial;

As unidades de saúde devem garantir a informação ao usuário, o acompanhamento de pessoas de sua rede social e os direitos do código dos usuários do SUS;

As unidades de saúde devem garantir gestão participativa aos seus trabalhadores e usuários e educação permanente aos trabalhadores.

Como estratégia geral, a política nacional de humanização coloca vários eixos de ação:

No eixo das instituições do SUS, busca-se que a Política Nacional de Humanização faça parte do Plano Nacional, dos Planos Estaduais e Municipais dos vários governos;

no eixo da gestão dos trabalhos, busca-se a promoção de aç̃es que assegurem a participação dos trabalhadores nos processo de discussão e decisão, com o objetivo de fortalecer e valorizar os trabalhadores, sua motivação, auto-desenvolvimento e crescimento profissional;

no eixo do financiamento, busca-se integração de recursos vinculados a programas específicos de humanização:

no eixo da atenção, busca-se uma política incentivadora do protagonismo dos sujeitos e da ampliação da atenção integral à saúde

no eixo da educação permanente, busca-se que a Política Nacional de Humanização componha o conteúdo profissionalizante na graduação, pós-graduação e extensão em saúde, vinculando-a aos polos de Educação Permanente e às instituiç̃̃es de formação:

no eixo da informação e comunicação, busca-se a inclusão da Política Nacional de Humanização no debate da saúde; e

no eixo da gestão da Política Nacional de Humanização, busca-se o acompanhamento e avaliação sistemáticos das ações realizadas, estimulando a pesquisa relacionada às necessidades do SUS na perspectiva da humanização.

Como parâmetros de acompanhamento de sua implementação buscaram-se:

Na atenção básica: elaboração de projetos de saúde individuais e coletivos para usuários e sua rede social; incentivo às práticas promocionais da saúde; formas de acolhimento e inclusão do usuário, que promovam a otimização dos serviços, o fim das filas, a hierarquização de riscos e o acesso aos demais niveis do sistem.

Na urgência e emergência, nos pronto-socorros, pronto-atendimentos, assistência pré-hospitalar e outros: demanda acolhida, através de critérios de avaliação de risco, garantindo o acesso referenciado aos demais níveis de assistência; garantia de referência e contra-referência, resolução da urgência e emergência, provindo o acesso à estrutura hospitalar e a transferência segura conforme a necessidade dos usuários: e definição de protocolos clínicos, garantindo a eliminação de intervenções desnecessárias e respeitando a individualidade do sujeito.

Na atenção especializada: garantia de agenda extraordinária em função da análise de risco e das necessidades do usuário; critérios de acesso; otimização do atendimento aos usuários, articulando a agenda multiprofissional em ações diagnósticas e terapêuticas, que impliquem diferentes saberes; e definição de protocolos clínicos, garantindo a eliminacão de intervenções desnecessárias.

Na atenção hospitalar: foram estabelecidos dois níveis crescentes - B e A - para adesão à Política Nacional de Humanização.

Parâmetros de nível B: existência de Grupos de Trabalho de Humanização com plano de trabalho definido; garantia de visita aberta, através da presença do acompanhante e de sua rede social; mecanismos de recepção com acolhimento aos usuários; mecanismos de escuta para a população e trabalhadores; equipe multiprofissional (ao menos médico e enfermeiro) de atenção à saúde para seguimento dos pacientes internados, com horário pactuado para atendimento à família ou sua rede social; existência de mecanismos de desospitalização, visando alternativas às práticas hospitalares como as de cuidados domiciliares; garantia de continuidade de assistência com sistema de referência e contra-referência.

Parâmetros de nível A: Grupo de trabalho de Humanização com plano de trabalho implantado: garantia de visita aberta; ouvidoria funcionando; equipe multiprofissional (ao menos médico e enfermeiro) de atenção à saúde para seguimento dos pacientes internados e com horário pactuado para atendimento à família ou sua rede social; existência de mecanismos de desospitalizacão visando alternativas às práticas hospitalares como as de cuidados domiciliares; garantia de continuidade de assistência com sistema de referência e contra-referência; Conselho Gestor Local com funcionamento adequado; existência de acolhimento com avaliação de risco nas áreas de acesso; e plano de educação permanente para trabalhadores com temas de humanização. 
Até então, a Política Nacional de Humanização tratou a questão da humanização de forma muito mais voltada para as relações interpessoais que dos espaços físicos. Com este foco de atuação, a Política trata a questão da Ambiência.

Ambiência na saúde refere-se ao tratamento dado ao espaço físico entendido como espacco social profissional e de relaçães interpessoais que deve proporcionar atenç̧ão acolhedora, resolutiva e humana. ${ }^{23}$

O conceito de ambiência, no entendimento do Ministério da Saúde, segue três eixos que devem estar sempre integrados na composição do ambiente: o espaço que visa à confortabilidade: o espaço que possibilita a produção de subjetividades; e o espaço usado como ferramenta facilitadora do processo de trabalho (otimização de recursos, atendimento humanizado, acolhedor e resolutivo).

Existem componentes que atuam como modificadores e qualificadores do espaç, estimulando a percepção ambiental e, quando utilizados com equilibrio e harmonia, criam ambiências acolhedoras propiciando contribuiç̣ões significativas no processo de produção de saúde. ${ }^{24}$

A ambiência pode ser uma importante ferramenta que propicia a mudança no processo de trabalho, desde que não seja discutida isoladamente, uma vez que ela se relaciona com a postura e o entendimento desses processos e práticas já instituídos e adotados na rotina pelos trabalhadores e gestores.

Outro fator importante para sua utilização eficiente é a interface com outros dispositivos da Política Nacional de Humanização.

Com relação à Atenção Básica, os espaços precisam ser pensados de forma que estimulem a integração das equipes de trabalho através da criação de áreas que possam ser compartilhadas pelas equipes, como, por exemplo, os espaços de acolhimento de entrada, as áreas de encontros entre trabalhadores e entre trabalhadores e usuários.

Relativamente ao dispositivo Visita aberta, vale colocar a incorporação nos projetos, de espaços que sejam capazes de acolher os visitantes, como por exemplo espaços de espera; o conceito que permita ao visitante ou acompanhante fácil acesso a sanitários e bebedouros; até mesmo espaços que permitam ao utente, em condições, receber visitas fora do leito.

Quando se coloca o dispositivo Direito a acompanhante, pode-se buscar que existam espaços capazes de acolhê-lo nos diversos ambientes das unidades (pronto-socorros, centro cirúrgicos, UTIs, etc.) e também ter espaços que permitam momentos de encontros, diálogos, relaxamento e entretenimento, como assistir televisão ou ouvir música.
Com relação à informação, sinalização e acessibilidade, os ambientes devem contemplar projetos de sinalização e placas de informaç̃oes de toda ordem que tenham linguagem clara e representativa. As sinalizações devem conduzir os usuários que estejam a caminho dos equipamentos de saúde.

Quando se pensa o trabalhador nos serviços de saúde, é importante que as áreas de apoio para o trabalhador estejam bem localizadas, seja em número suficiente e para todos os profissionais. As áreas de apoios e serviços de apoio, além de adequadas funcionalmente, devem propiciar espaços de trabalho prazerosos.

Quando a questão é acolhimento, pressupõe-se a criação de espaços de encontros entre os sujeitos, espaços que permitam a interação entre usuários e trabalhadores, entre trabalhadores e trabalhadores e entre os próprios usuários, que sejam acolhedores também no sentido de conforto, produzindo pela introdução de vegetação, iluminação e ventilação naturais, cores, artes e demais questões já mencionadas. Também vale colocar a utilização de mobiliários que sejam confortáveis e suficientes e que estejam dispostos de maneira a promover interação entre os usuários, além de equipamentos que permitam a informação ao usuário em espera.

No âmbito do pronto-socorro, é importante que se tenham propostas arquitetônicas com um arranjo que esteja de acordo com o arranjo proposto na atenção e que auxilie na resolutividade do atendimento e da organização do processo de trabalho dentro desses setores de urgência e emergência.

Além de todos esses conceitos colocados para a Política Nacional de Humanização, vale lembrar que há inúmeros projetos paralelos e complementares que visam a humanização, como por exemplo a proposta "Visita Aberta e Direito a Acompanhante, o programa "Humanização do Parto: Humanização no Pré-Natal e Nascimento" ou mesmo o "Prêmio HumanizaSuS David Capistrano" que visa reconhecer as experiências que dignificam a saúde pública e que valorizam o usuário e o trabalhador da saúde.

\subsection{Humanização}

Humanização: um conceito tão utilizado e veiculado na área arquitetônica, consciente ou inconscientemente, porém de difícil definição.

Arquitetura e humanização estão, ou deveriam estar, intimamente ligadas não só conceitualmente. 
mas também na prática. O mais importante em termos de concepção de espaços arquitetônicos é a sua adequação ao usuário, ao ser humano que os utilizará.

A edificação deve atender a uma série de anseios materiais e psicológicos dos seus ocupantes, sendo imperioso, portanto, que a construção reúna as qualidades minimamente necessárias para que sejam atendidas as condições básicas de segurança, de saúde, de higiene e de bemestar dos usuários.

O que torna um ambiente 'humanizado' são atributos que Ihe conferem escala e características compatíveis com as dimensões fisiológicas, psicológicas e morfológicas que o indivíduo carrega em si, assegurando alguma capacidade que este ambiente tem de interagir de maneira benéfica, agradável com o seu usuário. Onde quer que o ser humano esteja, em uma casa popular, em um apartamento, em um escritório, em um consultório ou em um hospital, qualquer que seja este ambiente, se ele interagir positivamente com seu usuário, pode-se entendê-lo como sendo um ambiente humanizado.

Partindo-se para a arquitetura hospitalar, que é o foco desta pesquisa, pode-se entender que este conceito ganha contornos mais restritos. Mas, de qualquer maneira, o seu sentido sempre será o mesmo: interação positiva entre ser humano e ambiente. Importante salientar que "... curar é diferente de cuidar. O cuidado com o paciente é tão importante quanto a sua cura, muitas vezes não alcançada"25. Quando se pensa nestes termos, "cuidar" explica melhor que "curar" o que enfatizamos como interação entre indivíduo e ambiente.

\section{TOLEDO coloca muito bem a importância da humanização nos ambientes hospitalares:}

Em geral, é nesse edifício que nos conscientizamos de nossas fragilidades, impotências e solidão diante da doença, e tambeem que podemos vir a encontrar a coragem, a solidariedade e a esperança necessárias ao processo de cura. A humanização do edifício hospitalar é condição imprescindível para que esses sentimentos positivos floresçam, ajudando-nos a superar o estresse, a mitigar a dor e a abreviar o momento da alta. 26

O termo humanização é de difícil definição, mas, tomando como simples exemplos as colocaç̃es citados acima, talvez se comece a entendê-lo: qualquer espaço exerce influência sobre o ser humano, seja ele sua residência, seu local de trabalho, de lazer etc. O que torna estes espaços humanizados é o fato de eles estabelecerem uma forte e boa ligação com o seu usuário. No caso dos ambientes hospitalares, este aspecto deve ser mais forte ainda, pois os espaços são projetados para receber pessoas geralmente em estágio de recuperação, onde o fator emocional muito influi. Sendo assim, o ambiente deve propiciar ao indivíduo, sensação de bem-estar e tranquilidade, o que, consequentemente, Ihe proporcionará a sensação de segurança e confiabilidade.
Segundo SAMPAIO, em sua tese de doutorado, existem vários estudos que comprovam o beneficio de ambientes mais humanos na recuperação de pacientes, evidenciando por isso a importância da humanização:

...primeiramente o paciente é uma pessoa que pelas suas condições físicas e psicológicas tem as seguintes sensacões expectativa ansiedade desconfiança insegurança desânimo tristeza e medo Por estar na maior parte das vezes imóvel o seu sentido visual, auc (a)

Seguindo a mesma linha de raciocínio, MEDEIROS diz em sua dissertação de mestrado em psicologia que "a humanização aparece como tentativa de resgate da condição de sujeito como ser integral e de uma nova concepção do processo saúde-doença, o que inclui a preocupação com os significados atribuídos ao adoecer." ${ }^{28}$ e inicia uma conceituação:

[... a humanização hospitalar envolve - ou pelo menos deveria envolver - elementos relativos ao atendimento e ao espaço físico, estando entre os primeiros a relação estabelecida entre o profissional de saúde e os pacientes, e entre os segundos, a ambientação do edifício e o seu paisagismo.

Vejam-se os comentários feitos por pacientes, personagens do documentário de CROMBIE: "É uma ironia cruel que, justo quando nos sentimos mais vulneráveis, travamos contato com um dos tipos mais frios e duros de arquitetura..." (CROMBIE, 2008). "Os longos corredores em hospitais são muito assustadores para mim..." (CROMBIE, 2008). "Você se sente desorientando, não tem certeza de onde está..." (CROMBIE, 2008). Neles percebe-se que os ambientes hospitalares, em sua maioria, desmentem os aspectos mais objetivos deste conceito, isto é, "a teoria, na prática, é outra". E isso é algo que deve ser combatido, pois seus efeitos nos pacientes, se não são maléficos, também não cumprem seu papel, auxiliando na sua recuperação, conforme sugere novamente SAMPAIO: "Um ambiente hospitalar humano deve ser confortável, transmitir bemestar e propiciar um padrão satisfatório de qualidade para todos os seus usuários, sem exceção"30

Estas citaç̃oes de SAMPAIO e MEDEIROS e os comentários feitos no documentário de CROMBIE conduzem ao mesmo ponto de vista: a humanização tem papel importante na recuperação do paciente e mais, reforçam a idéia de que o termo humanização é o conceito que dá ao ambiente a garantia de que ele influenciará no ser humano que o utilizar, de maneira benéfica, aumentando, assim, suas condições de melhora.

Como cita MEDEIROS:

-ambientes com potencial terapêutico 'ou 'elementos de design que promovam saúde'. Tratam-se dos elementos presentes na própria organizaç̃ão espacial e ambientação do edificio que beneficiam o paciente durante a internaç̃o ou alsum tipo de procedimento realizado ${ }^{31}$ 


\subsection{Arquitetura para estabelecimentos assistenciais de saúde}

Que a arquitetura tem papel fundamental no sucesso ou não de um estabelecimento assistencial de saúde é fato, pois a arquitetura, porque constitui o processo que permite o planejamento de todo o complexo contexto, tem a capacidade de levantar, analisar e trabalhar as necessidades para cada edificação em questão. Através da arquitetura pode-se visualizar toda a problemática envolvida e equalizá-la a ponto de permitir a construção de ambientes adequados a cada situação.

Quando da discussão sobre "humanização" a arquitetura sempre tem que ser voltada para o ser humano e. no caso dos espaços assistenciais de saúde, ela tem maior importância ainda. pois ela se volta para o ser humano talvez em sua condiç̃a de maior sensibilidade, como coloca REMEN:

Segundo Remen (1993 apud MEDEIROS; LUCIANA DE, 2004, p. 33), saúde é o equilibrio das dimensões mente-corpo-sentimento e requer uma vida com qualidade, calor, amizade, proposito, humor e esperança. A ruptura desse equilibrio, aliado às escolhas e usos que são feitos do nosso corpo, afeta os três aspectos da pessoa e ocasiona a doença, seguida de dor e sofrimento próprios de cada um. Em oposição semelhante, Santos e Sebastiani (2001, p.150 apud MEDEIROS:LUCIANA DE, 2004, p. 33) apontam que é '( ) a desarmonia orgânica ou psíquica que, através de sua manifestacão, quebra a dinâmica de desenvolvimento do individuo como um ser global gerando desarmonizacão da pessor: compreende se esse desequil'brio como um abalo estrutural na condiç̃o do ser dentro da sua sociocultur ${ }^{32}$

A partir desta constatação, PINTO salienta que "O hospital como um todo tem como princípio básico a proteção ao paciente.." ${ }^{\prime 3}$. O hospital tem que ser e parecer seguro para dar ao paciente a sensação de confiança que ele precisa para se recuperar.

Segundo a RDC $50^{34}$, a definição de hospital é a seguinte:

Hospital - estabelecimento de saúde dotado de internação, meios diagnósticos e terapêuticos, com - objetivo de prestar assistência médica curativa e de reabilitacão, podendo dispor de ativida a

as, na verdade, hospital vai muito além dessa definição: hospital é o lugar que tem que oferecer ao paciente todas as condições necessárias para ele se tratar, se recuperar e retornar à sua vida normal o mais rapidamente possível. É muito mais que dar assistência programada por um período. Hospital é o espaço arquitetônico que visa além de atender às questões básicas necessárias - conforto ambiental, racionalização da circulação, segurança etc. -, permitir a melhor realizaç̃o dos procedimentos médicos e auxiliar na melhora da relação entre paciente equipe médica, infuenciando assim, de maneira benéfica, a recuperação do paciente. 0 conceito desses estabelecimentos vem evoluindo e a sua objetivação física vem buscando cada vez mais a eficiência funcional dos edifícios, conforme a citaç̃a de Lee:

De acordo com Lee (1977 apud MEDEIROS; LUCIANA DE, 2004, p. 56), os estudos sobre o impacto do ambiente físico do hospital no comportamento dos pacientes, revelaram meios de oferecer melhorias aos ambientes pouco atrativos, monótonos e sombrios, com repetições de elementos como portas janelas e desenhos de piso. Além disso, trouxeram à tona diferentes problemas da própria cultura médica e de estrutura ambiental do edificio que acabam desencadeando um funcionamento ultrapassado da instituição. ${ }^{36}$

Ainda tratando da mesma questão, temos a observação de SAMPAIO quanto à influência que o ambiente tem na qualidade do atendimento em vários aspectos:

O arquiteto pode colaborar para minimizar o desconforto destes ambientes, geralmente frios, impessoais com cheiros e rú́dos peculiares, pessoas sofrendo e profissionais agitados, projetando meios de descanso, tranquilidade, relaxamento, que permitam que o paciente se sinta mais confiante e que tenha condições de se recuperar mais rapidamente e por sua vez, que também propiciem à equipe de profissionais um local de trabalho que possibilite um atendimento de melhor qualidade, resultando em um maior rendimento, mais produtividade, segurança e, o mais importante, que este profissional desempenhe melhor a sua função, com satisfação. ${ }^{37}$

Entendendo desta maneira a importância da harmonia entre ambiente e os demais requisitos necessários para a recuperação do paciente, começa-se a traçar uma concepção mais clara do papel da arquitetura nesses ambientes. TOLEDO foca esta questão de maneira bastante eloquente

.... ambiente hospitalar certamente pode ser um facilitador e mesmo um estimulador de práticas que considerem a auto-estima dos pacientes como um fator de cura. Nesse sentido, acreatiamos que os arquitetos precisam posicionar-se como protagonistas desse processo, recusando o papel de meros coadjuvantes, cujo encargo seria apenas o de projetar ambientes definidos em programas hospitalares desenvolvidos, feitos, em sua maioria, sem sua participação.

Trata-se portanto de recuperar o papel e a responsabilidade de proporcionar, por meio da arquitetura, as condiç̃eses funcionais e de conforto necessárias ao bom desempenho das práticas médicas, bem como o bem-estar e a auto-estima dos usuarios dos edificios de saúde. Atuando assim, os arquitetos certamente contribuirão para o processo de cura dos pacientes. ${ }^{38}$

A partir de então, vislumbra-se uma ampla abrangência da prática em arquitetura, com ferramentas adequadas para se alcançar melhores resultados em termos de concepção de espaços hospitalares, como, por exemplo, em relação à questão do conforto térmico, conforme salienta FROTA e SCHIFFER:

${ }^{32}$ REMEN (1993 apud MEDEIROS, 2004, p. 33), ${ }^{33}$ PINTO (1996, p. 87) 
À arquitetura cabe tanto amenizar as sensaçõos de desconforto impostas por climas muitos rígidos, tais como os de excessivos calores frios ouventos, como também propiciar ambientes que sejam, no mínimo. tão confortáveis como os espaços ao ar livre em climas amenos. ${ }^{39}$

Também começa a ficar mais claro o quão complexa é a concepção de um ambiente assistencial de saúde pois "Pensar os espaços de um hospital é considerar até 120 tipos diferentes de atividades a serem realizadas ao mesmo tempo, 24 horas por dia, pelos mais diversos funcionários - [..] - sem se esquecer da circulação dos pacientes." (GEROLLA, 2007, p. 66).

Desta maneira, entende-se o porquê de KARMAN e PINTO salientarem a importância do projeto e do planejamento quando da concepção desses ambientes.

Segundo KARMAN:

A arquitetura, manutenção preditiva, arquitetura de manutenção ou manutenção orgânica origina-se. como as demais, na prancheta ou na tela do computador e destina-se a incorporar à futura instituição requisitos arquitetênicos construtivos, de instalação e de funcionamento, capazes de viabilizar. facilitar e tornar econômica racional sesura a futura manutenç̃o do hospital 40

A fase de pré-planejamento e de interplanejamento caracteriza-se pela disponibilidade e correto emprego de dados, informações, levantamentos, pesquisas, programa de necessidades, conhecimento do funcionamento e de utilização, particularidades e outros; neste contexto representa importante

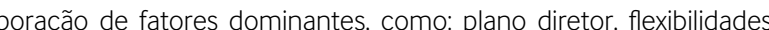
previsão de expansão, percursos, fluxos segregados e outros. ${ }^{41}$

Segundo PINTO, o planejamento também é importante, conforme se pode ver na citação seguinte:

O planejamento é essencial para a criação de um hospital ou de toda uma rede de unidades e a falta de um planejamento adequado tem sido a causa do surgimento desordenado de hospitais que não atendem às necessidades da populaç̃o a que se destinam. ou não têm possibilidade de serem conclúdos ou mantidoss

Complementando estes argumentos, SAMPAIO acrescenta mais variavéis à questão do planejamento como clima, topografia, insolação, condições ambientais etc, conforme vemos na citação seguinte:

O projeto de um ambiente hospitalar, mais do que qualquer outro tipo de projeto deve ser desenvolvido considerando-se: o clima onde ele será inserido, a insolação, a topografia local, as condições ambientais e paisagísticas; o programa com toda a sua complexidade e as diversas especialidades; a sua flexibilidade e expansibilidade: a seguranca: eficiência no desenvolvimento das atividades; adaptabilidade a novas descobertas e tecnologias e a satisfacãõo e bem-estar dos seus usuários. ${ }^{43}$
Através destes comentários, percebe-se a complexidade do assunto 'arquitetura' quando relacionado ao estabelecimento assistencial de saúde. Complexidade não somente conferida pelo complexo aparato técnico que envolve o funcionamento de uma instalação hospitalar, mas principalmente por se tratar de uma arquitetura que não pode dar-se o luxo de não relevar seu usuário, devendo, necessariamente, voltar-se para o paciente e assim assumir a responsabilidade de poder, ou não, ajudar na sua recuperação.

Nos exemplos práticos com os quais se deparou na bibliografia, em especial os de Lelé - João Filgueiras Lima - e Rino Levi, identificou-se uma série de requisitos, objetivos ou subjetivos, necessários para se atingir uma boa e eficiente arquitetura nesses edifícios. Tais requisitos, na verdade, são básicos e necessários para se atingir o sucesso em sua utilização. Eles impõem, ja nos termos de elaboração do programa, que a qualidade de seus atributos não faça diferenca entre segmentos do público que o utilizará - o que aparece, já de início, como fundamental para sua eficiência, isto é, seria como se se imaginasse, a par de uma perspectiva de atendimento universal à saúde, também um programa de necessidades arquitetônicas que se pautasse como uma "arquitetura universal". Mas, obviamente, quando se fala em requisitos mínimos e básicos, entende-se que estes precisam ser, por pressuposto, universais. Por outro lado, devem ser plurivalentes, isto é, passíveis de serem aproveitados para garantir a qualquer edificio sua eficiência. No caso dos hospitais, há outros itens a serem considerados, tais como serviços hotelaria, decoração, utilização de equipamentos atuais (TVs, ar condicionado, camas com controles eletônicos), etc, mas esses requisitos sequer são colocados em pauta por se tornarem supérfluos diante da importância do requisito de universalidade.

De modo geral, os principais requisitos básicos a serem tratados são: adequação do edifício ao local onde será implantado, tanto técnica quanto sócial e culturalmente falando; estudo funcional do problema quando da elaboraç̃ão do projeto; agrupamento de usos e atividades afins tanto para racionalizar o uso, quanto para minimizar custos; auxílio na prevenção à infecção hospitalar através de artifícios de projeto; racionalização das circulações; flexibilidade dos ambientes; preocupação com o conforto ambiental, através da iluminação natural e artificial, ventilação também natural e artificial, utilização de cores, som e água; presença do verde no ambientes, através do paisagismo, relação entre interior e exterior e humanização dos espaços.

Obviamente, há muitos outros requisitos que precisam e devem ser analisados, quando da elaboração dos projetos, mas estes, aqui relacionados, devem ser privilegiados, não somente porque funcionam como base para os demais, mas principalmente porque são requisitos que influenciam na qualidade do ambiente e consequentemente influenciam na qualidade oferecida aos usuários e aplicada na recuperação dos pacientes.

${ }^{39}$ FROTA (et al., 2003, p.53), ${ }^{40}$ FROTA (et al, 2003, p. 22)

${ }^{41}$ Ibidem, p. $54,{ }^{42}$ PINTO (1996, p. 154), ${ }^{43}$ SAMPAIO (2004, p. 154) 


\subsubsection{Requisitos Básicos}

\section{A - Adequação ao local}

Este é o primeiro requisito a ser atendido, até mesmo porque é o primeiro passo a ser dado quando a intenção é a construção de um espaço voltado para o atendimento de saúde, já que é pela escolha do terreno que devem ser iniciado os procedimentos de elaboração de projeto, conforme saliente BITTENCOURT:

Os critérios relativos ao clima, insolação, acessibilidade, entre outros fatores, devem determinar a escolha do local para a construção do edificio. l... E preciso que o espaço em que está situado o hospital esteja ajustado ao esquadrinhamento sanitário da cidade. É no interior da medicina do espaço urbano que deve ser calculada a localização do hospital [..., é preciso não somente calcular sua localização, mas a sua distribuição interna de seu espaço.

TOLEDO coloca muito claramente as preocupaç̃oes primordiais quando da implantação do estabelecimento assistencial de saúde, ressaltando a importância do planejamento rigoroso quanto à localização da edificação, bem como da importância da presença do arquiteto no processo, contribuindo com seus conhecimentos urbanísticos e de planejamento:

A escolha do local onde será implantado o hospital deve resultar de um esforço de planejamento, cujo principal objetivo é inserir, com sucesso a nova unidade na rede de saúde em funcionamento. Assim, para localizar onde o hospital será mais necessário, deve-se levantar e analisar, entre outros dados, a composição da população, o quadro nosológico, e a oferta de leitos e serviços e os respectivos déficits existentes.

A formaç̃a urbanística do arquiteto é preciosa neste momento, tanto para a espacializaç̃ão da rede quanto para a seleção e a escolha final dos terrenos onde serão erguidos os hospitais. Com o apoio do arquiteto, poderão ser evitados diversos problemas, entre os quais eventuais conflitos com as tendências de expansão da cidade ou com a proximidade de usos incompatíveis com a função hospitalar (cemitérios, aterros sanitários, fábricas etc.

A presença do arquiteto contribui ainda para evitar que a unidade hospitalar seja construída em loca sem infra-estrutura ou em terrenos com área inferior à necessária para futuras expansões. A avaliação da topografia, das características do solo, do recobrimento vegetal existente, da insolação, dos ventos dominantes e das condições de acessibilidade são, entre outros aspectos, pontos a serem considerados pelo arquiteto na escolha do terreno. ${ }^{45}$

Independentemente dos requisitos específicos dos estabelecimentos assistenciais de saúde a serem atendidos, o respeito às normas municipais e à legislação local precisam também ser respeitadas - tais como análise da adequação ao plano diretor etc. Porém, o que precisa ficar claro é que somente $o$ atendimento a estas normas não é suficiente para garantir uma adequaç̃o eficiente ao local, pois estas tratam muito mais das questões de gabarito, área construída, recuos etc., do que da preocupação com a obtenção da qualidade em si. Já as normas relacionadas à ANVISA (Agência Nacional de Vigilância Sanitária) são mais específicas e realmente buscam maior qualidade dos ambientes. Estas, porém, serão objeto de discussão específica.

Infelizmente, a realidade nos mostra que esta preocupação com a adequação ao local não é tratada como 'condição necessária' e efetivamente pouco acontece na prática, como comenta PINTO:

É muito comum uma instituição ou grupo de profissionais pretender a implantação de um hospital em determinada comunidade com um número de leitos preestabelecidos sem que, no entanto, tenha sido realizado qualquer estudo ou levantamento referente àquela localidade, de modo que venha justificar implantação daqueles leitos e até mesmo, de necessidade daquela unidade. ${ }^{46}$

A adequação do estabelecimento de saúde ao local não deve somente obedecer a critérios específicos de implantação, como topografia, dimensionamento etc., mas também considerar todo o seu entorno, em harmonia com a infra-estrutura existente no local. Por exemplo: a rede de serviços existente (infra-estrutura, transportes, abastecimento etc.), os aspectos sócioeconômicos, a dotação de equipamentos públicos em geral, acessibilidade, entre outros. Uma unidade hospitalar, ao ser implantada, deve estar perfeitamente integrada à rede de serviços de sua região, conforme coloca PINTO:

Assim, antes de se desenvolver qualquer empreendimento voltado para a implantacăo de leitos. É necessário que sejam realizados estudos de diagnóstico relacionados aos diversos aspectos do planejamento em saúde como a estrutura demográfica a configuracão migratória os aspectos socioeconômicos, geográficos, epidemiológicos e outros, que devem ser analisados com o objetivo de se

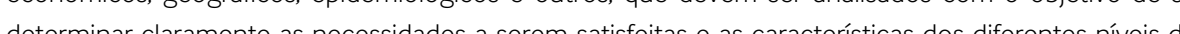
complexidade dos senicos a serem prestados 47

É necessário, também, identificar o que existe na região em termos de suporte médico, atendimento à saúde etc., tanto nos aspectos quantitativos como nos qualitativos, pois é importante uma perfeita adequação à realidade dos serviços instalados para se evitar conflitos e superposições desnecessárias - o que pode colocar em risco a viabilidade tanto do empreendimento em instalação quanto dos já instalados. Novamente, auxiliados pelas consideracõos de PINTO:

imprescindivel o conhecimento das condiç̃es médico-sociais da área de abrangência da unidade pretendida, observando-se o tipo de assistência nas unidades já existentes, os equipamentos médicos disponíveis nessas unidades, o pessoal qualificado para o seu funcionamento e os diversos órgãos assistenciais destinados ao atendimento de sua população ${ }^{48}$ 
Importante salientar que não só a integração do estabelecimento ao local é importante: quando possível, é recomendado que o próprio terreno a ser escolhido seja cuidadosamente avaliado antes da definição do empreendimento, pois é fato que a escolha acertada do terreno em muito contribui com a possibilidade de o empreendimento agregar eficiência. PINTO esclarece na citação a seguir:

O planejamento das unidades de saúde começa muito antes dos estudos para a edificação propriamente dita. Inicia-se na própria escolha do terreno, onde a observaçăo do seu entorno e primordial para uma localização adequada. Problemas de sujeira, insetos, ruídos, poeira, proximidade de terrenos alagados, rios polúídos, etc, são aspectos negativos que podem concorrer para aumentar os riscos de contaminação dentro dos hospitais. ${ }^{49}$

A escolha do local para implantação de uma unidade de saúde, notadamente quando envolve o leito hospitalar, terá importância fundamental em seu planejamento e funcionamento futuro. Um pequeno engano no planejamento ou na construção pode, muitas vezes, ser contornado, porém um erro de seleção do terreno não pode ser corrigido após a conclusão da obra. Assim sendo, deverão ser observadas questões relacionadas à topografia, tipo de solo, drenagem, movimento de terra e à orientaç̃o do edifício. 0 conhecimento especializado dessas questões resultará em grande economia para a construção.

ROSENFIELD, embora tenha escrito seu livro "Hospital: Integrated Design" em 1950, coloca ponderações que nos dias atuais são bastante pertinentes, no que ser refere à realidade dos estabelecimentos assistenciais de saúde. E, com sua maneira bastante simples e didática, apresenta insumos que podem resumir tudo que se colocou até o momento, relativamente ao assunto, conforme mostram as citações a seguir:

A razão para consultar um arquiteto (e até mesmo, quando indicado, o administrador também) antes de escolher o local onde o prédio será construído é simplesmente porque ele the garante sugestões e conselhos profissionais num passo basicamente importante.

A consideração mais importante na escolha da localização urbanística para o hospital é ter um terreno convenientemente suportado pelos mais baratos e mais acessiveis meios de transporte. Hospitais devem ser acessíveis não somente por pacientes, mas também por médicos, enfermeiros, visitantes, suprimentos, bombeiros etc. ${ }^{52}$

Além de todos esses aspectos, vale ressaltar também que a perfeita adequação do estabelecimento ao local, permite o máximo aproveitamento de suas condições de conforto ambiental, o que é fundamental para o funcionamento do estabelecimento. Porém, ta aspecto será novamente abordado quando da análise dos requisitos ligados à preocupação com o conforto ambiental.

${ }_{59}^{49}$ bidem, p. 109

${ }_{50}^{50}$ Ibidem, . . 45

5 ROSENFIELD (1950, p.30)

52 lbidem $P 30$

\section{B - O Projeto deve resultar de um estudo funcional e técnico do problema}

Um estudo funcional e técnico do problema significa entender que vocação se espera de um determinado projeto, estabelecida essa vocação a partir do diálogo com profissionais da área de saúde (médicos e administradores), considerados como integrantes da equipe de desenvolvimento.

Por exemplo, quando é projetado um hospital pediátrico, o estudo funcional e técnico é bastante diferente do estudo funcional de um hospital de tratamento de câncer. É a partir deste raciocínio que trabalharam Lelé, no desenvolvimento dos projetos da Rede Sarah, e Rino Levi, em todos os projetos hospitalares que desenvolveu. Sempre analisaram a questão em profundidade, tendo aos seus lados profissionais da área de saúde, adequados conforme as demandas de cada situação.

O expediente de se envolver no desenvolvimento do projeto dos ambientes assistenciais de saúde uma equipe multidisciplinar torna-se fundamental, conforme comenta TOLEDO:

Com efeito, tal prática possibilita a troca permanente de saberes entre os profissionais de saúde e os demais colaboradores, entre os quais arquitetos e designer, cuja contribuição tem sido fundamental equipamentos médicos utilizados pela Rede ${ }^{53}$

Lelé é o melhor exemplo de que, na prática, este procedimento torna-se uma receita de eficiência, sucesso do empreendimento e sua consequente transformação em referência. Mais que isso, uma análise expedita dos hospitais da Rede Sarah, de Lelé, embora todos eles tenham a mesma função - ortopedia - nos faz perceber que as unidades são bem diferentes umas das outras, pois cada situação de implantação requer um cuidado diferente. Esta singularidade que se verifica nas situaç̃̃es de implantação e nas características arquitetônicas resulta da equilibrada simbiose entre a preocupação com a adequação ao local - principalmente com relação ao conforto ambiental - e o estudo funcional e técnico do problema.

Jarbas Karman é bastante objetivo nesta questão, como se pode ver nas citaç̃̃es a seguir, onde ele defende a importância do planejamento, de levantamentos, de pesquisas e também um trabalho em conjunto com outros profissionais, formando uma equipe multidisciplinar resumindo, de maneira bastante objetiva, o que deve acontecer com o projeto de uma unidade assistencial de saúde: "É a conscientização da concepção: 'Faça certo da primeira vez', de Eduard Demming". ${ }^{54}$ 
A fase de pré-planejamento e de interplanejamento caracteriza-se pela disponibilidade e correto emprego de dados, informaç̃es, levantamentos, pesquisas, programa de necessidades, conhecimento do funcionamento e de utilização, particularidades e outros; neste contexto representa importante previsão de expansão, percursos, fluxos segregados e outros. . $^{5}$

O físico encontra-se intimamente vinculado ao funcional; o planej mento arquitetônico, ao administrativo. Arquitetura hospitalar, engenharia de manutenção, bioengenharia, engenharia clínica, informática, engenharia hospitalar, organizaç̃ão e administração hospitalar são meios, procedimentos e recursos que, juntamente com as atividades dos profissionais de saúde, visam viabilizar o objetivo comum: proteção, promoção e recuperação da saúde. ${ }^{.6}$

Da mesma forma, TOLEDO coloca a importância do planejamento desses edifícios, quando afirma ser "... elaboração do Plano Diretor Hospitalar, ferramenta imprescindível para a preservação da racionalidade e da funcionalidade do projeto original"57.

\section{C- Racionalização das circulações e agrupamento de usos e atividades afins}

Este quesito nada mais é que a preocupação com a racionalização do projeto como um todo. Em termos objetivos, se o problema das circulações é solucionado e se a distribuição e articulação dos ambientes assumem um agrupamento racional de usos, o projeto é todo racional.

Por agrupamento de usos, entende-se a organização funcional dos ambientes dentro do edifício de maneira que se tenha uma distribuição lógica e funcional, garantindo maior eficiência aos procedimentos, segurança, agilidade, economia e ainda contribua na prevenção à infecção hospitalar. Por exemplo, devem-se agrupar setores de procedimentos, tais como cirurgias, exames etc. Do mesmo modo, outros ambientes, como as áreas de permanência e recuperação de pacientes, devem estar agrupados de outra maneira, como por exemplo, áreas dos edifícios destinadas exclusivamente à internação, enquanto que o setor de emergência, de outra, privilegiando os acessos tanto de entrada de emergência quanto de acesso ao centro cirúrgico ou centro radiológico, por exemplo, e assim sucessivamente. Não é uma tarefa fácil fazer um agrupamento de usos eficiente e funcional, mas é vital para uma perfeita adequação do empreendimento.

De forma análoga, a racionalização das circulações deve ser criteriosamente buscada. Intimamente ligada ao agrupamento eficiente de usos, será esta circulação racional que garantirá uma perfeita harmonia e funcionalidade dos setores. As circulações podem ser divididas em: circulação restrita, de funcionários, de usuários, de material contaminado etc., tudo de maneira a permitir um perfeito e eficiente funcionamento do empreendimento, como coloca SAN JUAN: contribuição a observância e incorporação de fatores dominantes, como: plano diretor, flexibilidades

Um aspecto muito característico dos hospitais é a variedade de usuários presentes e suas diferentes necessidades ou expectativas, fato que pode ocasionar conflitos na forma de subgrupo (pacientes funcionários e visitantes) lidar com o espaço físico. ${ }^{58}$

Na atenção a este requisito, como mostram ANELLI, GUERRA \& KON na obra referente a Rino Levi, os projetos hospitalares elaborados por ele, se não são exemplos de eficiência, são exemplos da necessária preocupação com ela. Rino Levi elaborava desenhos da volumetria dos projetos hospitalares e através deles resolvia de maneira racional todo o agrupamento de usos e a circulação racional no edifício.

Desta maneira, pode-se entender claramente que $\mathrm{O}$ atendimento a estes requisitos é fundamental na questão da prevenção das infecções hospitalares e o projeto, adquirindo os atributos de racionalidade e eficiência nos usos dos ambientes, certamente obter-se-á um bom percentual de garantia deste controle.

\section{D - Auxílio na prevenção à infecção hospitalar}

"Segurança todo o hospital deve oferecer não só aos seus pacientes mas, também, aos funcionários que aí trabalham, contra possíveis fontes de infecção..."59

Partindo-se, então, do princípio que o arquiteto projetista tem fundamental responsabilidade no auxílio a prevenção da infecção hospitalar quando de sua atuação na realização do projeto - racionalizando circulações e agrupando usos de modo também racional - resta salientar alguns outros pontos importantes, dentre os inúmeros existentes, conforme ressaltam os autores pesquisados.

Obviamente, serão mencionados aqui os recursos de prevencão à infeccão, mas somente aqueles mais voltados para a questão física do edifício. Não caberia colocar a questão a partir, por exemplo, do modo como se realizam procedimentos etc., uma vez que não seria competência de um trabalho que trata do papel da arquitetura na humanização de ambientes hospitalares. Contudo, é importante ressaltar que são os procedimentos que orientam os fluxos e a distribuição de ambientes. Tal situação fica clara na citação de FIGUEIREDO:

Como a orientação para projetos de salas cirúrgicas, enfatizando a prevenção contra a infecção hospitala FIGUEIREDO (2001 apud SAMPAIO, ANA VIRGINIACARVALHÃES DE FARIA. p. 183) recomenda a divis̃̃o do

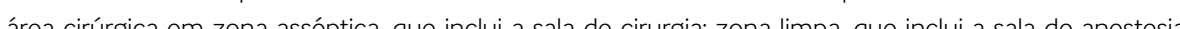

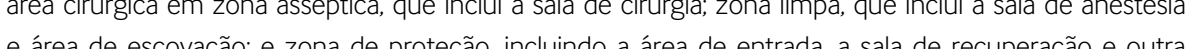
e area de esconaço e zona dicto

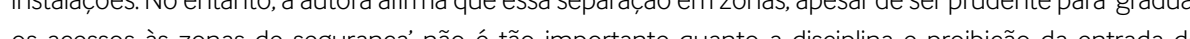
centrada de pessoas estranhas às áreas limpas. Quanto à separação dos corredores da entrada e sád́a, não é um ponto 
relevante no controle da infecção, e as bactérias da equipe médica, dos pacientes e dos equipamentos devem preocupar mais nas infecções pós-operatórias do que as bactérias carregadas em carrinhos ou macas. Portanto, a maior fonte de contaminação durante uma cirurgia é proveniente da equipe médica e as bactérias dispersas na pele são de maior importância do que as de trato respiratório. Portas fechadas durante um procedimento cirúrgico e a ventilação como pressão positiva sobre a mesa cirúrgica são maneiras eficientes ara evitar a infecção vinda de outras partes da sala e de outras salas contíguas. ${ }^{60}$

Quando se fala na prevenção à infecção hospitalar relativamente ao planejamento, PINTO salienta:

Uma vez definidos a escolha do terreno e os aspectos gerais de planejamento urbano, cabe apresentar soluções arquitetônicas capazes de oferecer à equipe de saúde as facilidades necessárias às suas atividades em ambientes adequados com áreas compatíveis e condiç̣̃es físicas que venham contribuir para a redução do risco de infeccão.

Como se sabe, a luz natural, solar, é uma das melhores fontes de prevenção à infecção hospitalar. Tratar-se-á deste assunto mais à frente, na parte de conforto ambiental. No entanto, comprovadamente, a prevenção à infecção hospitalar é uma das mais importantes funç̃oes da luz natural, sobre o que se tem a formulação de ROSENFIEL: no sentido mais exato do desenho do hospital, a boa luz natural é importante para os hospitais por três razões: é apropriada à visão, tem efeito psicológico e protege contra infecção.

Ainda há alguns pontos a serem ressaltados quando se refere às fontes de infeccão hospitalar. Pinto salienta: "É sabido, por dados comprovados em estatísticas internacionais, que as áreas do hospital que apresentam maior índice de contaminação e infecções cruzadas são a Lavanderia e a Central de Material e Esterilização..." ${ }^{\text {é2 }}$ MONTERO salienta a preocupação de Lelé com o sistema de ar condicionado:

0 ar condicionado é o grande veiculo das bactérias, tornando imprescindivel a manutenção de todos os dispositivos dos sistemas de ar condicionado. O novo hospital Sarah Rio de Janeiro prevê esse aspecto. Os dutos de ar condicionado, "de insuflamento", correm livres por cima da viga. Os dutos podem ser abertos para limpeza. Possuem uma tampa em cima, para sua manutencãa periódica. ${ }^{63}$

Vale colocar ainda que a dificuldade na prevenção à infecção hospitalar, embora seja assunto de corriqueira abordagem por parte dos Estabelecimentos Assistenciais de Saúde - EAS, ainda enfrenta obstáculos a serem superados, conforme colocam Fiorentini, Lima e Karman no texto Arquitetura na Prevenção de Infecção Hospitalar:

A arquitetura-Infecto-Preditiva, em sua luta por hospitais mais seguros, defronta-se com preconceitos tabus, costumes e tradições arraigados, nem sempre lastreados em suportes científicos, como hospitais pactuando com: salas de cirurgia séptica; bloco cirúrgico de corredor duplo; elevadores e monta-cargas privativos para transporte de material sujo; elevadores e monta-cargas privativos para transporte de

${ }^{60}$ FIGUEREEDO (http://wnw.bibliomed.com.br. Acesso em outubro de 200

61 PINTO (1996, p. 109)

63 lbidem, p.87)

ONTERO (2006, p. 156) material sujo; autoclaves verticais; ar condicionado de janela em áreas assépticas; repúdio a tubulão de descida de roupa suja e de resíduos sólidos; indiferença com relação a refluxo de ralos e a ocorrência de pressão negativa em rede de água potável, descaso com manutenção preventiva e aferição de manômetros e termômetros em equipamentos de esterilização: utilização de óxido de etileno sem 0 necessário conhecimento de causa: indevido uso e instalação de sistema de aspiração e outros. ${ }^{64}$

\section{E- Flexibilidade dos ambientes}

Evolução: é um conceito real que está intimamente ligado à questão da flexibilidade pois é a flexibilidade do objeto arquitetônico que possibilita sua evolução, sem limitá-la. Este raciocínio, principalmente quando ligado às questões práticas dos edifícios, torna-se fundamental. "As mudanças na sociedade e na medicina moderna progridem numa velocidade tal, que tornam as soluções de hoje inapropriadas para os problemas de amanhã.”.65

A constante evolução das técnicas e equipamentos hospitalares faz com que a construção física do ambiente permita alteraç̃oes conforme a evolução. 0 ambiente não pode limitar a evolução e a eficiência dos tratamentos e procedimentos, como salienta PINTO:

Considerando essas rápidas mudanças, tanto sob o ponto de vista tecnológico como gerencial, podemo observar que o planejamento de uma unidade hospitalar abrange uma vasta gama de atividades. das mais simples às mais complexas, de aspectos imediatos e a de longo prazo, o que implica no desenvolvimento de técricas construtivas adequadas. 0 importante é voltar o planejamento da unidade para adaptaçōes futuras, de tal modo que a mesma não venha a perder a sua identidade, tanto sob o aspecto organizacional como funcional. ${ }^{60}$

Essa capacidade de permitir a adequação do edifício de acordo com o desenvolvimento tecnológico e a evolução dos procedimentos médicos está nas mãos do arquiteto, segundo comenta TOLEDO:

As transformaç̃ões que ocorrem no edificio hospitalar a partir de usa inauguração decorren principalmente, do desenvolvimento tecnologico de que resulta um processo cada vez mais acelerado de incorporação de novas práticas e equipamentos médicos nos hospitais, exigindo constantes adaptações do edificio hospitalar. Ao arquiteto, portando cabe projetar uma edificação que possa suportar essas transformaçōes, sem abandonar o partido originalmente adotado e, principalmente, sem grandes transtornos para os usuários. ${ }^{67}$

Tal característica obtém-se com a utilização de instalações racionais, divisórias móveis, etc. A flexibilidade é fundamental pois, seus elementos arquitetônicos devem possibilitar adaptações para que a qualidade seja uma meta permanente. Além disso, pode-se dizer que um moderno hospital vive em obras desde a sua inauguração, consagrando-se como um voraz consumidor de áreas. A reserva, portanto, de grandes espaços para ampliação constitui-se praticamente como uma imposição.

\footnotetext{
${ }_{65}^{64}$ BRASIL (1995, p. 09) PINTO (1996, p. 42) ${ }^{67}$ TOLEDO (2007, p. 445)
} 
Como coloca KARMAN, mudanças num estabelecimento assistencial de saúde são inevitáveis:

Mudancas e progressos são constantes, contínuos e infindáveis; novos equipamentos e instalações, de progressivo custo, precisão, tecnicidade e sofisticação demandam crescentes conhecimentos e cuidados, acompanhamento, dedicação, organização, disciplina e responsabilidade. ${ }^{68}$

O requisito de flexibilidade dos ambientes tem realmente a função de permitir a evolução das técnicas, dos equipamentos e da adaptação da construção a todas as novidades que vão surgindo, mas o que não pode deixar de ser salientado é que estas adequações constantes devem gerar, principalmente no caso dos estabelecimentos assistenciais de saúde, o menor incômodo possível, em função de seu principal usuário, o paciente. "Os problemas relacionados com as modificações de uma unidade hospitalar já construída, reduzir-se-ão enormemente se o projeto dessa unidade permitir adaptações às novas funções. (...) Para isso duas condições são primordiais: flexibilidade e durabilidade.... 69

Alguns estudos sistemáticos e muito sérios na Inglaterra questionam a questão da flexibilidade em hospitais, mas o fato é que no Brasil, tal requisito dever ser colocado de maneira que, se não existir pode colocar o funcionamento de muitos estabelecimentos em xeque, inclusive pela falta de recursos financeiros que obrigam a fazer adaptações nos prédios existentes ao invés de investir em novas construções, como colocam os estudos na Inglaterra.

Nos estudos práticos, verificar-se-á que esta questão é pertinente, conforme defende Lelé (João Filgueiras Lima) na citação de TOLEDO:

[.] quase tudo que havia projetado há 30 anos atrás, estaria hoje completamente obsoleto se, naquela época, tivesse adotado um partido fechado, que não tivesse as condiçỗes de flexibilidade necessárias para suportar a permanente evolução das práticas médicas que ali ocorreram desde 1970. ${ }^{70}$

\section{F - Preocupações com o conforto ambiental}

Para CORBELLA \& YANNAS (2003, apud ANA VIRGINIA CARVALHÃES DE FARIA, 2004, p. 155), uma pessoa está confortável quando observa ou sente um acontecimento ou fenômeno sem preocupaç̃o. incômodo, ou, quando está em um ambiente físico sentindo neutralidade com relação á ele. ${ }^{71}$

É exatamente esta sensação que deve ser buscada principalmente nos ambientes assistenciais de saúde: ela está envolvida na recuperação do paciente e é papel da arquitetura garantir essa condição. "Conforto ambiental, de acordo com KOENIGSBERGER et al. (1977 apud SAMPAIO, ANA VIRGINIA CARVALHÃES DE FARIA, 2004, p. 154), é a sensação de bem-estar completo, físico e mental, criada por um arquiteto no ato de projetar." Como salientam também FROTA e SCHIFFER:

68 KARMAN (1994, p. 14)

${ }^{69}$ PINTO (1996, p. 42)

71 SAMPAIO (2004, P. 155)
À arquitetura cabe, tanto amenizar as sensações de desconforto impostas por climas muitos rígidos, tais como os de excessivos calor frio ou ventos. como também propiciar ambientes que sejam, no mínimo, tão confortáveis como os espacos ao ar livre em climas amenos ${ }^{72}$

De acordo com SAMPAIO (2004) considera-se 'qualidade' como sendo a sensação de conforto e bem-estar do usuário do ambiente construído, isto é, a sensação de ele sentir-se bem em um ambiente hospitalar, sendo um usurário ou sendo um paciente, um acompanhante, um médico, um visitante, um enfermeiro ou um funcionário.

FROTA e SCHIFFER ressaltam ainda que, quando a relação entre arquitetura e os requisitos de conforto ambiental encontram equacionamento eficiente, tal benefício ainda pode trazer economia na manutenção do edifício quando em funcionamento. Por exemplo, quando os diferenciais de temperatura interna e externa ao edifício proporcionam menor consumo de energia, também será demandado menor esforço dos equipamentos de refrigeração ou aquecimento para se equilibrar tais diferenciais:

A arquitetura, nas regiões de clima predominantemente quente, deve, segundo FROTA \& SHIFFER (1995 apud SAMPAIO, ANA VIRGINIA CARVALHÃES DE FARIA, 2004, p. 156) minimizar as diferenças entre temperaturas externas e internas do ar. Mesmo em locais com condições climáticas muito rígidas, propostas que valorizem o desempenho térmico natural podem ajudar a reduzir a potência dos equipamentos de refrigeração ou aquecimento, pois será menor a quantidade de calor retirada ou fornecida ao ambiente, beneficiando o edifício no consumo e na eficiência energética.

Importante ressaltar que, para se adquirir uma condição de conforto ambiental minimamente adequada, alguns recursos precisam ser considerados na produção do edifício para que juntos respondam às demandas pelo conforto ambiental. Embora sejam vários, serão comentados, a seguir, apenas os aspectos da ventilação natural e artificial, de iluminação natural e artificial, do tratamento acústico e referentes à utilização de cores, reunidos no que se denomina "conforto térmico" e "conforto visual",

Há muitos outros fatores que influenciam esta questão, tais como a utilização de vegetacão da água, a relação entre interior e exterior do edifício, mas tais condições serão consideradas mais adiante, separadamente.

\section{F1 - Conforto Térmico:}

Segundo SAMPAIO, conforto térmico é o conforto ambiental que abrange as sensações de bem-estar em relação à temperatura, umidade relativa e movimento do ar, radiaccão solar e radiação infravermelha, emitida pelo entorno. Ou ainda, segundo a ASHRAE (American Society 
of Healting, Refrigerating, Air-conditioning Engenieers), conforto térmico é definido como: Um estado de Espírito que reflete a satisfação com o meio ambiente térmico que envolve a pessoa. ${ }^{74}$

Sabe-se que atualmente é fácil garantir a sensação de conforto térmico através do uso de materiais de controle, como peles de vidro refletivas para regular a entrada dos raios solares no ambiente, equipamentos de ar condicionado para controlar a temperatura interna, entre outros meios. Sabe-se que tanto a ventilação artificial quanto o controle de temperatura artificial são ferramentas que estão disponíveis para serem utilizadas. 0 que acontece, em geral, é uma utilização equivocada dessa tecnologia.

Enquanto estes aparatos tecnológicos artificiais deveriam trabalhar em harmonia com os recursos técnicos naturais para suprir uma necessidade mais específica, atualmente elessão muito utilizados como solução de problemas do conforto que a arquitetura não resolveu eficientemente. Isto é e abusando um pouco da analogia -, a utilização de equipamentos mecânicos e eletrônicos para assegurar algum conforto térmico tem sido mais curativa que preditiva. Mais, a arquitetura muitas vezes deixa de lado a preocupação com o conforto térmico no interior do edifício exatamente por saber que há mecanismos técnicos para atender a tais demandas. Isso é um erro conceitual que gera problemas sérios, principalmente nos estabelecimentos assistenciais de saúde, como, por exemplo, um alto custo de energia para manter aquecedores ou refrigeradores ligados, problemas com a proliferação de agentes de infecção hospitalar pelo sistema de ar condicionado - que, inclusive tem um alto custo de manutenção em função da sua necessária assepsia - etc. E, assim, mais e mais problemas vão surgindo.

No caso da ventilação forçada ou artificial, ela tem papel muito mais eficiente quanto utilizada em conjunto com a natural. Em situacões de extrema necessidade, ela pode ajudar no equilíbrio da temperatura, em situações onde, por exemplo, são necessários controles de temperatura e umidade, como centro cirúrgicos, UTIs etc. Sua utilização é sempre recomendável, mas tudo sempre dentro de certo bom senso, parametrizado pelo conhecimento que o arquiteto projetista deve adquirir para enfrentar a concepção de um espaço deste gênero.

Ventilação natural: a sua utilização é bem vinda nos casos dos ambientes hospitalares, sempre lembrando que ela pode influenciar muito na recuperação do paciente. Pessoas gostam de ar fresco e luz natural, mesmo quando a reação emocional não é tão importante (ROSENFIELD, p. 284). "A ventilação natural proporciona conforto através da renovação do ar do ambiente, sendo de grande importância para a higiene em geral e para o conforto térmico de verão em regiões de clima temperado e de clima quente e úmido."75

\section{F2 - Conforto Visual}

Segundo SAMPAIO, a definição de conforto visual, lúmico ou luminoso, é: conforto ambienta que se refere ao bem-estar com relação a ver bem, a ter uma quantidade de luz satisfatória que possibilite a realização de uma tarefa visual confortavelmente.

Obviamente, quando se fala em conforto luminoso, fala-se não somente de iluminação natura e artificial, mas também de cores, que são, na verdade, resultados da incidência da luz nos diversos elementos, como paredes, forro, móveis etc.

Para ser mais bem entendida a questão da iluminação, é fundamental entender sua evolução para que certas colocações e os seus porquês fiquem claros pois a iluminação, tanto natural quanto artificial, exerce fundamental influência na qualidade dos ambientes, desde o início da história dos ambientes assistenciais de saúde.

Quando se fala em iluminação natural, observa-se que nem sempre os estabelecimentos assistenciais de saúde tiveram a preocupação de hoje com tais recursos. Demorou-se concluir que a luz natural, dentro do ambiente, trazia benefícios.

Na Idade Média, por exemplo, as enfermarias eram controladas pela igreja e sua concepção seguia a das catedrais góticas: pequenas aberturas, que pouco iluminavam o ambiente. Mais ainda: impunham, pelo jogo claro/escuro, um ar dramático ao ambiente, o que, certamente, era prejudicial aos pacientes, não só psicologicamente, como também pela falta de salubridade. 0 conceito dos edifícios de saúde era bem diferente do atual: as enfermarias eram consideradas depósitos de doentes, não tinham o objetivo de curar o paciente e sim de tratá-lo até a morte. Por isso, eram conhecidas como "salle de mourir", pois dificilmente alguém retornava desses lugares. Analisando-se, ainda hoje há resquícios dessa concepção, pois as pessoas mais velhas têm medo de frequentar hospitais, tendo em mente, inconscientemente, que vão para o hospital para morrer.

Tal concepção começou a mudar quando o controle de tais edifícios passou da igreja para o mundo secular. Aparecem os corredores como forma de circulação, dividindo os ambientes e promovendo a separação dos pacientes por sexo e patologia, surgindo também alguma preocupação com o conforto deles - o que pode ser percebido pela utilização de dutos, lareiras e iluminação com queima de óleos. Ainda que não seja a situação ideal - pelos conceitos atuais -, percebe-se uma grande mudança na sua concepção.

75 FROTA S SCHIFFERR (2003, p. 124) 
No século XIX, já se vê, em alguns hospitais, a preocupação com as janelas para iluminar e ventilar internamente os ambientes. "A importância da ventilação e da insolação se propagou,

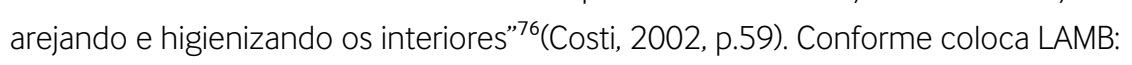

LAMB (2000 apud SAMPAIO, ANA VIRGINIACARVALHÃES DE FARIA, p. 186) comenta que as janelas são aconselháveis nas salas de recuperação, não só pela luz natural funcionar como um estímulo aos pacientes, mas principalmente, comenta o autor, para o conforto dos funcionários e para evitar o estresse pela permanência continuada em um ambiente fechado. ${ }^{77}$

Pasteur iniciou uma série de pesquisas que resultaram na modificação das concepções sanitárias em relação ao ar interior. A luz natural continuava tendo sua importância, principalmente por dar ao paciente a noção de tempo, para se orientar e proporcionar a sensação de liberdade. pelo contato com o meio externo. Mas a luz e o calor do sol, que controlavam a umidade e a proliferação de microorganismos, nem sempre eram desejados.

Na década de 50 do século XX, apareceram os estudos de elementos de controle da luz solar, objetivando iluminar as áreas mais profundas e reduzir o excesso de luz próximo à janela, garantindo qualidade de iluminação para os pacientes em ambos os locais. Segundo SAMPAIO:

Várias doenças e desajustes psicológicos são relacionados com a ausência de luz. Arquitetos, projetando adequadamente janelas para a iluminação de ambientes, podem contribuir com o aumento da produtividade e a saúde psicológica de seus ocupantes. $^{78}$

Portanto, atualmente, projetar utilizando a iluminação natural, requer conhecimento e técnica, conforme se pode observar.

É importante também prever uma distribuição homogênea de luz no ambiente preocupando-se, na elaboração do projeto, com a localização, a orientação , o tipo, o tamanho e a forma geometrica das aberturas, o tipo e a cor dos vidros que serão utilizados, as cores que serão usadas nos caixilhos, nas superficieies internas como teto, paredes e piso nas superfícies externas, como muros, piso e construçōes adjacentes, lembrando sempre que as cores claras refletem mais e difundem melhor a luz que as cores escuras, além de absorverem mais, diminuindo assim a quantidade de calor que será emitido por essas superficies escuras para o meio-ambiente. Não devemos esquecer ainda as características formais do local a ser iluminado como a relacão comprimento e largura e altura do pé-dire to que intermais do local ser ilu quantidade de luz disponive. Para projetar leva celeste e entorno. ${ }^{79}$

As principais vantagens da iluminação natural sobre a artificial são: quantidade de luz; comunicação interior/exterior; conservação de energia; benefício físico e psicológico; desejo de ter luz natural e sol em um ambiente construído. ${ }^{80}$

${ }_{77}^{76} \operatorname{COSTI}(2002$, p. 59)
Com a revolução industrial, uma grande mudança ocorreu nos edifícios em geral, com a utilização da lâmpada elétrica.

Dentre as grandes vantagens que ela trouxe, podemos destacar:

- Eliminação de poluição no ambiente: a lâmpada elétrica deixa de poluir o ambiente, pois se elimina a geração de luz a partir de queima de óleos;

- Complementação da iluminação natural: permite uma melhor utilização dos espaços nos quais a luz natural não chega com a devida intensidade;

- Possibilidade de tarefas ininterruptas: com a utilização da lâmpada elétrica, tarefas antes feitas somente durante o dia, começaram a poder ser realizadas também durante a noite, como, por exemplo, cirurgias e atendimentos de emergência, reduzindo a morbidade e aumentando obviamente a qualidade do atendimento ao paciente.

Tais conceitos vêm ao encontro ao comentário de VIANNA \& GONÇALVES:

É importante lembrar que a iluminação artificial deve complementar a iluminação natural, sendo utilizada nos casos em que ela for realmente necessária, lembrando-se que juntamente com ela existe um interior do ambiente, interferindo no conforto térmico também. ${ }^{81}$

Além da lâmpada elétrica, os equipamentos elétricos necessários e úteis aos procedimentos médicos também se proliferaram, como não poderia deixar de ser. Em meados do século XX, os edifícios de saúde já se tornavam grandes consumidores de energia elétrica.

A descoberta da lâmpada fluorescente veio trazer alguns benefícios à iluminação artificial

- Permite o mesmo nível de iluminação com um consumo menor de energia elétrica.

- É uma iluminação mais fria.

- Em função de seu formato tubular, permite uma melhor distribuição da luz.

- lluminação mais eficiente.

Com o avanço das possibilidades de iluminação artificial, alguns preceitos necessariamente passaram a ter maior importância. Por exemplo, uma iluminação eficiente transmite ao usuário uma sensação de segurança: embora o risco, em termos hospitalares, seja formulado em função

${ }^{81}$ VIANNA \& GONÇALVES (2001 apud SAMPAIO, p. 162) 
do procedimento médico, esta sensação tem muita influência no estado emocional do utente.

Outro aspecto importante é o fato de que a iluminação influencia no diagnóstico do paciente. A utilização de cada tipo de lâmpada deve ser escolhida com muito critério em função do procedimento ao qual estará ligada, já que as lâmpadas podem modificar a coloração de pele e induzir a um diagnóstico errado.

Ainda mais: a iluminação artificial tem que ter como objetivo a busca das características da iluminação natural, pois ela influenciará na reflexão e percepção das cores, influindo no ambiente.

É importante, num hospital, poder ser fácil a leitura de um termômetro, bem como serem facilmente notadas quaisquer anormalidades na cor da pele, dos lábios, das unhas... todos os outros sintomas que os procedimentos clínicos mais elementares ensinam e praticam. ${ }^{82}$

De qualquer forma, não importa quão boa a luz artificial seja (e com equipamentos modernos ela pode ser excelente): ela não pode substituir a iluminação natural, a menos que toda nossa concepção de vida e conforto mude. ${ }^{83}$

Analisando estes aspectos da iluminação, tanto a natural quanto a artificial, nos edifícios assistenciais de saúde, pode-se notar o grau de complexidade existente - o que nos faz salientar alguns desafios constantes na elaboração dos projetos, tais como a preocupação com o consumo energético, a valorização dos ambientes e o conforto ambiental.

Mas não são só estes aspectos que devem ser considerados: luz e cor são elementos fundamentais na recuperação e no bem-estar do paciente e estão diretamente ligados. Para se estabelecer o sistema de iluminação e a utilização de cores, deve-se saber o perfil do usuário/ paciente e, principalmente sua patologia, elementos importantes na elaboração de todo o complexo de um edifício de saúde. Cada ambiente tem que ser estudado de acordo com a enfermidade do paciente, a sua idade etc. (GOETHE, 1993, p.139). LIDA ainda coloca:

...para LIDA (2002 apud SAMPAIO, ANA VIRGINIA CARVALHÃES DE FARIA, p. 163) é uma resposta subjetiva para um estímulo luminoso que penetre nos olhos. Quando a luz incide sobre um objeto, parte das ondas luminosas é refletida e parte é absonvida. A cor que enxergamos desse objeto é a que foi refletida por ele. após a incidência da luz e que penetrou nos olhos causando o estimulo e resposta a El por ele,

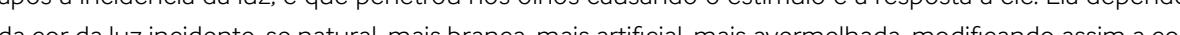
com que o objeto é visto ${ }^{84}$

Acredita-se que a cor tem a capacidade de modificar o ambiente e a orientação do paciente. Por isso, podemos dizer que não há cores belas ou feias e sim a escolha adequada ou não a ser utilizada em cada situação.

${ }_{83}^{82}$ ROSENFIELD (1950, p.285)

${ }^{83}$ Ibidem, p. 284 LDA (2002 apud SAMPAIO, p. 163)
Cores neutras, como o branco e o cinza, têm aparência monótona, além de induzirem à ansiedade tensão, medo e sofrimento; cores frias amenizam a sensação de calor; cores claras transmitem sensação de limpeza e amplitude e cores escuras transmitem sensação de sujeira e claustro.

Além da utilização da cor em si, uma possível combinação delas produz efeitos diferenciados: ambientes com uma só cor dão a sensação de monotonia, ambientes com muita variedade de cores confundem e desagradam.

Vale lembrar, também, que a cor é um estimulante psíquico, podendo afetar o humor, a sensibilidade, produzir emoções e reflexos sensoriais nos pacientes (COSTI, 2002. p.115.). Mais um motivo para uma detalhada análise quando da escolha dela para a enfermaria. "A experiência nos ensina que cores distintas proporcionam estados de ânimo específicos" ${ }^{\prime 25}$.

ALMEIDA defende o ponto de vista que a cor tem o poder de complementar a terapia: "[... além do efeito psicológico, a cor atua efetivamente como elemento de cura, quando o paciente passa longos períodos sob sua ação." "Na França e nos EUA, a medicina convencional utiliza a cor como complemento das terapias mais usuais."

É importante, também, a preocupação técnica de compatibilização das cores escolhidas com o tipo de iluminação (natural e artificial) da enfermaria e vice-versa. Por exemplo, a cor branca devido à alta refletância, induz à fadiga caso a intensidade da luz não possa ser controlada.

Há também alguns recursos simples, muito utilizadas, como a escolha de cores suaves em pisos e forros a fim de contribuírem para a refletância da luz. Nas superfícies verticais, podese, em função da utilização/objetivo da enfermaria, optar-se por um ambiente acromático, sem saturação, utilizando-se as cores branca, preta e cinza, por exemplo; ou optar-se por um ambiente monocromático em diferentes intensidades e variedades; ou, ainda, optar-se por um ambiente policromático com variedade e intensidade de cores

Enfim, não há uma regra para a escolha da cor ou sistema de cores nas enfermarias. A direção a ser seguida é a mesma para todo o conceito construtivo do estabelecimento: pertinência e adequação ao uso.

\section{G - Presença de verde}

Segundo Malkin (1992 apud MEDEIROS;LUCIANA DE, 2004, p.12), alguns fatores tem a função de propiciar o restabelecimento de pessoas hospitalizadas, entre os quais, podem ser citados, a possibilidade de comunicação com a equipe médica e de enfermagem, o controle de ruídos e a criação de espaços que permitam, por exemplo, a visualização da natureza. ${ }^{87}$

${ }^{85}$ (GOETHE, 1993, . . 140)
${ }_{\text {86 (ALMEIDA 1997) }}$ 
A utilização de vegetação - jardins, internos e externos, ou apenas simples cuidados paisagísticos - nos estabelecimentos assistenciais de saúde, tem benefícios tanto para o paciente, que tem melhor qualidade do ambiente enquanto internado, quanto para a equipe médica e funcionários, conforme comenta SAMPAIO:

Projetar jardins acessíveis nos edifícios hospitalares é benéfico para os administradores, pela redução de custos com medicamentos e tempo de internação, para os pacientes, pelo efeito relaxante, diminuição do nivel de ansiedade, estresse, aumento de independência e para a equipe, por melhorar o seu ambiente trazendo-lhe maior satisfação. 88

"A simples visualização das plantas pode reduzir o estresse" ${ }^{19}$. Lelé, que utiliza o verde em todos os hospitais da rede Sarah, ainda lembra que, além dos benefícios que a vegetação pode oferecer ao paciente, ela também ajuda a melhor resolver as questões de conforto térmico:

Os espaços verdes, nas áreas contíguas à edificação, são indispensáveis também para minimizar o ganho de calor nos ambientes internos. Superfícies como o concreto, em ambientes externos, aumentam o calor por irradiação, no entanto, a areas verdes ou espelhos d’água servem de amortecedores e propiciam um conforto térmico razoável no entorno da edificação."

Outro artifício muito interessante e bastante utilizado em conjunto com a utilização do verde do ajardinamento cuidadosamente planejado, é a utilização da água, pois ela, além de auxiliar nas questões de regulação do conforto térmico, também influencia na questão do conforto acústico, visual e olfativo, além de trazer para o ambiente uma sensação de aconchego, conforme comenta SAMPAIO:

..uso da vegetação e da água. As plantas, assim como a água, têm grande influência na questão do conforto térmico, visual, acústico e olfativo como também na sensação psicológica de aconchego, de contato com a natureza, que juntamente com a música, quadros e gravuras com motivos naturais, podem interferi positiva e beneficamente no bem-estar dos ocupantes de um ambiente, principalmente quando se tratar de um ambiente hospitalar e seu usuário for um ser fragilizado, que se encontra acamado, imóvel e sensível a todos os estímulos deste ambiente. ${ }^{91}$

A água também transmite a sensação de frescor, tranquilidade, paz e usada em movimento, pode ampliar os efeitos psicológicos positivos em usuários sob tensão ou para descontrair, relaxar os que exercem atividades que exijam excessiva concentraç̃ão.

\section{H - Relação interior $x$ exterior}

A questão da relação entre o interior e o exterior está bastante ligada à questão da presença do verde pois é através dela que se busca proporcionar um diálogo entre as áreas internas e externas do edifício, através das aberturas. Quando se fala nesta relação, não necessariamente

\section{${ }_{88}^{88}$ SAMPAIO (2004, p. 183)}

${ }_{90}^{89}$ bidem, p. 173

91 LIMA (2005 apud MONTERO, 2006, p. 153)

${ }_{92}$ SAMPAIO (2004, p. 173) deve-se entendê-la apenas como acesso de ligação física, mas também de ligação visual composição de claros e escuros, transparências e opacidades, cheios e vazios etc. Quando esta ligação é estabelecida e consegue-se, por exemplo, fazer com que a área externa seja uma continuidade da área interna, a relação está estabelecida de maneira muito eficiente.

Esta relação harmônica entre o exterior e o interior é importante não só para se ter acesso às áreas verdes, mas também para se viabilizar acesso à ventilação e iluminação natural, o que traz muito conforto ao usuário principalmente ao paciente. Por causa do fator psicológico - extremamente importante -, trabalhadores têm afirmado que embora gostem do conforto estabelecido por condições controladas, também gostam de vidro suficiente para ao menos verem como o tempo está. (ROSENFIELD, 1950, p.284). Já no caso dos pacientes, outro aspecto é garantido por esta relação: a sensação de segurança. Não a sensação de segurança usual. mas a sensação de segurança que é adquirida com a percepção de dia e noite. Um paciente moribundo está longe de mostrar as emocões, quer o sol brilhe ou não, mas até isto às vezes não é verdade. Um paciente muito doente às vezes prefere um nível mais baixo de luz; luz abundante pode ser facilmente controlada para o nível desejado, usando cortinas ou persianas. O paciente usual, contudo, particularmente os de longa estadia no hospital, que passam dias, semanas e até meses, anseiam ardentemente pelo prazer da luz natural e o da vista do céu. (ROSENFIELD, 1950, p. 285)

"... o doente internado fica desligado do 'mundo exterior', a sensação de abandono, medo do desconhecido, descontentamento e desgosto pode acompanhá-lo durante a sua estada no local|"93. CAPMAN faz algumas recomendações:

CAPMAN et al.(1986 apud SAMPAIO, ANA VIRGINIACARVALHÃES DE FARIA, p. 198) fazem recomendações com relação às áreas externas. Se possivel, todos os ambientes devem ter acessos a áreas sombreadas, com fontes de água, vegetação, local adequado e confortável para sentar, para que possam caminhar acompanhados de enfermeiros e acessível para cadeiras de rodas e macas. No caso de pacientes que não possam ir para fora as janelas devem permitir o contato com o exterior para que eles possam

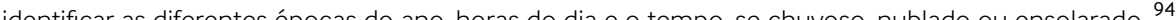

Além de tudo, a relação do paciente com o exterior, oferece a ele um relaxamento físico e psicológico, conforme comentam HOPKINSON \& KAEY:

De acordo com HOPKINSON \& KAY (1969 apud SAMPAIO, ANA VIRGINIACARVALHÃES DE FARIA, p. 186), uma janela possibilita descanso visual pois permite uma ligação direta com o mundo exterior, com as diferentes variacões que ocorrem no decorrer de um dia 0 homem tem necessidades de variac̃a mudança e as janelas favorecem um relaxamento físico e psicológico, pois permitem o

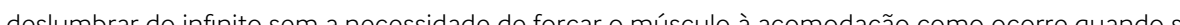
observa alguma coisa próxima.

${ }^{93}$ MEDEIROS (2004, p. 30 95 apud SAMPAIO, p. 198 SAMPAIO (2004, p. 187) 


\section{I - Humanização dos espaços}

Humanização da assistência hospitalar é um termo abrangente utilizado para definir um movimento em busca da valorização da pessoa que faz uso dos serviços de saúde, considerando o paciente e o profissional como parte essencial no processo, sendo o primeiro o principal foco da atenção. ${ }^{96}$

O termo humanização dos ambientes hospitalares tem sido muito veiculado, tanto pelos autores analisados, como ANELLI, GUERRA \& KON, COSTI, DALLAS, FIGUEIREDO, GERROLA. GODOI, GOLDENSTEIN, LEÃO, LIMA, MALKIN, MEDEIROS,PRUDENTE, REIS, TOLEDO entre outros, quanto pela área médica como um todo. Está claro, porém, que esta questão, embora seja importante para a recuperação do utente, como aborda o próprio Ministério da Saúde na Política Nacional de Humanização do SUS (humanizaSUS), nem sempre é abordada, em nível prático, em primeiro plano.

REIS, em sua Monografia "O Ambiente como Recurso Terapêutico nos serviços Públicos de Saúde", pela Faculdade de Terapia Ocupacional, descreve, através dos comentários a seguir - e de maneira bastante eficiente -, a situação do paciente que passa praticamente por um processo de despersonalização, a preocupação com sua acolhida no hospital e também a adequação entre ele e o ambiente:

Um dos fatores externos, já bastante estudado e que pode causar instabilidade no desenvolvimento humano é o ambiente hospitalar e ambulatorial, que rompem com a rotina familiar, relações sociais e atividades do dia-a-dia. Apesar de terem como finalidade a melhoria da saúde do enfermo, muitas vezes as intervenções são dolorosas, podendo até ser mutilantes, gerando transformações corporais e traumas psicológicos. As rotinas nestes serviços são impostas e o paciente, muitas vezes, passa a ser despersonalizado, passando de pessoa a um número.

Dentro dos hospitais existem diferentes ambientes nos quais os enfermos são divididos por diversas características como: gravidade da enfermidade, idade, tempo de hospitalização, entre outros. Os profissionais da saúde tem como função adequar estes ambientes o máximo possivel, para que 0 enfermo possa se sentir acolhido, ajudando na sua própria melhora ${ }^{98}$

Nos quartos hospitalares deve-se verificar a ventilação, a iluminação e se a posição do leito permite a deambulação do enfermo. Além disso deve-se levar em conta a opinião do paciente e da família se houver a possibilidade de mudanças nos locais dos mobiliários e objetos. ${ }^{99}$

Também é importante lembrar que a questão da humanização dos ambientes hospitalares não está unicamente vinculada à arquitetura. Na verdade a arquitetura pode agregar valores objetivos e subjetivos aos espaços projetados e aí sim. somarem-se estes aos demais elementos que tornam os ambientes hospitalares realmente humanos. A arquitetura é uma parcela a ser somada no todo pela busca na eficiência do tratamento humanizado para o paciente.

Capaz de despertar sentimentos, o ambiente ajuda no tratamento e adaptação do paciente devendo, portanto, ser adequado a cada usuário. Do mesmo modo, complementa COSTI:

...descobriu-se que o espaço das pessoas tinha relação com seu eu interior, que os efeitos da luz e da cor interferiam tanto na parte física quanto na parte emocional dos seres humanos e que a noção de tempo ficava alterada. ${ }^{100}$

Importante salientar que, com a evolução do aparato tecnológico hospitalar e do conhecimento sobre o comportamento emocional dos pacientes, cada vez mais forte se torna a preocupação com este requisito: [... a evolucão do hospital e sua nova imagem modificada pelas tecnologias e humanização dos espaços
gerou o aparecimento de edifíicios que primam pelo conforto do paciente.

Vale lembrar que este requisito não é como os outros, um requisito exclusivamente técnico e sendo assim, torna-se um desafio ao arquiteto projetista atendê-lo. Sabe-se que o expedito atendimento dos demais requisitos básicos mencionados anteriormente já torna este desafio muito mais fácil de se enfrentar, pois se o estabelecimento de atendimento à saúde for adequadamente implantado, o projeto for eficiente do ponto de vista funcional, as circulações e agrupamentos forem adequadamente racionalizados, se existir uma preocupação decisiva com a questão do conforto ambiental, com a presença do verde e a relação entre interior e exterior. uma grande parcela do requisito mais geral da humanização estará garantida: certamente os ambientes deverão ser mais agradáveis, tanto para os pacientes em recuperação, quanto para a equipe que deles trata.

A questão que precisa ser esclarecida é que, atualmente, na grande maioria dos estabelecimentos assistenciais de saúde, a questão da humanização dos espaços representa um diferencial um algo a mais, geralmente associado à valoração de um produto disposto como mercadoria, quando, na verdade, deveria ser tratada, consensualmente, como uma questão essencial, principalmente pelo fato de qualidade, nos termos propostos e a partir dos requisitos discutidos anteriormente, não representar, necessariamente, custos adicionais ou excessivos quando da implantação e construção da edificação.
96 MEEEIROS (2004, p. 12)
97 REEIS (2000, p.14)
98 Ibidem, p.15

${ }_{99}^{98}$ Ibidem, p. 15 


\subsubsection{Críticas}

Em função da revisão bibliográfica assistemática aqui apresentada - além da condição experimentada como usuário comum -, seria possível esboçar diversas críticas aos pressupostos atualmente utilizados para se pensar, especificamente, a arquitetura nos estabelecimentos assistenciais de saúde. Duas delas, contudo, são mais relevantes quando relacionadas ao trabalho de pesquisa em desenvolvimento.

A primeira crítica relaciona-se à interpretação do conceito de humanização que ocorre na prática. Pode-se ver claramente, principalmente nos hospitais particulares, uma valorização do luxo, dos serviços de hotelaria, apresentados como 'humanização' dos espaços. Obviamente, todo ser humano gosta de conforto e luxo, mas não é esse tipo de 'humanização' que traz qualidade ao ambiente. Ele pode sim ser utilizado, não se pode ser contra esse tipo de artifício. O que precisa ficar claro é que o luxo ou os serviços de hotelaria nada mais são que elementos opcionais de composição de atendimento ao usuário, para além do estrito atendimento à saúde e que será comprado por aquele indivíduo que pode e quer pagar por eles. Mas eles não devem ser considerados como fator que torna o ambiente mais ou menos humano.

O que se vê hoje é que "... enquanto hospitais privados têm aparência física de sua estrutura considerada como humanizada, hospitais públicos enfatizam a humanização do atendimento, num contraste que reforça as contradições do sistema de saúde do país."102

Atualmente, o que se nota - principalmente nos estabelecimentos assistenciais de saúde particulares - é uma valorização da 'humanização' dos ambientes, configurada, na verdade, pela composição do produto que se coloca à venda como serviços de hotelaria ou mesmo de luxo. 0 que vemos é, visivelmente, uma estratégia de mercado e de marketing, preconizando a humanização e o atendimento diferenciado apenas como um diferencial de produto. Como observa Godoy:

O modelo de hotel (..), segundo Miller e Swensson (1995 apud MEDEIROS; LUCIANA DE, 2004, p. 49) fol uma forma de proporcionar uma estada confortavel para pacientes e familiares durante a internação dos primeiros, além de possibilitar uma vantagem a mais para 'atrair' clientes. ${ }^{103}$

... hotelaria hospitalar e a introdução de técnica, procedimento e serviços de hotelaria em hospitais com o consequente benefício social, físico, psicológico e emocional para pacientes familiares e funcionários. ${ }^{104}$

Não há problema algum em se oferecer luxo para quem o quer e por ele pode pagar. No entanto, o grande problema é confundi-lo e amalgamá-lo como e enquanto atendimento essencial - o que ocorre quando ele é confundido com a idéia de humanização: ...existe uma tendência em comparar a estrutura de determinados hospitais à de hotéis, atribuindo-lhes a qualidade de 'humanizado' devido à variedade das opç̃os de seniço de conforto oferecido ao paciente. 105

Como se viu, humanização é o conceito que garante ao paciente um atendimento mais humano. mais próximo e que depende de uma série de fatores, dentre eles o ambiente confortável. Aparelhos eletrônicos como TVs de última geração, janelas controladas por controle remoto camas com ajustes automáticos, jogos de cama diferenciados, tratamento especial etc. pode até tornar o ambiente mais agradável e tolerável para quem pode pagar por isso. Mas, e para a imensa maioria da população que depende do sistema público de saúde? Se a humanização assume a condição de "produto diferencial" - e valorado como tal -, então não é possível um atendimento humanizado para esta população?

Claro que é, se o conceito de humanização for entendido corretamente. Um ambiente pode sim ser humanizado sem luxo algum. Os aspectos necessários para torná-lo humanizado são básicos e independem do luxo e da hotelaria e consistem no conforto ambiental, no atendimento adequado e bem informado, na boa relação do ambiente interno com o meio externo, na presença de verde e em outros já comentados e discutidos.

A segunda crítica que se pode ressaltar é relativa à legislação que regula os projetos, obras, utilização e procedimentos dos ambientes assistenciais de saúde. O que se vê ao analisar estas normas ou a legislação específica, é que ela é bastante limitada e bastante focada em questões técnicas, muito mais voltadas para procedimentos, dimensionamentos dos ambientes e para materiais aplicados e muito pouco preocupada com a questão conceitual que dá suporte à concepção dos projetos e obras, que é o que garante $\mathrm{o}$ atendimento aos requisitos básicos apresentados. Nitidamente, atribui-se apenas ao bom senso do projetista, o compromisso de elaborar um bom e eficiente projeto. Ou seja, seguindo-se todas as normas atualmente vigentes, pode-se tanto elaborar um excelente, quanto um péssimo projeto de estabelecimento. Ambos atenderão a todas as normas. Serem, afinal, eficientes é outra questão.

Também não se pode deixar de colocar que cada estabelecimento tem suas particularidades e é papel do arquiteto adequá-las em cada projeto:

É necessário também estar ciente de que, mesmo existindo normas projetuais, as diferenças programáticas e de dimensionamento muitas vezes impõem solucões diferenciadas que independentemente da maior ou menor experiência do arquiteto, só poderão ser criadas por meio do trabalho de equipe. ${ }^{106}$

O que definitivamente não existe é uma norma reguladora para os critérios que podem ser 
chamados de "requisitos que influenciam na recuperacão do paciente". O que acontece é uma solução muitas vezes desorientada, que visa sim melhorar a qualidade do ambiente e consequentemente influenciar na recuperação do paciente, porém sem critério algum, conforme vemos na citação de REIS:

Nos servicos ambulatoriais, além do aparato tecnológico disponivel para a atuaç̃o profissional, no setor público, consideram-se regras da ABNT para a construção de serviços de saúde como espaço, número de sanitários, entrada e saída e também regras de Vigilância Sanitária como salas com azulejos, materiais de fácil limpeza, cores neutras, entre outros. Não há estudos apontando fatores como cores, odores, texturas, disposição de mobiliário e objetos que demonstrem sua importância. Deste modo, o que ocorre é geralmente uma certa padronização destes elementos no serviço público. Os elementos próprios de cada serviço acabam ficando por conta dos profissionais que lá trabalham. ${ }^{107}$

Em função das etapas subsequentes, retornar-se-á a estas críticas com elementos novos que poderão trazer pontos de vista diferentes de forma a contribuir para a discussão dessa temática.

\subsection{Relação Arquitetura X Humanização}

Um dos objetivos principais desta pesquisa é analisar o conceito de humanização hospitalar entendê-lo em seu aspecto multidisciplinar e compreender o papel da arquitetura na composição interativa do complexo profissional articulado em torno da humanização dos espaços dedicados ao tratamento da saúde.

Este entendimento vai se tornando mais claro, conforme a revisão bibliográfica vai sendo construída. Fica evidente que a arquitetura é somente um elemento na questão da humanização do atendimento como um todo. Embora somente um elemento, mas não menos importante que os demais, já que "...espaço físico e atendimento são essenciais ao processo de humanização"108 Conforme MEDEIROS ainda nos mostra:

Nessas discussões, entretanto, não costuma haver referência à arquitetura como fator relevante para a humanização hospitalar, embora já se saiba que a estrutura física do edifício pode auxiliar no amenizar o impacto causado pela rotina hospitalar sobre os pacientes. ${ }^{109}$

Humanização da assistência hospitalar é um termo abrangente utilizado para definir um movimento em busca da valorização da pessoa que faz uso dos serviços de saúde, considerando o paciente e o profissional como parte essencial no processo, sendo o primeiro o principal foco da atenção. ${ }^{10}$
Como já comentado, a arquitetura dos estabelecimentos assistenciais de saúde é a arquitetura voltada para o ser humano talvez em seu estado de maior fragilidade. Entendendo-se desta maneira a arquitetura, fica clara a sua importância com relação ao bem-estar ou mesmo à recuperação do paciente. "...WINNICOTT revela o ambiente como fator fundamental para o equilíbrio mental do indivíduo. 0 ambiente, quando adequado, torna-se facilitador do processo de maturação do lactente..."111. TOLEDO ainda salienta:

podemos considerar que a definição, os objetivos e as propostas de humanização ainda se encontran em processo de construção. Sendo assim com o objetivo de participar dessa construção, lembramos princípios que regem uma boa arquitetura

Acreditamos, portando, que a humanizaç̃ão do edificio hospitalar resulte de um processo projetual que não se limita à beleza do traço, ao respeito à funcionalidade ou ao domínio dos aspectos construtivos, e alia a esses aspectos a criação de espaços que, além de favorecer a recuperação da saúde e garantir o bem-estar físico e psicológico aos usuários do edificio hospitalar, sejam eles pacientes acompanhantes ou funcionários, possa estimular a incorporação de novos procedimentos às práticas médicas. ${ }^{112}$

Há, também, quem vá mais além e defenda que o ambiente de atendimento de saúde precise ficar o mais parecido possível com o ambiente do dia-a-dia do paciente:

JORGE acredita que o ambiente terapêutico em um gabinete fisioterapêutico ou numa oficina terapêutica ocupacional deve ser composto por ambientes amplos, fartamente iluminados, podendo ou não ter barulho, fortes odores de tinta, parafina, vernizes, óleos etc. Por mais que perca a fantasia da relação terapêutica em um ambiente acolhedor, cálido, semi-escurecido, sugerindo discrição e calma, isto não significa que nestes ambientes não se consiga níveis profundos de relaxamento, confidências. encontros, até porque os ambientes urbanos e domésticos da maioria dos seres humanos são conturbados, barulhentos e possuem uma grande diversidade de odores, entre outros aspectos. ${ }^{113}$

SAMPAIO ressalta que a arquitetura tem a obrigação de ser voltada para o utente, para o ser humano:

A preocupação com os pacientes deve existir em todo o projeto, desde a concepcão, como um todo. até nos detalhes do seu interior. Cores, texturas, aberturas para visualizacão do exterior e entrada de auxiliam na recuperação do paciente. ${ }^{114}$

Também para os administradores esse enfoque tem se mostrado compensador. Analisando-se doze estabelecimentos filiados ao Planetree constatou-se que houve uma maior satisfação por parte dos pacientes e a sua recomendação para amigos e familiares. Foi posśvel relacionar também. a esses ambientes um menor número de erros médicos e diminuição da taxa de infeção Na major pate dos 
Maior prova de que este ponto de vista é acertado pode ser vista nos depoimentos dos pacientes do Maggie's, no documentário de Alan de Boton - Arquitetura da Felicidade - transcritos a seguir:

A primeira vez que eu entrei aqui eu parei e... Havia paz e tranquilidade neste lugar que realmente me ajudou. E, ao subir as escadas para olhar o rio pela janela senti que a tranquilidade do lugar me ajudou. (paciente diagnosticada com câncer em entrevista para Alan de Botton)

Aqui, você pode entrar e sair e é esteticamente agradável para mim. É bonito, é relaxante. Se você quiser ir a algum lugar, acho que ajuda se o local for agradável. (paciente em entrevista para Alan de Botton)

Sempre me sentia muito mais calma quando vinha aqui. Não sei se era por causa da luz ou da vista. Ou se muito natural. Eu sentia que podia me desligar. (paciente em entrevista para Alan de Botton)

Creio que as estruturas interna e externa, com as formas arredondadas da parede, daquela mesa, daquela escada Há poucas arestas e ângulos retos isso deixa o lugar mais envolvente. Sempre penso nele como aloo bem redondo onde posso entrar e. (paciente em entrevista para Alan de Botton)

Aqui, sinto-me livre, alerta, confiante, com a mente mais clara. Meus reflexos melhoram, sinto-me intelectualmente melhor porque há algo no lugar que faz com que eu me conheça melhor. Sinto-me confiante ao pensar nessas coisas. É um espaço maravilhoso que nos dá uma espécie de liberdade. (paciente em entrevista para Alan de Botton)

A Arquitetura certamente está entre os mais importantes elementos que compõem o conceito de humanização hospitalar. Ela tem o poder de tornar os espaços mais humanos e, sendo os espaços mais humanos, estes influenciam tanto a equipe de tratamento quanto os pacientes de maneira benéfica, aumentando assim o potencial ambiental de cura ou recuperação destes pacientes. Uma arquitetura de qualidade facilita o estabelecimento da organicidade dos demais elementos que influenciam na recuperação do paciente e, desta maneira, assume uma importância central em todo o processo de humanização - o que a torna indispensável. Ela tem um caráter único que não pode ser desconsiderado: a arquitetura pode ser entendida como uma humanização permanente e segura. Dentro de todo o processo, a arquitetura é o elemento mais estático e duradouro. A partir dela todos os demais elementos poderão se desenvolver melhor.

Um bom projeto de estabelecimento assistencial de saúde é aquele que olha o edifício pela perspectiva do paciente. Este fator é tão importante que é o fundamento para que, em qualquer lugar do mundo, com qualquer técnica construtiva, com qualquer recurso financeiro, torne-se possivel conceber a idéia de humanização destes ambientes como uma idéia universal. Desta maneira, o pressuposto de se apreender esta arquitetura sob o "olhar do paciente", pode ser entendido como sendo um preceito também universal.

Fica claro, então, que a arquitetura é instrumento e método importante neste processo, porque a arquitetura, se compreendida em sua essência, é, em si, atividade que produz efeitos universais. Se os conceitos básicos que dão substrato ao projeto forem plenamente atendidos, a tão buscada humanização é possível inclusive sem luxo algum. 


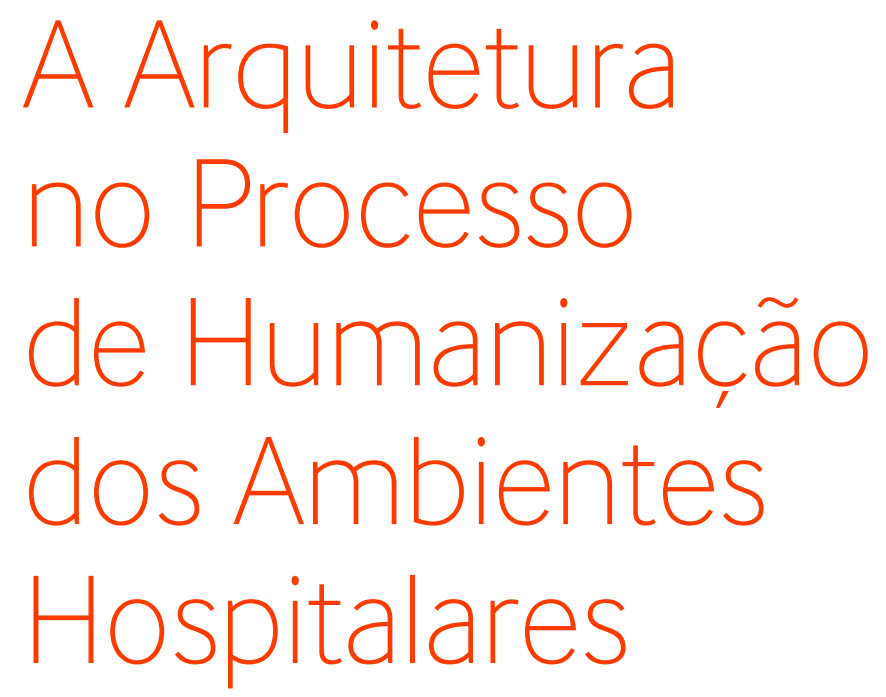

Ricardo José Alexandre Simon Ciaco

Orientador: João Marcos de Almeida Lopes

Dissertação apresentada ao Programa de Pós-Graduação em Arquitetura e Urbanismo da EESC / USP como requisito parcial no programa de MESTRADO na área de ARQUITETURA, URBANISMO E TECNOLOGIA.

São Carlos 2010 


Ciaco, Ricardo José Alexandre Simon
A arquitetura no processo de humanização dos ambientes
hospitalares / Ricardo José Alexandre Simon Ciaco i
orientador João Marcos de Almeida Lopes. -- São Carlos,
2010.
Dissertação (Mestrado-Programa de Pós-Graduação em
Arquitetura e Urbanismo. Area de concentração em
Arquitetura, Urbanismo e Tecnologia) -- Escola de
Engenharia de São Carlos da Universidade de são Paulo,
2010.
1. Edifícios hospitalares. 2. Humanização. 3. Projetos
hospitalares. A. João Felgueiras Lima. 5. Lelé.
6. Utente. 7. Conforto ambiental. I. Título.


Folha de Julgamento

Candidato(a): Arquiteto e Urbanista RICARDO JOSÉ SIMON CIACO.

Dissertação defendida e julgada em 24/03/2010 perante a Comissão Julgadora:

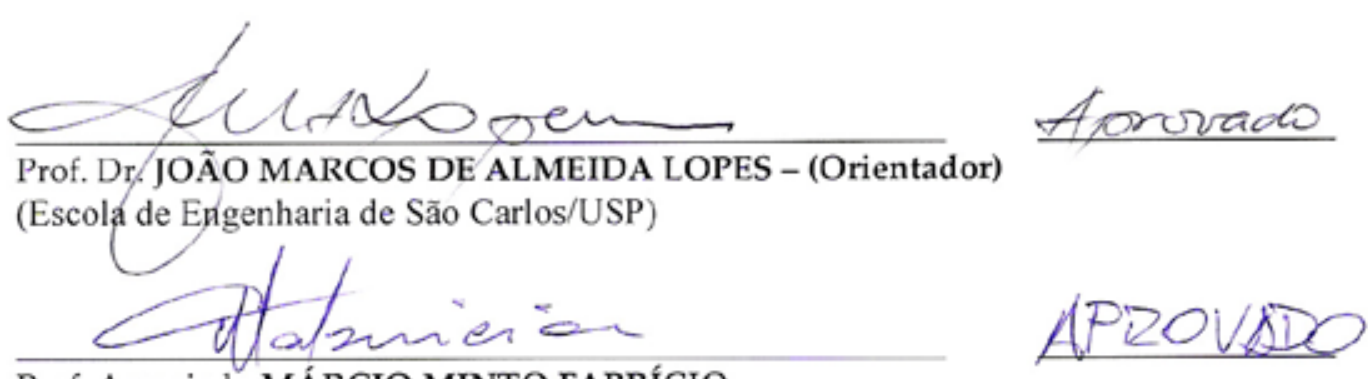

Prof. Associado MÁRCIO MINTO FABRíCIO

(Escola de Engenharia de São Carlos/USP)

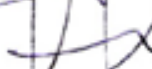

Prof. Dr. FABFO OLIVEIRA BITTENCOURT FILHO

$\triangle P R \triangle V A D O$

(Universidade Estácio de Sá/UNESA)

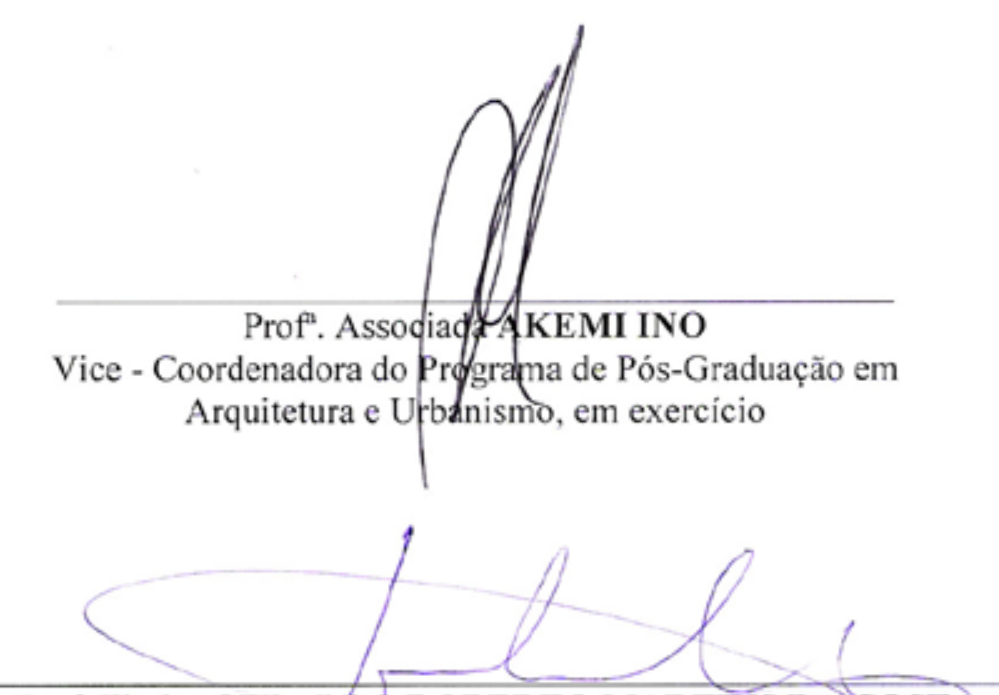

Prof. Titular GERALDO ROBERTO MARTINS DA COSTA Presidente da Comissão da Pós-Graduação da EESC 
Este trabalho é dedicado

à Daniela e ao Teo. 


\section{Agradecimentos}

Ao meu orientador, Prof. Dr. João Marcos Almeida Lopes que comigo compartilhou não somente o desenvolvimento desta dissertação como também a experiência de ter um novo membro na família;

Aos meus amigos e à família, principalmente aos meus pais, grandes incentivadores, e aos meus irmãos, que ofereceram em todos os aspectos muito apoio no período de estudos.

Um agradecimento especial à minha esposa Daniela que juntamente com meu filho Teo souberam entender minha ausência nesse período de dedicação ao mestrado:

Aos meus colegas de trabalho Ronaldo e Júnior, que no escritório cuidaram perfeitamente de tudo em minha ausência. Também à futura arquiteta Maria Paula que muito me ajudou.

Aos funcionários das instituiç̧ões visitadas, em especial ao Ivo Stigger da Santa Casa de Porto Alegre pela sua dedicação naquilo que Ihe foi possível, quando da minha visita à instituição.

Aos professores presentes nas bancas de qualificação defesa através de suas colocações e orientações muito contribuiram para o resultado final do trabalho.

Ao meu irmão João que, além de grande incentivador e motivador foi, para mim, um exemplo a ser seguido. Passou-me o gosto pelo trabalho acadêmico. 


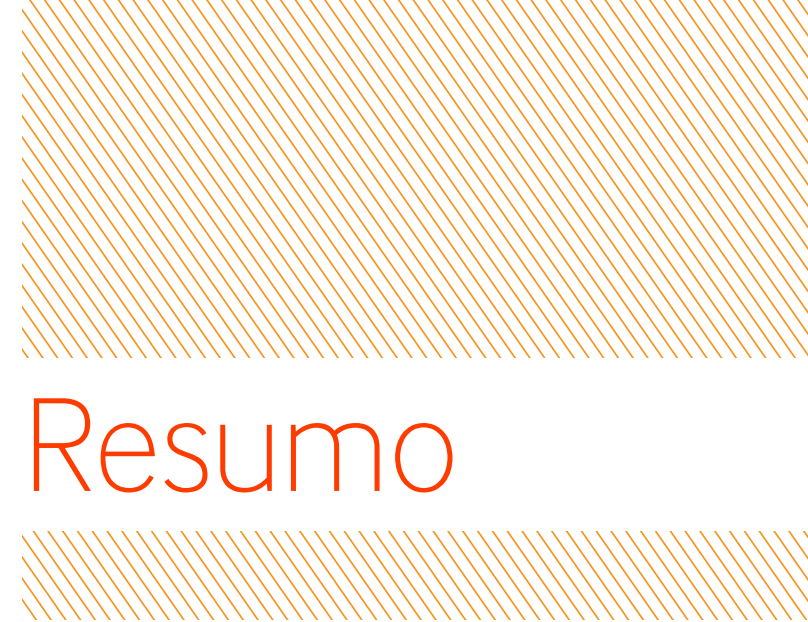

CIACO, R. J. A.S. (2010). Arquitetura no Processo de Humanização dos Ambientes Hospitalares. Dissertação (Mestrado) - Escola de Engenharia de São Carlos, Universidade de São Paulo, São Carlos, 2010.

A questão da humanização hospitalar parece ser temática bastante recorrente hoje, nas ciências da saúde, bem como na arquitetura. Este estudo visa compreender, através de um olhar voltado para a arquitetura, a estruturação e as práticas dos processos de humanização nos ambientes hospitalares. Para tanto, realizam-se incursões teóricas para melhor precisar o conceito de humanização em uma abordagem arquitetônica, tanto na perspectiva do utente, quanto na do trabalhador da saúde, bem como se realiza uma revisão da legislação que trata do assunto, visando uma melhor compreensão do papel do Sistema Único de Saúde no processo de humanização hospitalar. Ainda a partir de uma abordagem teórica, procura-se estabelecer parâmetros que possibilitem avaliar se estabelecimentos assistenciais de saúde podem ou não ser considerados humanizados, tentando-se elencar os requisitos básicos para se desenvolver uma arquitetura eficiente quanto à humanização desse ambientes. $A$ partir dos referenciais teóricos da humanização hospitalar nas suas relaç̃oes com a arquitetura, partese para uma análise de campo que permita, a partir das práticas em curso nos hospitais, verificar se há efetivamente uma preocupação de desenvolvimento e implantação de uma arquitetura voltada para a questão da humanização, bem como se os requisitos arquitetônicos apontados teoricamente dão conta e são suficientes para se pensar em uma arquitetura com tal propósito.

Nossa hipótese é a de que como nos hospitais públicos há menor disponibilidade de recursos, a preocupação com a humanização volta-se exclusivamente para os princípios essenciais e básicos de uma arquitetura preocupada com questão, sendo esses princípios arquitetônicos por si sós já suficientes para garantir um nível adequado de humanização no ambiente hospitalar. Desta maneira, o corpus de análise volta-se para o sistema público de saúde, elencando-se quatro estabelecimentos assistenciais de saúde que atendem preferencialmente usuários do SUS, em diferentes portes e complexidades operacionais, possibilitando assim uma visão prática mais abrangente. São eles o Hospital Escola Municipal de São Carlos, o Hospital do Câncer de Barretos, a Santa Casa de Porto Alegre e a Santa Casa de São João da Boa Vista. Desta forma, espera-se então entender se nos hospitais destinados ao atendimento público a presença da arquitetura, por meio de requisitos básicos, é eficiente na humanização dos ambientes. E. por fim, fornecer subsídios para a estruturação de uma arquitetura hospitalar mais eficiente na questão da humanização.

Palavras-chave: edifícios hospitalares: humanização; arquitetura hospitalar: projetos hospitalares: João Filgueiras Lima; Lelé; utente; conforto. 

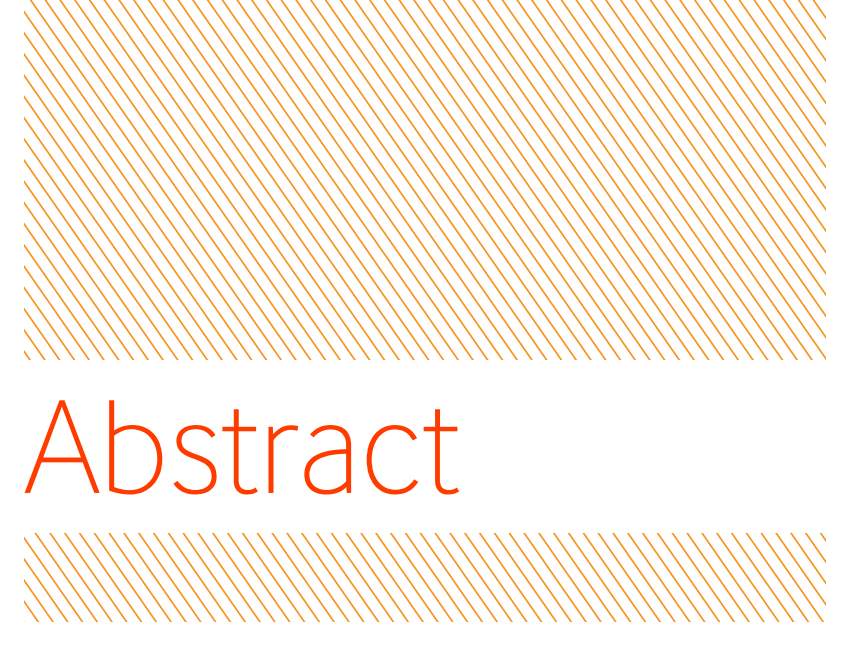

CIACO, R. J. A. S. (2010). The architecture in the process of humanization of hospitalar ambients. Tesis (Master). Escola de Engenharia de São Carlos, Universidade de São Paulo, São Carlos, 2010.

The matter of hospitalar humanization seems to be subject quite recurring nowadays in the sciences of health, as well as in architecture. This study aims to understand through the architecture point of view the structuring and the practices of the humanization processes within the hospitalar ambient. For this intention, it will be realized theoretical incursions for better precise the concept of humanization in an architectonical approach, either through the patient or the employee of the health area perspectives, as well as it will be revised the legislation about the subject in order to better comprehend the function of the Sistema Único de Saúde (SUS) within the process of hospitala humanization. Still through a theoretical approach, it is expected to establish parameters that make possible to evaluate if the health buildings either or not can be considered humanized, trying to map the basic requirements for the development of an efficient architecture focused on the humanization of hospitalar ambients.

From this theoretical approach of the hospitalar humanization within its relationship with architecture a field analysis is implemented in order to verify in the hospitalar practices if there is a real concern in developing and implementing an architecture focused on the humanization, as well as if the architectonic requirements identified in the theory were enough to reflect an architecture with this intention.

Our hypothesis is that since the public hospitals have lower availability of resources, the concern with the humanization is exclusively related to the essential and basic principles of an architecture worried with the issue, being these architectonic requirements enough for ensuring an adequate leve of humanization of the hospital ambient. Thus the analysis corpus will be the public health system considering four hospitals that serve preferentially SUS patients, with different sizes and complexity of operation: Hospital Escola Municipal de São Carlos, Hospital do Câncer de Barretos, Santa Casa de Porto Alegre and Santa Casa de São João da Boa Vista. We expect to understand if in these public hospitals the presence of the basic architectonic requirements are enough and sufficient for the humanization of the ambients. At last, we intend to provide contribution for the development of a hospitalar architecture more efficient and worried with the question of humanization.

Key words: hospitalar edifice: humanization; hospitalar architecture; hospitalar project; João Filgueiras Lima; Lelé; patient; comfort. 


\section{Lista de Imagens}

\section{FIG. 1 - P.53}

Tabela ilustrativa retirada da RDC n. 50

FIG. 2 - P. 104

Implantação do Hospital Escola Municipal

de São Carlos destacando etapa da obra já

concluída109

FIG. 3 - P. 105

Fotos gerais do Hospital Escola Municipal de

São Carlos

FIG. 4 - P. 107

Foto aérea do Hospital do Câncer de Barretos

FIG. 5 - P.108

Fotos do pavilhão destinado à prevenção no

Hospital do Câncer de Barretos

FIG. 6 - P. 109

Fotos dos veículos utilizados nas campanhas de

prevenção contra o câncer em comunidades

carentes de atendimento

FIG. 7 - P. 110

Fotos das áreas destinadas a descanso e estudo

dos médicos do Hospital do Câncer de Barretos

\section{FIG. 8 - P. 112}

Folder de divulgação das formas de doação

com as quais conta o Hospital do Câncer de Barretos

FIG. 9 - P. 112

Fotos de caminhão descarregando doações feitas ao Hospital do Câncer de Barretos

FIG. 10 - P. 113

Implantação esquemática do Hospital do

Câncer de Barretos

\section{FIG. 11 - P. 115}

Fotos demonstrativas das varandas de

circulação periférica do Hospital do Câncer de

Barretos

FIG. 12 - P. 115

Fotos ilustrativas dos ambientes de uso comum

do Hospital do Câncer de Barretos

\section{FIG. 13 - P. 116}

Implantacão esquemática do complexo da Santa Casa de Porto Alegre

FIG. 14 - P. 118

Figura ilustrativa do sistema funcional orbital do complexo da Santa Casa de Porto Alegre

FIG. 15 - P. 124

Foto aérea da Santa Casa Dona Carolina

Malheiros com a construção inicial

\section{FIG. 16 - P.127}

Folder de divulgação do resultado das

campanhas para angariar fundos para reformas da Santa Casa Dona Carolina Malheiros

\section{FIG.17- P. 128}

Foto da Santa Casa Dona Carolina Malheiros

com a identificação das instalaç̃oes

FIG. 18 - P. 130

Foto ilustrativa da enfermaria destinada aos

usuários de convênios e particulares da Santa

Casa Dona Carolina Malheiros

\section{FIG. 19 - P.131}

Fotos das áreas de uso comum da ala destinada aos usuários de convênios e particulares da Santa Casa Dona Carolina Malheiros 
FIG. 20 - P. 131

Fotos ilustrativas das enfermarias masculinas e femininas destinadas ao SUS, na Santa Casa Dona Carolina Malheiros

\section{FIG. 21 - P. 132}

Fotos ilustrativas da recepção e circulação do ambulatório da Santa Casa Dona Carolina Malheiros

\section{FIG. 22 - P.132}

Fotos llustrativas do setor de radioterapia e quimioterapia da Santa Casa Dona Carolina Malheiros

\section{FIG. 23 - P. 139}

Fotos do Hospital do Câncer de Barretos mostrando piso utilizado

\section{FIG. 24 - P. 139}

Fotos da Santa Casa de Porto Alegre mostrando os pisos utilizados

\section{FIG. 25 - P. 139}

Fotos da Santa Casa Dona Carolina Malheiros mostrando os pisos utilizados

\section{FIG. 26 - P. 141}

Fotos da área destinada aos médicos -

biblioteca e setor das salas privativas no Hospital do Câncer de Barretos

\section{FIG. 27 - P. 142}

Fotos do Hospital do Câncer de Barretos - sala de descanso para médicos e enfermeiros e de estar defronte sala de estudos dos médicos

\section{FIG. 28 - P. 143}

Foto da praça central do Complexo da Santa Casa de Porto Alegre

FIG. 29 - P. 143

Foto da área de descanso dos funcionários da Santa Casa Dona Carolina Malheiros
FIG. 30 - P. 146

Foto do Hospital do Câncer de Barretos tomada via satélite

\section{FIG. 31 - P. 147}

Foto de satélite e aérea atual ilustrando situação da implantação da Santa Casa Dona Carolina Malheiros 158

\section{FIG. 32 - P. 148}

Fotos ilustrativas dos antigos espaços vazios

entre os pavilhões da Santa Casa Dona Carolina Malheiros

\section{FIG. 33 - P. 153}

Croqui ilustrativo da área em funcionamento do Hospital Escola Municipal de São Carlos com esquema das circulações

\section{FIG.34 - P. 154}

Croqui ilustrativo da implantação de todo o Hospital Escola Municipal de São Carlos com esquema de circulação

\section{FIG. 35 - P. 155}

Implantação esquemática do Hospital do

Câncer de Barretos

FIG. 36 - P. 155

Foto aérea do Hospital do Câncer de Barretos

\section{FIG. 37 - P. 156}

Esquema ilustrativo das circulações do Hospital do Câncer de Barretos

\section{FIG. 38 - P. 156}

Fotos ilustrativas das circulações técnica e externa do Hospital do Câncer de Barretos

\section{FIG. 39 - P. 157}

Foto do Hospital Dom Vicente Scherer no

Complexo da Santa Casa de Porto Alegre
FIG. 40 - P. 158

Foto do Hospital Santa Clara no Complexo da Santa Casa de Porto Alegre

\section{FIG. 41 -P.159}

Fotos ilustrativas das passarelas que ligam os hospitais do complexo da Santa Casa de Porto Alegre

\section{FIG. 42 - P. 159}

Croqui esquemático da distribuição original do

Pavimento térreo da Santa Casa Dona Carolina Malheiros

\section{FIG. 43 - P. 160}

Croqui esquemático da distribuição original do primeiro pavimento da Santa Casa Dona Carolina Malheiros

\section{FIG. 44 - P. 160}

Croqui esquemático da distribuição original do segundo pavimento da Santa Casa Dona Carolina Malheiros

\section{FIG. 45 - P. 161}

Croqui esquemático de distribuição atual do pavimento térreo da Santa Casa Dona Carolina Malheiros

\section{FIG. 46 - P. 162}

Croqui esquemático de distribuição atual

do primeiro pavimento da Santa Casa Dona Carolina Malheiros

\section{FIG. 47 - P. 162}

Croqui esquemático de distribuição atual do segundo pavimento da Santa Casa Dona Carolina Malheiros

\section{FIG. 48 - P.168}

Fotos ilustrativas das varandas externas de circulação do Hospital do Câncer de Barretos
FIG. 49 - P. 168

Fotos ilustrativas das áreas de uso comum do Hospital do Câncer de Barretos

\section{FIG. 50 - P. 169}

Fotos das áreas internas do Hospital do Câncer de Barretos

FIG. 51 - P. 170

Fotos das áreas internas dos hospitais do

complexo da Santa Casa de Porto Alegre

\section{FIG. 52 - P. 171}

Foto da vista externa, a partir das enfermarias

suS, da Santa Casa Dona Carolina Malheiros

FIG. 53 - P. 171

Foto da circulação interna da Santa Casa Dona Carolina Malheiros

FIG. 54 - P. 172

Fotos ilustrativas das enfermarias do SUS da Santa Casa Dona Carolina Malheiros

FIG. 55 - P. 172

Fotos de áreas internas de uso comum da Santa Casa Dona Carolina Malheiros

\section{FIG. 56 - P. 173}

Fotos ilustrativas do Hospital Escola Municipa de São Carlos

\section{FIG. 57 - P. 174}

Fotos ilustrativas das áreas externas do Hospita do Câncer de Barretos

FIG. 58 - P. 175

Fotos ilustrativas do complexo da Santa Casa de Porto Alegre

\section{FIG. 59 - P. 177}

Fotos ilustrativas de ambientes do complexo da Santa Casa de Porto Alegre 


\section{Sumário}

\section{Capítulo 1:}

Contextualizando a humanização

\section{Capítulo 2:}

Percursos metodológicos

31

2.1 Definição do objeto de estudo

2.2 Definição do corpus

2.3 Hipótese

2.4 Objetivo

Capítulo 3

Arquitetura e humanização: abordagens teóricas

3.1 Utente

3.2 Legislação

3.3 SUS - Sistema Único de Saúde

3.4 Humanizasus

3.5 Humanização

3.6 Arquitetura para estabelecimentos assistenciais de saúde

3.6.1 Requisitos básicos

A. Adequação ao local

B. Projeto deve resultar de um estudo funcional e técnico do problema

C. Racionalização das circulações e agrupamento de usos e atividades afns

D. Auxilio na prevenção à infecção hospitalar

E. Flexibilidade dos ambientes

F. Preocupações com o conforto ambiental

F.1. Conforto térmico

F.2. Conforto visual

G. Presença de verde

H. Relação interior $x$ exterior

I. Humanização dos espaços

3.6.2 Críticas

3.7 Relação arquitetura x humanização 


\section{Capítulo 4}

Arquitetura e humanização na prática hospitalar

4.1 Hospital Escola Municipal de São Carlos

4.2 Hospital do Câncer de Barretos

4.3 Santa Casa de Porto Alegre

4.4 Santa Casa de São Joao da Boa Vista

\section{Capítulo 5}

Abordagens teóricas $\mathrm{x}$ análises práticas: a humanização entre a teoria e a prática 135

5.1 Valorização do "olhar diferenciado" do utente

5.2 Sob a ótica da legislação

5.3 Valorização dos profissionais da saúde

5.4 Valorização dos espaços pela arquitetura

5.4.1 Adequação ao local

5.4.2 Projeto deve resultar de um estudo funcional e técnico do problema

5.43 Racionalizaç̃o das circulaços e agupamento de uso

5.4.4 Auxílio na prevenção à infecção hospitalar

5.4.5 Flexibilidade dos ambientes

5.4.6 Preocupações com o conforto ambiental

5.4.7 Presença de verde

5.4.8 Relação interior $x$ exterior

5.4.9 Humanização dos espaços

Capítulo 6

Conclusão 
Capítulo 1

Contextualizando a Humanização 
A questão da saúde pública é um assunto bastante abrangente e amplamente discutido não só na área da Arquitetura como também em outras áreas, como a médica, área da enfermagem, área da administração pública ou privada, etc. O que nos chama inicialmente a atenção, é o fato de o termo humanização estar cada vez mais presente nas discussões, tanto teóricas quanto práticas, das áreas que envolvem a saúde no país. Entender os aspectos que de alguma maneira envolvem a questão da humanização parece, ao menos por enquanto, bastante pertinente para um olhar contemporâneo sobre a saúde pública e a arquitetura hospitalar.

Um olhar atento e interessado aos jornais, revistas, mídia digital, além de pesquisas nos registros de seminários das áreas de saúde ou mesmo nas políticas públicas relacionadas à área da saúde, indica uma clara preocupação com a humanização dos espaços e serviços de saúde no Brasil.

O projeto em questão objetiva entender essa atual tendência e saber qual o papel, a importância e a pertinência da arquitetura na humanização dos espaços assistenciais de saúde no Brasil, levantando as práticas e os processos que vêm sendo adotados, visando possibilitar, desta forma, uma melhor assertividade e eficácia da arquitetura nos projetos para estabelecimentos hospitalares.

Assim, espera-se contribuir para a reflexão teórica e acadêmica sobre o papel da arquitetura na humanização dos ambientes hospitalares, buscando auxiliar também na reflexão sobre a prática dos arquitetos que trabalham na elaboração e execução de projetos de edificações para o atendimento à saúde no país, tanto públicos como privados.

O tema colocado pode ser considerado não apenas de interesse discursivo mas, antes, também absolutamente relevante do ponto de vista da prática em arquitetura. Partindo-se do princípio que a arquitetura deve se voltar para o ser humano - enquanto aquele que usufrui de seus objetos, o edifício e a cidade -, o que mais se constata na abordagem de pesquisa aqui proposta é que a arquitetura voltada para os espaços assistenciais de saúde é uma arquitetura pensada e feita para o ser humano talvez em sua condição de maior sensibilidade.

No $1^{\circ}$ Seminário de Arquitetura Hospitalar, realizado em agosto de 2003, na cidade de São Paulo, 
com o apoio da revista Projeto e Design, os temas humanização e flexibilidade dos ambientes foram o principal assunto. Arquitetos de reconhecida competência na área, como Jarbas Karman, Augusto Guelli, Carlos Eduardo Pompeu, Siegbert Zanettini e Lauro Miquelin foram os principais palestrantes.

Como evidenciou Carlos Eduardo de Pompeu, por exemplo, "o hospital tem de ser bom e parecer bom para dar a sensação de confiança" $a^{\prime \prime}$. Lembra também que médicos norte-americanos já constataram que o psiquismo é fator determinante para a rápida recuperação do paciente: "nosso psiquismo pode ser motivado ou deprimido e isso é regulado em grande parte pelas emoções."

Já o arquiteto Siegbert Zanettini, lembrou que a sensibilidade tem importante papel em qualquer projeto elaborado pelo arquiteto. Porém, no caso de ambientes hospitalares, maior atenção deve ser dada para garantir um certo equilíbrio entre os elementos e garantir um espaço mais humanizado.

O termo humanização é de difíil definição mas, tomando como simples exemplos os conceitos citados acima, talvez se comece a entender que qualquer espaço exerce influência sobre o ser humano, seja este sua residência, seu local de trabalho, de lazer etc. O que torna estes espaços humanizados é o fato de estabelecerem uma forte e significativa ligação com o seu usuário. No caso dos ambientes hospitalares, este aspecto deve ser mais forte ainda pois, os espaços são projetados para receber pessoas geralmente em estágio de recuperação no qual o fator emocional muito influi. Sendo assim, o ambiente deve propiciar ao indivíduo sensação de bem-estar e tranquilidade, que consequentemente Ihe darão a sensação de segurança e confiabilidade.

Se a definição não é imediata, é importante esclarecer que o termo humanização em nenhum momento deve ser confundido com luxo, mas sim com qualidade.

Móveis, decoração, equipamentos eletrônicos, por si sós, não garantem qualidade ao ambiente. O conjunto todo é que garante isso e não necessariamente um fator está ligado ao outro.

Deve se partir da compreensão que humanização é o conceito que dá ao ambiente a garantia de que ele influenciará no ser humano que o utilizar de maneira benéfica, acelerando, assim, suas condições de melhora.

Tal garantia se consegue por intermédio de vários fatores, como iluminação, ventilação, utilização correta de cores, mobiliário, sensação de segurança, além de tantos outros fatores.

O fator luxo ou o serviço de hotelaria, por exemplo, pode até ser um fator auxiliar para garantir ao espaço melhor qualidade, mas jamais será o mais importante ou o fator determinante.
Outro fator determinante para obtenção de qualidade do ambiente é a escolha dos materiais a serem empregados na obra. Atualmente há uma variedade de opções de materiais, que permitem garanti grande eficiência aos ambientes, tanto no quesito humanização, quanto no quesito tecnológico. Sabe-se que os ambientes hospitalares têm a necessidade de grande capacidade de adaptação flexibilidade e adequação às novas técnicas da medicina, que vêm evoluindo constantemente. Unir a tudo isso o conceito de humanização é o grande desafio do arquiteto projetista, atualmente. Grandes exemplos de sucesso neste aspecto podem ser observados nos trabalhos de Lelé (João Filgueiras Lima) e em outros hospitais que seguem sua linha de desenvolvimento.

A grande procura e demanda pelo assunto atesta o crescimento e a pertinência das questões relativas ao cuidado especializado no tratamento técnico dedicado ao projeto e à construção de espaços hospitalares mais humanizados. Outros inúmeros congressos voltados à humanização hospitalar inclusive em diferentes áreas de atuação profissional - como as da administração hospitalar medicina, enfermagem etc -, vêm acontecendo com bastante frequência.

Por exemplo, o Congresso Humanização Hospitalar em Ação, realizado em São Paulo, no ano de 2007, em sua quinta edição, começou no Brasil pela iniciativa de ONG’s e de profissionais da saúde determinados a humanizar os ambientes hospitalares e teve como apoio de conteúdo o Hospital das Clínicas (FMUSP), a instituição Doutores da Alegria e o Projeto Carmim. O Congresso Brasileiro de Enfermagem, em sua quinquagésima sétima edição, realizada no ano de 2005 na cidade de Goiânia, discutiu a importância da participação do profissional enfermeiro junto à equipe de desenvolvimento dos espaços com o objetivo de garantir melhores resultados e qualidade aos ambientes. 0 'enfermeiro' é um dos personagens mais importantes no tratamento do paciente, podendo em muito contribuir no aspecto da humanização.

Em evento promovido pelo Fórum da Construção, uma organização vinculada à arquitetura e construção civil, em dezembro de 2006, na cidade de São Paulo, o seminário "Arquitetura Hospitalar na Atualidade" contou também com a participação de diversos profissionais da área de arquitetura e alguns arquitetos considerados referenciais na área, como por exemplo, o arquiteto Jarbas Karmman. O enfoque principal foi a discussão sobre as tendências na arquitetura hospitalar e a preocupação com a humanização e eficiência do atendimento. Já a oficina "HumanizaRio", realizada em julho de 2007 na cidade do Rio de Janeiro, coordenada pelo Instituto Nacional do Câncer (INCA), abordou especificamente a questão da humanização em espaços dedicados aos cuidados com a saúde no Estado do Rio de Janeiro e à Política Nacional de Humanização Hospitalar (PNH).

Os Congressos Nacionais da ABDEH - Associação Brasileira para o Desenvolvimento do Edifício Hospitalar - geram discussões e artigos que tratam diretamente do assunto, como, por exemplo os 
artigos: A Humanização e o ambiente Físico Hospitalar; e O Invisivel de Quem Cuida: a humanização das unidades de apoio em ambientes de saúde - uma experiência em Juiz de Fora, Humanização nos Espaços Hospitalares Pediátricos: A qualidade do espaço construído e sua influência na recuperação da criança hospitalizada, ou mesmo o artigo A Cor no Ambiente Hospitalar, entre outros.

Os cursos de especialização, como o curso de especialização de arquitetura em sistemas de saúde da Universidade Federal da Bahia, também abordam a questão da humanização, como ilustra a monografia Humanização do Espaço Arquitetônico em Unidade de Hemodiálise, entre outros.

Todas essas produções que vêm sendo geradas nos últimos anos, acabam por fazer com que a bibliografia recente sobre o assunto aborde de maneira mais constante a questão da humanização do atendimento e também dos espaços assistenciais de saúde.

Há também iniciativas que partem do setor privado de saúde. Em um encontro nacional da UNIMED, uma das mais conhecidas cooperativas de prestação de serviços médicos do país, também são identificadas preocupações com a discussão sobre "humanização hospitalar". Tal discussão, neste caso, pode decorrer mais da demanda de mercado que propriamente da necessidade de melhoria do atendimento, o que pode ser preocupante, pois a qualidade do atendimento e espaços humanizados em discussão, deixam de ter seu caráter crítico e passam a ter um caráter mercadológico, o que apenas pode denotar um caráter comercial sem preocupação com os aspectos da humanização Inclusive a própria iniciativa pública através de seus planos de humanizaç̃ão do atendimento nos estabelecimentos assistenciais de saúde públicos, através de políticas como o HumanizaSUS (Política Nacional de Humanização), que é uma política nacional claramente focada nesta questão, tem demonstrado esta preocupação.

Uma segunda análise sobre o tema da Arquitetura no processo de Humanização dos Ambientes Hospitalares destina-se a entender se tal abordagem é ou não uma questão importante para a arquitetura. Através da pesquisa, pôde-se entender melhor, por exemplo a questão voltada para a legislação específica da área ou a correta especificação de materiais e tecnologias, entender as atuais e futuras abordagens projetuais da arquitetura.

Ainda, analisando-se o efetivo papel da Arquitetura no processo de Humanizaç̃o dos Ambientes Hospitalares, entender também claramente a relação dela, arquitetura, com outras disciplinas e o que esta relação pode trazer de benefícios, ou seja, compreender que outro olhar desta abordagem pode contribuir para a arquitetura. 
Capítulo 2

Percursos

Metodológicos 


\subsection{Definição do objeto de estudo}

O assunto em questão oferece uma vasta gama de opções de enfoque de pesquisa. Pode-se tanto buscar estudar elementos singulares como a utilização das cores nos ambientes, até questões complexas que envolvem ambientação, implantação e relação com o entorno.

Estudar ambientes específicos como as enfermarias, os corredores, as salas de espera, as salas de procedimentos, centros de tratamento intensivo entre tantos outros, é outra possibilidade que também abre uma variedade de opções de estudo.

A abordagem pretendidaé olhar a questão da humanização dos ambientes em ambientes assistenciais de saúde, que visem ao atendimento público. No setor público porque permitirá olhar a situação no "ambiente" mais difícil. Já no hospital privado há mais alternativas e recursos a serem utilizados, como investimentos em hotelaria, decoraç̃̃es mais luxuosos, equipamentos mais modernos, etc. Inicialmente se entende que os ambientes assistenciais de saúde públicos, são mais carentes de uma maneira geral. Ao mesmo tempo que têm um maior volume de utentes quando comparados aos estabelecimentos privados, são estabelecimentos que têm maior deficiência em inúmeros aspectos, principalmente quando se fala em recursos financeiros, o que faz com que busquem e dependam de campanhas de arrecadação de verbas, doações entre outras situaç̃̃es que muito dificultam sua administração, pois o administrador tem que cuidar de recursos com as quais nem sempre pode contar e pior, independem de sua administração para existirem ou não.

Assim, o objeto de estudo constitui-se, portanto, no ambiente assistencial de saúde voltado para o atendimento ao público do Sistema Único de Saúde, que permita estabelecer um panoramageneralizado da situação da humanização nestes espaços, panorama este que será analisado e comparado com a abordagem teórica sobre o tema para se entender realmente sua eficiência, se ela existir. 


\subsubsection{Humanização sob a perspectiva do utente}

O utente pode passar nos estabelecimentos assistenciais de saúde desde poucos minutos até anos, dependendo de sua enfermidade e recuperação. Ele pode frequentar estes estabelecimentos para um procedimento eventual, como um exame ou um atendimento de urgência; ele pode frequentar estes estabelecimentos de maneira mais constante para realizar procedimentos que necessitam de maior frequência, como, por exemplo, procedimentos de hemodiálise ou radioterapia para os quais o paciente comparece a estes estabelecimentos algumas vezes por semana; ele pode necessitar ficar internado por um período pequeno de tempo que dura um ou poucos dias para se recuperar de uma doença ou procedimento de baixa complexidade e até mesmo ele pode precisar se internar nestes estabelecimentos por longos períodos em função de doenças ou procedimentos mais complexos.

Em qualquer uma dessas situações, o indivíduo que passa a ser considerado utente, é retirado de sua rotina natural da vida e passa a ter momentos que envolvem sentimentos de angústia, medo, incerteza, insegurança, desconforto, abandono, etc. São, estes sentimentos que tornam o utente um ser fragilizado.

Quando fragilizado, tudo que se passa para ele ou mesmo tudo que ele vê, vê com um olhar diferente. É exatamente neste aspecto de olhar diferenciado que os estabelecimentos assistenciais de saúde têm que se focar para garantir a este utente uma melhor qualidade em seu tratamento e recuperação, qualidade que não pode ser vista de maneira superficial pois, qualidade nos Estabelecimentos Assistenciais de Saúde, envolve desde a qualidade primária que garante salubridade, segurança e conforto mínimo até a qualidade que vise garantir a este indivíduo uma melhor condição de recuperação, tornando assim melhor sua permanência nestes ambientes e, dentro do possível, de menor duração pois, o objetivo destes estabelecimentos é o de curar o utente e devolvê-lo a sua vida normal, no menor tempo possível.

\subsubsection{Humanização sob a perspectiva da equipe de atendimento}

Inicialmente deve-se entender o utente como o personagem principal dos estabelecimentos assistenciais de saúde, por isso tudo deve ser voltado para ele. O utente está presente nestes locais para se tratar e se curar, preferencialmente no menor tempo possível, precisando de cuidados especiais, de atendimento especial. Mas, para tudo isso acontecer na prática, uma série de outros usuários precisam estar presentes e atuantes. Estes outros usuários constituem a equipe de atendimento ou como o Ministério da Saúde chama, os trabalhadores da saúde, compreendendo desde os funcionários de apoio como recepcionistas, faxineiros, cozinheiros, etc, passando por funcionários administrativos até se chegar à categoria que atua diretamente com o utente, que é a equipe clínica dos estabelecimentos, formado por enfermeiros, psicólogos, fisioterapeutas e médicos que são os maiores responsáveis pelos procedimentos e, consequentemente, pela recuperação e tratamento dos utentes.

Enquanto o utente chega a passar grandes períodos internado ou mesmo frequentando de maneira sistemática tais estabelecimentos, estes trabalhadores da saúde, passam, na verdade, 0 tempo todo dentro destes ambientes. Para que eles possam se preocupar com os utentes e assim garantir seu melhor tratamento, estes ambientes precisam ser preparados e organizados também para garantir as melhores condições de conforto a eles também. Abordagens recentes já focam esta questão. Por exemplo, o artigo "O Invisível de Quem Cuida", gerado a partir do I Congresso Nacional da ABDEH - IV Seminário de Engenharia Clínica - 2004, trata da humanização das "áreas pouco visíveis" dos Estabelecimentos Assistenciais de Saúde - EAS, no caso, especificamente as lavanderias hospitalares.

Ainda, segundo GOLDENSTEIN, com base numa pesquisa prévia com usuários e funcionários em um hospital, trabalhando a modificação dos ambientes como pintura, iluminação, mobiliário, etc. nota-se modificações comportamentais: dos pacientes quanto das equipes de saúde; percepção por parte dos pacientes, de uma melhor atenção para com eles; aumento da ocupação dos espaços públicos, entre outras. ${ }^{3}$

A legislação em vigor, já cuida para que os ambientes de trabalho ofereçam a maior condição de segurança aos procedimentos, mas cuidado especial deve ser dado também aos ambientes de apoio destinado a estes profissionais da saúde, como as áreas de conforto médico, os refeitórios, as áreas de permanência em geral, entre outros.

\subsection{Definição do corpus}

A escolha dos hospitais a serem estudados, tem como principal parâmetro a proximidade com o trabalho, quer seja ela física, quer seja ela emocional. Proximidade física relacionada à cidade de São Carlos e São João da Boa Vista, cidades onde se desenvolve esta pesquisa e cidade de residência respectivamente. Proximidade emocional explicada pela experiência de sucesso vivida, experiência esta que em muito motivou a escolha deste tema para ingresso no programa de mestrado. Mais, experiência que coloca uma vivência prática que certamente beneficia a pesquisa.

Além desta proximidade, outro aspecto que foi analisado, foi a busca por se conseguir, dentro das possibilidades, hospitais de portes físicos diferentes, de forma a permitir um melhor entendimento 
nos diferentes contextos práticos. Somada a esta diferença de porte físico, também buscou-se por estabelecimentos de diferentes complexidades e finalidades em seu atendimento.

Os hospitais selecionados foram: o Hospital Escola Municipal de São Carlos, que atualmente encontrase somente com sua primeira etapa da obra concluída, ou seja, oferece somente atendimento ambulatorial de urgência e emergência a utentes e exames radiológicos. Desta forma, não oferece ainda nenhum leito de internação, nem executa procedimentos de maior complexidade; o Hospita do Câncer de Barretos, que oferece 80 leitos de internação, além de uma ala de atendimento ambulatorial que realiza anualmente mais de 450.000 procedimentos de baixa e alta complexidade; o complexo da Santa Casa de Porto Alegre que, apesar de seus 200 anos de existência, de oferecer mais de 1000 leitos de internação e contar com sete hospitais, sendo seis deles especializados, pode ser considerado atualmente um hospital de referência, tanto no atendimento aos usuários do SUS, quanto com relação à qualidade do tratamento oferecido. Referência esta que sai do âmbito do Estado do Rio Grande do Sul e abrange o nível nacional de referência; e a Santa Casa de São João da Boa Vista, que oferece aproximadamente 160 leitos de internação e, de certa forma constitui-se em um centro regional para as cidades adjacentes de pequeno porte que não possuem hospital. Além disso, existe há mais de 100 anos o que oferece à pesquisa um melhor entendimento da evolução e porque realiza procedimentos de alta complexidade.

Desta maneira, através destas análises práticas busca-se um embasamento das visões que permita um melhor entendimento e consequentemente, uma análise consistente. Não se opta aqui por estudo de caso destas instituições por se entender que um estudo de caso que forneça insumos mais aprofundados para a pesquisa de uma instituição, contribui para o objetivo deste trabalho menos que a análise mais geral de vários estabelecimentos.

\section{Estabelecimentos Selecionados:}

\section{Hospital Escola Municipal de São Carlos}

Hospital ainda em construção porém com sua primeira etapa de obras concluída e em funcionamento. Dois motivos foram os principais para sua escolha como estabelecimento a ser estudado: primeiro pelo fato de estar instalado na cidade de São Carlos; segundo por ser um hospital projetado por Lelé - João Filgueiras Lima.

Além disso, o Hospital Escola Municipal de São Carlos é um hospital já em funcionamento porém ainda sem a ala destinada à internação. Fato este que o coloca como o menos complexo a ser estudado pois oferece somente atendimento de emergência, ambulatórios para adultos e pedítricos e setor de exames radiológicos. Ou seja, é um estabelecimento de pequeno porte físico e baixa complexidade nos procedimentos oferecidos ao público.
Quando estiver com todas suas etapas de obra conclúidas, terá área aproximada de 30.000 metros quadrados e tem pretensão de ser referência no atendimento aos usuários do Sistema Único de Saúde (SUS). Além disso, é um hospital que visa a integrar a rede de saúde pública à rede escola-pesquisa através da Universidade Federal de São Carlos - UFSCAR, que será responsável por sua administração.

Hospital do Câncer de Barretos

O Hospital do Câncer de Barretos está localizado na cidade de Barretos, região de São José do Rio Preto, a aproximadamente $190 \mathrm{~km}$ de distância de São Carlos. É um hospital especializado no tratamento contra o câncer e nacionalmente conhecido até em função de seus pavilhões receberem nomes de artistas populares

O principal motivo de sua escolha como objeto de estudo é o fato de o Hospital do Câncer de Barretos ser referência na qualidade do atendimento ao público usuário do Sistema Único de Saúde - SUS (praticamente 100\% do volume dos utentes) e qualidade do tratamento especializado.

Éum hospital de pequeno porte físico, contém inclusive, apenas 80 leitos de internação. Embora tenha somente 80 leitos disponíveis para internação, sua capacidade de atendimento é alta pois, em função de o tratamento contra o câncer poder ser feito através de procedimentos que não demandem efetivamente internaç̃os. Por exemplo, no ano de 2008 foram realizados mais de 450.000 atendimentos para mais de 84.000 pacientes de 27 estados brasileiros com uma média aproximada de 3000 atendimentos ambulatoriais por dia.

\section{Santa Casa de Porto Alegre}

A Santa Casa de Porto Alegre é um complexo de sete hospitais e atualmente é o maior hospital do Rio Grande do Sul. Seus hospitais englobam deste os procedimentos gerais até os especializados como Hospital oncológico, neurológico, de transplantes, entre outros. Todos os sete hospitais são considerados de alta complexidade contendo cada um sua própria Unidade de Tratamento Intensivo (UTI) e centro cirúrgico.

O complexo oferece no total mais de 1000 leitos de internação sendo 60\% deles destinado aos usuários do Sistema Único de Saúde (SUS). Além disso, é considerado referência em qualidade de atendimento no Estado, qualidade esta comprovada pelas consecutivas obtenções de bons resultados nas pesquisas de qualidade do SUS e referência nacional em qualidade técnica em diversas especialidades, como neurologia, pneumologia e transplantes de órgãos.

Os dois maiores motivos que levaram esta pesquisa a selecionar este complexo como objeto de estudo foram primeiramente o fato de uma experiência pessoal nele vivida há alguns anos (2003/2004), que conforme colocado, oferece uma vivência que contribui com a pesquisa e em segundo lugar por ser o complexo referência na qualidade de atendimento, qualidade que, pela experiência vivida, de antemão já se comprova 
Santa Casa Dona Carolina Malheiros de São João da Boa Vista

A Santa Casa de São João da Boa Vista, é um hospital de médio porte e considerado de alta complexidade, que atende toda a região de São João da Boa Vista. Nela há 156 leitos para internação sendo 70\% destinados ao Sistema Único de Saúde (SUS), há centro cirúrgico, maternidade e Unidade de Tratamento Intensivo (UTI).

Este hospital caracteriza-se por ser o retrato da Santa Casa tradicional, voltada para atendimento preferencial da população local, onde trabalham os médicos com forte ligação com a cidade, geralmente com dedicação de praticamente toda a vida profissional e assim como as Santas Casas em geral, atravessa sucessíveis crises inclusive financeiras, que hora ou outra colocam a instituição em dificuldades de manutenção e sobrevivência.

O principal motivo pela sua escolha como objeto de estudo, é o fato de ser também o hospital da cidade de residência do pesquisador, o que impõe estreitos laços de ligaç̃o e entendimentos pois nela já fora internado algumas vezes, além dos inúmeros comparecimentos para procedimentos simples ou simplesmente como mero acompanhante de algum utente. Sendo assim, da mesma forma que o estabelecimento anterior, oferece ao trabalho uma vivência prática que proporciona insumos eficientes para a pesquisa.

Desta maneira, através destes quatro objetos de estudo, busca-se fechar um panorama de análise que visa estudar estabelecimentos de baixa, média e alta complexidade e de pequeno, médio e grande porte físico, o que muito embasa as visões deste estudo.

\subsection{Hipótese}

Inicialmente, aparentemente a questão da humanizaç̃ão dos ambientes parece dividida, no olhar da arquitetura, em dois grandes eixos: o primeiro que privilegia mais as questões voltadas para decoração, hotelaria, luxo; o segundo só tem os requisitos básicos (adequação ao local, projeto deve resultar de um estudo funcional e técnico do problema, racionalização das circulações e agrupamento de usos e atividades afins, auxilio a prevenção à infecção hospitalar, flexibilidade dos ambientes, preocupações com o conforto ambiental, presença de verde, ralação entre interior e exterior e humanização dos espaços) de uma arquitetura voltada pra a humanizacão, que são desprovidos de decoracão, luxo, etc. para garantir sua eficiência.

A primeira linha, mais voltada para a questão da decoração, luxo, etc. naturalmente é voltada para um público mais selecionado que por esse diferencial pode pagar, através de tratamentos particulares ou mesmo através de convênios de saúde.

A segunda linha de raciocínio, quando coloca os requisitos básicos, entre outros coloca as questões voltadas para conforto térmico e acústico, relação entre interior e exterior, presença de paisagismo, utilizaç̃o adequada de cores, etc como elementos que garantam aos ambientes uma boa qualidade e consequentemente boa influência sobre os indivíduos que frequentam tais ambientes.

Tal linha não exclui necessariamente o uso de uma decoração mais privilegiada ou mesmo um certo grau de sofisticação em seus ambientes. O que precisa ficar claro é que tais elementos devem ser vistos como elementos acessórios e que não garantem necessariamente a qualidade do ambiente. Deve-se buscar a qualidade através de elementos básicos (requisitos) e após alcançado tal objetivo, sofisticá-lo ou não.

O que existe muito atualmente, são ambientes onde os elementos aqui colocados como sofisticados acabam por compensar a falta dos tais requisitos básicos, como por exemplo, uma climatização artificial para corrigi falta de eficiência na ventilação ou não correta implantação e insolação, esquadrias com alta tecnologia para garantir vedação contra rúdos externos gerados por uma adequaç̃o ao local não eficiente ou mesmo para resolver o problema de insolação em excesso, entre outras situações possíveis como claramente comenta TOLEDO: As tentativas de humanização do atendimento hospitalar podem ser encaradas como uma primeira reação à hegemonia do hospital tecnológico e vêm sendo levadas a efeito com diferentes graus de profundidade e abrangência. ${ }^{4}$

A hipótese é a de que em hospitais de atendimento ao públicos há preocupação com a questão da humanização dos ambientes mas, em função da menor disponibilidade de recursos, esta preocupação se volta exclusivamente para os princípios essenciais da humanização - os requisitos básicos. Estes princípios por si só já são suficientes para garantir um nível adequado de qualidade arquitetônica no ambiente hospitalar. relativamente à humanização.

\subsection{Objetivo}

Como objetivo principal, busca-se entender se a preocupação com a questão da humanização dos ambientes existe nos hospitais que visam ao atendimento público e, em ela existindo, saber se é, de fato eficiente. Entender se, em tais hospitais, a presença da arquitetura voltada para os requisitos básicos, aquela que se preocupa com ventilação eficiente, iluminação eficiente, presença de verde (paisagismo), relação entre interior e exterior dos ambientes, etc. é eficiente na humanização dos ambientes hospitalares.

Como objetivos secundários, busca-se primeiramente mapear quais são os requisitos básicos utilizados nos hospitais voltados para o atendimento ao público e que serão estudados; em segundo lugar, fornecer elementos e subsídios para o desenvolvimento de projetos arquitetônicos hospitalares dos Estabelecimentos Assistenciais de Saúde voltados para a humanização, bem como trabalhos na área que visem a esta questão. 
Capítulo 3

Arquitetura e Humanização: Abordagens Teóricas 


\subsection{Utente}

Em termos de humanização dos ambientes hospitalares, antes de se analisar qualquer questão relacionada à arquitetura, é de fundamental importância entender-se que um dos elementos mais importante de todo o conjunto é o utente e que tudo que se objetiva fazer em relação à qualidade do atendimento, da arquitetura, de recursos de segurança etc., é voltado para o utente. Ele tem que ser o foco principal da análise: qualquer argumento analítico que o deixe de lado, será inócuo e em nada contribuirá para uma discussão consequente sobre a qualidade aos ambientes.

Analisando a evolução histórica das características dos ambientes assistenciais de saúde, vê-se uma constante transformação no conceito de utente. 0 utente deixou de se instalar nesses ambientes para morrer, como nas chamadas "salles de mourir", para se colocar em ambientes que têm como objetivo tratá-lo, curá-lo e trazê-lo rapidamente de volta ao exterior, como claramente coloca BITTENCOURT:

O hospital passou a ter uma função terapêutica, deixando de ser um lugar terminal para o doente. transformando-se num objeto de preocur diretamente relacionada às suas propriedades 5

Hospital é, hoje, o local onde se internam e se tratam doentes, ou seja, o local agrega, com o tempo, a "função terapêutica", função que foi adquirindo com a evolução dos métodos da medicina. Atualmente, a preocupação da medicina ultrapassa o objetivo terapêutico, alcançando, além da função de recuperar a saúde do paciente, também a preocupação com a qualidade desta recuperação, para a qual contribui, de modo determinante, a qualidade de vida durante a internação, bem como no tempo que ela dura e na influência que ela exerce sobre os acompanhantes dos pacientes - que muito contribuem nessa recuperação. CARPMAN, deixa este argumento bastante claro, como citado a seguir

De acordo com Carpman, Grant e Simmons (1986 apud MEDEIROS; LUCIANA DE, 2004, p. 44), um projeto humanístico de arquitetura deve contemplar o ponto de vista de pacientes e visitantes. Para alcancar esse fim arauitetos e demais planejadores devem considerar a internaç̃o das pessoas com seus ambientes e consequentement 
ao serem submetidos a algum procedimento e ao entrarem em contato com adversidade/quantidade de aparatos e pessoas presentes no local. Segundo os autores, as necessidades dos pacientes e visitantes

são levadas em conta quando aspectos são obedecidos: sinalizaç̃ão, conforto físico, possibilidade de regular o contato social e cuidado com o significados transmitidos pelo ambiente ${ }^{6}$

Pode-se então, concluir que, de modo geral, sem vínculo especial com determinadas enfermidades ou mesmo com o tipo de hospital, a evolução do modo como se compreende os ambientes hospitalares pode ser resumido na seguinte sequência: local para tratamento dos doentes > ambiente para o tratamento e recuperação dos utentes > e, atualmente, ambiente dedicado ao tratamento e recuperaç̃o dos utentes com a maior qualidade e em menor tempo possível.

Há, ainda hoje, estabelecimentos de saúde voltados para os pacientes terminais, como, por exemplo, os hospitais especializados no tratamento oncológico. Obviamente, nem todos têm esta finalidade e sim a terapêutica, mas os que tem. buscam transformar estes momentos finais em instantes menos dolorosos, tanto para os utentes quanto para seus acompanhantes.

Vale citar importante observação de GHEZZI, na qual o autor explica, de maneira bem clara, o porquê da denominação paciente, aqui sempre colocado como utente, ao indivíduo doente que se interna nos hospitais:

O termo paciente é empregado tanto pela enfermagem como pelos médicos com justificada propriedade. uma vez que recebe a ação praticada por um agente, ou ainda a pessoa doente, sob cuidados médicos. ao invés da palavra doente, que quer dizer apenas pessoa que tem doenç̧a ${ }^{7}$.

Por outro lado - e de uma forma geral -, os ambientes assistenciais de saúde evoluíram e continuam evoluindo em função do constante desenvolvimento das técnicas e equipamentos médicos que geralmente condicionam as inovaç̃̃es arquitetônicas, associando evolução tecnológica ao maior conforto do utente:

Segundo Devlin e Arneill (2003 apud MEDEIROS; LUCIANA DE, 2004, p.57), a evolução do hospital e sua nova imagem modificada pelas tecnologias e humanização dos espaços gerou o aparecimento de edifícios que primam pelo conforto do paciente ${ }^{8}$.

Tomando como exemplo o conforto luminoso, embora tenha sido objeto de constante aprimoramento projetual - tanto no que se refere à iluminação natural quanto à artificial -, com a evolução dos equipamentos e dos sistemas luminotécnicos, faz-se necessária a constante pesquisa para um aperfeiçoamento cada vez maior das condicõos de sua aplicacão, tendo em vista a necessidade de concebê-los conforme as demandas de conforto luminoso do paciente - e não mais como recurso que atende exclusivamente às demandas dos procedimentos e cuidados médicos. O mesmo acontece em relação ao conforto térmico, visual, acústico, à ventilação natural, à ventilação artificial etc, conforme mostram CORBELLA \& YANNAS e SAMPAIO nas citações abaixo:

Com relaç̃o ao conforto visual, além da quantidade de luz ter que ser adequada para que a realização de tarefas visuais aconteça de maneira satisfatória, é fundamental que não haja ofuscamento (..) nem grandes

O conforto acústico está relacionado com a qualidade do som produzido no ambiente, ou seja, se esse som produzido é audível satisfatoriamente pelos seus ocupantes, e com a não interferência de rúdos

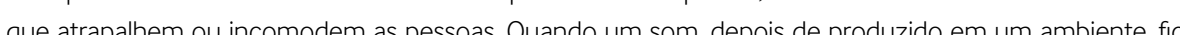
que atrapalhem ou hcomodem as pessoas. Quando um som, depois de produzido em un ambiente, fica

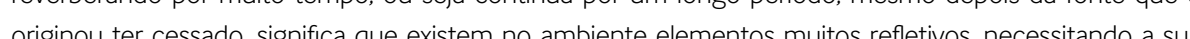
onginou ter cessado, signica que existem no ambente elementos mulos rentelivos, necessitando a su substituição por elementos mais absorventes para que haja uma maior satisfação e sensação de bemestar. Se rúdos externos interferem nas atividades desenvolvidas em um ambiente, um melhor isolamento acústico como o aumento da massa do fechamento ou o amortecimento através de um material que diminui o impacto na superficie onde ocorre o ruído pode ser eficaz ${ }^{10}$.

Embora atualmente encontrem-se disponíveis inúmeras ferramentas e sistemas tecnológicos para garantir a eficiência desses ambientes em relação aos utentes que abrigam, há, contudo, algumas preocupações que se remetem às premissas de projeto: alguns recursos de projeto que lidam com aspectos mais amplos, recursos projetuais não esquecidos por grandes arquitetos - como Rino Levi. Lelé (João Filgueiras Lima) e outros -, e que não podem deixar de ser considerados para se obter uma perfeita adequação dos resultados. Pode-se citar, por exemplo, o estudo cuidadoso da implantação do edifício, estudo de fluxos, estudo funcional e técnico do problema, flexibilidade da construção criação de espaços verdes "...flexibilidade das instalaç̃os, padronização de elementos da construção e iluminação natural e conforto térmico, entre outros."1"

A constante evolução nas técnicas e dos equipamentos médicos parece fazer com que a preocupação com a humanização seja cada vez maior. Pode-se perceber esta preocupaç̃o, por exemplo, na Política Nacional de Humanização (PNH), promovida pelo Ministério da Saúde desde o ano de 1998, articulada em planos de voluntariado como os "Doutores da Alegria", que têm grande repercussão nos meios de comunicação e mesmo nos filmes acessíveis à população como um todo, como a película americana "Path Adams: 0 Amor é Contagioso", que fala sobre tratamentos mais humanos para os pacientes de um hospital dos Estados Unidos. Tais exemplos mostram que é comum a preocupação com a Humanização dos ambientes hospitalares - que não se trata apenas de uma preocupação só com o espaço, mas também com o atendimento e com o preparo dos médicos e enfermeiros. Também fica claro, principalmente no exemplo do "Doutores da Alegria", que a tão buscada humanização hospitalar 
está acontecendo, nestes casos, por iniciativas próprias de grupos voluntários, sem necessariamente a intervenção direta do poder público - que apenas respalda a iniciativa. O que é importante salientar é que a humanização hospitalar tem que atender a estes três aspectos, de modo concomitante: promocão de melhorias técnicas nos ambientes construídos, melhorias nas suas condições de uso e instalação e no melhor preparo dos profissionais de atendimento.

\section{A preocupação com a Humanização existe - e isto está bastante claro.}

Ainda, algumas iniciativas vêm sendo tomadas, ou por grupos voluntários isolados ou, ainda, pela iniciativa privada. No caso da iniciativa privada, o preocupante é que a tão buscada melhoria na qualidade do atendimento e humanização dos espaços é encarada como um diferencial de marketing. Portanto, a humanização não é encarada como busca pela melhoria na recuperação do paciente, mas como artifício e argumento de venda ou então, muitas vezes, confundida com luxo ou melhores serviços de hotelaria: "... existe uma tendência em comparar a estrutura de determinados hospitais à de hotéis, atribuindo-thes a qualidade de 'humanizado' devido à variedade das opções de serviço de conforto oferecido ao paciente" ${ }^{\text {"12. }}$.

O fato é que a preocupação com a humanização dos ambientes hospitalares faz-se inequivocamente presente, independentemente do fato de estar ou não sendo operacionalizada e transformada em ações.

Nos seminários e congressos de arquitetura hospitalar - como a / e // Semana de Arquitetura Hospitalar, realizadas em 2005 e 2006 pela revista PROJETO DESIGN -, o assunto sempre esteve em pauta. Conforme a manifestação de renomados arquitetos nesta área - como João Carlos Bross, Jarbas Karman ou Siegbert Zanettini, que atualmente são referências na área de projetos e construções hospitalares -, o assunto aparece como uma constante preocupação.

Os hospitais são comumente vistos como locais de doença - e não de saúde. É isso que lhes conforma o caráter e também, forçosamente, caracteriza seu usuário como um utente: alguém que sofre a intervenção de um agente externo que lhe administra uma ação terapêutica. Só este fato já é suficiente para desencadear um quadro de estresse que agrava as condições fisicas e psicossomáticas do utente. Daí a importância de um projeto humanizado, que alivie sua angústia. Com ele, o objetivo deveria ser o de criar espaços saudáveis, que tragam sensação de bem-estar e proporcionem boa relação entre o ser humano e o meio. Essas metas podem ser alcançadas, dentre outras formas, com a ajuda de uma série de recursos projetuais como, por exemplo, implantação adequada, boa dosagem de aberturas protegidas e com insolação adequadamente dimensionada, projeto paisagístico, recursos da psicodinâmica da cor, considerando até mesmo diferenças de sexo e idade, como coloca CAPMAN:
CAPMAN et al.(1986 apud SAMPAIO, ANA VIRGINIACARVALHÃES DE FARIA, p. 198) fazem recomendaç̄ẽes com relação às áreas externas. Se possível, todos os ambientes devem ter acessos a áreas sombreadas, com fontes de água vegetocão local ad to do o confortel para sentar para que possam caminar com fontes de água, vegetaçăa, local adequado e confotavel para sentar, para que possam caminhar acompanhados de enfermetros e acessivel para caderas de rodas e macas. No caso de pacientes que não possam ir para fora, as janelas devem permitir o contato com o exterior, para que eles possam identificar as diferentes épocas do ano, horas do dia e o tempo, se chuvoso, nublado ou ensolarado. ${ }^{13}$

Está claro que uma concepção diferenciada e o desenvolvimento técnico dos equipamentos fizeram com que os profissionais da área de arquitetura, medicina e administração percebessem de maneira diferente toda a problemática envolvida no planejamento desses espaços. Também está clara a preocupação em melhorá-los cada vez mais. O que se torna necessário, então, é um "outro olhar" sobre técnicas atuais para se conseguir novos e mais efetivos resultados para os projetos arquitetônicos de saúde. Até mesmo porque "a previsão e detecção precoce de falhas ou defeitos coíbem interrupções e interdições evitáveis e mobilização e dispêndios desnecessários." ${ }^{\text {"I Inclusive }}$ "...hospitais são muito caros para serem utilizados com ineficiência."15

\subsection{Legislação}

Art. 196, da Constituição Federal: A saúde é direito de todos e dever do Estado, garantido mediante políticas sociais e econômicas que visem à redução do risco de doença e de outros agravos e ao acesso universa igualitário às acõoes e sevviços para sua promoção, proteç̃ão e recuperação.

TOLEDO, em seu livro "Feitos Para Curar", transcreve uma entrevista feita com Regina Barcellos e Flávio Bicalho, profissionais com efetiva participação na elaboração das normas nacionais voltadas para os Estabelecimentos Assistenciais de Saúde.

Embora haja iniciativa anterior (1965) que demonstra que já havia preocupação com a legislação no Brasil, pelo que se pode concluir em funcão da entrevista, o início na normatização para os EAS no Brasil começou na década de 70 com a denominada Portaria no. 400 que tinha como título "Normas para instalações de Hospitais Gerais até 150 Leitos".

Tal portaria na verdade tinha uma abordagem parecida com as normas da ABNT. Nela havia a listagem de ambientes por unidade, com dimensionamento e observações básicas de necessidade, proximidade e circulação de pessoas e insumos.

Com a Constituição de 1988, a área da saúde teve uma mudança geral, onde se estabeleceu com clareza o dever do Estado de atender toda a população na questão da saúde. Estes avanços 
decorreram do movimento chamado Reforma Sanitária que culminou em 90 com a Lei Orgânica da Saúde, que definiu o SUS (Sistema Único de Saúde), com suas competências nos níveis federal, estadual e municipal - conceito de vanguarda e de difíili implantação. 0 sistema incorpora uma série de idéias, dentre as quais podemos destacar a participação da comunidade, o planejamento ascendente, o enfoque na prevenção, a descentralização do serviço.

A criação da portaria no. 1.884, em 1994, veio com o objetivo de proporcionar maior liberdade e flexibilidade ao projetista quando da elaboração dos EAS. É uma norma que, de certa maneira, pode ser entendida como um quebra-cabeça onde há inúmeras peças que permitem então montar várias propostas e desenhos, cada uma particular e normatizada.

Os entrevistados também colocam no desenvolvimento da entrevista, várias tendências que visualizam no setor:

O edifício tem influência na forma de agir das equipes médica e de enfermagem e também no paciente, permitindo a ele recuperar sua saúde em um ambiente agradável. Desta forma demonstra que o edifício, como um produto arquitetônico, pode vir a ter um papel importante no processo de cura.

- Crescimento dos serviços de saúde especializados. Percebe-se uma fragmentação nos serviços. Ta colocação pode ser observada nos hospitais da Rede SARAH, no Hospital do Câncer de Barretos e mesmo na Santa Casa de Porto Alegre, onde todo o complexo é dividido em vários prédios e cada um tem um papel e funcionamento independente. Mais que isso: tal experiência mostra que esta situação contribui em muito para elevar o padrão de atendimento ao paciente, geralmente público (SUS) e consequentemente uma melhora no seu processo de cura.

- Terceirização de serviços de apoio, tais como lavanderia, esterilização. Com a normatização eficiente em vigência, tais ambientes podem perfeitamente ser instalados em locais independentes ao EAS de maneira a permitir melhor utilização do espaço disponível, grande dificuldade atual, principalmente nos hospitais dos grandes centros.

Lei orgânica de saúde

A lei no. 8080 de setembro de 1990, conhecida como Lei Orgânica da Saúde, é a lei que define o Sistema Único de Saúde - SUS e suas atribuiç̃oes.

Ela coloca as disposições gerais, os objetivos e atribuições, os princípios e diretrizes, a organização, direção e gestão, competências, e atribuições do SUS especificamente; coloca o funcionamento e a participação complementar dos serviços privados de assistência à saúde; coloca a organização dos recursos humanos; e recursos, gestão financeira, planejamento e orçamento de financiamentos.

No artigo $4^{0}$, fica clara a descentralização do conjunto de ações e serviços de saúde prestados po órgãos e instituições públicas e coloca que a iniciativa privada poderá participar do Sistema Único de Saúde em caráter complementar.

Estão incluídas no campo de atuação do Sistema Único de Saúde - SUS, a execução das açães de vigilância sanitária, vigilância epidemiológica, de saúde do trabalhador e assistência terapêutica integral, inclusive farmacêutica; a participação na formulação da política e na execução de ações de saneamento básico; a ordenação da formação de recursos humanos na área de saúde; a vigilância nutricional e a orientação alimentar; a formulação da política de interesse para a saúde e a participação na sua produção; o controle e a fiscalização de serviços, produtos e substâncias de interesse para a saúde; a fiscalização e inspeção de insumos para consumo humano dentre outros.

Com relação aos princípios e diretrizes, de acordo com a Constituição Federal, as ações e serviços públicos de saúde e serviços privados contratados obedecem aos princípios de universalidade de acesso aos serviços de saúde; integralidade de assistência; preservação da autonomia das pessoas: igualdade da assistência à saúde, direito à informação, participação da comunidade, descentralização político-administrativa. Dá ênfase na descentralização dos serviços para os municípios, regionalização e hierarquização da rede de serviços de saúde, conjugação dos recursos financeiros, tecnológicos, materiais e humanos da União à saúde da população e capacidade de resolução dos serviços em todos os níveis de assistência, entre outros.

Relativamente à organização, direção e gestão, a lei coloca que a direção do Sistema Único de Saúde - SUS, será exercida em cada esfera de governo pelos órgãos do Ministério da Saúde no âmbito da União, pelas Secretarias de Saúde ou órgão equivalente no âmbito dos Estados e Distrito Federal e pelas respectivas Secretarias de Saúde ou órgãos equivalentes no âmbito dos Municípios.

A lei ainda coloca as atribuições comuns entre a União, os Estados, o Distrito Federal e os Municípios, a competência exclusiva da direção nacional do Sistema Único de Saúde - SUS, a direção estadual do Sistema Único de Saúde e a direção municipal do Sistema Único de Saúde.

Entre as várias competências da direção nacional do SUS estão: participar na formulação e implementação das políticas como saneamento básico ou condições relativas aos ambientes de trabalho; definir e coordenar os sistemas de redes integradas de assistência de alta complexidade de rede de laboratórios de saúde pública, de vigilância epidemiológica e sanitária; participar da definição de normas e mecanismos de controle; coordenar e participar na execução das ações de 
vigiância epidemiológica; promover articulação com os órgãos educacionais e de fiscalização do exercício profissional; prestar cooperação técnica e financeira aos Estados, ao Distrito Federal e aos Municípios; elaborar normas para regular as relações entre o SUS e os serviços privados; promover a descentralização dos serviços e ações de saúde; elaborar planejamento estratégico nacional em cooperação técnica com os Estados, Municípios e Distrito Federal; e estabelecer o Sistema Nacional de Auditoria.

Entre as várias competências da direção estadual do SUS estão: promover a descentralização para os Municííios dos serviços e das ações de saúde; acompanhar e avaliar as redes hierarquizadas do SUS: prestar apoio técnico e financeiro aos Municípios; coordenar e, em caráter complementar, executar ações e serviços de vigilância epidemiológica e sanitária, de alimentação e nutrição e de saúde do trabalhador; identificar estabelecimentos hospitalares de referência e gerir sistemas públicos de alta complexidade, de referência estadual e regional; e estabelecer normas em caráter suplementar.

Entre as várias competências da direção municipal do SUS estão: participar em articulação com a sua direção estadual do planejamento, programação e organização da rede regionalizada e hierarquizada do SUS; executar serviços de vigilância epidemiológica e sanitária, de alimentação e nutrição, de saneamento básico e de saúde do trabalhador; formar consórcios administrativos intermunicipais: gerir laboratórios públicos de saúde e hemocentros; celebrar contratos e convênios com entidades prestadoras de serviços privados de saúde, bem como controlar e avaliar sua execução; controlar e fiscalizar os procedimentos dos serviços privados de saúde; e normatizar complementarmente as aç̃es e serviços públicos de saúde no seu âmbito de atuaç̃o.

Com relação aos serviços privados de assistência à saúde, a lei coloca diretrizes de funcionamento e da participação complementar.

Relativamente às diretrizes do funcionamento, o artigo 20 dispõe que tais serviços, os privados, caracterizam-se pela atuação por iniciativa própria na promoção, proteção e recuperação da saúde: o artigo 21 que a assistência à saúde é livre à iniciativa privada; o artigo 22, que na prestação de serviços, serão observados os princípios éticos e as normas expedidas pelo órgão de direção do SUS quanto às condiç̃̃es para seu funcionamento; $\mathrm{e}$ o artigo 23 dispõe que é vedada a participação direta ou indireta de empresas ou de capitais estrangeiros na assistência à saúde com algumas ressalvas.

Relativamente à participação complementar, o artigo 24 estabelece que quando as suas disponibilidades forem insuficientes para assistir à população de uma determinada área, o SUS poderá recorrer aos serviços ofertados pela iniciativa privada; segundo o artigo 25, as entidades filantrópicas e as sem fins lucrativos terão preferência para participar do SUS; e o artigo 26 coloca que os critérios e valores para remuneração de serviços serão estabelecidos pela direção nacional do SUS.
O artigo 27 diz claramente que a política de recursos humanos na área da saúde será formalizada e executada pelas diferentes esferas de governo.

A lei ainda traz, através de seus artigos 31 a 38, a normatização para obtenção, gestão e planejamento de recursos.

Portaria no 1884 - do Ministério da Saúde

A portaria no. 1884, de 11 de novembro de 1994, dispõe que, através do Ministério de Estado da Saúde, em função da necessidade, sobre as formas de atualizar as normas existentes até então na área de infra-estrutura física em saúde; em funcão da necessidade de dotar as Secretarias Estaduais e Municipais de instrumento norteador que atenda aos princípios de regionalização, hierarquização acessibilidade e qualidade da assistência prestada à população; a necessidade das Secretarias Estaduais e Municipais contarem com um instrumento de avaliação de projetos físicos, adequado às novas tecnologias na área da saúde, resolve aprovar normas destinadas ao exame e aprovação de Projetos Físicos de Estabelecimentos Assistenciais de Saúde pública ou privada para as construções novas, as áreas a serem ampliadas e as reformas

De maneira mais técnica e até mesmo didática, esta portaria estabelece de maneira bastante eficiente os critérios para: a elaboraç̃ão dos projetos físicos; a programação físico-funcional dos Estabelecimentos Assistenciais de Saúde; a quantificação, dimensões especiais e instalações prediais dos ambientes; as circulações internas e externas; as condições ambientais de conforto; os ambientes funcionais dos Estabelecimentos Assistenciais de Saúde que demandam obscuridade; as condicões ambientais de controle de infeccão hospitalar; e as condicões de segurança contra incêndio. Além disso, coloca no adendo uma lista de eficientes tabelas que em função da população básica dos Estabelecimentos Assistenciais de Saúde (paciente, doador, funcionário, aluno, público e seus respectivos sub-grupos) estabelece as unidades/ambientes necessários bem como seu dimensionamento (quantificação e dimensão) e suas respectivas instalações básicas.

Para a elaboração de projetos físicos, a portaria coloca que todos os projetos de estabelecimento assistencial de saúde - EAS terão que ser elaborados em conformidade com as suas disposições relativas à̀ terminologia (estudo preliminar, projeto básico e projeto executivo); etapas de projeto; responsabilidades apresentação de desenhos e documentos; tipos e siglas adotadas; e aprovação de projeto.

Para programação físico-funcional dos estabelecimentos assistenciais de saúde, a metodologia utilizada é a apresentação da listagem do conjunto das atribuições e atividades do EAS, nela tratado genericamente, sem compromisso com soluções padronizadas visando apresentar aos projetistas e avaliadores um leque das diversas atividades e os ambientes respectivos em que elas ocorrem. 
Esta listagem contém as atribuiç̃es e atividades com a qual se pode montar o estabelecimento desejado de maneira a definir estabelecimentos específicos, ficando desta maneira, a decisão do tipo de estabelecimento a ser implantado a cargo dos gestores e técnicos e não mais de acordo com padrões pré-estabelecidos nacionalmente.

Para a quantificação, dimensões especiais e instalações prediais dos ambientes, a resolução aborda os aspectos espaciais estritamente relacionados com as diversas atribuiç̃ôes e atividades dos Estabelecimentos Assistenciais de Saúde. Entende que o ambiente é entendido como espaço fisicamente determinado e especializado para o desenvolvimento de determinada atividade, caracterizado por dimensões e instalações diferenciadas. São enfocados os aspectos relativos ao dimensionamento e às instalações necessárias a cada ambiente. 0 dimensionamento é expresso pela dimensão espacial (superfície e dimensão mínima) e a quantificação refere-se ao número de vezes que o mesmo ambiente se repete.

Aos critérios para projetos de estabelecimentos assistenciais de saúde, são apresentadas variáveis que orientam e regulam as decisões a serem tomadas nas diversas etapas de desenvolvimento de projeto. São elas: circulações externas e internas; condições ambientais de conforto; condições ambientais de controle de infecção hospitalar; instalações prediais ordinárias e especiais; e condições de segurança conta incêndio.

A portaria ainda coloca que, para determinação das relações entre as diversas atribuições do Estabelecimento Assistencial de Saúde faz-se necessário reconhecer as categorias de pessoas usuárias e circulantes no estabelecimento, que, via de regra, definirão os fluxos e acessos. As categorias para esta população são: paciente (interno e externo), doador (de sangue ou leite humano), funcionário (administrativo ou assistencial), aluno (técnico, graduação, pós-graduação e estágio) e público (acompanhante de paciente, visitante de paciente, fornecedor de materiais, prestador de serviços, vendedor de materiais e serviços e visitante)

A partir daí, são colocadas as tabelas das unidades funcionais, tabelas estas que discriminam a atividade, unidades/ambientes, dimensionamento (quantificação e dimensão) e as instalações. As unidades funcionais constantes desta resolução são: ações básicas de saúde; ambulatório atendimento imediato (atendimentos de emergência e urgência); internação (geral, recém-nascido, intensiva e para tratamento de queimados); apoio ao diagnóstico e terapia (patologia clínica, imagenologia, métodos gráficos, anatomia patológica, medicina nuclear, centro cirúrgico, centro obstétrico, reabilitação, hemoterapia/hematologia, radioterapia, quimioterapia, diálise e banco de leite); apoio técnico (nutrição e dietética, farmácia e central de material esterilizado); ensino e pesquisa; apoio administrativo; e apoio logístico (processamento de roupa, central de administração de materiais e equipamentos, manutenção, conforto e higiene, limpeza e zeladoria).
A seguir, de forma ilustrativa, segue uma das tabelas citadas: Desta forma, conforme colocaram

\begin{tabular}{|c|c|c|c|c|}
\hline No ATTV. & UNIDADE / AMBIENTE D & DIMENSIONAMENTO & & INSTALAÇOÉES \\
\hline & & $\begin{array}{l}\text { QUaNTIFICACăo } \\
\text { (min.) }\end{array}$ & DIMENSÄO(min.) & \\
\hline \multirow[t]{2}{*}{ 3.1;3.2. } & $\begin{array}{l}\text { Atendimentos de } \\
\text { Emergencia e Urgencia } \\
\text { (cont) }\end{array}$ & & & \\
\hline & $\begin{array}{l}\text { Emergèncias (atta } \\
\text { complexidade) e Urgências }\end{array}$ & & & \\
\hline 3.2 & 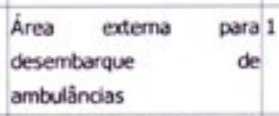 & & $\begin{array}{l}21,00 \mathrm{~m}^{2} \text { de área } \\
\text { coberta }\end{array}$ & \\
\hline 3.2 & $\begin{array}{l}\text { Área de recepsä́ de } 1 \\
\text { pacientes }\end{array}$ & & $\begin{array}{l}\text { suficiente } \\
\text { recelinento de } 1 \\
\text { marca }\end{array}$ & \\
\hline 3.2 .4 & Salh de senviso social & 1 & $8,0 \mathrm{~m}^{2}$ & \\
\hline 3.2 .2 & Sols de higienizaç̧̄o & & $8,0 \mathrm{~m}^{2}$ & HF;HQ \\
\hline 3.2 .4 & $\begin{array}{l}\text { Posto de erfermagem /1 } \\
\text { prescriç̆óo médica }\end{array}$ & $\begin{array}{l}1 \text { para cada } 12 \text { letos } \\
\text { de coservasaja. }\end{array}$ & $\operatorname{tos} 6,0 \mathrm{~m}^{2}$ & HF \\
\hline 3.2 .4 & Sala de serviços & $\begin{array}{l}\text { Coda posto deve ser } \\
\text { serniso por zo menos } \\
1 \text { sala. }\end{array}$ & $\sec 8,0 \mathrm{~m}^{2}$ & HF \\
\hline 3.1 .4 a 3.1 .7 & Sola de isolamento & 1 & $8,0 \mathrm{~m}^{2}$ & HF;HQ;FO;FAM;EE \\
\hline \multicolumn{5}{|l|}{3.24 a 3.2 .7} \\
\hline $\begin{array}{l}3.1 .4 \text { a } 3.1 .7 \mathrm{e} \\
3.2 .4 \text { a } 3.2 .7\end{array}$ & $\begin{array}{ll}\text { Sola coletive de } \\
\text { observaçá } \\
\text { pediatria/adolescente de }\end{array}$ & $\begin{array}{l}1 \text { de pedilatria, } 2 \text { de } \\
\text { aduito-(mas e fem). } \\
\text { no de lentos e } \\
\text { calculado sobre a } \\
\text { estimativa }\end{array}$ & $\begin{array}{l}\text { de } 8,5 \mathrm{~m}^{2} \text { por lete } \\
0 \\
\dot{e} \\
\dot{e}\end{array}$ & HF;FOFAM;EE \\
\hline $\begin{array}{l}3.1 .4 \text { a } 3.1 .7 \mathrm{e} \\
3.2 .4 \text { a } 3.2 .7\end{array}$ & $\begin{array}{l}\text { Salas coletiva ded } \\
\text { observaçó de oduito - } \\
\text { masculina e feminina }\end{array}$ & $\begin{array}{l}\text { do total de } \\
\text { - otendmentos de } \\
\text { emergencias } \\
\text { urgencia }\end{array}$ & $\begin{array}{l}\text { de } 8,5 \mathrm{~m}^{2} \text { por leito } \\
\text { de } \\
\text { e }\end{array}$ & HF;FOFAMM;EE \\
\hline \multirow[t]{2}{*}{$\begin{array}{l}\text { 3.1.5 a 3.1.7e } \\
\text { 3.2.1.3.2.2.3 } \\
\text { 3.2.7 } \\
\end{array}$} & $\begin{array}{l}\text { Sala de procedimentos } \\
\text { especiais (imasinos) }\end{array}$ & & $20,0 \mathrm{~m}^{2}$ & $\begin{array}{l}F O ; F N ; F U C ; \\
F A M ; A C ; E E ; E D\end{array}$ \\
\hline & Área de escovaço & $\begin{array}{l}2 \text { tomeiras por sala } \\
\text { invaswor }\end{array}$ & ala 1,10 $\mathrm{m}^{2}$ por tomeira & HF;HQ \\
\hline 3.2 .5 & $\begin{array}{l}\text { Sala de gesso e reduyăo } 1 \\
\text { de fraturas }\end{array}$ & & $\begin{array}{l}12,0 \quad \mathrm{~m}^{2} \text { quardo } \mathrm{H} \\
\text { destinado a mais de } 1 \\
\text { paciente= } 8,5 \mathrm{~m}^{2} \text { por } \\
\text { box }\end{array}$ & \\
\hline $3.2 .1 ; 3.2 .3$ & 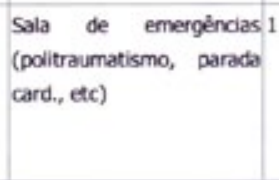 & & 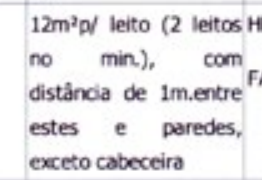 & $\begin{array}{l}\text { HF;F;:FN;FNC; } \\
\text { FAM;AC;EE }\end{array}$ \\
\hline
\end{tabular}


Regina Barcellos e Flávio Bicalho: "é uma norma que de certa maneira pode ser entendida como um quebra-cabeça onde há inúmeras peças que permitem então montar várias propostas e desenhos, cada uma particular e normatizada".

Resolução - RDC n 50 - da ANVISA

A constante evolução das técnicas e tecnologias da área da saúde faz com que as normas vigentes rapidamente fiquem defasadas. Em função disso elas precisam ser atualizadas com a maior frequência possível, conforme comenta TOLEDO:

O maior problema da normatização, segundo Lelé, é que as normas não têm acompanhado, com a velocidade necessária, as transformacões que ocorrem, a cada dia, nos tratamentos e demais procedimentos hospitalares, e muito menos a evolução dos equipamentos. Desta forma, torna-se extremamente dificil para os arquitetos que não convivem com a rotina de uma unidade hospitalar. manter-se em dia com estas transformações, uma vez que o acesso a informações, para a maioria dos projetistas, se limita àquelas que já foram codificadas."

A norma que está em vigor atualmente desde 2002, é a RDC no. 50 e é a norma que regulamenta o planejamento físico de todos estabelecimentos assistenciais de saúde - EAS. TOLEDO muito didaticamente explica a norma:

De acordo com a RDC no.50 (ANVISA, 2004, P.38), a composição funcional de um EAS varia em função de suas atribuições específicas, tais como:

1 Prestação de atendimento eletivo de assistência à saúde em regime ambulatorial e de hospital dia - atenção à saúde incluindo atividades de promoção, prevenção vigilância à saúde da comunidade e atendimento a pacientes externos, de forma programada e continuada;

2 Prestação de atendimento imediato de assistência à saúde - atendimento a pacientes externos em situaç̧ões de sofrimento, sem risco de vida (urgência) ou com risco de vida (emergência),

3 Prestação de atendimento de assistência à saúde em regime de internação- atendimento a pacientes que necessitam de assistência direta programada por período superior a 24 horas (pacientes internos):

4 Prestação de atendimento de apoio ao diagnóstico e terapia - atendimento a pacientes internos e externos em ações de apoio direto ao reconhecimento e recuperação de estado de saúde (contato direto);

5 Prestação de serviços de apoio técnico - atendimento direto e assistência à saúde em funções de apoio (contato indireto);

6 Formação e desenvolvimento de recursos humanos e de pesquisa - atendimento direto ou indiretamente relacionado à atenção e assistência à saúde em funções de ensino e pesquisa;
7 Prestaçãodeserviçosdeapoioàgestãoe execuçãoadministrativa-atendimentoaoestabelecimento em funções administrativas:

8 Prestação de serviços de apoio logístico - atendimento ao estabelecimento em funções de suporte operacional.

As quatro primeiras atribuiç̃oes relacionadas são atribuições-fim, isto é, elas constituem funções diretamente ligadas à atenção e à assistência à saúde. As quatro últimas são atribuições-meio para o desenvolvimento das primeiras e de si mesmas. A cada atribuicão, por sua vez corresponde um grande número de atividades e subatividades que se desenvolvem nos ambientes hospitalares ${ }^{18}$

De fato, a RDC no. 50 veio, em 2002, substituir a Portaria no. 1884 de 11 de novembro de 1994 Na verdade não foi exatamente uma substituição, mas uma atualização, aprofundamento e complementação da portaria anterior (no. 1884). Comparando-se as duas, vê-se que são praticamente a mesma, porém a segunda apresenta um grau de detalhamento e abrangência maior.

Entre inúmeros complementos, pode-se colocar, por exemplo, que, no item elaboração de projetos físicos, a RDC no. 50 faz, além das exigências constantes na Portaria no. 1884, a exigência de um parecer técnico (visando a adequação do projeto arquitetônico às atividades propostas pelo EAS, como funcionalidade do edifício, dimensionamento dos ambientes, instalações ordinárias e especiais e especificacão básica dos materiais). procedimentos (item voltado para elucidar situacõoes que esgotam todas as possibilidades de cumprimento integral da norma) e condições para obras financiadas por Órgãos Públicos.

Além de mais completa, sua conformação atual, embora tenha o mesmo conteúdo, é mais didática e favorável, muito mais voltada para o público técnico das áreas da arquitetura e das engenharias do que a Portaria no. 1884. Ainda há muito a ser atualizado nas portarias, mas ela continua atendendo ao seu objetivo, que é permitir a montagem de inúmeras propostas de desenhos de forma particular e normatizada.

De qualquer forma, a adequação total dos estabelecimentos às normas ainda continua sendo uma tarefa difícil, e mais, conforme comenta TOLEDO, o fato de projetos buscarem ou mesmo oferecerem qualidade a estes estabelecimentos já os colocariam mais próximos da legislação.

As exigências feitas pela Resolução quanto ao conteúdo das etapas projetuais nada mais são do que aquelas necessárias à elaboraçãao de um projeto arquitetônico de boa qualidade. Devemos reconhecer, no entanto, que apenas raramente tais exigências são cumpridas na integra, ainda que se trate de uma edificação complexa como o hospital, em que a falta de um bom projeto redunda, inúmeras vezes, en falhas de dificil correção, que podem produzir agravos importantes à saúde dos pacientes e dos próprios funcionários da unidade. ${ }^{1}$ 


\subsection{SUS - Sistema Único de Saúde}

o SUS - Sistema Único de Saúde - é o sistema de saúde pública vigente atualmente no Brasil e foi criado com a Constituição de 1988, que diz, no:

Art. 196: A saúde é direito de todos e dever do Estado, garantido mediante políticas sociais e econômicas que visem à redução do risco de doença e de outros agravos e ao acesso universal e igualitário às ações e serviços para sua promoção, proteção e recuperação.

Art. 197: São de relevância pública as ações e serviços de saúde, cabendo ao poder público dispor, nos termos da lei, sobre sua regulamentação, fiscalizaç̃ã e controle, devendo sua execução ser feita diretamente ou através de terceiros e, também, por pessoa física ou juŕdica de direito privado.

Art. 198: (*) As ações e serviços públicos de saúde integram uma rede regionalizada e hierarquizada e constituem um sistema único, organizado de acordo com as seguintes diretrizes:

I- descentralização, com direção única em cada esfera de governo;

\| - atendimento integral, com prioridade para as atividades preventivas, sem prejúź dos senvicos assistenciais III - participação da comunidade.

Parágrafo único. 0 Sistema único de Saúde será financiado, nos termos do art. 195, com recursos de orçamento da seguridade social, da União, dos Estados do Distrito Federal e dos Municípios, além de outras fontes

(*) Emenda Constitucional no. 29, de 2000.

Art. 199: A assistência à saúde é livre à iniciativa privad.

$\$ 1^{0}$. As instituiç̧ões privadas poderão participar de forma complementar do Sistema Único de Saúde, segundo diretrizes deste, mediante contrato de direito público ou convênio tendo preferência as entidades filantrópicas e as sem fins lucrativos.

$\mathbf{S} \mathbf{2}^{\mathbf{2}}$.E vedada a destinação de recursos públicos para auxilios ou subvençōes às instituições privadas com fins lucrativos.

\$3. É vedada a participaçăo direta ou indireta de empresas ou capitais estrangeiros na assistência à saúde no Pais, salvo nos casos previstos em lei.

§4. A lei disporá sobre as condições e os requisitos que facilitem a remoção de órgãos, tecidos e substâncias humanas para fins de transplante, pesquisa e tratamento, bem como a coleta, processamento e transfusão de sangue e seus derivados, sendo vedado todo tipo de comercialização.

Art. 200: Ao Sistema Único de Saúde compete, além de outras atribuições, nos termos da lei:

I - controlar e fiscalizar procedimentos, produtos e substâncias de interesse para a saúde e participar da produção de medicamentos, equipamentos, imunobiológicos, hemoderivados e outros insumos:

\|l - executar as açōes de vigilância sanitária e epidemiológica, bem como as de saúde do trabalhador:
III - ordenar a formação de recursos humanos na área de saúde:

IV - participar da formulação da política e da execução das aç̃oes de saneamento básico:

V - incrementar em sua área de atuação o desenvolvimento científico e tecnológico;

$\mathrm{VI}$ - fiscalizar e inspecionar alimentos, compreendido o controle de seu teor nutricional, bem como bebidas e águas para consumo humano,

VII - participar do controle e fiscalização da produção, transporte, guarda e utilização de substâncias e produtos psicoativos, tóxicos e radioativos.

VIII - colaborar na proteç̃o do meio ambiente, nele compreendido o do trabalho. ${ }^{20}$

Com a Lei Orgânica de Saúde, Lei no. 8080 de 1990, o SUS tem sua regulamentação. Ela regula em todo o território nacional, as aç̃oes do SUS, estabelecendo as diretrizes para seu gerenciamento e descentralização e detalhando as competências de cada esfera governamental. Dentre uma série de definições, garante a gratuidade das ações e dos serviços nos atendimentos públicos e privados contratados e conveniados ao SUS.

O SUS vem sendo implementado como processo social em permanente construção. Embora sua constituição formal tenha acontecido na Constituição de 1988, suas origens são registradas a partir da crise do modelo médico assistencial privativista hegemônico da segunda metade do século passado. Tal modelo se caracterizava por: extensão de cobertura previdenciária, privilegiar a prática médica curativa e individual em detrimento das ações coletivas; criação de um complexo médico-industrial e pelo deslocamento da prestação dos serviços médicos a entes privados lucrativos e não-lucrativos.

Com as mudanças políticas e econômicas ocorridas nas décadas de 1970 e 1980, este modelo teve seu esgotamento. 0 processo de redemocratização do Brasil estabelece novos rumos às políticas públicas e faz surgir novos atores sociais, que propõem um novo modelo de atenção à saúde: os primeiros projetos de medicina comunitária concebidos pelas secretarias estaduais de saúde e instituições acadêmicas, além de, paralelamente, iniciarem-se as primeiras experiências de municipalização da saúde.

Em 1971, é criado o Funrural (Fundo de Assistência e Previdência do Trabalhador Rural) que incorpora a população rural ao sistema de prestação de serviços. Em 1972, tem início, na cidade de Montes Claros, norte de Minas Gerais, um projeto experimental com o objetivo de buscar modelos de extensão de cobertura. Do sucesso deste projeto piloto, surge o Piass (Programa de Interiorização das Ações de Saúde e Saneamento) que provavelmente foi a primeira grande experiência brasileira de extensão de cobertura a baixo custo e com integração interinstitucional.

20 BRASIL (2003, p. 20 e 21) 
Em 1978, foi formulada a Declaração de Alma-Ata, através da Conferência Internacional sobre Cuidados Primários de Saúde, em Alma-Ata no atual Cazaquistão. Tal declaração expressa a necessidade de ação urgente de todos os governos e da comunidade mundial para promover a saúde de todos os povos do mundo.

Em 1986, acontece no Brasil o evento político-sanitário mais importante da segunda metade do século passado: a VIII Conferência Nacional de Saúde, na qual foram lançadas as bases de um novo Sistema de Saúde, bases estas que serviram de referência à elaboração da Seção da Saúde da Constituição Federal de 1988

Em 1987, é implantado o Sistema Unificado e Descentralizado de Saúde (Suds) que busca incorporar alguns elementos da proposta da reforma sanitária: a universalização; a descentralização aos estados; e a democratização das instâncias gestoras.

Em 1988, cria-se o Conselho Nacional de Secretarias Municipais de Saúde (Conasems) que unto com o Ministério da Saúde e o CONASS (Conselho Nacional de Secretários de Saúde) compõem a Comissão Intergestores Tripartite (CIT), colegiado responsável pela gestão do SUS.

\section{Como princípios básicos, o SUS tem:}

Descentralização das aç̃oes de saúde e o seu caráter participativo. Tendo o Brasil dimensões continentais, é natural que existam especificidades regionais. Desta forma, a parceria com os Estados e Municípios torna-se fundamental.

Universalidade: o SUS deve atender a todos, sem distinções ou restrições, sem qualquer custo.

Integralidade: o SUS deve oferecer a atenção necessária à saúde da população, promovendo ações contínuas de prevenção e tratamento aos indivíduos e às comunidades, em quaisquer níveis de complexidade.

Equidade: o SUS deve disponibilizar recursos e serviços com justiça, de acordo com as necessidades de cada um, canalizando maior atenção aos que mais necessitam.

Participação social: é direito e dever da sociedade participar das gestões públicas em geral, particularmente da saúde pública, e dever do poder público garantir as condições para essa participação.

De maneira bastante objetiva, o Ministério da Saúde resume os vinte primeiros anos de existência do SUS: em 1988, o SUS foi criado; em 1990, foi regulamentado: em 1993, foi extinto o INAMPS (Instituto Nacional de Assistência Médica da Previdência Social) e regulamentado o processo de descentralização da gestão dos serviços e ações do SUS; em 1994, é criado o Programa Saúde da Família: em 1996, é implantada a distribuição gratuita de medicamentos aos portadores de HIV em 1997, é criado o Sistema Nacional de Transplantes; em 1998, é instituído o Piso de Atenção Básica para viabilizar a organização da atenção básica à saúde nos municípios brasileiros; em 1999, é criada a ANVISA - Agência Nacional de Vigialância Sanitária; é estabelecido, no país, o medicamento genérico, e tem início a Campanha Nacional de Vacinação contra gripe, tétano e difteria, para a Terceira Idade; em 2000, é criada a ANS - Agência Nacional de Saúde Suplementar em 2001 o Brasil alcança a marca de 150 mil Agentes Comunitários de Saúde, antecipando a meta prevista para o fim de 2002; é aprovada a Norma Operacional de Assistência à Saúde NOAS - que define a regionalização e a descentralização da assistência à saúde; em 2003, é criado o Serviço de Atendimento Móvel de Urgência (SAMU); em 2004, é instituída a Política Nacional de Humanização do Sistema Único de Saúde (HumanizaSUS), é lançado o programa "Brasil Sorridente", que visa melhorar as condições de saúde bucal da população brasileira, é lançado, também, o programa "Farmácia Popular do Brasil" e é publicada a Política Nacional de Atenção Integral à Saúde da Mulher; em 2006, é incorporada a vacinação contra rotavírus no Calendário Básico de Vacinação da Criança e lançada a Política da Pessoa Idosa; em 2007, é lançado o Programa Mais Saúde - PAC e é lançado o Programa Nacional de Telesaúde e, em 2008, são implantadas as aç̃̃es do "Programa Mais Saúde - PAC: Saúde direito de todos".

Após mais de vinte anos de criação do SUS, o Ministério da Saúde divulga avaliação do Sistema através da opinião da população. Entre os itens aprovados pela população estão: acolhimento, acessibilidade e atendimento com qualidade aos usuários; gestão competente e transparente no setor Saúde; Valorização e educação continuada dos profissionais; participação e controle social com os conselhos de saúde; financiamento estável com recursos federais, estaduais e municipais; respeito às diferenças étnicas e culturais; pesquisa, tecnologia e inovação nos serviços e ações de saúde; regulação com eficiência do setor privado; vigilância permanente em saúde, ambiental e sanitária; e mais saúde para a populacão com políticas públicas integradas.

Entre os itens desaprovados pela população estão: falta de recursos financeiros para a saúde má gestão de recursos públicos e corrupção; demora na fila do atendimento; falta de respeito aos direitos dos usuários; pouca fiscalização por parte dos órgãos competentes e da sociedade obras inacabadas e equipamentos que não trazem melhorias; prejuízo para os cofres públicos e superfaturamento; metas dos programas não cumpridas; falta de política de recursos humanos e de concurso público; e serviços em condições precárias e sem profissionais. 
De fato, o SUS trouxe ao Brasil maior qualidade na área da saúde pública. Muito se evoluiu o que é reconhecido inclusive internacionalmente. Nesta questão, porém há muito, ainda, a evoluir. o SUS é um sistema de sucesso, foi implantado com sucesso, mas está, e sempre estará, em busca aprimoramento

Ao SUS cabe a tarefa de promover, proteger e recuperar a saúde, garantindo atenç̃oo qualidade contínua aos indivíluos às coltividades de forma equitativa ${ }^{21}$

\subsection{HumanizaSUS - política nacional de humanização do SUS}

Em 2002, com o SUS já em funcionamento há mais de 10 anos, uma avaliação de seu funcionamento foi feita pelo Ministério da Saúde, no texto A Política de Saúde no Brasil nos anos 90: Avanços e Limites.

Nele, o problema da desigualdade regional na oferta de serviços foi colocado como um problema crônico. No campo do custeio, o processo de descentralização e do regionalismo fez muito para que se estabelecessem mecanismos mais justos de alocação de recursos. Alguns programas do Ministério da Saúde, naquela época, lidaram com o desafio de aumentar a capacidade instalada do sistema, como o Programa de Apoio à Implantação de Sistemas Estaduais de Referência Hospitalar para o Atendimento de Urgência e Emergência, o Programa de Gestante de Alto Risco, o Programa de Reequipamento Hospitalar e o Projeto Expande Centro de Alta Complexidade em Oncologia. Ao passo em que a política de custeio caminhava coerentemente com os investimentos, os mecanismos de financiamento e de aplicação de recursos mostravam-se preocupantes naquele momento.

A desigualdade na distribuição e na qualificação dos recursos humanos consistia em grande obstáculo. Para sua superação, o Programa de Interiorização do Trabalho em Saúde visava alocar profissionais de medicina e enfermagem nos municípios, o Programa Saúde da Família tornou-se um instrumento para facilitar a permanência de profissionais nos municípios de menor porte e o Projeto de Profissionalização dos Trabalhadores da Área de Enfermagem buscavam a melhoria da qualificação, conforme sintetiza a colocação abaixo:

A manutenç̃̃o de gastos permanentes com treinamento e atualização dos profissionais de saúde, voltados para o atendimento mais dedicado será um desafio constante para os próximos administradores. ${ }^{22}$
O avanço da descentralização abriu perspectivas de grande desenvolvimento no gerenciamento do SUS, pela inserção de atores e pela maior possibilidade de participação social. Desta forma concluiu-se que, na década que se iniciava (2000), a saúde estava em melhores condições de executar suas políticas e gerar bons resultados.

O HumanizaSUS - Política Nacional de Humanização da atenção e gestão do SUS (2003) surge atrelado ao compromisso de uma efetivação real do Sistema Único de Saúde, partindo do reconhecimento do "SUS que dá certo".

Por humanização, o Ministério da Saúde compreende a valorização dos diferentes sujeitos envolvidos no processo de produção de saúde - usuários, trabalhadores e gestores. Como valores principais desta política estão a autonomia e o protagonismo dos sujeitos, a coresponsabilidade entre eles, os vínculos solidários e a participação coletiva no processo de gestão. Um SUS humanizado significa um SUS em todas suas instâncias, programas e projetos comprometidos com a humanização.

Como princípios norteadores, a Oficina Nacional de HumanizaSUS 'Construindo A Política Nacional de Humanização', realizada em 19 e 20 de novembro de 2003, colocou, de maneira bastante objetiva, que a política de humanização tem:

- Valorização da dimensão subjetiva e social em todas as práticas de atenção e gestão no SUS

- Fortalecimento de trabalho em equipe multiprofissional;

Apoio à construção de redes cooperativas, solidárias e comprometidas com a produção de saúde e com a produção de sujeitos:

- Co-responsabilidade desses sujeitos nos processos de gestão e atenção;

- Fortalecimento do controle social com caráter participativo; e

- Compromisso com a democratização das relações de trabalho e valorização dos profissionais de saúde

Com a implementação desta política, foram trabalhadas quatro marcas a serem consolidadas:

- Redução das filas e tempo de espera com ampliação do acesso e atendimento acolhedor e resolutivo baseados em critério de risco: 
- Todo usuário do SUS deve saber quem são os profissionais que cuidam de sua saúde e os serviços de saúde se responsabilizam por sua referência territorial;

As unidades de saúde devem garantir a informação ao usuário, o acompanhamento de pessoas de sua rede social e os direitos do código dos usuários do SUS;

As unidades de saúde devem garantir gestão participativa aos seus trabalhadores e usuários e educação permanente aos trabalhadores.

Como estratégia geral, a política nacional de humanização coloca vários eixos de ação:

No eixo das instituições do SUS, busca-se que a Política Nacional de Humanização faça parte do Plano Nacional, dos Planos Estaduais e Municipais dos vários governos;

no eixo da gestão dos trabalhos, busca-se a promoção de aç̃es que assegurem a participação dos trabalhadores nos processo de discussão e decisão, com o objetivo de fortalecer e valorizar os trabalhadores, sua motivação, auto-desenvolvimento e crescimento profissional;

no eixo do financiamento, busca-se integração de recursos vinculados a programas específicos de humanização:

no eixo da atenção, busca-se uma política incentivadora do protagonismo dos sujeitos e da ampliação da atenção integral à saúde:

no eixo da educação permanente, busca-se que a Política Nacional de Humanização componha o conteúdo profissionalizante na graduação, pós-graduação e extensão em saúde, vinculando-a aos polos de Educação Permanente e às instituiç̃̃es de formação:

no eixo da informação e comunicação, busca-se a inclusão da Política Nacional de Humanização no debate da saúde; e

no eixo da gestão da Política Nacional de Humanização, busca-se o acompanhamento e avaliação sistemáticos das ações realizadas, estimulando a pesquisa relacionada às necessidades do SUS na perspectiva da humanização.

Como parâmetros de acompanhamento de sua implementação buscaram-se:

Na atenção básica: elaboração de projetos de saúde individuais e coletivos para usuários e sua rede social; incentivo às práticas promocionais da saúde; formas de acolhimento e inclusão do usuário, que promovam a otimização dos serviços, o fim das filas, a hierarquização de riscos e o acesso aos demais niveis do sistem.

Na urgência e emergência, nos pronto-socorros, pronto-atendimentos, assistência pré-hospitalar e outros: demanda acolhida, através de critérios de avaliação de risco, garantindo o acesso referenciado aos demais níveis de assistência; garantia de referência e contra-referência, resolução da urgência e emergência, provindo o acesso à estrutura hospitalar e a transferência segura conforme a necessidade dos usuários: e definição de protocolos clínicos, garantindo a eliminação de intervenções desnecessárias e respeitando a individualidade do sujeito.

Na atenção especializada: garantia de agenda extraordinária em função da análise de risco e das necessidades do usuário; critérios de acesso; otimização do atendimento aos usuários, articulando a agenda multiprofissional em ações diagnósticas e terapêuticas, que impliquem diferentes saberes; e definição de protocolos clínicos, garantindo a eliminacão de intervenções desnecessárias.

Na atenção hospitalar: foram estabelecidos dois níveis crescentes - B e A - para adesão à Política Nacional de Humanização.

Parâmetros de nível B: existência de Grupos de Trabalho de Humanização com plano de trabalho definido; garantia de visita aberta, através da presença do acompanhante e de sua rede social; mecanismos de recepção com acolhimento aos usuários; mecanismos de escuta para a população e trabalhadores; equipe multiprofissional (ao menos médico e enfermeiro) de atenção à saúde para seguimento dos pacientes internados, com horário pactuado para atendimento à família ou sua rede social; existência de mecanismos de desospitalização, visando alternativas às práticas hospitalares como as de cuidados domiciliares; garantia de continuidade de assistência com sistema de referência e contra-referência.

Parâmetros de nível A: Grupo de trabalho de Humanização com plano de trabalho implantado garantia de visita aberta; ouvidoria funcionando; equipe multiprofissional (ao menos médico e enfermeiro) de atenção à saúde para seguimento dos pacientes internados e com horário pactuado para atendimento à família ou sua rede social; existência de mecanismos de desospitalizacão visando alternativas às práticas hospitalares como as de cuidados domiciliares; garantia de continuidade de assistência com sistema de referência e contra-referência; Conselho Gestor Local, com funcionamento adequado; existência de acolhimento com avaliação de risco nas áreas de acesso; e plano de educação permanente para trabalhadores com temas de humanização. 
Até então, a Política Nacional de Humanização tratou a questão da humanização de forma muito mais voltada para as relações interpessoais que dos espaços físicos. Com este foco de atuação, a Política trata a questão da Ambiência.

Ambiência na saúde refere-se ao tratamento dado ao espaço físico entendido como espacco social profissional e de relaçães interpessoais que deve proporcionar atenç̧ão acolhedora, resolutiva e humana. ${ }^{23}$

O conceito de ambiência, no entendimento do Ministério da Saúde, segue três eixos que devem estar sempre integrados na composição do ambiente: o espaço que visa à confortabilidade: o espaço que possibilita a produção de subjetividades; e o espaço usado como ferramenta facilitadora do processo de trabalho (otimização de recursos, atendimento humanizado, acolhedor e resolutivo).

Existem componentes que atuam como modificadores e qualificadores do espaç, estimulando a percepção ambiental e, quando utilizados com equilibrio e harmonia, criam ambiências acolhedoras propiciando contribuiç̣ões significativas no processo de produção de saúde. ${ }^{24}$

A ambiência pode ser uma importante ferramenta que propicia a mudança no processo de trabalho, desde que não seja discutida isoladamente, uma vez que ela se relaciona com a postura e o entendimento desses processos e práticas já instituídos e adotados na rotina pelos trabalhadores e gestores.

Outro fator importante para sua utilização eficiente é a interface com outros dispositivos da Política Nacional de Humanização.

Com relação à Atenção Básica, os espaços precisam ser pensados de forma que estimulem a integração das equipes de trabalho através da criação de áreas que possam ser compartilhadas pelas equipes, como, por exemplo, os espaços de acolhimento de entrada, as áreas de encontros entre trabalhadores e entre trabalhadores e usuários.

Relativamente ao dispositivo Visita aberta, vale colocar a incorporação nos projetos, de espaços que sejam capazes de acolher os visitantes, como por exemplo espaços de espera; o conceito que permita ao visitante ou acompanhante fácil acesso a sanitários e bebedouros; até mesmo espaços que permitam ao utente, em condições, receber visitas fora do leito.

Quando se coloca o dispositivo Direito a acompanhante, pode-se buscar que existam espaços capazes de acolhê-lo nos diversos ambientes das unidades (pronto-socorros, centro cirúrgicos, UTIs, etc.) e também ter espaços que permitam momentos de encontros, diálogos, relaxamento e entretenimento, como assistir televisão ou ouvir música.
Com relação à informação, sinalização e acessibilidade, os ambientes devem contemplar projetos de sinalização e placas de informaç̃oes de toda ordem que tenham linguagem clara e representativa. As sinalizações devem conduzir os usuários que estejam a caminho dos equipamentos de saúde.

Quando se pensa o trabalhador nos serviços de saúde, é importante que as áreas de apoio para o trabalhador estejam bem localizadas, seja em número suficiente e para todos os profissionais. As áreas de apoios e serviços de apoio, além de adequadas funcionalmente, devem propiciar espaços de trabalho prazerosos.

Quando a questão é acolhimento, pressupõe-se a criação de espaços de encontros entre os sujeitos, espaços que permitam a interação entre usuários e trabalhadores, entre trabalhadores e trabalhadores e entre os próprios usuários, que sejam acolhedores também no sentido de conforto, produzindo pela introdução de vegetação, iluminação e ventilação naturais, cores, artes e demais questões já mencionadas. Também vale colocar a utilização de mobiliários que sejam confortáveis e suficientes e que estejam dispostos de maneira a promover interação entre os usuários, além de equipamentos que permitam a informação ao usuário em espera.

No âmbito do pronto-socorro, é importante que se tenham propostas arquitetônicas com um arranjo que esteja de acordo com o arranjo proposto na atenção e que auxilie na resolutividade do atendimento e da organização do processo de trabalho dentro desses setores de urgência e emergência.

Além de todos esses conceitos colocados para a Política Nacional de Humanização, vale lembrar que há inúmeros projetos paralelos e complementares que visam a humanização, como por exemplo a proposta "Visita Aberta e Direito a Acompanhante, o programa "Humanização do Parto: Humanização no Pré-Natal e Nascimento" ou mesmo o "Prêmio HumanizaSuS David Capistrano" que visa reconhecer as experiências que dignificam a saúde pública e que valorizam o usuário e o trabalhador da saúde.

\subsection{Humanização}

Humanização: um conceito tão utilizado e veiculado na área arquitetônica, consciente ou inconscientemente, porém de difícil definição.

Arquitetura e humanização estão, ou deveriam estar, intimamente ligadas não só conceitualmente. 
mas também na prática. O mais importante em termos de concepção de espaços arquitetônicos é a sua adequação ao usuário, ao ser humano que os utilizará.

A edificação deve atender a uma série de anseios materiais e psicológicos dos seus ocupantes, sendo imperioso, portanto, que a construção reúna as qualidades minimamente necessárias para que sejam atendidas as condições básicas de segurança, de saúde, de higiene e de bemestar dos usuários.

O que torna um ambiente 'humanizado' são atributos que Ihe conferem escala e características compatíveis com as dimensões fisiológicas, psicológicas e morfológicas que o indivíduo carrega em si, assegurando alguma capacidade que este ambiente tem de interagir de maneira benéfica, agradável com o seu usuário. Onde quer que o ser humano esteja, em uma casa popular, em um apartamento, em um escritório, em um consultório ou em um hospital, qualquer que seja este ambiente, se ele interagir positivamente com seu usuário, pode-se entendê-lo como sendo um ambiente humanizado.

Partindo-se para a arquitetura hospitalar, que é o foco desta pesquisa, pode-se entender que este conceito ganha contornos mais restritos. Mas, de qualquer maneira, o seu sentido sempre será o mesmo: interação positiva entre ser humano e ambiente. Importante salientar que "... curar é diferente de cuidar. O cuidado com o paciente é tão importante quanto a sua cura, muitas vezes não alcançada"25. Quando se pensa nestes termos, "cuidar" explica melhor que "curar" o que enfatizamos como interação entre indivíduo e ambiente.

\section{TOLEDO coloca muito bem a importância da humanização nos ambientes hospitalares:}

Em geral, é nesse edifício que nos conscientizamos de nossas fragilidades, impotências e solidão diante da doença, e tambeem que podemos vir a encontrar a coragem, a solidariedade e a esperança necessárias ao processo de cura. A humanização do edifício hospitalar é condição imprescindível para que esses sentimentos positivos floresçam, ajudando-nos a superar o estresse, a mitigar a dor e a abreviar o momento da alta. 26

O termo humanização é de difícil definição, mas, tomando como simples exemplos as colocaç̃es citados acima, talvez se comece a entendê-lo: qualquer espaço exerce influência sobre o ser humano, seja ele sua residência, seu local de trabalho, de lazer etc. O que torna estes espaços humanizados é o fato de eles estabelecerem uma forte e boa ligação com o seu usuário. No caso dos ambientes hospitalares, este aspecto deve ser mais forte ainda, pois os espaços são projetados para receber pessoas geralmente em estágio de recuperação, onde o fator emocional muito influi. Sendo assim, o ambiente deve propiciar ao indivíduo, sensação de bem-estar e tranquilidade, o que, consequentemente, lhe proporcionará a sensação de segurança e confiabilidade.
Segundo SAMPAIO, em sua tese de doutorado, existem vários estudos que comprovam o beneficio de ambientes mais humanos na recuperação de pacientes, evidenciando por isso a importância da humanização:

...primeiramente o paciente é uma pessoa que pelas suas condições físicas e psicológicas tem as seguintes sensaç̃es expectativa ansiedade desconfiança inseguranç desânimo tristeza e medo Por estar na maior parte das vezes imóvel o seu sentido visual auc (a)

Seguindo a mesma linha de raciocínio, MEDEIROS diz em sua dissertação de mestrado em psicologia que "a humanização aparece como tentativa de resgate da condição de sujeito como ser integral e de uma nova concepção do processo saúde-doença, o que inclui a preocupação com os significados atribuídos ao adoecer." ${ }^{28}$ e inicia uma conceituação:

[...] a humanização hospitalar envolve - ou pelo menos deveria envolver - elementos relativos ao atendimento e ao espaço físico, estando entre os primeiros a relação estabelecida entre o profissional de saúde e os pacientes, e entre os segundos, a ambientação do edifício e o seu paisagismo.

Vejam-se os comentários feitos por pacientes, personagens do documentário de CROMBIE: "É uma ironia cruel que, justo quando nos sentimos mais vulneráveis, travamos contato com um dos tipos mais frios e duros de arquitetura..." (CROMBIE, 2008). "Os longos corredores em hospitais são muito assustadores para mim..." (CROMBIE, 2008). "Você se sente desorientando, não tem certeza de onde está..." (CROMBIE, 2008). Neles percebe-se que os ambientes hospitalares, em sua maioria, desmentem os aspectos mais objetivos deste conceito, isto é, "a teoria, na prática, é outra". E isso é algo que deve ser combatido, pois seus efeitos nos pacientes, se não são maléficos, também não cumprem seu papel, auxiliando na sua recuperação, conforme sugere novamente SAMPAIO: "Um ambiente hospitalar humano deve ser confortável, transmitir bemestar e propiciar um padrão satisfatório de qualidade para todos os seus usuários, sem exceção"30

Estas citaç̃oes de SAMPAIO e MEDEIROS e os comentários feitos no documentário de CROMBIE conduzem ao mesmo ponto de vista: a humanização tem papel importante na recuperação do paciente e mais, reforçam a idéia de que o termo humanização é o conceito que dá ao ambiente a garantia de que ele influenciará no ser humano que o utilizar, de maneira benéfica, aumentando, assim, suas condições de melhora.

Como cita MEDEIROS:

-ambientes com potencial terapêutico 'ou 'elementos de design que promovam saúde'. Tratam-se dos elementos presentes na própria organizaç̃ão espacial e ambientação do edificio que beneficiam o paciente durante a internaç̃o ou alsum tipo de procedimento realizado ${ }^{31}$ 


\subsection{Arquitetura para estabelecimentos assistenciais de saúde}

Que a arquitetura tem papel fundamental no sucesso ou não de um estabelecimento assistencial de saúde é fato, pois a arquitetura, porque constitui o processo que permite o planejamento de todo o complexo contexto, tem a capacidade de levantar, analisar e trabalhar as necessidades para cada edificação em questão. Através da arquitetura pode-se visualizar toda a problemática envolvida e equalizá-la a ponto de permitir a construção de ambientes adequados a cada situação.

Quando da discussão sobre "humanização" a arquitetura sempre tem que ser voltada para o ser humano e, no caso dos espaços assistenciais de saúde, ela tem maior importância ainda. pois ela se volta para o ser humano talvez em sua condiç̃a de maior sensibilidade, como coloca REMEN:

Segundo Remen (1993 apud MEDEIROS; LUCIANA DE, 2004, p. 33), saúde é o equilibrio das dimensões mente-corpo-sentimento e requer uma vida com qualidade, calor, amizade, proposito, humor e esperança. A ruptura desse equilibrio, aliado às escolhas e usos que são feitos do nosso corpo, afeta os três aspectos da pessoa e ocasiona a doença, seguida de dor e sofrimento próprios de cada um. Em oposição semelhante, Santos e Sebastiani (2001, p.150 apud MEDEIROS:LUCIANA DE, 2004, p. 33) apontam que é '( ) a desarmonia orgânica ou psíquica que, através de sua manifestacão, quebra a dinâmica de desenvolvimento do individuo como um ser global gerando desarmonizacão da pessor: compreende se esse desequil'brio como um abalo estrutural na condiç̃o do ser dentro da sua sociocultur ${ }^{32}$

A partir desta constatação, PINTO salienta que "O hospital como um todo tem como princípio básico a proteção ao paciente.." ${ }^{\prime 3}$. O hospital tem que ser e parecer seguro para dar ao paciente a sensação de confiança que ele precisa para se recuperar.

Segundo a RDC $50^{34}$, a definição de hospital é a seguinte:

Hospital - estabelecimento de saúde dotado de internação, meios diagnósticos e terapêuticos, com - objetivo de prestar assistência médica curativa e de reabilitacão, podendo dispor de ativida de

as, na verdade, hospital vai muito além dessa definição: hospital é o lugar que tem que oferecer ao paciente todas as condições necessárias para ele se tratar, se recuperar e retornar à sua vida normal o mais rapidamente possível. É muito mais que dar assistência programada por um período. Hospital é o espaço arquitetônico que visa além de atender às questões básicas necessárias - conforto ambiental, racionalização da circulação, segurança etc. -, permitir a melhor realizaç̃o dos procedimentos médicos e auxiliar na melhora da relação entre paciente equipe médica, infuenciando assim, de maneira benéfica, a recuperação do paciente. 0 conceito desses estabelecimentos vem evoluindo e a sua objetivação física vem buscando cada vez mais a eficiência funcional dos edifícios, conforme a citaç̃a de Lee:

De acordo com Lee (1977 apud MEDEIROS; LUCIANA DE, 2004, p. 56), os estudos sobre o impacto do ambiente físico do hospital no comportamento dos pacientes, revelaram meios de oferecer melhorias aos ambientes pouco atrativos, monótonos e sombrios, com repetições de elementos como portas janelas e desenhos de piso. Além disso, trouxeram à tona diferentes problemas da própria cultura médica e de estrutura ambiental do edificio que acabam desencadeando um funcionamento ultrapassado da instituição. ${ }^{36}$

Ainda tratando da mesma questão, temos a observação de SAMPAIO quanto à influência que o ambiente tem na qualidade do atendimento em vários aspectos:

O arquiteto pode colaborar para minimizar o desconforto destes ambientes, geralmente frios, impessoais com cheiros e rú́dos peculiares, pessoas sofrendo e profissionais agitados, projetando meios de descanso, tranquilidade, relaxamento, que permitam que o paciente se sinta mais confiante e que tenha condições de se recuperar mais rapidamente e por sua vez, que também propiciem à equipe de profissionais um local de trabalho que possibilite um atendimento de melhor qualidade, resultando em um maior rendimento, mais produtividade, segurança e, o mais importante, que este profissional desempenhe melhor a sua função, com satisfação. ${ }^{37}$

Entendendo desta maneira a importância da harmonia entre ambiente e os demais requisitos necessários para a recuperação do paciente, começa-se a traçar uma concepcão mais clara do papel da arquitetura nesses ambientes. TOLEDO foca esta questão de maneira bastante eloquente

.... ambiente hospitalar certamente pode ser um facilitador e mesmo um estimulador de práticas que considerem a auto-estima dos pacientes como um fator de cura. Nesse sentido, acreditamos que os arquitetos precisam posicionar-se como protagonistas desse processo, recusando o papel de meros coadjuvantes, cujo encargo seria apenas o de projetar ambientes definidos em programas hospitalares desenvolvidos, feitos, em sua maioria, sem sua participação.

Trata-se portanto de recuperar o papel e a responsabilidade de proporcionar, por meio da arquitetura, as condiç̃eses funcionais e de conforto necessárias ao bom desempenho das práticas médicas, bem como o bem-estar e a auto-estima dos usuarios dos edificios de saúde. Atuando assim, os arquitetos certamente contribuirão para o processo de cura dos pacientes. ${ }^{38}$

A partir de então, vislumbra-se uma ampla abrangência da prática em arquitetura, com ferramentas adequadas para se alcançar melhores resultados em termos de concepção de espaços hospitalares, como, por exemplo, em relação à questão do conforto térmico, conforme salienta FROTA e SCHIFFER:

${ }^{32}$ REMEN (1993 apud MEDEIROS, 2004, p. 33), ${ }^{33}$ PINTO (1996, p. 87) 
À arquitetura cabe tanto amenizar as sensaçõos de desconforto impostas por climas muitos rígidos, tais como os de excessivos calores frios ouventos, como também propiciar ambientes que sejam, no mínimo. tão confortáveis como os espaços ao ar livre em climas amenos. ${ }^{39}$

Também começa a ficar mais claro o quão complexa é a concepção de um ambiente assistencial de saúde pois "Pensar os espaços de um hospital é considerar até 120 tipos diferentes de atividades a serem realizadas ao mesmo tempo, 24 horas por dia, pelos mais diversos funcionários - [..] - sem se esquecer da circulação dos pacientes." (GEROLLA, 2007, p. 66).

Desta maneira, entende-se o porquê de KARMAN e PINTO salientarem a importância do projeto e do planejamento quando da concepção desses ambientes.

Segundo KARMAN:

A arquitetura, manutenção preditiva, arquitetura de manutenção ou manutenção orgânica origina-se. como as demais, na prancheta ou na tela do computador e destina-se a incorporar à futura instituição requisitos arquitetênicos construtivos, de instalação e de funcionamento, capazes de viabilizar. facilitar e tornar econômica racional sesura a futura manutenç̃o do hospital 40

A fase de pré-planejamento e de interplanejamento caracteriza-se pela disponibilidade e correto emprego de dados, informações, levantamentos, pesquisas, programa de necessidades, conhecimento do funcioname te utilização, particularidades e outros; neste contexto representa importante

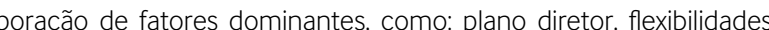
previsão de expansão, percursos, fluxos segregados e outros. ${ }^{41}$

Segundo PINTO, o planejamento também é importante, conforme se pode ver na citação seguinte:

O planejamento é essencial para a criação de um hospital ou de toda uma rede de unidades e a falta de um planejamento adequado tem sido a causa do surgimento desordenado de hospitais que não atendem às necessidades da populaç̃o a que se destinam. ou não têm possibilidade de serem conclúdos ou mantidoss

Complementando estes argumentos, SAMPAIO acrescenta mais variavéis à questão do planejamento como clima, topografia, insolação, condições ambientais etc, conforme vemos na citação seguinte:

O projeto de um ambiente hospitalar, mais do que qualquer outro tipo de projeto deve ser desenvolvido considerando-se: o clima onde ele será inserido, a insolação, a topografia local, as condições ambientais e paisagísticas; o programa com toda a sua complexidade e as diversas especialidades; a sua flexibilidade e expansibilidade: a seguranca: eficiência no desenvolvimento das atividades; adaptabilidade a novas descobertas e tecnologias e a satisfacãõo e bem-estar dos seus usuários. ${ }^{43}$
Através destes comentários, percebe-se a complexidade do assunto 'arquitetura' quando relacionado ao estabelecimento assistencial de saúde. Complexidade não somente conferida pelo complexo aparato técnico que envolve o funcionamento de uma instalação hospitalar, mas principalmente por se tratar de uma arquitetura que não pode dar-se o luxo de não relevar seu usuário, devendo, necessariamente, voltar-se para o paciente e assim assumir a responsabilidade de poder, ou não, ajudar na sua recuperação.

Nos exemplos práticos com os quais se deparou na bibliografia, em especial os de Lelé - João Filgueiras Lima - e Rino Levi, identificou-se uma série de requisitos, objetivos ou subjetivos, necessários para se atingir uma boa e eficiente arquitetura nesses edifícios. Tais requisitos, na verdade, são básicos e necessários para se atingir o sucesso em sua utilização. Eles impõem, ja nos termos de elaboração do programa, que a qualidade de seus atributos não faça diferenca entre segmentos do público que o utilizará - o que aparece, já de início, como fundamental para sua eficiência, isto é, seria como se se imaginasse, a par de uma perspectiva de atendimento universal à saúde, também um programa de necessidades arquitetônicas que se pautasse como uma "arquitetura universal". Mas, obviamente, quando se fala em requisitos mínimos e básicos, entende-se que estes precisam ser, por pressuposto, universais. Por outro lado, devem ser plurivalentes, isto é, passíveis de serem aproveitados para garantir a qualquer edificio sua eficiência. No caso dos hospitais, há outros itens a serem considerados, tais como serviços hotelaria, decoração, utilização de equipamentos atuais (TVs, ar condicionado, camas com controles eletônicos), etc, mas esses requisitos sequer são colocados em pauta por se tornarem supérfluos diante da importância do requisito de universalidade.

De modo geral, os principais requisitos básicos a serem tratados são: adequação do edifício ao local onde será implantado, tanto técnica quanto sócial e culturalmente falando; estudo funcional do problema quando da elaboraç̃ão do projeto; agrupamento de usos e atividades afins tanto para racionalizar o uso, quanto para minimizar custos; auxílio na prevenção à infecção hospitalar através de artifícios de projeto; racionalização das circulações; flexibilidade dos ambientes; preocupação com o conforto ambiental, através da iluminação natural e artificial, ventilação também natural e artificial, utilização de cores, som e água; presença do verde no ambientes, através do paisagismo, relação entre interior e exterior e humanização dos espaços.

Obviamente, há muitos outros requisitos que precisam e devem ser analisados, quando da elaboração dos projetos, mas estes, aqui relacionados, devem ser privilegiados, não somente porque funcionam como base para os demais, mas principalmente porque são requisitos que influenciam na qualidade do ambiente e consequentemente influenciam na qualidade oferecida aos usuários e aplicada na recuperação dos pacientes.

${ }^{39}$ FROTA (et al., 2003, p.53), ${ }^{40}$ FROTA (et al, 2003, p. 22)

${ }^{41}$ Ibidem, p. $54,{ }^{42}$ PINTO (1996, p. 154), ${ }^{43}$ SAMPAIO (2004, p. 154) 


\subsubsection{Requisitos Básicos}

\section{A - Adequação ao local}

Este é o primeiro requisito a ser atendido, até mesmo porque é o primeiro passo a ser dado quando a intenção é a construção de um espaço voltado para o atendimento de saúde, já que é pela escolha do terreno que devem ser iniciado os procedimentos de elaboração de projeto, conforme saliente BITTENCOURT:

Os critérios relativos ao clima, insolação, acessibilidade, entre outros fatores, devem determinar a escolha do local para a construção do edificio. l... E preciso que o espaço em que está situado o hospital esteja ajustado ao esquadrinhamento sanitário da cidade. É no interior da medicina do espaço urbano que deve ser calculada a localização do hospital [..., é preciso não somente calcular sua localização, mas a sua distribuição interna de seu espaço.

TOLEDO coloca muito claramente as preocupaç̃oes primordiais quando da implantação do estabelecimento assistencial de saúde, ressaltando a importância do planejamento rigoroso quanto à localização da edificação, bem como da importância da presença do arquiteto no processo, contribuindo com seus conhecimentos urbanísticos e de planejamento:

A escolha do local onde será implantado o hospital deve resultar de um esforço de planejamento, cujo principal objetivo é inserir, com sucesso a nova unidade na rede de saúde em funcionamento. Assim, para localizar onde o hospital será mais necessário, deve-se levantar e analisar, entre outros dados, a composição da população, o quadro nosológico, e a oferta de leitos e serviços e os respectivos déficits existentes.

A formaç̃a urbanística do arquiteto é preciosa neste momento, tanto para a espacializaç̃ão da rede quanto para a seleção e a escolha final dos terrenos onde serão erguidos os hospitais. Com o apoio do arquiteto, poderão ser evitados diversos problemas, entre os quais eventuais conflitos com as tendências de expansão da cidade ou com a proximidade de usos incompatíveis com a função hospitalar (cemitérios, aterros sanitários, fábricas etc.

A presença do arquiteto contribui ainda para evitar que a unidade hospitalar seja construída em loca sem infra-estrutura ou em terrenos com área inferior à necessária para futuras expansões. A avaliação da topografia, das características do solo, do recobrimento vegetal existente, da insolação, dos ventos dominantes e das condições de acessibilidade são, entre outros aspectos, pontos a serem considerados pelo arquiteto na escolha do terreno. ${ }^{45}$

Independentemente dos requisitos específicos dos estabelecimentos assistenciais de saúde a serem atendidos, o respeito às normas municipais e à legislação local precisam também ser respeitadas - tais como análise da adequação ao plano diretor etc. Porém, o que precisa ficar claro é que somente $o$ atendimento a estas normas não é suficiente para garantir uma adequaç̃o eficiente ao local, pois estas tratam muito mais das questões de gabarito, área construída, recuos etc., do que da preocupação com a obtenção da qualidade em si. Já as normas relacionadas à ANVISA (Agência Nacional de Vigilância Sanitária) são mais específicas e realmente buscam maior qualidade dos ambientes. Estas, porém, serão objeto de discussão específica.

Infelizmente, a realidade nos mostra que esta preocupação com a adequação ao local não é tratada como 'condição necessária' e efetivamente pouco acontece na prática, como comenta PINTO:

É muito comum uma instituição ou grupo de profissionais pretender a implantação de um hospital em determinada comunidade com um número de leitos preestabelecidos sem que, no entanto, tenha sido realizado qualquer estudo ou levantamento referente àquela localidade, de modo que venha justificar implantação daqueles leitos e até mesmo, de necessidade daquela unidade. ${ }^{46}$

A adequação do estabelecimento de saúde ao local não deve somente obedecer a critérios específicos de implantação, como topografia, dimensionamento etc., mas também considerar todo o seu entorno, em harmonia com a infra-estrutura existente no local. Por exemplo: a rede de serviços existente (infra-estrutura, transportes, abastecimento etc.), os aspectos sócioeconômicos, a dotação de equipamentos públicos em geral, acessibilidade, entre outros. Uma unidade hospitalar, ao ser implantada, deve estar perfeitamente integrada à rede de serviços de sua região, conforme coloca PINTO:

Assim, antes de se desenvolver qualquer empreendimento voltado para a implantacăo de leitos. É necessário que sejam realizados estudos de diagnóstico relacionados aos diversos aspectos do planejamento em saúde como a estrutura demográfica a configuracão migratória os aspectos socioeconômicos, geográficos, epidemiológicos e outros, que devem ser analisados com o objetivo de se

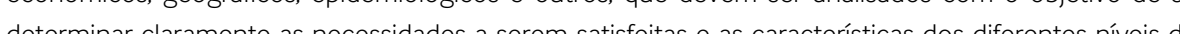
complexidade dos senicos a serem prestados 47

É necessário, também, identificar o que existe na região em termos de suporte médico, atendimento à saúde etc., tanto nos aspectos quantitativos como nos qualitativos, pois é importante uma perfeita adequação à realidade dos serviços instalados para se evitar conflitos e superposições desnecessárias - o que pode colocar em risco a viabilidade tanto do empreendimento em instalação quanto dos já instalados. Novamente, auxiliados pelas consideracõos de PINTO:

imprescindivel o conhecimento das condiç̃es médico-sociais da área de abrangência da unidade pretendida, observando-se o tipo de assistência nas unidades já existentes, os equipamentos médicos disponíveis nessas unidades, o pessoal qualificado para o seu funcionamento e os diversos órgãos assistenciais destinados ao atendimento de sua população ${ }^{48}$ 
Importante salientar que não só a integração do estabelecimento ao local é importante: quando possível, é recomendado que o próprio terreno a ser escolhido seja cuidadosamente avaliado antes da definição do empreendimento, pois é fato que a escolha acertada do terreno em muito contribui com a possibilidade de o empreendimento agregar eficiência. PINTO esclarece na citação a seguir:

O planejamento das unidades de saúde começa muito antes dos estudos para a edificação propriamente dita. Inicia-se na própria escolha do terreno, onde a observaçăo do seu entorno e primordial para uma localização adequada. Problemas de sujeira, insetos, ruídos, poeira, proximidade de terrenos alagados, rios polúídos, etc, são aspectos negativos que podem concorrer para aumentar os riscos de contaminação dentro dos hospitais. ${ }^{49}$

A escolha do local para implantação de uma unidade de saúde, notadamente quando envolve o leito hospitalar, terá importância fundamental em seu planejamento e funcionamento futuro. Um pequeno engano no planejamento ou na construção pode, muitas vezes, ser contornado, porém um erro de seleção do terreno não pode ser corrigido após a conclusão da obra. Assim sendo, deverão ser observadas questões relacionadas à topografia, tipo de solo, drenagem, movimento de terra e à orientaç̃o do edifício. 0 conhecimento especializado dessas questões resultará em grande economia para a construção.

ROSENFIELD, embora tenha escrito seu livro "Hospital: Integrated Design" em 1950, coloca ponderações que nos dias atuais são bastante pertinentes, no que ser refere à realidade dos estabelecimentos assistenciais de saúde. E, com sua maneira bastante simples e didática, apresenta insumos que podem resumir tudo que se colocou até o momento, relativamente ao assunto, conforme mostram as citações a seguir:

A razão para consultar um arquiteto (e até mesmo, quando indicado, o administrador também) antes de escolher o local onde o prédio será construído é simplesmente porque ele the garante sugestões e conselhos profissionais num passo basicamente importante.

A consideração mais importante na escolha da localização urbanística para o hospital é ter um terreno convenientemente suportado pelos mais baratos e mais acessiveis meios de transporte. Hospitais devem ser acessivivis não somente por pacientes, mas também por médicos, enfermeiros, visitantes, suprimentos. bombeiros etc. ${ }^{52}$

Além de todos esses aspectos, vale ressaltar também que a perfeita adequação do estabelecimento ao local, permite o máximo aproveitamento de suas condições de conforto ambiental, o que é fundamental para o funcionamento do estabelecimento. Porém, ta aspecto será novamente abordado quando da análise dos requisitos ligados à preocupação com o conforto ambiental.

\section{${ }^{49}$ PINTO (1996, p. 109)}

${ }^{5}{ }^{5}$ I bidem, p. 45

${ }_{52}$ ROSENFELL (1950, p.30)

22 PINTO (1996, p.109)

\section{B - O Projeto deve resultar de um estudo funcional e técnico do problema}

Um estudo funcional e técnico do problema significa entender que vocação se espera de um determinado projeto, estabelecida essa vocação a partir do diálogo com profissionais da área de saúde (médicos e administradores), considerados como integrantes da equipe de desenvolvimento.

Por exemplo, quando é projetado um hospital pediátrico, o estudo funcional e técnico é bastante diferente do estudo funcional de um hospital de tratamento de câncer. É a partir deste raciocínio que trabalharam Lelé, no desenvolvimento dos projetos da Rede Sarah, e Rino Levi, em todos os projetos hospitalares que desenvolveu. Sempre analisaram a questão em profundidade, tendo aos seus lados profissionais da área de saúde, adequados conforme as demandas de cada situação.

O expediente de se envolver no desenvolvimento do projeto dos ambientes assistenciais de saúde uma equipe multidisciplinar torna-se fundamental, conforme comenta TOLEDO:

Com efeito, tal prática possibilita a troca permanente de saberes entre os profissionais de saúde e os demais colaboradores, entre os quais arquitetos e designer, cuja contribuição tem sido fundamental equipamentos médicos utilizados pela Rede ${ }^{53}$

Lelé é o melhor exemplo de que, na prática, este procedimento torna-se uma receita de eficiência, sucesso do empreendimento e sua consequente transformação em referência. Mais que isso, uma análise expedita dos hospitais da Rede Sarah, de Lelé, embora todos eles tenham a mesma função - ortopedia - nos faz perceber que as unidades são bem diferentes umas das outras, pois cada situação de implantação requer um cuidado diferente. Esta singularidade que se verifica nas situaç̃̃es de implantação e nas características arquitetônicas resulta da equilibrada simbiose entre a preocupação com a adequação ao local - principalmente com relação ao conforto ambiental - e o estudo funcional e técnico do problema.

Jarbas Karman é bastante objetivo nesta questão, como se pode ver nas citaç̃̃es a seguir, onde ele defende a importância do planejamento, de levantamentos, de pesquisas e também um trabalho em conjunto com outros profissionais, formando uma equipe multidisciplinar resumindo, de maneira bastante objetiva, o que deve acontecer com o projeto de uma unidade assistencial de saúde: "É a conscientização da concepção: 'Faça certo da primeira vez', de Eduard Demming". ${ }^{54}$ 
A fase de pré-planejamento e de interplanejamento caracteriza-se pela disponibilidade e correto emprego de dados, informaç̃es, levantamentos, pesquisas, programa de necessidades, conhecimento do funcionamento e de utilização, particularidades e outros; neste contexto representa importante previsão de expansão, percursos, fluxos segregados e outros. . $^{5}$

O físico encontra-se intimamente vinculado ao funcional; o planej mento arquitetônico, ao administrativo. Arquitetura hospitalar, engenharia de manutenção, bioengenharia, engenharia clínica, informática, engenharia hospitalar, organizaç̃ão e administração hospitalar são meios, procedimentos e recursos que, juntamente com as atividades dos profissionais de saúde, visam viabilizar o objetivo comum: proteção, promoção e recuperação da saúde. ${ }^{.6}$

Da mesma forma, TOLEDO coloca a importância do planejamento desses edifícios, quando afirma ser "... elaboração do Plano Diretor Hospitalar, ferramenta imprescindível para a preservação da racionalidade e da funcionalidade do projeto original"57.

\section{C- Racionalização das circulações e agrupamento de usos e atividades afins}

Este quesito nada mais é que a preocupação com a racionalização do projeto como um todo. Em termos objetivos, se o problema das circulações é solucionado e se a distribuição e articulação dos ambientes assumem um agrupamento racional de usos, o projeto é todo racional.

Por agrupamento de usos, entende-se a organização funcional dos ambientes dentro do edifício de maneira que se tenha uma distribuição lógica e funcional, garantindo maior eficiência aos procedimentos, segurança, agilidade, economia e ainda contribua na prevenção à infecção hospitalar. Por exemplo, devem-se agrupar setores de procedimentos, tais como cirurgias, exames etc. Do mesmo modo, outros ambientes, como as áreas de permanência e recuperação de pacientes, devem estar agrupados de outra maneira, como por exemplo, áreas dos edifícios destinadas exclusivamente à internação, enquanto que o setor de emergência, de outra, privilegiando os acessos tanto de entrada de emergência quanto de acesso ao centro cirúrgico ou centro radiológico, por exemplo, e assim sucessivamente. Não é uma tarefa fácil fazer um agrupamento de usos eficiente e funcional, mas é vital para uma perfeita adequação do empreendimento.

De forma análoga, a racionalização das circulações deve ser criteriosamente buscada. Intimamente ligada ao agrupamento eficiente de usos, será esta circulação racional que garantirá uma perfeita harmonia e funcionalidade dos setores. As circulações podem ser divididas em: circulação restrita, de funcionários, de usuários, de material contaminado etc., tudo de maneira a permitir um perfeito e eficiente funcionamento do empreendimento, como coloca SAN JUAN: contribuição a observância e incorporação de fatores dominantes, como: plano diretor, flexibilidades

Um aspecto muito característico dos hospitais é a variedade de usuários presentes e suas diferentes necessidades ou expectativas, fato que pode ocasionar conflitos na forma de subgrupo (pacientes funcionários e visitantes) lidar com o espaço físico. ${ }^{58}$

Na atenção a este requisito, como mostram ANELLI, GUERRA \& KON na obra referente a Rino Levi, os projetos hospitalares elaborados por ele, se não são exemplos de eficiência, são exemplos da necessária preocupação com ela. Rino Levi elaborava desenhos da volumetria dos projetos hospitalares e através deles resolvia de maneira racional todo o agrupamento de usos e a circulação racional no edifício.

Desta maneira, pode-se entender claramente que $\mathrm{O}$ atendimento a estes requisitos é fundamental na questão da prevenção das infecções hospitalares e o projeto, adquirindo os atributos de racionalidade e eficiência nos usos dos ambientes, certamente obter-se-á um bom percentual de garantia deste controle.

\section{D - Auxílio na prevenção à infecção hospitalar}

"Segurança todo o hospital deve oferecer não só aos seus pacientes mas, também, aos funcionários que aí trabalham, contra possíveis fontes de infecção..."59

Partindo-se, então, do princípio que o arquiteto projetista tem fundamental responsabilidade no auxílio a prevenção da infecção hospitalar quando de sua atuação na realização do projeto - racionalizando circulações e agrupando usos de modo também racional - resta salientar alguns outros pontos importantes, dentre os inúmeros existentes, conforme ressaltam os autores pesquisados.

Obviamente, serão mencionados aqui os recursos de prevencão à infeccão, mas somente aqueles mais voltados para a questão física do edifício. Não caberia colocar a questão a partir, por exemplo, do modo como se realizam procedimentos etc., uma vez que não seria competência de um trabalho que trata do papel da arquitetura na humanização de ambientes hospitalares. Contudo, é importante ressaltar que são os procedimentos que orientam os fluxos e a distribuição de ambientes. Tal situação fica clara na citação de FIGUEIREDO:

Como a orientação para projetos de salas cirúrgicas, enfatizando a prevenção contra a infecção hospitala FIGUEIREDO (2001 apud SAMPAIO, ANA VIRGINIACARVALHÃES DE FARIA. p. 183) recomenda a divis̃̃o do

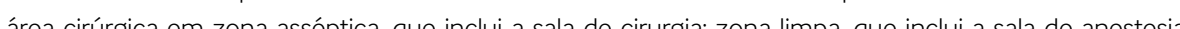
e área de escovacão e zona de protecão incluindo a área de entrada. a sal de recuperaç̃o e outas e area de esconaço e zona dicto

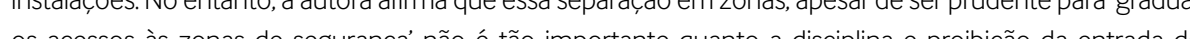
centrada de pessoas estranhas às áreas limpas. Quanto à separação dos corredores da entrada e sád́a, não é um ponto 
relevante no controle da infecção, e as bactérias da equipe médica, dos pacientes e dos equipamentos devem preocupar mais nas infecções pós-operatórias do que as bactérias carregadas em carrinhos ou macas. Portanto, a maior fonte de contaminação durante uma cirurgia é proveniente da equipe médica e as bactérias dispersas na pele são de maior importância do que as de trato respiratório. Portas fechadas durante um procedimento cirúrgico e a ventilação como pressão positiva sobre a mesa cirúrgica são maneiras eficientes ara evitar a infecção vinda de outras partes da sala e de outras salas contíguas. ${ }^{60}$

Quando se fala na prevenção à infecção hospitalar relativamente ao planejamento, PINTO salienta:

Uma vez definidos a escolha do terreno e os aspectos gerais de planejamento urbano, cabe apresentar soluções arquitetônicas capazes de oferecer à equipe de saúde as facilidades necessárias às suas atividades em ambientes adequados com áreas compatíveis e condiç̄oes físicas que venham contribuir para a redução do risco de infeccão.

Como se sabe, a luz natural, solar, é uma das melhores fontes de prevenção à infecção hospitalar. Tratar-se-á deste assunto mais à frente, na parte de conforto ambiental. No entanto, comprovadamente, a prevenção à infecção hospitalar é uma das mais importantes funç̃oes da luz natural, sobre o que se tem a formulação de ROSENFIEL: no sentido mais exato do desenho do hospital, a boa luz natural é importante para os hospitais por três razões: é apropriada à visão, tem efeito psicológico e protege contra infecção.

Ainda há alguns pontos a serem ressaltados quando se refere às fontes de infeccão hospitalar. Pinto salienta: "É sabido, por dados comprovados em estatísticas internacionais, que as áreas do hospital que apresentam maior índice de contaminação e infecções cruzadas são a Lavanderia e a Central de Material e Esterilização..." ${ }^{\text {é2 }}$ MONTERO salienta a preocupação de Lelé com o sistema de ar condicionado:

0 ar condicionado é o grande veiculo das bactérias, tornando imprescindivel a manutenção de todos os dispositivos dos sistemas de ar condicionado. O novo hospital Sarah Rio de Janeiro prevê esse aspecto. Os dutos de ar condicionado, "de insuflamento", correm livres por cima da viga. Os dutos podem ser abertos para limpeza. Possuem uma tampa em cima, para sua manutencãa periódica. ${ }^{63}$

Vale colocar ainda que a dificuldade na prevenção à infecção hospitalar, embora seja assunto de corriqueira abordagem por parte dos Estabelecimentos Assistenciais de Saúde - EAS, ainda enfrenta obstáculos a serem superados, conforme colocam Fiorentini, Lima e Karman no texto Arquitetura na Prevenção de Infecção Hospitalar:

A arquitetura-Infecto-Preditiva, em sua luta por hospitais mais seguros, defronta-se com preconceitos tabus, costumes e tradições arraigados, nem sempre lastreados em suportes científicos, como hospitais pactuando com: salas de cirurgia séptica; bloco cirúrgico de corredor duplo; elevadores e monta-cargas privativos para transporte de material sujo; elevadores e monta-cargas privativos para transporte de

${ }^{0}$ FIGUEREEDO (http://www.bibliomed.com.br. Acesso em outubro de 200

61 PINTO (1996, p. 109)

63 lbidem, p.87)

ONTERO (2006. . 156) material sujo; autoclaves verticais; ar condicionado de janela em áreas assépticas; repúdio a tubulão de descida de roupa suja e de resíduos sólidos; indiferença com relação a refluxo de ralos e a ocorrência de pressão negativa em rede de água potável, descaso com manutenção preventiva e aferição de manômetros e termômetros em equipamentos de esterilização: utilização de óxido de etileno sem 0 necessário conhecimento de causa: indevido uso e instalação de sistema de aspiração e outros. ${ }^{64}$

\section{E- Flexibilidade dos ambientes}

Evolução: é um conceito real que está intimamente ligado à questão da flexibilidade pois é a flexibilidade do objeto arquitetônico que possibilita sua evolução, sem limitá-la. Este raciocínio, principalmente quando ligado às questões práticas dos edifícios, torna-se fundamental. "As mudanças na sociedade e na medicina moderna progridem numa velocidade tal, que tornam as soluções de hoje inapropriadas para os problemas de amanhã.”.65

A constante evolução das técnicas e equipamentos hospitalares faz com que a construção física do ambiente permita alteraç̃oes conforme a evolução. 0 ambiente não pode limitar a evolução e a eficiência dos tratamentos e procedimentos, como salienta PINTO:

Considerando essas rápidas mudanças, tanto sob o ponto de vista tecnológico como gerencial, podemo observar que o planejamento de uma unidade hospitalar abrange uma vasta gama de atividades. das mais simples às mais complexas, de aspectos imediatos e a de longo prazo, o que implica no desenvolvimento de técricas construtivas adequadas. 0 importante é voltar o planejamento da unidade para adaptaçōes futuras, de tal modo que a mesma não venha a perder a sua identidade, tanto sob o aspecto organizacional como funcional. ${ }^{60}$

Essa capacidade de permitir a adequação do edifício de acordo com o desenvolvimento tecnológico e a evolução dos procedimentos médicos está nas mãos do arquiteto, segundo comenta TOLEDO:

As transformaç̃ões que ocorrem no edificio hospitalar a partir de usa inauguração decorren principalmente, do desenvolvimento tecnologico de que resulta um processo cada vez mais acelerado de incorporação de novas práticas e equipamentos médicos nos hospitais, exigindo constantes adaptações do edificio hospitalar. Ao arquiteto, portando cabe projetar uma edificação que possa suportar essas transformaçōes, sem abandonar o partido originalmente adotado e, principalmente, sem grandes transtornos para os usuários. ${ }^{67}$

Tal característica obtém-se com a utilização de instalações racionais, divisórias móveis, etc. A flexibilidade é fundamental pois, seus elementos arquitetônicos devem possibilitar adaptações para que a qualidade seja uma meta permanente. Além disso, pode-se dizer que um moderno hospital vive em obras desde a sua inauguração, consagrando-se como um voraz consumidor de áreas. A reserva, portanto, de grandes espaços para ampliação constitui-se praticamente como uma imposição.

\footnotetext{
${ }_{65}^{64}$ BRASIL (1995, p. 09) PINTO (1996, p. 42) ${ }^{67}$ TOLEDO (2007, p. 445)
} 
Como coloca KARMAN, mudanças num estabelecimento assistencial de saúde são inevitáveis:

Mudancas e progressos são constantes, contínuos e infindáveis; novos equipamentos e instalações, de progressivo custo, precisão, tecnicidade e sofisticação demandam crescentes conhecimentos e cuidados, acompanhamento, dedicação, organização, disciplina e responsabilidade. ${ }^{68}$

O requisito de flexibilidade dos ambientes tem realmente a função de permitir a evolução das técnicas, dos equipamentos e da adaptação da construção a todas as novidades que vão surgindo, mas o que não pode deixar de ser salientado é que estas adequações constantes devem gerar, principalmente no caso dos estabelecimentos assistenciais de saúde, o menor incômodo possível, em função de seu principal usuário, o paciente. "Os problemas relacionados com as modificações de uma unidade hospitalar já construída, reduzir-se-ão enormemente se o projeto dessa unidade permitir adaptações às novas funções. (...) Para isso duas condições são primordiais: flexibilidade e durabilidade.... 69

Alguns estudos sistemáticos e muito sérios na Inglaterra questionam a questão da flexibilidade em hospitais, mas o fato é que no Brasil, tal requisito dever ser colocado de maneira que, se não existir pode colocar o funcionamento de muitos estabelecimentos em xeque, inclusive pela falta de recursos financeiros que obrigam a fazer adaptações nos prédios existentes ao invés de investir em novas construções, como colocam os estudos na Inglaterra.

Nos estudos práticos, verificar-se-á que esta questão é pertinente, conforme defende Lelé (João Filgueiras Lima) na citação de TOLEDO:

[.] quase tudo que havia projetado há 30 anos atrás, estaria hoje completamente obsoleto se, naquela época, tivesse adotado um partido fechado, que não tivesse as condiçỗes de flexibilidade necessárias para suportar a permanente evolução das práticas médicas que ali ocorreram desde 1970. ${ }^{70}$

\section{F - Preocupações com o conforto ambiental}

Para CORBELLA \& YANNAS (2003, apud ANA VIRGINIA CARVALHÃES DE FARIA, 2004, p. 155), uma pessoa está confortável quando observa ou sente um acontecimento ou fenômeno sem preocupaç̃o. incômodo, ou, quando está em um ambiente físico sentindo neutralidade com relação á ele. ${ }^{71}$

É exatamente esta sensação que deve ser buscada principalmente nos ambientes assistenciais de saúde: ela está envolvida na recuperação do paciente e é papel da arquitetura garantir essa condição. "Conforto ambiental, de acordo com KOENIGSBERGER et al. (1977 apud SAMPAIO, ANA VIRGINIA CARVALHÃES DE FARIA, 2004, p. 154), é a sensação de bem-estar completo, físico e mental, criada por um arquiteto no ato de projetar." Como salientam também FROTA e SCHIFFER:

68 KARMAN (1994, p. 14)

${ }^{69}$ PINTO (1996, p. 42)

71 SAMPAIO (2004, P. 155)
À arquitetura cabe, tanto amenizar as sensações de desconforto impostas por climas muitos rígidos, tais como os de excessivos calor frio ou ventos como também propiciar ambientes que sejam, no mínimo, tão confortáveis como os espacos ao ar livre em climas amenos ${ }^{72}$

De acordo com SAMPAIO (2004) considera-se 'qualidade' como sendo a sensação de conforto e bem-estar do usuário do ambiente construído, isto é, a sensação de ele sentir-se bem em um ambiente hospitalar, sendo um usurário ou sendo um paciente, um acompanhante, um médico, um visitante, um enfermeiro ou um funcionário.

FROTA e SCHIFFER ressaltam ainda que, quando a relação entre arquitetura e os requisitos de conforto ambiental encontram equacionamento eficiente, tal benefício ainda pode trazer economia na manutenção do edifício quando em funcionamento. Por exemplo, quando os diferenciais de temperatura interna e externa ao edifício proporcionam menor consumo de energia, também será demandado menor esforço dos equipamentos de refrigeração ou aquecimento para se equilibrar tais diferenciais:

A arquitetura, nas regiões de clima predominantemente quente, deve, segundo FROTA \& SHIFFER (1995 apud SAMPAIO, ANA VIRGINIA CARVALHÃES DE FARIA, 2004, p. 156) minimizar as diferenças entre temperaturas externas e internas do ar. Mesmo em locais com condições climáticas muito rígidas, propostas que valorizem o desempenho térmico natural podem ajudar a reduzir a potência dos equipamentos de refrigeração ou aquecimento, pois será menor a quantidade de calor retirada ou fornecida ao ambiente, beneficiando o edifício no consumo e na eficiência energética.

Importante ressaltar que, para se adquirir uma condiç̃ão de conforto ambiental minimamente adequada, alguns recursos precisam ser considerados na produção do edifício para que juntos respondam às demandas pelo conforto ambiental. Embora sejam vários, serão comentados, a seguir, apenas os aspectos da ventilação natural e artificial, de iluminação natural e artificial, do tratamento acústico e referentes à utilização de cores, reunidos no que se denomina "conforto térmico" e "conforto visual",

Há muitos outros fatores que influenciam esta questão, tais como a utilização de vegetacão da água, a relação entre interior e exterior do edifício, mas tais condições serão consideradas mais adiante, separadamente.

\section{F1 - Conforto Térmico:}

Segundo SAMPAIO, conforto térmico é o conforto ambiental que abrange as sensações de bem-estar em relação à temperatura, umidade relativa e movimento do ar, radiaccão solar e radiação infravermelha, emitida pelo entorno. Ou ainda, segundo a ASHRAE (American Society 
of Healting, Refrigerating, Air-conditioning Engenieers), conforto térmico é definido como: Um estado de Espírito que reflete a satisfação com o meio ambiente térmico que envolve a pessoa. ${ }^{74}$

Sabe-se que atualmente é fácil garantir a sensação de conforto térmico através do uso de materiais de controle, como peles de vidro refletivas para regular a entrada dos raios solares no ambiente, equipamentos de ar condicionado para controlar a temperatura interna, entre outros meios. Sabe-se que tanto a ventilação artificial quanto o controle de temperatura artificial são ferramentas que estão disponíveis para serem utilizadas. 0 que acontece, em geral, é uma utilização equivocada dessa tecnologia.

Enquanto estes aparatos tecnológicos artificiais deveriam trabalhar em harmonia com os recursos técnicos naturais para suprir uma necessidade mais específica, atualmente elessão muito utilizados como solução de problemas do conforto que a arquitetura não resolveu eficientemente. Isto é e abusando um pouco da analogia -, a utilização de equipamentos mecânicos e eletrônicos para assegurar algum conforto térmico tem sido mais curativa que preditiva. Mais, a arquitetura muitas vezes deixa de lado a preocupação com o conforto térmico no interior do edifício exatamente por saber que há mecanismos técnicos para atender a tais demandas. Isso é um erro conceitual que gera problemas sérios, principalmente nos estabelecimentos assistenciais de saúde, como, por exemplo, um alto custo de energia para manter aquecedores ou refrigeradores ligados, problemas com a proliferação de agentes de infecção hospitalar pelo sistema de ar condicionado - que, inclusive tem um alto custo de manutenção em função da sua necessária assepsia - etc. E, assim, mais e mais problemas vão surgindo.

No caso da ventilação forçada ou artificial, ela tem papel muito mais eficiente quanto utilizada em conjunto com a natural. Em situacões de extrema necessidade, ela pode ajudar no equilíbrio da temperatura, em situações onde, por exemplo, são necessários controles de temperatura e umidade, como centro cirúrgicos, UTIs etc. Sua utilização é sempre recomendável, mas tudo sempre dentro de certo bom senso, parametrizado pelo conhecimento que o arquiteto projetista deve adquirir para enfrentar a concepção de um espaço deste gênero.

Ventilação natural: a sua utilização é bem vinda nos casos dos ambientes hospitalares, sempre lembrando que ela pode influenciar muito na recuperação do paciente. Pessoas gostam de ar fresco e luz natural, mesmo quando a reação emocional não é tão importante (ROSENFIELD, p. 284). "A ventilação natural proporciona conforto através da renovação do ar do ambiente, sendo de grande importância para a higiene em geral e para o conforto térmico de verão em regiões de clima temperado e de clima quente e úmido."75

\section{F2 - Conforto Visual}

Segundo SAMPAIO, a definição de conforto visual, lúmico ou luminoso, é: conforto ambienta que se refere ao bem-estar com relação a ver bem, a ter uma quantidade de luz satisfatória que possibilite a realização de uma tarefa visual confortavelmente.

Obviamente, quando se fala em conforto luminoso, fala-se não somente de iluminação natura e artificial, mas também de cores, que são, na verdade, resultados da incidência da luz nos diversos elementos, como paredes, forro, móveis etc.

Para ser mais bem entendida a questão da iluminação, é fundamental entender sua evolução para que certas colocações e os seus porquês fiquem claros pois a iluminação, tanto natural quanto artificial, exerce fundamental influência na qualidade dos ambientes, desde o início da história dos ambientes assistenciais de saúde.

Quando se fala em iluminação natural, observa-se que nem sempre os estabelecimentos assistenciais de saúde tiveram a preocupação de hoje com tais recursos. Demorou-se concluir que a luz natural, dentro do ambiente, trazia benefícios.

Na Idade Média, por exemplo, as enfermarias eram controladas pela igreja e sua concepção seguia a das catedrais góticas: pequenas aberturas, que pouco iluminavam o ambiente. Mais ainda: impunham, pelo jogo claro/escuro, um ar dramático ao ambiente, o que, certamente, era prejudicial aos pacientes, não só psicologicamente, como também pela falta de salubridade. 0 conceito dos edifícios de saúde era bem diferente do atual: as enfermarias eram consideradas depósitos de doentes, não tinham o objetivo de curar o paciente e sim de tratá-lo até a morte. Por isso, eram conhecidas como "salle de mourir", pois dificilmente alguém retornava desses lugares. Analisando-se, ainda hoje há resquícios dessa concepcão, pois as pessoas mais velhas têm medo de frequentar hospitais, tendo em mente, inconscientemente, que vão para o hospital para morrer

Tal concepção começou a mudar quando o controle de tais edifícios passou da igreja para o mundo secular. Aparecem os corredores como forma de circulação, dividindo os ambientes e promovendo a separação dos pacientes por sexo e patologia, surgindo também alguma preocupação com o conforto deles - o que pode ser percebido pela utilização de dutos, lareiras e iluminação com queima de óleos. Ainda que não seja a situação ideal - pelos conceitos atuais -, percebe-se uma grande mudança na sua concepção.

75 FROTA S SCHIFFERR (2003, p. 124) 
No século XIX, já se vê, em alguns hospitais, a preocupação com as janelas para iluminar e ventilar internamente os ambientes. "A importância da ventilação e da insolação se propagou, arejando e higienizando os interiores". ${ }^{76}$ Conforme coloca LAMB:

LAMB (2000 apud SAMPAIO, ANA VIRGINIACARVALHÃES DE FARIA, p. 186) comenta que as janelas são aconselháveis nas salas de recuperação, não só pela luz natural funcionar como um estímulo aos pacientes mas principalmente, comenta a autor para o conforto dos funcionar cos e para evitar o estresse. pela permanência continuada em um ambiente fechado. ${ }^{77}$

Pasteur iniciou uma série de pesquisas que resultaram na modificação das concepções sanitárias em relação ao ar interior. A luz natural continuava tendo sua importância, principalmente por dar ao paciente a noção de tempo, para se orientar e proporcionar a sensação de liberdade, pelo contato com o meio externo. Mas a luz e o calor do sol, que controlavam a umidade e a proliferação de microorganismos, nem sempre eram desejados.

Na década de 50 do século XX, apareceram os estudos de elementos de controle da luz solar, objetivando iluminar as áreas mais profundas e reduzir o excesso de luz próximo à janela, garantindo qualidade de iluminação para os pacientes em ambos os locais. Segundo SAMPAIO:

Várias doenças e desajustes psicológicos são relacionados com a ausência de luz. Arquitetos, projetando adequadamente janelas para a iluminação de ambientes, podem contribuir com o aumento da produtividade e a saúde psicológica de seus ocupantes. ${ }^{7}$

Portanto, atualmente, projetar utilizando a iluminação natural, requer conhecimento e técnica, conforme se pode observar.

É importante também prever uma distribuicãão homogênea de luz no ambiente preocupando-se, na elaboração do projeto, com a localização, a orientação , o tipo, o tamanho e a forma geometrica das aberturas, o tipo e a cor dos vidros que serão utilizados, as cores que serão usadas nos caixilhos, nas superficies internas como teto, paredes e piso nas superfíicies externas, como muros, piso e construçōes adjacentes, lembrando sempre que as cores claras refletem mais e difundem melhor a luz que as cores escuras, além de absorverem mais, diminuindo assim a quantidade de calor que será emitido por essas superfícies escuras para o meio-ambiente. Não devemos esquecer ainda as características formais do local a ser iluminado como a relação comprimento e largura e altura do pé dirito que interferião do quantidade de luz disponive Para projer quantidace de luz disponive. Para proftar luva celeste e entorno

As principais vantagens da iluminação natural sobre a artificial são: quantidade de luz: comunicação interior/exterior; conservacão de energia; benefício físico e psicológico; desejo de ter luz natural e sol em um ambiente construído. ${ }^{80}$

${ }_{77}^{76} \operatorname{COSTI}(2002$, p. 59

77 LAMB (2000)

78 SAMPAIO (2004, p. 187)

${ }^{79}$ Ibidem, p. 160 ROBBNS (1986 apud SAMPAIO . 161 )
Com a revolução industrial, uma grande mudança ocorreu nos edifícios em geral, com a utilização da lâmpada elétrica.

Dentre as grandes vantagens que ela trouxe, podemos destacar:

- Eliminação de poluiç̃o no ambiente: a lâmpada elétrica deixa de poluir o ambiente, pois se elimina a geração de luz a partir de queima de óleos;

- Complementação da iluminação natural: permite uma melhor utilização dos espaços nos quais a luz natural não chega com a devida intensidade;

- Possibilidade de tarefas ininterruptas: com a utilização da lâmpada elétrica, tarefas antes feitas somente durante o dia, começaram a poder ser realizadas também durante a noite, como, por exemplo, cirurgias e atendimentos de emergência, reduzindo a morbidade e aumentando obviamente a qualidade do atendimento ao paciente.

Tais conceitos vêm ao encontro ao comentário de VIANNA \& GONÇALVES:

É importante lembrar que a iluminação artificial deve complementar a iluminação natural, sendo utilizada nos casos em que ela for realmente necessária, lembrando-se que juntamente com ela existe um interior do ambiente interferindo no conforto térmico também ${ }^{81}$

Além da lâmpada elétrica, os equipamentos elétricos necessários e úteis aos procedimentos médicos também se proliferaram, como não poderia deixar de ser. Em meados do século XX, os edifícios de saúde já se tornavam grandes consumidores de energia elétrica.

A descoberta da lâmpada fluorescente veio trazer alguns benefícios à iluminação artificial

- Permite o mesmo nível de iluminação com um consumo menor de energia elétrica.

- É uma iluminação mais fria.

- Em função de seu formato tubular, permite uma melhor distribuição da luz.

- lluminação mais eficiente.

Com o avanço das possibilidades de iluminação artificial, alguns preceitos necessariamente passaram a ter maior importância. Por exemplo, uma iluminação eficiente transmite ao usuário uma sensação de segurança: embora o risco, em termos hospitalares, seja formulado em função

${ }^{81}$ VIANNA \& GONÇALVES (2001 apud SAMPAIO, p. 162) 
do procedimento médico, esta sensação tem muita influência no estado emocional do utente.

Outro aspecto importante é o fato de que a iluminação influencia no diagnóstico do paciente. A utilização de cada tipo de lâmpada deve ser escolhida com muito critério em função do procedimento ao qual estará ligada, já que as lâmpadas podem modificar a coloração de pele e induzir a um diagnóstico errado.

Ainda mais: a iluminação artificial tem que ter como objetivo a busca das características da iluminação natural, pois ela influenciará na reflexão e percepção das cores, influindo no ambiente.

É importante, num hospital, poder ser fácil a leitura de um termômetro, bem como serem facilmente notadas quaisquer anormalidades na cor da pele, dos lábios, das unhas... todos os outros sintomas que os procedimentos clínicos mais elementares ensinam e praticam. ${ }^{82}$

De qualquer forma, não importa quão boa a luz artificial seja (e com equipamentos modernos ela pode ser excelente): ela não pode substituir a iluminação natural, a menos que toda nossa concepção de vida e conforto mude. ${ }^{83}$

Analisando estes aspectos da iluminação, tanto a natural quanto a artificial, nos edifícios assistenciais de saúde, pode-se notar o grau de complexidade existente - o que nos faz salientar alguns desafios constantes na elaboração dos projetos, tais como a preocupação com o consumo energético, a valorização dos ambientes e o conforto ambiental.

Mas não são só estes aspectos que devem ser considerados: luz e cor são elementos fundamentais na recuperação e no bem-estar do paciente e estão diretamente ligados. Para se estabelecer o sistema de iluminação e a utilização de cores, deve-se saber o perfil do usuário/ paciente e, principalmente sua patologia, elementos importantes na elaboração de todo o complexo de um edifício de saúde. Cada ambiente tem que ser estudado de acordo com a enfermidade do paciente, a sua idade etc. (GOETHE, 1993, p.139). LIDA ainda coloca:

...para LIDA (2002 apud SAMPAIO, ANA VIRGINIA CARVALHÃES DE FARIA, p. 163) é uma resposta subjetiva para um estímulo luminoso que penetre nos olhos. Quando a luz incide sobre um objeto, parte das ondas luminosas é refletida e parte é absonvida. A cor que enxergamos desse objeto é a que foi refletida por ele. após a incidência da luz e que penetrou nos olhos causando o estimulo e resposta a El por ele,

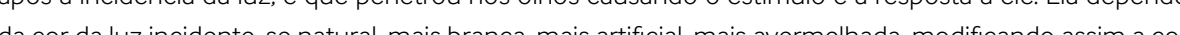
com que o objeto é visto ${ }^{84}$

Acredita-se que a cor tem a capacidade de modificar o ambiente e a orientação do paciente. Por isso, podemos dizer que não há cores belas ou feias e sim a escolha adequada ou não a ser utilizada em cada situação.

${ }_{83}^{82}$ ROSENFIELD (1950, p.285)

${ }^{83}$ Ibidem, p. 284 LDA (2002 apud SAMPAIO, p. 163)
Cores neutras, como o branco e o cinza, têm aparência monótona, além de induzirem à ansiedade tensão, medo e sofrimento; cores frias amenizam a sensação de calor; cores claras transmitem sensação de limpeza e amplitude e cores escuras transmitem sensação de sujeira e claustro.

Além da utilização da cor em si, uma possível combinação delas produz efeitos diferenciados: ambientes com uma só cor dão a sensação de monotonia, ambientes com muita variedade de cores confundem e desagradam.

Vale lembrar, também, que a cor é um estimulante psíquico, podendo afetar o humor, a sensibilidade, produzir emoç̃oes e reflexos sensoriais nos pacientes (COSTI, 2002. p.115.). Mais um motivo para uma detalhada análise quando da escolha dela para a enfermaria. "A experiência nos ensina que cores distintas proporcionam estados de ânimo específicos" ${ }^{\prime 25}$.

ALMEIDA defende o ponto de vista que a cor tem o poder de complementar a terapia: "[... além do efeito psicológico, a cor atua efetivamente como elemento de cura, quando o paciente passa longos períodos sob sua ação." "Na França e nos EUA, a medicina convencional utiliza a cor como complemento das terapias mais usuais."

É importante, também, a preocupação técnica de compatibilização das cores escolhidas com o tipo de iluminação (natural e artificial) da enfermaria e vice-versa. Por exemplo, a cor branca devido à alta refletância, induz à fadiga caso a intensidade da luz não possa ser controlada.

Há também alguns recursos simples, muito utilizadas, como a escolha de cores suaves em pisos e forros a fim de contribuírem para a refletância da luz. Nas superfícies verticais, podese, em função da utilização/objetivo da enfermaria, optar-se por um ambiente acromático, sem saturação, utilizando-se as cores branca, preta e cinza, por exemplo; ou optar-se por um ambiente monocromático em diferentes intensidades e variedades; ou, ainda, optar-se por um ambiente policromático com variedade e intensidade de cores

Enfim, não há uma regra para a escolha da cor ou sistema de cores nas enfermarias. A direção a ser seguida é a mesma para todo o conceito construtivo do estabelecimento: pertinência e adequação ao uso.

\section{G - Presença de verde}

Segundo Malkin (1992 apud MEDEIROS:LUCIANA DE, 2004, p.12), alguns fatores tem a função de propiciar o restabelecimento de pessoas hospitalizadas, entre os quais, podem ser citados, a possibilidade de comunicação com a equipe médica e de enfermagem, o controle de ruídos e a criação de espaços que permitam, por exemplo, a visualização da natureza. ${ }^{87}$

${ }^{85}$ (GOETHE, 1993, . . 140)
${ }_{\text {86 (ALMEIDA 1997) }}$ 
A utilização de vegetação - jardins, internos e externos, ou apenas simples cuidados paisagísticos - nos estabelecimentos assistenciais de saúde, tem benefícios tanto para o paciente, que tem melhor qualidade do ambiente enquanto internado, quanto para a equipe médica e funcionários, conforme comenta SAMPAIO:

Projetar jardins acessíveis nos edifícios hospitalares é benéfico para os administradores, pela redução de custos com medicamentos e tempo de internação, para os pacientes, pelo efeito relaxante, diminuição do nivel de ansiedade, estresse, aumento de independência e para a equipe, por melhorar o seu ambiente trazendo-lhe maior satisfação. 88

"A simples visualização das plantas pode reduzir o estresse" ${ }^{19}$. Lelé, que utiliza o verde em todos os hospitais da rede Sarah, ainda lembra que, além dos benefícios que a vegetação pode oferecer ao paciente, ela também ajuda a melhor resolver as questões de conforto térmico:

Os espaços verdes, nas áreas contíguas à edificação, são indispensáveis também para minimizar o ganho de calor nos ambientes internos. Superfícies como o concreto, em ambientes externos, aumentam o calor por irradiação, no entanto, a areas verdes ou espelhos d aggua servem de amortecedores e propiciam um conforto térmico razoável no entorno da edificação."

Outro artifício muito interessante e bastante utilizado em conjunto com a utilização do verde do ajardinamento cuidadosamente planejado, é a utilização da água, pois ela, além de auxiliar nas questões de regulação do conforto térmico, também influencia na questão do conforto acústico, visual e olfativo, além de trazer para o ambiente uma sensação de aconchego, conforme comenta SAMPAIO:

..uso da vegetação e da água. As plantas, assim como a água, têm grande influência na questão do conforto térmico, visual, acústico e olfativo como também na sensação psicológica de aconchego, de contato com a natureza, que juntamente com a música, quadros e gravuras com motivos naturais, podem interferir positiva e beneficamente no bem-estar dos ocupantes de um ambiente, principalmente quando se tratar de um ambiente hospitalar e seu usuário for um ser fragilizado, que se encontra acamado, imóvel e sensível a todos os estímulos deste ambiente. ${ }^{91}$

A água também transmite a sensação de frescor, tranquilidade, paz e usada em movimento, pode ampliar os efeitos psicológicos positivos em usuários sob tensão ou para descontrair, relaxar os que exercem atividades que exijam excessiva concentraç̃ão.

\section{H - Relação interior $x$ exterior}

A questão da relação entre o interior e o exterior está bastante ligada à questão da presença do verde pois é através dela que se busca proporcionar um diálogo entre as áreas internas e externas do edifício, através das aberturas. Quando se fala nesta relação, não necessariamente

\section{${ }_{88}^{88}$ SAMPAIO (2004, p. 183}

${ }_{90}^{89}$ bidem, p. 173

91 LIMA (2005 apUd MONTERO, 2006, p. 153)

92 SAMPAIO (2004, p. 173 ) deve-se entendê-la apenas como acesso de ligação física, mas também de ligação visual: composição de claros e escuros, transparências e opacidades, cheios e vazios etc. Quando esta ligação é estabelecida e consegue-se, por exemplo, fazer com que a área externa seja uma continuidade da área interna, a relação está estabelecida de maneira muito eficiente.

Esta relação harmônica entre o exterior e o interior é importante não só para se ter acesso às áreas verdes, mas também para se viabilizar acesso à ventilação e iluminação natural, o que traz muito conforto ao usuário principalmente ao paciente. Por causa do fator psicológico - extremamente importante -, trabalhadores têm afirmado que embora gostem do conforto estabelecido por condições controladas, também gostam de vidro suficiente para ao menos verem como o tempo está. (ROSENFIELD, 1950, p.284). Já no caso dos pacientes, outro aspecto é garantido por esta relação: a sensação de segurança. Não a sensação de segurança usual, mas a sensação de segurança que é adquirida com a percepção de dia e noite. Um paciente moribundo está longe de mostrar as emocões, quer o sol brilhe ou não, mas até isto às vezes não é verdade. Um paciente muito doente às vezes prefere um nível mais baixo de luz; luz abundante pode ser facilmente controlada para o nível desejado, usando cortinas ou persianas. O paciente usual, contudo, particularmente os de longa estadia no hospital, que passam dias, semanas e até meses, anseiam ardentemente pelo prazer da luz natural e o da vista do céu. (ROSENFIELD, 1950, p. 285)

"... o doente internado fica desligado do 'mundo exterior', a sensação de abandono, medo do desconhecido, descontentamento e desgosto pode acompanhá-lo durante a sua estada no local|"93. CAPMAN faz algumas recomendações:

CAPMAN et al.(1986 apud SAMPAIO, ANA VIRGINIACARVALHÃES DE FARIA, p. 198) fazem recomendações com relação às áreas externas. Se possível, todos os ambientes devem ter acessos a áreas sombreadas. com fontes de água, vegetação, local adequado e confortável para sentar, para que possam caminhar acompanhados de enfermeiros e acessível para cadeiras de rodas e macas. No caso de pacientes que não possam ir para fora as janelas devem permitir o contato com o exterior para que eles possam

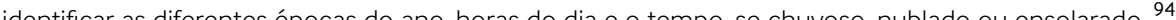

Além de tudo, a relação do paciente com o exterior, oferece a ele um relaxamento físico psicológico, conforme comentam HOPKINSON \& KAEY:

De acordo com HOPKINSON \& KAY (1969 apud SAMPAIO, ANA VIRGINIACARVALHÃES DE FARIA, p. 186), uma janela possibilita descanso visual pois permite uma ligação direta com o mundo exterior, com as diferentes variacões que ocorrem no decorrer de um dia 0 homem tem necessidades de variac̃a mudança e as janelas favorecem um relaxamento físico e psicológico, pois permitem o

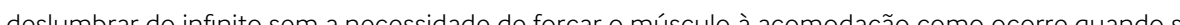
observa alguma coisa próxima ${ }^{95}$

${ }^{93}$ MEDEIROS (2004, p. 30 95 apud SAMPAIO, p. 198 SAMPAIO (2004, p. 187) 


\section{I - Humanização dos espaços}

Humanização da assistência hospitalar é um termo abrangente utilizado para definir um movimento em busca da valorização da pessoa que faz uso dos serviços de saúde, considerando o paciente e o profissional como parte essencial no processo, sendo o primeiro o principal foco da atenção. ${ }^{96}$

O termo humanização dos ambientes hospitalares tem sido muito veiculado, tanto pelos autores analisados, como ANELLI, GUERRA \& KON, COSTI, DALLAS, FIGUEIREDO, GERROLA. GODOI, GOLDENSTEIN, LEÃO, LIMA, MALKIN, MEDEIROS,PRUDENTE, REIS, TOLEDO entre outros, quanto pela área médica como um todo. Está claro, porém, que esta questão, embora seja importante para a recuperação do utente, como aborda o próprio Ministério da Saúde na Política Nacional de Humanização do SUS (humanizaSUS), nem sempre é abordada, em nível prático, em primeiro plano.

REIS, em sua Monografia "O Ambiente como Recurso Terapêutico nos serviços Públicos de Saúde", pela Faculdade de Terapia Ocupacional, descreve, através dos comentários a seguir - e de maneira bastante eficiente -, a situação do paciente que passa praticamente por um processo de despersonalização, a preocupação com sua acolhida no hospital e também a adequação entre ele e o ambiente:

Um dos fatores externos, já bastante estudado e que pode causar instabilidade no desenvolvimento humano é o ambiente hospitalar e ambulatorial, que rompem com a rotina familiar, relações sociais e atividades do dia-a-dia. Apesar de terem como finalidade a melhoria da saúde do enfermo, muitas vezes as intervenções são dolorosas, podendo até ser mutilantes, gerando transformações corporais e traumas psicológicos. As rotinas nestes serviços são impostas e o paciente, muitas vezes, passa a ser despersonalizado, passando de pessoa a um número.

Dentro dos hospitais existem diferentes ambientes nos quais os enfermos são divididos por diversas características como: gravidade da enfermidade, idade, tempo de hospitalização, entre outros. Os profissionais da saúde tem como função adequar estes ambientes o máximo possivel, para que 0 enfermo possa se sentir acolhido, ajudando na sua própria melhora ${ }^{98}$

Nos quartos hospitalares deve-se verificar a ventilação, a iluminação e se a posição do leito permite a deambulação do enfermo. Além disso deve-se levar em conta a opinião do paciente e da família se houver a possibilidade de mudanças nos locais dos mobiliários e objetos. ${ }^{99}$

Também é importante lembrar que a questão da humanização dos ambientes hospitalares não está unicamente vinculada à arquitetura. Na verdade a arquitetura pode agregar valores objetivos e subjetivos aos espaços projetados e aí sim. somarem-se estes aos demais elementos que tornam os ambientes hospitalares realmente humanos. A arquitetura é uma parcela a ser somada no todo pela busca na eficiência do tratamento humanizado para o paciente.

Capaz de despertar sentimentos, o ambiente ajuda no tratamento e adaptação do paciente devendo, portanto, ser adequado a cada usuário. Do mesmo modo, complementa COSTI:

... descobriu-se que o espaço das pessoas tinha relação com seu eu interior, que os efeitos da luz e da cor interferiam tanto na parte física quanto na parte emocional dos seres humanos e que a noção de tempo ficava alterada. ${ }^{100}$

Importante salientar que, com a evolução do aparato tecnológico hospitalar e do conhecimento sobre o comportamento emocional dos pacientes, cada vez mais forte se torna a preocupação com este requisito: [... a evolucão do hospital e sua nova imagem modificada pelas tecnologias e humanização dos espaços
gerou o aparecimento de edifíicios que primam pelo conforto do paciente.

Vale lembrar que este requisito não é como os outros, um requisito exclusivamente técnico e sendo assim, torna-se um desafio ao arquiteto projetista atendê-lo. Sabe-se que o expedito atendimento dos demais requisitos básicos mencionados anteriormente já torna este desafio muito mais fácil de se enfrentar, pois se o estabelecimento de atendimento à saúde for adequadamente implantado, o projeto for eficiente do ponto de vista funcional, as circulações e agrupamentos forem adequadamente racionalizados, se existir uma preocupação decisiva com a questão do conforto ambiental, com a presença do verde e a relação entre interior e exterior. uma grande parcela do requisito mais geral da humanização estará garantida: certamente os ambientes deverão ser mais agradáveis, tanto para os pacientes em recuperação, quanto para a equipe que deles trata.

A questão que precisa ser esclarecida é que, atualmente, na grande maioria dos estabelecimentos assistenciais de saúde, a questão da humanização dos espaços representa um diferencial um algo a mais, geralmente associado à valoração de um produto disposto como mercadoria, quando, na verdade, deveria ser tratada, consensualmente, como uma questão essencial, principalmente pelo fato de qualidade, nos termos propostos e a partir dos requisitos discutidos anteriormente, não representar, necessariamente, custos adicionais ou excessivos quando da implantação e construção da edificação.
96 MEEEIROS (2004, p. 12)
97 REEIS (2000, p.14)
98 Ibidem, p.15

${ }_{99}^{98}$ Ibidem, p. 15 


\subsubsection{Críticas}

Em função da revisão bibliográfica assistemática aqui apresentada - além da condição experimentada como usuário comum -, seria possível esboçar diversas críticas aos pressupostos atualmente utilizados para se pensar, especificamente, a arquitetura nos estabelecimentos assistenciais de saúde. Duas delas, contudo, são mais relevantes quando relacionadas ao trabalho de pesquisa em desenvolvimento.

A primeira crítica relaciona-se à interpretação do conceito de humanização que ocorre na prática. Pode-se ver claramente, principalmente nos hospitais particulares, uma valorização do luxo, dos serviços de hotelaria, apresentados como 'humanização' dos espaços. Obviamente, todo ser humano gosta de conforto e luxo, mas não é esse tipo de 'humanização' que traz qualidade ao ambiente. Ele pode sim ser utilizado, não se pode ser contra esse tipo de artifício. O que precisa ficar claro é que o luxo ou os serviços de hotelaria nada mais são que elementos opcionais de composição de atendimento ao usuário, para além do estrito atendimento à saúde e que será comprado por aquele indivíduo que pode e quer pagar por eles. Mas eles não devem ser considerados como fator que torna o ambiente mais ou menos humano.

O que se vê hoje é que "... enquanto hospitais privados têm aparência física de sua estrutura considerada como humanizada, hospitais públicos enfatizam a humanização do atendimento, num contraste que reforça as contradições do sistema de saúde do país."102

Atualmente, o que se nota - principalmente nos estabelecimentos assistenciais de saúde particulares - é uma valorização da 'humanização' dos ambientes, configurada, na verdade, pela composição do produto que se coloca à venda como serviços de hotelaria ou mesmo de luxo. 0 que vemos é, visivelmente, uma estratégia de mercado e de marketing, preconizando a humanização e o atendimento diferenciado apenas como um diferencial de produto. Como observa Godoy:

O modelo de hotel (..), segundo Miller e Swensson (1995 apud MEDEIROS; LUCIANA DE, 2004, p. 49) fol uma forma de proporcionar uma estada confortavel para pacientes e familiares durante a internação dos primeiros, além de possibilitar uma vantagem a mais para 'atrair' clientes. ${ }^{103}$

... hotelaria hospitalar e a introdução de técnica, procedimento e serviços de hotelaria em hospitais com o consequente benefício social, físico, psicológico e emocional para pacientes familiares e funcionários. ${ }^{104}$

Não há problema algum em se oferecer luxo para quem o quer e por ele pode pagar. No entanto, o grande problema é confundi-lo e amalgamá-lo como e enquanto atendimento essencial - o que ocorre quando ele é confundido com a idéia de humanização:

\section{${ }^{102}$ MEDEIROS (2004, p. 09)}

103 Ibidem, p.49

(104. existe uma tendência em comparar a estrutura de determinados hospitais à de hotéis, atribuindo-lhes a qualidade de 'humanizado' devido à variedade das opç̃os de seniço de conforto oferecido ao paciente. 105

Como se viu, humanização é o conceito que garante ao paciente um atendimento mais humano mais próximo e que depende de uma série de fatores, dentre eles o ambiente confortável. Aparelhos eletrônicos como TVs de última geração, janelas controladas por controle remoto, camas com ajustes automáticos, jogos de cama diferenciados, tratamento especial etc. pode até tornar o ambiente mais agradável e tolerável para quem pode pagar por isso. Mas, e para a imensa maioria da população que depende do sistema público de saúde? Se a humanização assume a condição de "produto diferencial" - e valorado como tal -, então não é possível um atendimento humanizado para esta população?

Claro que é, se o conceito de humanização for entendido corretamente. Um ambiente pode sim ser humanizado sem luxo algum. Os aspectos necessários para torná-lo humanizado são básicos e independem do luxo e da hotelaria e consistem no conforto ambiental, no atendimento adequado e bem informado, na boa relação do ambiente interno com o meio externo, na presença de verde e em outros já comentados e discutidos.

A segunda crítica que se pode ressaltar é relativa à legislação que regula os projetos, obras, utilização e procedimentos dos ambientes assistenciais de saúde. O que se vê ao analisar estas normas ou a legislação específica, é que ela é bastante limitada e bastante focada em questões técnicas, muito mais voltadas para procedimentos, dimensionamentos dos ambientes e para materiais aplicados e muito pouco preocupada com a questão conceitual que dá suporte à concepção dos projetos e obras, que é o que garante $\mathrm{o}$ atendimento aos requisitos básicos apresentados. Nitidamente, atribui-se apenas ao bom senso do projetista, o compromisso de elaborar um bom e eficiente projeto. Ou seja, seguindo-se todas as normas atualmente vigentes, pode-se tanto elaborar um excelente, quanto um péssimo projeto de estabelecimento. Ambos atenderão a todas as normas. Serem, afinal, eficientes é outra questão.

Também não se pode deixar de colocar que cada estabelecimento tem suas particularidades e é papel do arquiteto adequá-las em cada projeto:

É necessário também estar ciente de que, mesmo existindo normas projetuais, as diferenças programáticas e de dimensionamento muitas vezes impõem solucões diferenciadas que independentemente da maior ou menor experiência do arquiteto, só poderão ser criadas por meio do trabalho de equipe. ${ }^{106}$

O que definitivamente não existe é uma norma reguladora para os critérios que podem ser 
chamados de "requisitos que influenciam na recuperacão do paciente". O que acontece é uma solução muitas vezes desorientada, que visa sim melhorar a qualidade do ambiente e consequentemente influenciar na recuperação do paciente, porém sem critério algum, conforme vemos na citação de REIS:

Nos servicos ambulatoriais, além do aparato tecnológico disponivel para a atuaç̃o profissional, no setor público, consideram-se regras da ABNT para a construção de serviços de saúde como espaço, número de sanitários, entrada e saída e também regras de Vigilância Sanitária como salas com azulejos, materiais de fácil limpeza, cores neutras, entre outros. Não há estudos apontando fatores como cores, odores, texturas, disposição de mobiliário e objetos que demonstrem sua importância. Deste modo, o que ocorre é geralmente uma certa padronização destes elementos no serviço público. Os elementos próprios de cada serviço acabam ficando por conta dos profissionais que lá trabalham. ${ }^{107}$

Em função das etapas subsequentes, retornar-se-á a estas críticas com elementos novos que poderão trazer pontos de vista diferentes de forma a contribuir para a discussão dessa temática.

\subsection{Relação Arquitetura X Humanização}

Um dos objetivos principais desta pesquisa é analisar o conceito de humanização hospitalar entendê-lo em seu aspecto multidisciplinar e compreender o papel da arquitetura na composição interativa do complexo profissional articulado em torno da humanização dos espaços dedicados ao tratamento da saúde.

Este entendimento vai se tornando mais claro, conforme a revisão bibliográfica vai sendo construída. Fica evidente que a arquitetura é somente um elemento na questão da humanização do atendimento como um todo. Embora somente um elemento, mas não menos importante que os demais, já que "...espaço físico e atendimento são essenciais ao processo de humanização"108 Conforme MEDEIROS ainda nos mostra:

Nessas discussões, entretanto, não costuma haver referência à arquitetura como fator relevante para a humanização hospitalar, embora já se saiba que a estrutura física do edifício pode auxiliar no amenizar o impacto causado pela rotina hospitalar sobre os pacientes. ${ }^{109}$

Humanização da assistência hospitalar é um termo abrangente utilizado para definir um movimento em busca da valorização da pessoa que faz uso dos serviços de saúde, considerando o paciente e o profissional como parte essencial no processo, sendo o primeiro o principal foco da atenção. ${ }^{10}$
Como já comentado, a arquitetura dos estabelecimentos assistenciais de saúde é a arquitetura voltada para o ser humano talvez em seu estado de maior fragilidade. Entendendo-se desta maneira a arquitetura, fica clara a sua importância com relação ao bem-estar ou mesmo à recuperação do paciente. "...WINNICOTT revela o ambiente como fator fundamental para o equilíbrio mental do indivíduo. 0 ambiente, quando adequado, torna-se facilitador do processo de maturação do lactente..."111. TOLEDO ainda salienta:

podemos considerar que a definição, os objetivos e as propostas de humanização ainda se encontran em processo de construção. Sendo assim com o objetivo de participar dessa construção, lembramos princípios que regem uma boa arquitetura

Acreditamos, portando, que a humanizaç̃ão do edificio hospitalar resulte de um processo projetual que não se limita à beleza do traço, ao respeito à funcionalidade ou ao domínio dos aspectos construtivos, e alia a esses aspectos a criação de espaços que, além de favorecer a recuperação da saúde e garantir o bem-estar físico e psicológico aos usuários do edificio hospitalar, sejam eles pacientes acompanhantes ou funcionários, possa estimular a incorporação de novos procedimentos às práticas médicas. ${ }^{112}$

Há, também, quem vá mais além e defenda que o ambiente de atendimento de saúde precise ficar o mais parecido possível com o ambiente do dia-a-dia do paciente:

JORGE acredita que o ambiente terapêutico em um gabinete fisioterapêutico ou numa oficina terapêutica ocupacional deve ser composto por ambientes amplos, fartamente iluminados, podendo ou não ter barulho, fortes odores de tinta, parafina, vernizes, óleos etc. Por mais que perca a fantasia da relação terapêutica em um ambiente acolhedor, cálido, semi-escurecido, sugerindo discrição e calma, isto não significa que nestes ambientes não se consiga níveis profundos de relaxamento, confidências. encontros, até porque os ambientes urbanos e domésticos da maioria dos seres humanos são conturbados, barulhentos e possuem uma grande diversidade de odores, entre outros aspectos. ${ }^{113}$

SAMPAIO ressalta que a arquitetura tem a obrigação de ser voltada para o utente, para o ser humano:

A preocupação com os pacientes deve existir em todo o projeto, desde a concepcão, como um todo. até nos detalhes do seu interior. Cores, texturas, aberturas para visualizacão do exterior e entrada de auxiliam na recuperação do paciente. ${ }^{114}$

Também para os administradores esse enfoque tem se mostrado compensador. Analisando-se doze estabelecimentos filiados ao Planetree constatou-se que houve uma maior satisfação por parte dos pacientes e a sua recomendação para amigos e familiares. Foi posśvel relacionar também. a esses ambientes um menor número de erros médicos e diminuição da taxa de infeção Na major pate dos 
Maior prova de que este ponto de vista é acertado pode ser vista nos depoimentos dos pacientes do Maggie's, no documentário de Alan de Boton - Arquitetura da Felicidade - transcritos a seguir:

A primeira vez que eu entrei aqui eu parei e... Havia paz e tranquilidade neste lugar que realmente me ajudou. E, ao subir as escadas para olhar o rio pela janela senti que a tranquilidade do lugar me ajudou. (paciente diagnosticada com câncer em entrevista para Alan de Botton)

Aqui, você pode entrar e sair e é esteticamente agradável para mim. É bonito, é relaxante. Se você quiser ir a algum lugar, acho que ajuda se o local for agradável. (paciente em entrevista para Alan de Botton)

Sempre me sentia muito mais calma quando vinha aqui. Não sei se era por causa da luz ou da vista. Ou se muito natural. Eu sentia que podia me desligar. (paciente em entrevista para Alan de Botton)

Creio que as estruturas interna e externa, com as formas arredondadas da parede, daquela mesa, daquela escada Há poucas arestas e ângulos retos isso deixa o lugar mais envolvente. Sempre penso nele como aloo bem redondo onde posso entrar e. (paciente em entrevista para Alan de Botton)

Aqui, sinto-me livre, alerta, confiante, com a mente mais clara. Meus reflexos melhoram, sinto-me intelectualmente melhor porque há algo no lugar que faz com que eu me conheça melhor. Sinto-me confiante ao pensar nessas coisas. É um espaço maravilhoso que nos dá uma espécie de liberdade. (paciente em entrevista para Alan de Botton)

A Arquitetura certamente está entre os mais importantes elementos que compõem o conceito de humanização hospitalar. Ela tem o poder de tornar os espaços mais humanos e, sendo os espaços mais humanos, estes influenciam tanto a equipe de tratamento quanto os pacientes de maneira benéfica, aumentando assim o potencial ambiental de cura ou recuperação destes pacientes. Uma arquitetura de qualidade facilita o estabelecimento da organicidade dos demais elementos que influenciam na recuperação do paciente e, desta maneira, assume uma importância central em todo o processo de humanização - o que a torna indispensável. Ela tem um caráter único que não pode ser desconsiderado: a arquitetura pode ser entendida como uma humanização permanente e segura. Dentro de todo o processo, a arquitetura é o elemento mais estático e duradouro. A partir dela todos os demais elementos poderão se desenvolver melhor.

Um bom projeto de estabelecimento assistencial de saúde é aquele que olha o edifício pela perspectiva do paciente. Este fator é tão importante que é o fundamento para que, em qualquer lugar do mundo, com qualquer técnica construtiva, com qualquer recurso financeiro, torne-se possivel conceber a idéia de humanização destes ambientes como uma idéia universal. Desta maneira, o pressuposto de se apreender esta arquitetura sob o "olhar do paciente", pode ser entendido como sendo um preceito também universal.

Fica claro, então, que a arquitetura é instrumento e método importante neste processo, porque a arquitetura, se compreendida em sua essência, é, em si, atividade que produz efeitos universais. Se os conceitos básicos que dão substrato ao projeto forem plenamente atendidos, a tão buscada humanização é possível inclusive sem luxo algum. 
Capítulo 4

Arquitetura

e Humanização

na Prática

Hospitalar 
Aqui, se pretende analisar de maneira crítica alguns exemplos práticos: alguns hospitais. Conhecer alguns hospitais, todos conhecem pelo menos de passagem em função de em determinados momentos necessitar-se de sua estrutura. O que se busca aqui é obter uma visão um pouco mais aprofundada que permita entender além daquilo que os usuários veem. Entender como e porque tudo funciona e como estas instituições se mantêm, conseguindo prestar atendimento de qualidade a seus usuários.

A idéia não é fazer um estudo de caso, que nos traria resultados aprofundados a respeito de uma instituição. Aidéia é entender de maneira menos detalhada, uma quantidade maior de ambientes que permita contribuir de maneira bastante clara no trabalho de avaliação e entendimento da situação dos ambientes. Como já fora colocado, buscou-se por instituiç̃es de atendimento ao público do SUS por entender-se a situação de maior dificuldade de manutenção em função dos escassos recursos e consequentes dificuldades financeiras, situação esta que se comprova nas visitas realizadas conforme será entendido quando da descrição de cada uma delas.

As instituições escolhidas foram: Hospital Escola de São Carlos, Hospital do Câncer de Barretos, Santa Casa de Porto Alegre e Santa Casa de São João da Boa Vista.

O critério adotado para esta escolha foi o seguinte:

Em primeiro lugar, todas as instituiç̃̃es têm ligações bastante fortes com o trabalho, quer seja física ou emocional. Ligação física pelo fato de serem hospitais desta região. 0 Hospital Escola de São Carlos e a Santa Casa de São João da Boa Vista, são hospitais considerados do dia-a-dia, ou seja, fazem parte do cotidiano, pois encontram-se instalados na cidade onde se desenvolve o estudo em questão e por ser o hospital da cidade de residência do pesquisador respectivamente. A Santa Casa de Porto Alegre, tem forte ligação emocional por ter feito parte de momento importante da vida familiar deste pesquisador, e que, em grande parte contribuiu para o desenvolvimento deste trabalho. Importante salientar que para o desenvolvimento do trabalho experiências cotidianas ou vividas nestes estabelecimentos não devem ser encaradas de forma unicamente emocional, mas sim como vivências que se somam à pesquisa e análise de campo. 
Em segundo lugar, buscou-se eleger instituiç̃es que podem ser consideradas referências quanto ao atendimento SUS. O Hospital do Câncer de Barretos e a Santa Casa de Porto Alegre, tem reconhecido trabalho nesta vertente. Já o Hospital Escola de São Carlos, embora não tenha este reconhecimento, revelou-se também de excelente qualidade em seu atendimento que é feito exclusivamente ao SUS

Em terceiro lugar, estas escolhas fecham um raciocínio de escolha que fornece os parâmetros em uma vasta área de atuação, pois tem-se um hospital de pequeno porte que existe replicado e distribuído em praticamente todo o país (Santa Casa de São João da Boa Vista), um hospital de grande porte e complexidade (Santa Casa de Porto Alegre), um hospital de ensino (Hospital Escola de São Carlos) e um hospital especializado (Hospital do Câncer de Barretos).

Como estratégia de pesquisa, optou-se por visitas técnicas a cada estabelecimento. Tais visitas foram realizadas com duração de um dia em cada um deles onde se buscou conhecer os espaços a analisá-los com um olhar diferenciado técnico e de pesquisador afim de melhor se entender as alternativas buscadas para cada espaço, seu funcionamento e sua utilização. Sabendo-se da limitação que tal estratégia impõe, buscou-se também colher depoimentos em cada um desses estabelecimentos analisados.

No Hospital Escola Municipal de São Carlos, com este ainda encontra-se em obra, foram colhidos dois depoimentos: um do engenheiro responsável pelo acompanhamento da obra em execução e manutenção da área finalizada e outro com a funcionária responsável pelo setor de imagem que está em funcionamento desde sua inauguração. 0 primeiro depoimento foi colhido praticamente durante toda a visita pois tal engenheiro foi o responsável por apresentar a área em funcionamento, os projetos e também a obra em execucãa

No Hospital do Câncer de Barretos, a responsável pelo acompanhamento da visita, foi funcionária administrativa responsável pelo setor de turismo da instituição. Desta forma, como tal pessoa acompanhou toda a visita e apresentou todo o complexo, seu depoimento foi collhido com riqueza de detalhes não somente referente à estrutura física e funcional do hospital como também de seu funcionamento e administração. Como ela tem esta função - a de apresentar aos visitantes o complexo -, seu depoimento foi extremamente proveitoso e esclarecedor.

No complexo da Santa Casa de Porto Alegre, foram colhidos diversos depoimentos: o principa foi o do funcionário responsável pelo setor de comunicação da instituição que apresentou todo a estrutura além de ajustar entrevistas com o diretor financeiro da instituição, o arquiteto responsável há 20 anos pelas obras do complexo e também com a diretora técnica responsável pelo grande hospital geral do complexo. Desta forma, a visita ao complexo tornou-se também muito eficiente e esclarecedora.

Na Santa Casa Dona Carolina Malheiros de São João da Boa Vista, a visita foi recebida pelo atual provedor que de forma resumida colocou as principais características do estabelecimento. A visita física em si foi acompanhada e orientada pelo diretor financeiro da instituição.

Desta forma, vale salientar que todas as visitas geraram depoimentos detalhados pois foram totalmente acompanhadas de profissionais que atuam no dia-a-dia de cada instituição. Mais que isso: trabalham há anos nelas e buscam ajudar em sua sobrevivência e desenvolvimento conhecem as dificuldades e vitórias de cada instituição - fazem parte da história delas.

Vale colocar de forma bastante clara que esta análise em momento algum visa estabelecer um ranking ou mesmo um comparativo entre tais estabelecimentos, mesmo porque cada um tem sua especificidade, estão localizados em regiões bastante distintas e tem modo funcional bastante particular.

Abaixo, segue tabela que visa colocar de forma bastante clara e didática as principais características de cada estabelecimento de forma não comparativa mas sim explicativa e introdutória para se entender melhor cada uma das unidades estudadas.

\begin{tabular}{|c|c|c|c|c|c|}
\hline \multirow[b]{2}{*}{ ESTABELECIMENTO } & \multicolumn{5}{|c|}{ DADOS } \\
\hline & LOCALZAÇ̄̃o & NUMERO DE LEITOS & ÁREA CONSTRUÍDA & GESTÃO & $\begin{array}{l}\text { CARACTERISTICA DE } \\
\text { FUNCIONAMENTO } \\
\end{array}$ \\
\hline $\begin{array}{l}\text { HOSPITAL ESCOLA MUNICIPAL DE SÃO } \\
\text { CARLOS }\end{array}$ & 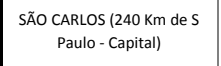 & 0 & $30000 \mathrm{~m}^{2}$ & $\begin{array}{l}\text { Universidade Federal des. } \\
\text { Carlos }\end{array}$ & hospital geral \\
\hline HOSPITAL DO CÂNCER DE BARRETOS & 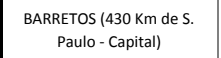 & 80 & $24000 \mathrm{~m}^{2}$ & Fundaçăo Pio XII & hospital especializado \\
\hline SANTA CASA DE PORTO ALEGRE & \begin{tabular}{|c|c|c|} 
Porto ALEGE- Capital do \\
Estado
\end{tabular} & 1070 & $130000 \mathrm{~m}^{2}$ & irmandade & $\begin{array}{l}\text { hospital geral com } \\
\text { especialidades }\end{array}$ \\
\hline SANTA CASA DONA CAROLINA MALHEROS & 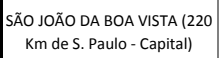 & 160 & $13000 \mathrm{~m}^{2}$ & irmandade & hospital ereal \\
\hline
\end{tabular}

\subsection{Hospital Escola Municipal de São Carlos}

Os dois maiores motivos pela escolha de estudo sobre o Hospital Escola Municipal de São Carlos "Prof. Dr. Horácio Carlos Panepucci" são: primeiramente, o fato de estar instalado em São Carlos cidade base de desenvolvimento desta dissertação; depois, por ser um hospital projetado por João Filgueiras Lima (Lelé), o que confere a ele uma particularidade que não poderia deixar de representar certa diferenciação quando comparado a qualquer outros hospitais da região. 
Atualmente, somente a primeira das três etapas construtivas do hospital está finalizada. Esta primeira etapa concluída e que já está funcionando compreende o Pronto Atendimento, dos ambulatórios adulto e infantil e da área destinada à radiologia. Tal situação fez com que a visita não se tornasse tão interessante, pois o ideal é se analisar o complexo em funcionamento como um todo, com todas as suas particularidades, funcionamentos e complexidades.

Importante colocar que pelo fato de atualmente a área em funcionamento do hospital não apresentar leitos de internação, este estabelecimento ainda não pode ser considerado um hospital e sim uma Unidade de Pronto Atendimento. Toda a pesquisa trata este estabelecimento como hospital porém ciente que este ainda não está totalmente implantado, Desta forma, mais um aspecto que prejudica sua análise quando em comparação com os demais estabelecimentos em estudo.

A seguir implantação esquemática com destaque à área em funcionamento.

Fig. 02 Implantação do Hospital Escola Municipal de São Carlos, destacando etapa Fonte: MONTERO (2006)

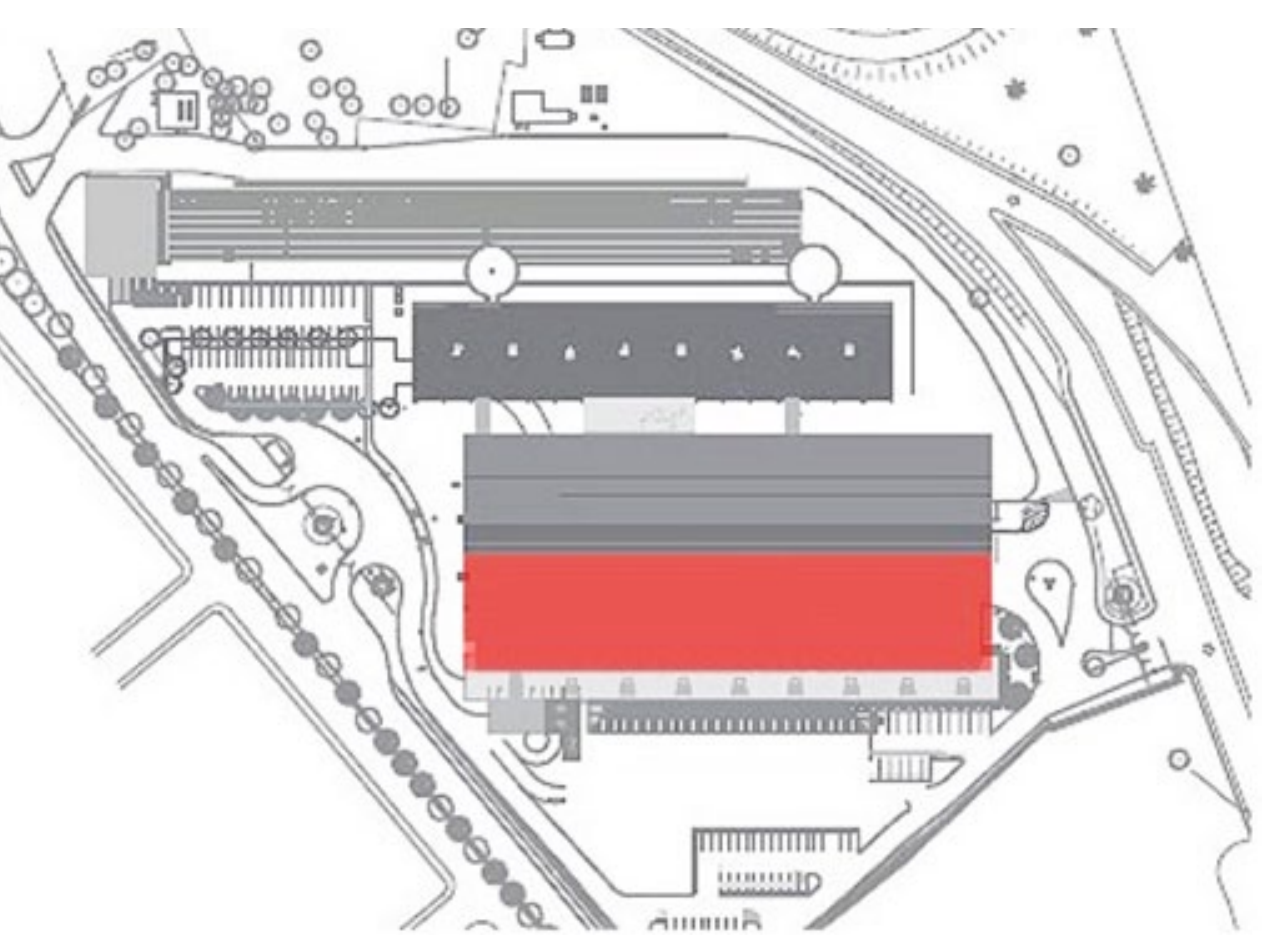

O objetivo é que este hospital seja um hospital de grande porte com total de aproximadamente 30.000 metros quadrados de área construída e que seja referência no atendimento dedicado exclusivamente ao SUS. O hospital busca integrar a rede de saúde pública à rede escola-pesquisa e será administrado pelo curso de medicina da Universidade Federal de S. Carlos - UFSCAR.
O orçamento da obra já está em torno de 49 milhões de reais, valor este empregado conjuntamente pelo Governo Federal e pelo Município e, embora o montante possa parecer alto, ao se fazer uma análise mais cuidadosa permite concluir que o valor em reais por metro quadrado encontra-se em torno de 1620 reais, o que não é exatamente alto ao ser comparado com valores de hospitais convencionais não dotados da quantidade de tecnologia que os hospitais projetados por Lelé apresentam. Obviamente ainda há valores adicionais a serem considerados que são os valores para se equipar tal hospital, que estarão na faixa de 30 milhões de reais. Mas, o equipamento tem seu custo independentemente do projeto arquitetônico, pois está-se falando de equipamentos médicos.

Descrição física e percepção

A tipologia deste hospital em muito se parece com os hospitais da Rede Sarah que são marcados pelas características arquitetônicas de seu projetista: Lelé. Há a existência dos grandes sheds que visam a qualidade na ventilação e iluminação natural, há a presença de um grande espelho d’água que tem fundamental papel no condicionamento natural do conforto térmico interno assim como a existência do subsolo técnico que visa a garantia de melhor ventilação e instalações em geral. Tudo que geralmente se pode encontrar nos projetos destinados à Rede Sarah de Hospitais, também se pode encontrar aqui, porém, de forma adaptada ao uso desta unidade.
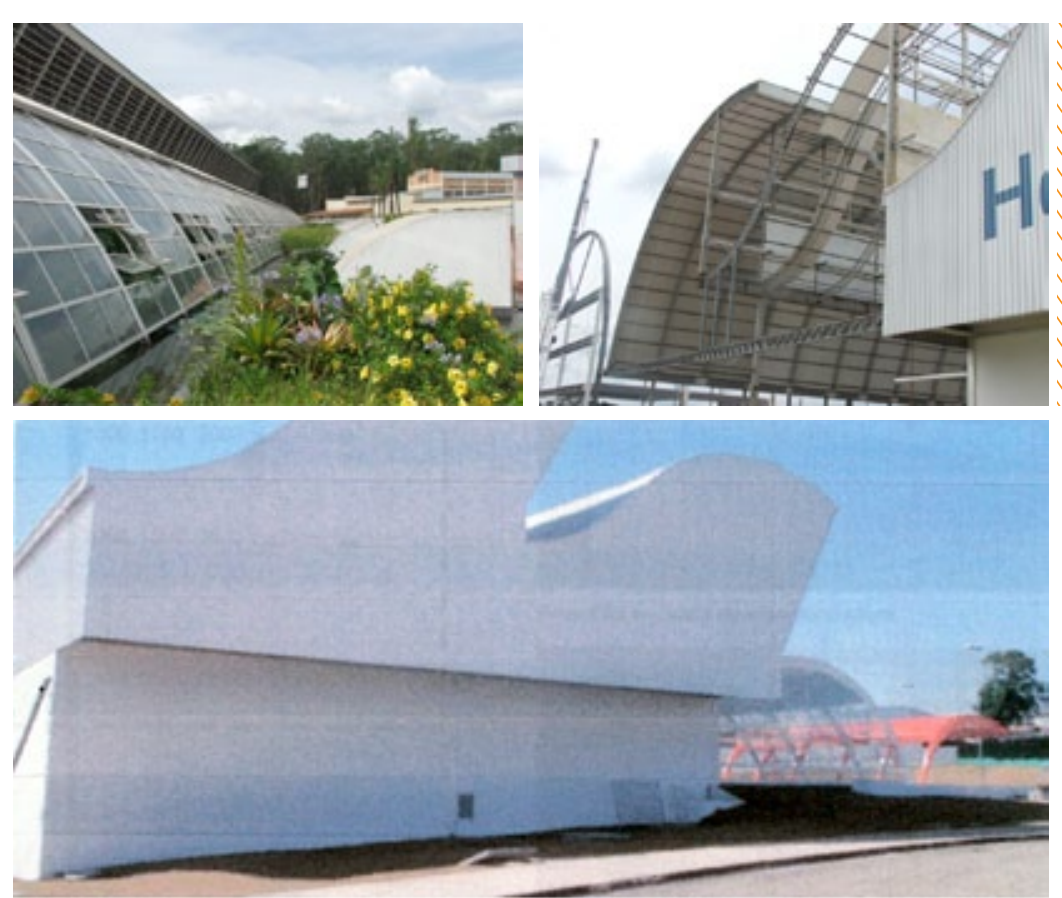

\section{Fig. 03}

Fotos gerais do Hospital Escola Municipal de São Carlos Fonte: MONTERO (2006) acervo pessoal 
Um exemplo da adequação do sistema ao local, é o fato de na região de São Carlos haver em determinada época do ano, uma quantidade de queimadas muito grande em função da grande quantidade de áreas destinadas ao plantio da cana-de-açúcar. Tais queimadas colocam na atmosfera local uma grande quantidade de fuligem que consequentemente acabavam por comprometer o funcionamento dos sheds que visam a ventilação natural. Segundo o engenheiro do departamento municipal responsável pelo acompanhamento e fiscalização da obra, tal situação foi resolvida com a instalação de telas junto às aberturas no ponto mais alto dos sheds. São situações como estas que muitas vezes tornam a adequação do sistema ao local mais complicada e trabalhosa, porém absolutamente necessária.

O fato é que internamente, o ambiente realmente parece ser muito agradável quando se fala em conforto térmico. Há mecanismos de controle total da circulação de ar que se dá através dos forros compostos por aletas de policarbonato móveis, com funcionamento motorizado por ambiente.

Embora não existam ainda instaladas as áreas destinadas às enfermarias, e consequentemente não se possa analisar a influência deste ambiente na recuperação dos utentes, uma volta rápida pelas instalações em funcionamento demonstram claramente a qualidade que se terá em todo o complexo. A relação entre interior e exterior, a presença de água e paisagismo, o conforto térmico entre outras características tornam os espaços com alto grau de agradabilidade.

A princípio, chama a atenção quando se dá conta de que tudo é feito para atendimento aos usuários do Sistema Único de Saúde Obviamente não porque tais usuários não mereçam ou não tenham direito a ele, mas pelo fato de normalmente tais espaços destinados a esse público serem geralmente não explorados com tamanha qualidade. Obviamente que, a não ser que seja pelo atendimento de emergência, não é todo cidadão que consegue ser atendido neste local. 0 tumulto existente nos grandes hospitais gerais oriundos da grande demanda pelo atendimento existe neste caso também, porém uma saída alternativa é utilizada quando todo o processo de triagem e agendamento do atendimento é feito em local separado. Desta forma, o ambiente encontra-se sempre bem organizado, sem filas de espera ou tumulto. Características estas que se tornam fontes de contrapartida à qualidade oferecida pelo ambiente. $\mathrm{O}$ que ocorre, na verdade, é a transferência do problema para outra unidade dali afastada.

De maneira geral, em função do ambiente já construído e do que está sendo construído pelo valor em reais divulgado, em torno de $R \$ 1620,00$ por metro quadrado, obrigatoriamente temse que concluir que é muito viável e acessível se oferecer qualidade e humanização - pelo menos em seus requisitos básicos - a qualquer hospital. Oferecer qualidade não o torna inviável. Provavelmente custa menos que decorá-lo com móveis de grife ou equipamentos eletrônicos de última geração como, por exemplo, TVs, Internet etc.

Embora sua arquitetura impressione, o hospital não é perfeito. Há problemas assim como os há em todos os outros hospitais, mas se uma comparação for feita, talvez os problemas sejam menores que em outras instituições.

\subsection{Hospital do Câncer de Barretos}

O Hospital do Câncer de Barretos é nacionalmente reconhecido pela sua qualidade no atendimento e tratamento contra o câncer e principalmente pelo envolvimento de personalidades famosas na parte financeira da instituição, tanto que os pavilhões do hospital todos recebem nomes de artistas e personalidades famosas como cantores de música sertaneja e políticos.

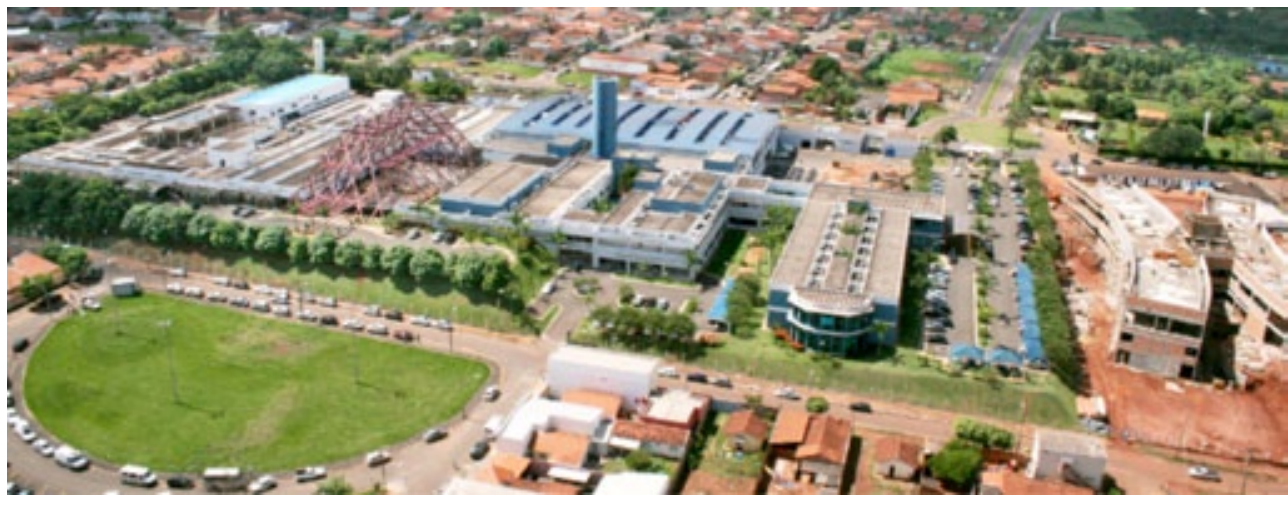

Foto aérea do

Hospital do Câncer

de Barretos

inte: acervo do

Hospital do Câncer

A instituição não é uma instituição pública. É uma instituição privada porém atende praticamente số usuários do Sistema Único de Saúde (SUS), praticamente 100\%, ou seja, em torno de 95,5\%.

Como é um hospital especializado, o fato de não atender a população em geral, em muito contribui para sua organização e funcionalidade, já que suas instalações físicas não têm aqueles problemas de superlotação, pacientes aguardando atendimento nos corredores etc., pois nem pronto atendimento geral existe no hospital. Os pacientes que lá se tratam, são encaminhados através de prefeituras e hospitais de todo o país, mas já vêm com um pré-diagnóstico que faz com que o trabalho de exames e triagem inicial seja facilitado e menos numeroso em termos de utentes a serem atendidos.

O tratamento realizado no Hospital do Câncer de Barretos é completo e abrange desde a triagem inicial, passando pelos exames, o tratamento específico com ou sem internação e até mesmo o tratamento estético. Tal tratamento, o estético, embora não tenha fins de cura, tem o objetivo de 
reabilitar o utente que necessitar para sua volta à vida social. Por exemplo, o hospital oferece (embora o SUS não cubra tais custos) próteses da face, permitindo que utentes possam ter um mínimo de qualidade estética ao concluir o tratamento. Claro que nos casos que tal tratamento se fizer necessário, como, por exemplo, nos casos de cânceres que acabam por comprometer uma parte estética da pessoa, como o nariz, a orelha, além de outras partes.

Outra ação importante desenvolvida pelo hospital é a prevenção. Ela visa prevenir efetivamente a doença ou ao menos conseguir que a descoberta de sua existência seja precoce de maneira a oferecer maior eficácia no tratamento. A prevenção acontece de duas maneiras: exames, palestras e procedimentos preventivos, que ocorrem no próprio hospital e através de unidades móveis com a mesma finalidade.

As instalações físicas existentes e com esta finalidade são recém inauguradas. Há um bloco funcional todo voltado para a prevenção que conta com consultórios, salas de exames como mamografia, ultrasonografia, etc. tudo com ambientação muito agradável e voltada para esta finalidade espeć́fica. Por exemplo, as gravuras que decoram os ambientes, em sua maioria trazem informações sobre a prevenção e sobre suas formas.

As fotos a seguir ilustram o que foi dito em relação aos ambientes e sua decoração em finalidade bem evidente:

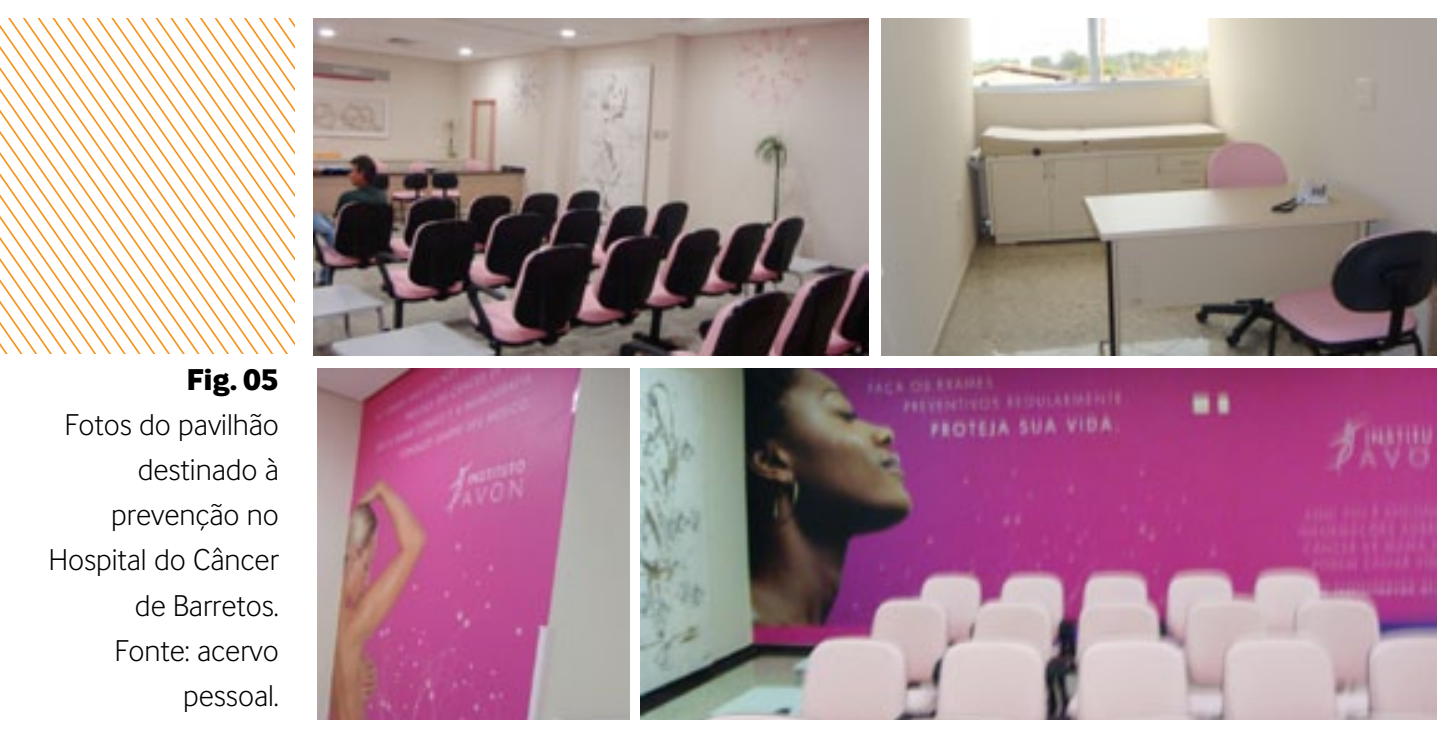

As unidades volantes consistem em vários ônibus que transportam as equipes volantes de prevenção, incluindo médicos, dentistas e enfermeiros. Esses veículos estão equipados com completos consultórios e salas de exame. Alguns inclusive transportam equipamentos sofisticados de exame preventivo como mamografias. Estas unidades circulam por praticamente todo o pais buscando em especial as comunidades que não têm acesso à estas iniciativas preventivas.

Assim como os pavilhões, os veículos também recebem nomes de artistas populares. Artistas que, além de colaborarem financeiramente com o programa, ajudam a tornar mais simpático e acessível o programa a tais comunidades.

A seguir fotos dos veículos utilizados.

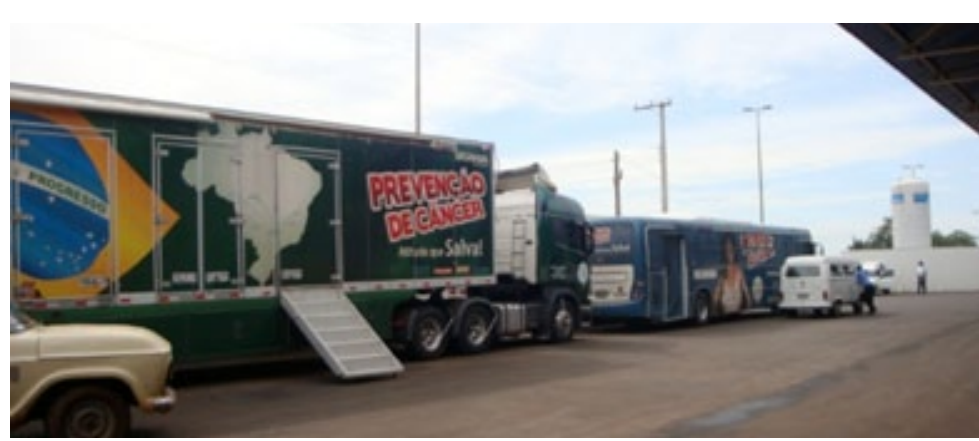

Fotos dos veículos utilizados

nas campanhas de

revenção contra o câncer comunidades carentes

de atendimento.

Fonte: acervo pessoal.

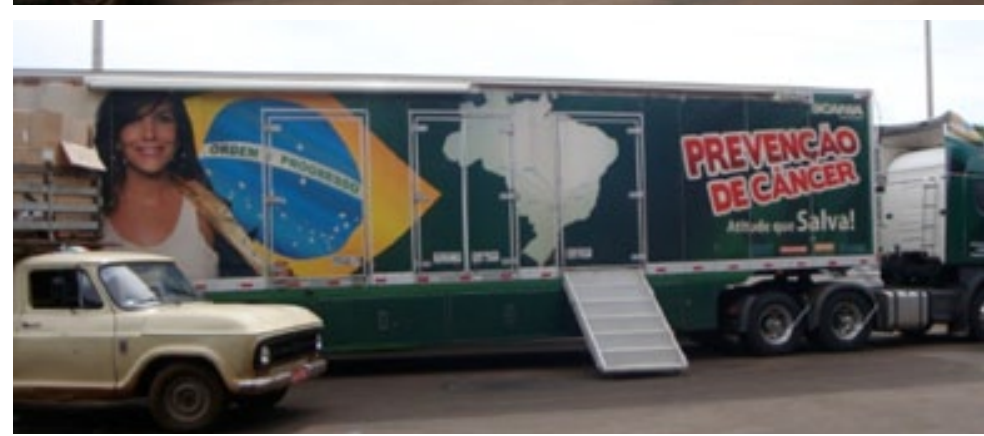

Equipe técnica do hospita:

Um dos fatores que faz com que a instituição seja referência e consequentemente tenha tal procura por seu tratamento, está na equipe técnica, em especial no corpo clínico formado pelos médicos do hospital que totalizam 180

A equipe médica tem obrigatoriamente que oferecer dedicação exclusiva e ter ao menos uma produção científica por ano. Para assegurar que esta equipe tenha interesse em permanecer no corpo clínico da instituição, a administração conta com três artifícios: status profisssional para quem é membro de tal equipe, garantido pela fato de o hospital ser referência nacional em sua especialidade; 
remuneração acima da média dos hospitais do país: e instalações que privilegiem tais profissionais a permanecerem mais tempo dentro da instituição, tais como bibliotecas e salas de estudo individual.

Com relação à remuneração, em conversa com um médico do corpo clínico, pôde-se apurar que tal remuneração é boa a ponto de os médicos não buscarem oportunidades fora da instituição. Em nenhum momento se falou em valores, mas referencialmente foi passado que se é remunerado muito acima da média, em valores superiores à remuneração oferecida em países da Europa, por exemplo. Como se sabe, tal argumento tem altíssimo poder de tornar tais profissionais fiéis a qualquer instituição.

Com relação às instalações que privilegiem estes profissionais, pode-se ver, ao se andar pelo hospital. o empenho da administração em tornar os espaços de convivio dos profissionais mais agradáveis. Uma das salas de conforto médico, por exemplo, tem decoração com mobiliário renomado e confortável, não que isso ofereça algum ganho ao ambiente, mas demonstra a preocupação da administração em garantir um diferencial. Tal ambiente oferece ainda serviço exclusivo de cafeteria e conta com equipamentos eletrônicos de última geração, como TVs de LCD, acesso à internet sem fio etc. Já na área destinada ao trabalho, pesquisa e estudo disponível aos profissionais, estes contam não somente com suas salas privativas mas também com uma agradável biblioteca, sala de estudo com disponibilidade de computadores para trabalho e acesso à internet, sala de estar climatizada e muito agradável e ainda um auditório para palestras e treinamentos.

A seguir, fotos dos ambientes citados.

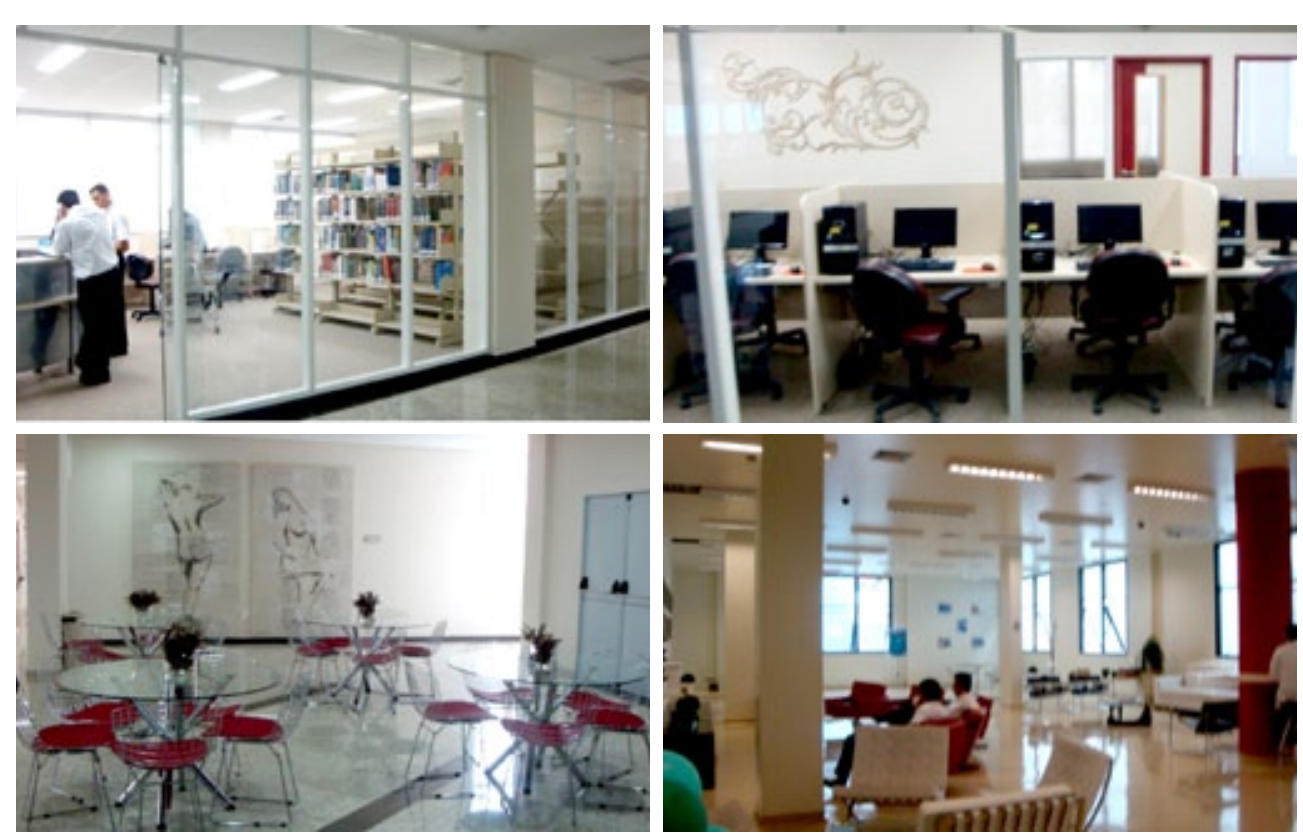

Situação financeira:

O sucesso da instituição se deve principalmente à gestão profissional e empreendedora de seu administrador. 0 provedor, é o filho do fundador da instituição, porém é administrador e não médico como eram seus pais.

Como a maioria das instituições de atendimento à saúde que oferecem atendimento ao sistema único de saúde (SUS), o Hospital do Câncer de Barretos passou por numerosas e graves crises financeiras. A última colocou a instituicão a ponto de findar seu atendimento. Foi neste momento que a administração passou das mãos do médico fundador para seu filho, administrador.

No momento em que iniciava o processo de fechamento do hospital, a instituição recebeu a visita de famosa dupla de música sertaneja: Chitãozinho e Xororó. Tal dupla ao conhecer as instalaç̃es ficou motivada a contribuir financeiramente com o hospital desde que ele não fechasse suas portas. Desde então, foi criado um show de música com renda destinada ao hospital, envolvendo outros astros da música sertaneja (o show Amigos) que durante vários anos foi realizado na festa do peão de Barretos. Tal ajuda financeira fez com que um novo ciclo de realizações se inicializasse. Mais, a divulgação de tal iniciativa fez com que outros astros e personalidades fizessem o mesmo. Por isso os pavilhões do hospital recebem nomes desses astros populares.

Pode-se pensar que o pavilhão Gugu Liberato ou o Sérgio Reis seja mantido por eles, o que não é verdade. O que dá "direito" a um artista ou personalidade ter seu nome oferecido a um pavilhão é na verdade, uma forma que a administração encontrou de homenagear as pessoas que em algum momento contribuíram com determinada quantia para com a instituição. Contribuição que nem é constante, nem na sua periodicidade nem no seu valor.

De fato, o atendimento preferencial ao SUS, que abrange praticamente 100\% dos utentes, mais especificamente 99,5\%, faz com que a instituição tenha um déficit mensal em torno de 3,5 milhões de reais. Inclusive, utentes que iniciam seu tratamento via convênios de saúde, ao longo de seu desenrolar, acabam, em função dos altos custos, geralmente negados pelos planos, finalizando seu tratamento pelo SUS, o que inclusive não implica em mudanças no tratamento, já que existe apenas um padrão de tratamento, que independe do sistema como o usuário ingressa nele,seja pelo SUS, por convênios ou paciente particular. 0 tratamento é o mesmo para todos.

Com um déficit destes, como é então que a instituição sobrevive, oferecendo qualidade no aspecto físico, do atendimento e técnico aos seus usuários? Segundo a administração, tal déficit não é coberto pelas contribuiç̃oes dos famosos que geralmente são direcionados para investimentos 
(atualmente o hospital conta com 10 obras em andamento simultaneamente) nem mesmo por ajudas governamentais. 0 tipo de ajuda financeira que realmente mantém a instituição em funcionamento desta maneira, é a ajuda da sociedade que, através de inúmeras formas de doação, mantém as finanças da instituição em dia. A seguir, como ilustração, uma parte de um informativo demonstrando as diversas formas de contribuição.

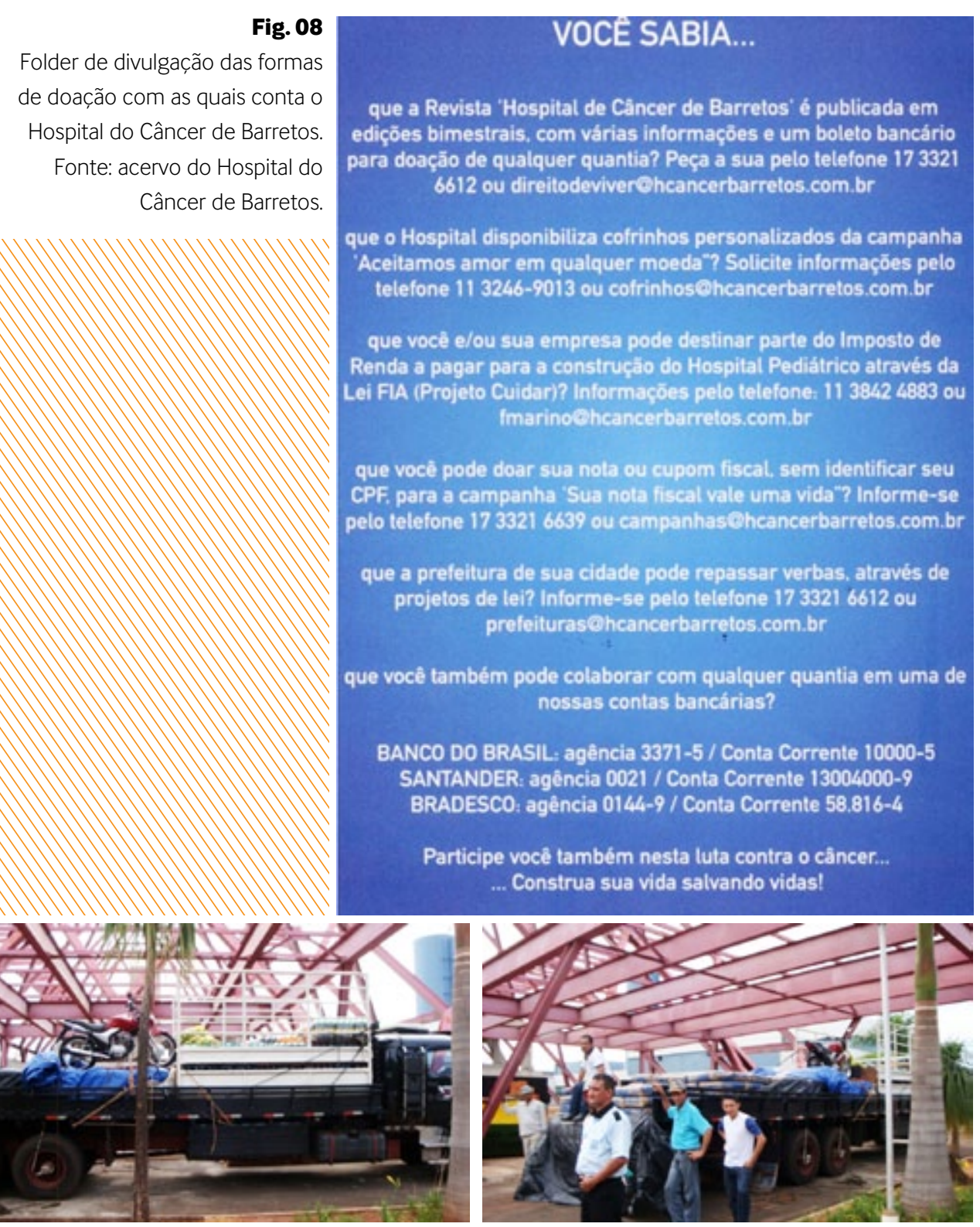

Descrição física e percepcõos

O Hospital do Câncer de Barretos é um hospital de pequeno porte. Tem atualmente 80 leitos.

Sua tipologia é caracterizada pela horizontalidade, embora não seja totalmente térreo e sua distribuição é do tipo pavilhonar. Há atualmente onze pavilhões destinados ao tratamento dos utentes, outros três destinados aos apoios, serviços e afins e um outro recém inaugurado voltado para fins de prevencão contra o câncer.

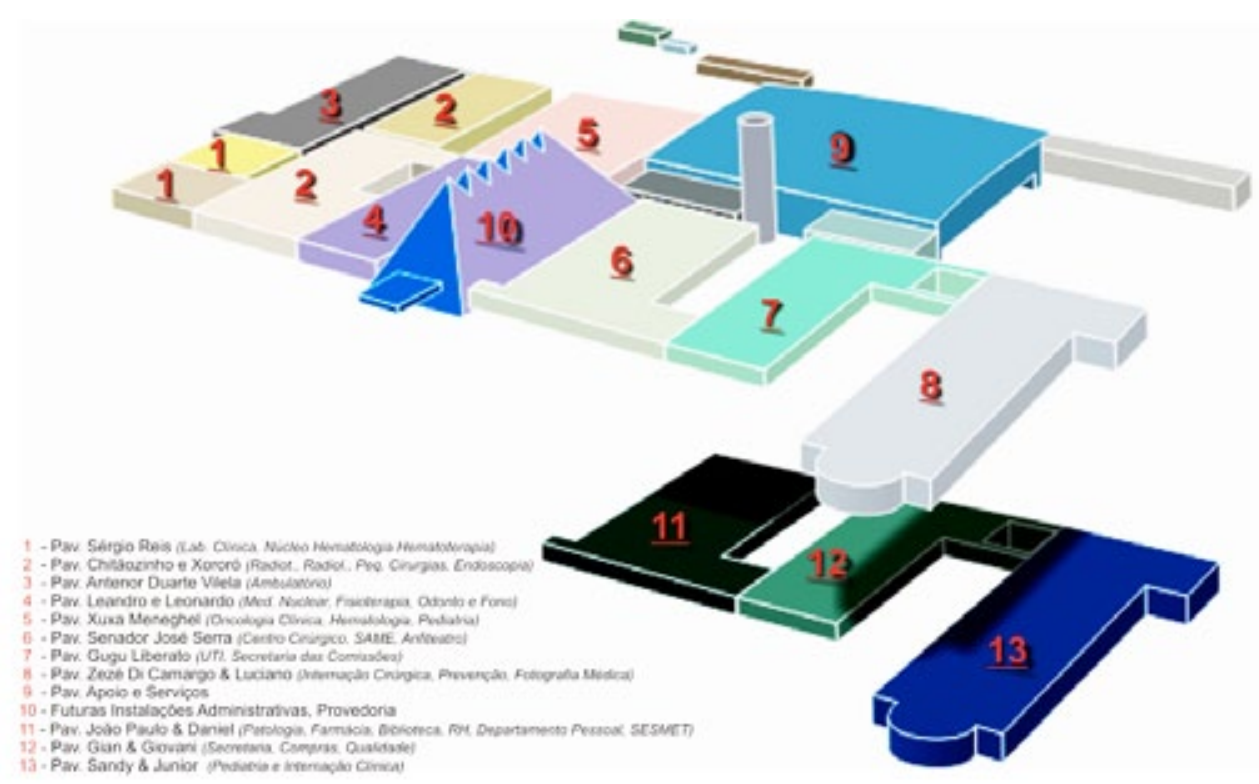

Fig. 10

mplantação

esquemática do

Hospital do Câncer

de Barretos.

Fonte: acervo do

Hospital do Câncer

de Barretos.

o Pavilhão 1 recebe o nome do Cantor Sérgio Reis e abriga o laboratório de análises clínicas o núcleo hematologia hematoterapia; o Pavilhão 2 recebe os nomes dos cantores Chitãozinho e Xororó e abriga o setor da radiologia, da radioterapia, complexo de pequenas cirurgias e instalações da endoscopia; o Pavilhão 3 recebe o nome de Antenor Duarte Vilela e abriga o ambulatório; 0 Pavilhão 4 recebe os nomes dos cantores Leandro e Leonardo e abriga a área destinada à medicina nuclear, fisioterapia, odontologia e fonoaudiologia; o Pavilhão 5 recebe o nome da apresentadora Xuxa Meneghel e abriga a oncologia clínica, a hematologia e a pediatria; o Pavilhão 6 recebe o nome do então Senador José Serra e abriga o centro cirúrgico e o anfiteatro; o Pavilhão 7 recebe o nome do apresentador Gugu Liberato e abriga a Unidade de Tratamento Intensivo (UTI) e a secretaria das comissões; o Pavilhão 8 recebe o nome dos cantores Zezé Di Camargo e Luciano e abriga a internacão cirúrgica e fotografia médica; o Pavilhão 11 recebe o nome dos cantores João Paulo e Daniel e abriga os setores de patologia, farmácia, biblioteca, RH e departamento pessoal; o Pavilhão 
12 recebe o nome dos cantores Gian e Giovani e abriga os setores de secretaria, compras e qualidade: e o Pavilhão 13 recebe o nome dos cantores Sandy e Júnior e é o pavilhão destinado às internações, tanto adulta quanto pediátrica.

Os pavilhões 9 e 10 são pavilhões de apoio. 09 abriga toda a central de apoio e serviços e o pavilhão 10, ainda em construção, abrigará as instalações administrativas e provedoria.

Não consta nesta implantação ainda o pavilhão recém inaugurado que é patrocinado inteiramente pela empresa Avon e que se destina exclusivamente à prevenção contra o câncer.

O crescimento do hospital parece ter acontecido de maneira desordenada, porém de forma racional. Não há uma confusão arquitetônica na implantação e nem mesmo uma grande diferenciação visual entre os pavilhões antigos e os novos. O que denuncia diferença entre eles é o material de acabamento utilizado nas diferentes etapas da construção, o que em nada compromete a qualidade dos ambientes nem ao menos incomoda os usuários.

O complexo todo, por onde se ande, é agradável e convidativo. Há a presença de paisagismo em praticamente toda sua implantação o que torna os ambientes bastante agradáveis.

A área destinada à permanência dos utentes, o setor das enfermarias (Pavilhão Sandy e Júnior) é bastante agradável. Embora arquitetonicamente não seja diferenciada, o fato de haver uma boa relação entre interior e exterior, a presença de paisagismo, a utilização adequada de cores, ter conforto térmico garantido - embora de maneira artificial - e ter uma decoração simples, porém muito agradável, traz os valores básicos que tornam este setor bastante confortável e confiável.

De maneira geral, os ambientes podem ser caracterizados pelo adjetivo feliz. São ambientes felizes e as pessoas que por eles circulam, geralmente acompanhantes ou mesmo utentes, irradiam felicidade e confiança. É uma sensação contagiante e impressionante, principalmente por se tratar de um hospital. Em geral, o ambiente não parece um ambiente hospitalar convencional. A arquitetura não é em nada genial, ela somente parece tratar cada detalhe com o devido valor e isso parece trazer qualidade aos ambientes.

Por exemplo, qualquer pessoa ao circular pelos corredores do complexo, sendo eles abertos ou fechados em função do seu uso, terá a sensação de estar circulando por varandas. Neles sempre se tem luz natural em abundância, conforto térmico, presença de paisagismo, relação prazerosa com o exterior, entre outros fatores. Tudo isso faz com que estes espaços deixem de parecer corredores e pareçam grandes varandas e neles os utentes não parecem circular, mas passear.
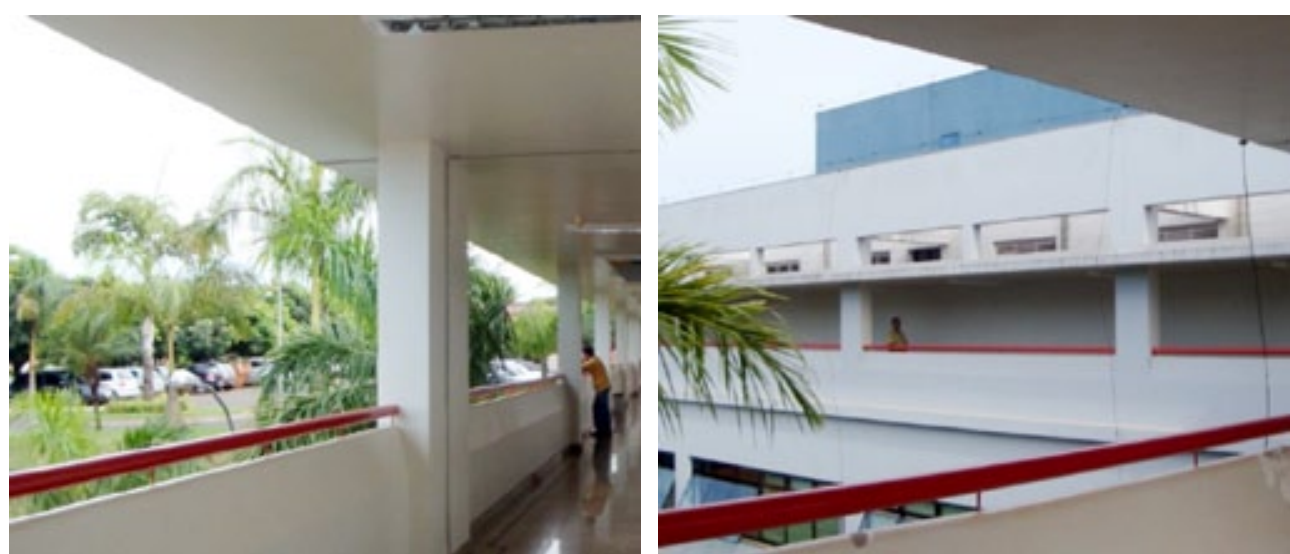

tos demonstrativas

das varandas de

circulação periférica

Hospital do Câncer

Barretos.

Fite: acervo pessoal.

Obviamente nem tudo é perfeito. Existem sim setores com grande quantidade de pessoas, como o ambulatório, onde praticamente se faz a triagem inicial dos utentes, o que inclusive gera filas de espera e pessoas incomodadas. Também existem os tradicionais corredores, mas estes em geral são destinados à circulação técnica dos profissionais, aos serviços de apoio etc. Obviamente o hospital não é perfeito, mas pode-se concluir que ele oferece muito mais qualidade que falta dela, principalmente naqueles ambientes de maior permanência e circulação dos utentes e familiares. Certamente en muito a arquitetura consegue contribuir na qualidade de todos os ambientes destinado aos seus usuários. A todos eles.
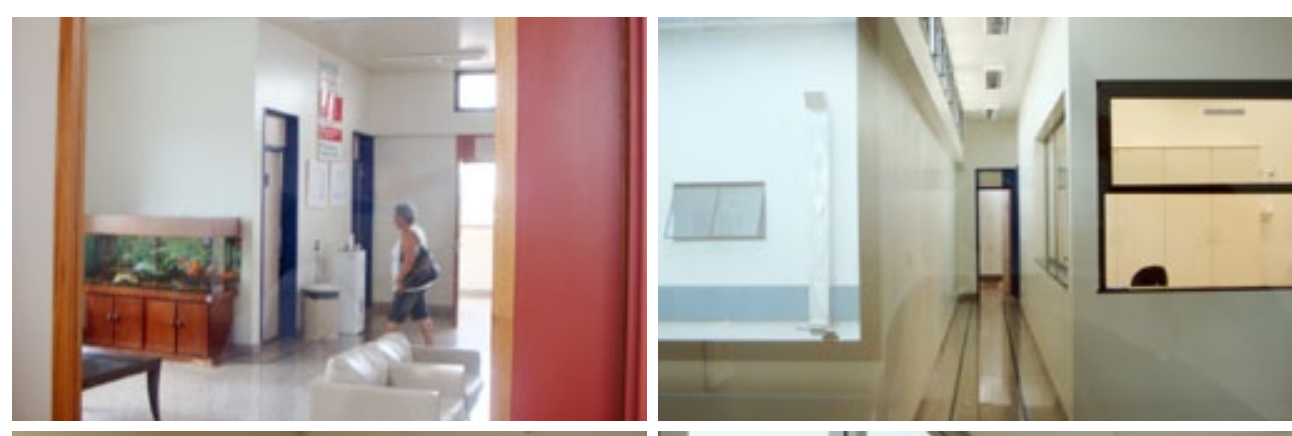

Fotos ilustrativas

dos ambientes de uso comum do Hospital do Câncer de Barretos.Fonte: acervo pessoal.

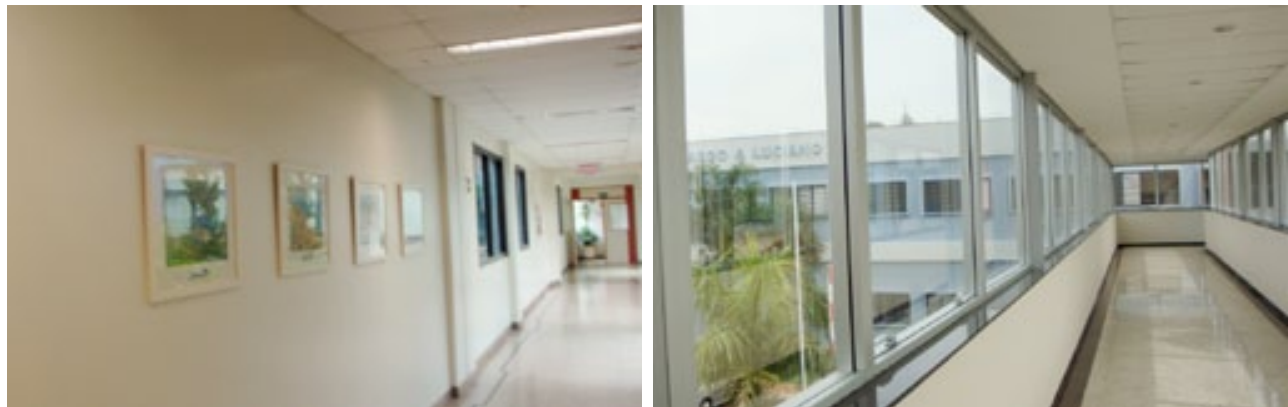




\subsection{Santa Casa de Porto Alegre}

A Santa Casa de Porto Alegre é uma instituição que existe desde 1826 e desde sua inauguração até hoje, prima pelo atendimento aos excluídos. No início, os excluídos eram os indigentes, os escravos urbanos abandonados etc. e atualmente, pode se entender por exclú́dos, aqueles que não têm a condição financeira para garantir seu atendimento de maneira particular ou mesmo através de um plano de saúde, ou seja, a população assistida pelo SUS.

Até as décadas de 80/90 do século passado, a instituição atendia 95\% de seus usuários pelo sistema do SUS. Atualmente, tal parcela concentra-se em $60 \%$, o que ainda é um índice bastante alto e mais adiante vamos entender o porquê desta mudança de percentual e suas consequências.

Descrição física:

A Santa Casa, hoje, é constituída por um complexo de sete hospitais totalizando aproximadamente 130.000 metros quadrados de área construída: o Hospital Santa Clara, o Hospital São Francisco, o Hospital São José, o Pavilhão Pereira Filho, o Hospital Dom Vicente Scherer, o Hospital da Criança Santo Antônio e o Hospital Santa Rita. Disponibiliza um total de 1.040 leitos, Unidades de Terapia Intensiva (UTIS) e centros cirúrgicos em todos os hospitais. Deste total de leitos, tendo como parâmetro todo o complexo, $60 \%$ deles são destinados ao atendimento aos usuários do SUS. Em alguns hospitais tal índice é maior ( $85 \%$ no Hospital Santa Clara, por exemplo) e em outros menor (30\% no Pavilhão Pereira Filho, por exemplo).

\section{Fig. 13} Implantação esquemátic do complexo da Santa Casa de Porto Alegre. Fonte: acervo da Santa Casa de Porto Alegre

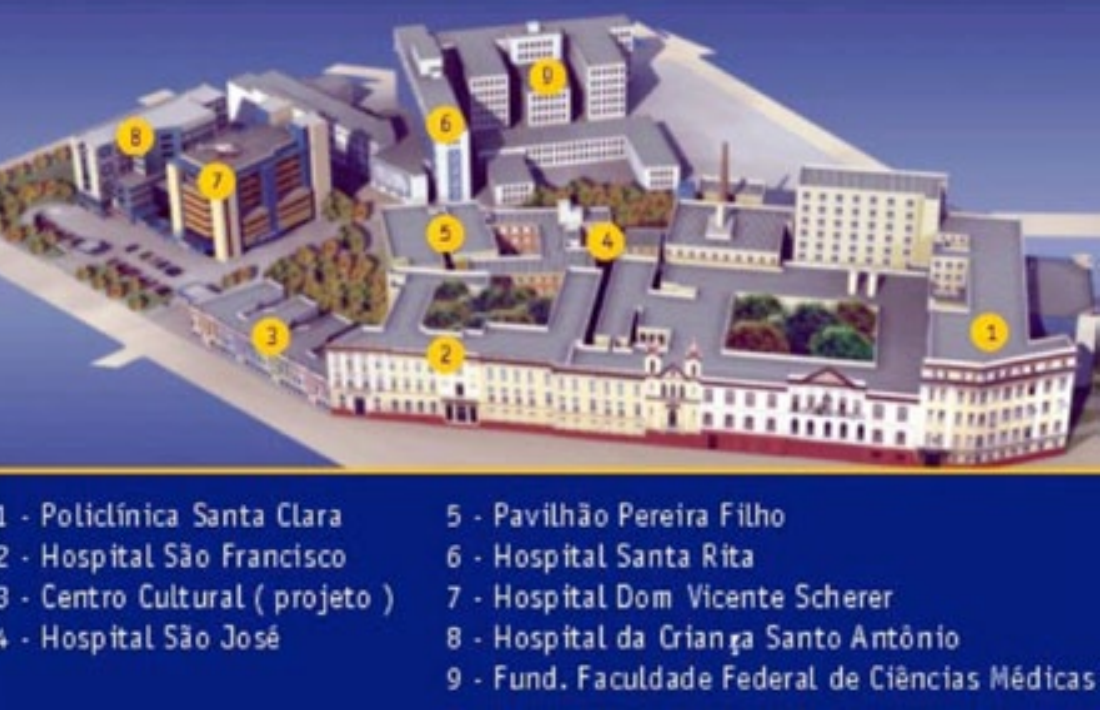

A construção iniciou-se pelo Hospital Santa Clara (1), seguida pelo Hospital São Francisco (2), Hospital São José (4), Pavilhão Pereira Filho (5), Hospital Santa Rita (6), Hospital da Criança Santo Antônio (8) e Hospital Don Vicente Scherer (7), conforme mostra a figura acima.

O Hospital Santa Clara foi inaugurado em 1826 e é o grande hospital geral de adultos do complexo. Suas atividades abrangem a assistência, o ensino e a pesquisa; seu atendimento abrange urgência, emergência, consultas eletivas, exames, cirurgias, internação e intensivismo. Atualmente, o Hospital Santa Clara possui 372 leitos (85\% destinados ao atendimento SUS) sendo 38 destinados à Unidade de Tratamento Intensivo (UTI) e engloba 28 especialidades com foco na clínica médica, cirúrgica e na área materno-infantil.

O Hospital São Francisco foi inaugurado em 1930 e sua especialidade é cardiovascular e cirurgias de grande porte. Suas atividades abrangem tanto a assistência quanto o ensino e a pesquisa; seu atendimento abrande consultas eletivas, exames, cirurgias, internação e intensivismo. Suas instalaç̃̃es contam com 93 leitos (sendo 30\% deles destinados do SUS) incluindo os 20 destinados à Unidade de Tratamento Intensivo (UTI)

O Hospital São José foi inaugurado em 1946 e sua especialidade é neurocirurgia e neurologia Suas atividades abrangem a assistência, o ensino e a pesquisa; seu atendimento abrange consulta eletiva, exames, cirurgias, internação e intensivismo. Suas instalações contam com 80 leitos (40\% destinados ao atendimento SUS) incluindo os 13 da Unidade de Tratamento Intensivo (UTI).

O Pavilhão Pereira Filho foi inaugurado em 1965 e sua especialidade é pneumologia e cirurgia torácica. Suas atividades abrangem a assistência, o ensino e a pesquisa e seu atendimento abrange consultas eletivas, exames, cirurgias, internação e intensivismo. Suas instalações abrangem 80 leitos (30\% destinados ao SUS) incluindo os 12 leitos destinados à Unidade de Tratamento Intensivo (UTI).

O Hospital Santa Rita foi inaugurado em 1967 e incorporado ao complexo da Santa Casa em 1989. Sua especialidade é a oncologia, suas atividades abrangem a assistência, o ensino, a pesquisa, a prevenção e a educação. Seu atendimento abrange as consultas eletivas, os serviços de diagnósticos e tratamento, as cirurgias, internações e tratamento intensivo. Atualmente conta com 178 leitos (40\% destinados ao atendimento SUS) incluindo os 10 leitos da Unidade de Tratamento Intensivo (UTI),

O Hospital da Criança Santo Antônio foi inaugurado em 1953, mas até o ano de 2002 funcionava 
em instalação separada do complexo da Santa Casa. Neste ano então, suas novas instalaç̃̃es junto ao complexo foram concluídas e atualmente ele está funcionando junto aos demais hospitais. Sua especialidade, como o próprio nome indica, é pediatria geral e especialidades, o que torna esta unidade uma unidade de alta complexidade assim como as demais. Suas atividades abrangem a assistência, o ensino e a pesquisa; seu atendimento abrange urgências, emergências, consultas eletivas, exames, cirurgias, internação e intensivismo. Possui 173 leitos (60\% destinados ao SUS) incluindo as 25 Unidades de Tratamento Intensivo (UTI).

O Hospital Don Vicente Scherer foi inaugurado em 2002. Sua especialidade abrange centro de transplantes, centro cirúrgico ambulatorial, centro de imagem, centro integrado de emergências médicas e laboratório de imunologia de transplantes. Suas atividades englobam a assistência, o ensino e a pesquisa e o atendimento abrange urgência, emergência, consultas eletivas, serviços de diagnóstico e tratamento, cirurgias, internação e intensivismo. Possui 64 leitos (60\% deles destinado ao SUS) incluindo 11 Unidades de Tratamento Intensivo (UTI).

De maneira esquemática, pode-se entender a implantação física do complexo como um modelo funcional orbital, onde os hospitais todos centralizam seus serviços de apoio enquanto se comunicam entre si, conforme busca-se mostrar no esquema a seguir.

Fig. 14

\section{Figura llustrativa do}

sistema funcional

orbital do complexo

da Santa Casa.

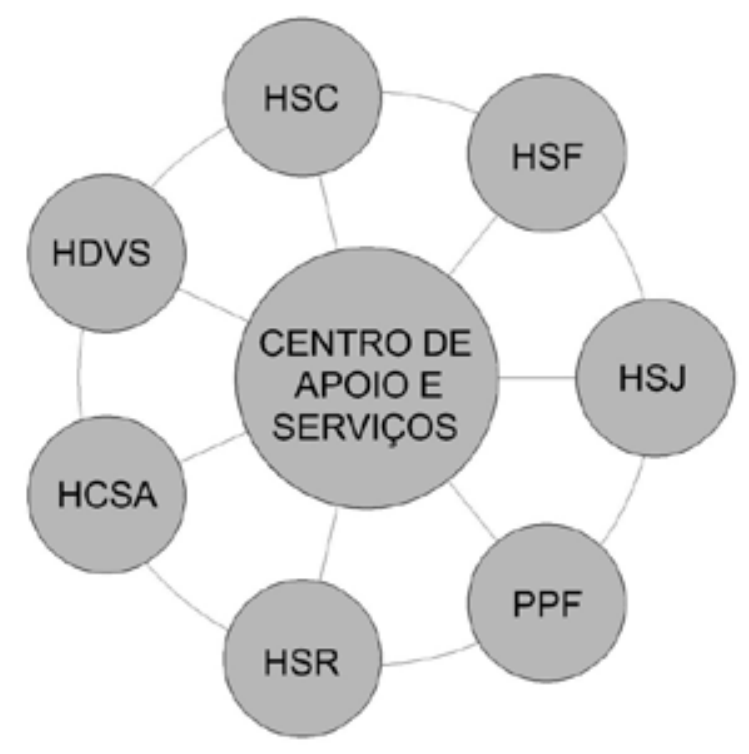

Situação financeira:

Para se entender a atual situação da Santa Casa de Porto Alegre, vamos buscar em sua história os motivos que fazem desta instituição o exemplo de sucesso tanto técnico quanto financeiro que é hoje.

A instituição não é um hospital público. É uma instituição privada com fins filantrópicos: uma fundação. Ela tem este modelo administrativo desde sua instituição.

Ao longo de seus dois séculos de existência, a Santa Casa passou por inúmeras crises que vieram se agravando e se tornando mais frequentes com o passar dos tempos até que na década de 1980 teve seu momento de maior dificuldade chegando inclusive a quase fechar suas portas e findar seu atendimento. Naquela época, a instituicão atendia praticamente só o sistema público de saúde ( $95 \%$ dos atendimentos) e tanto a baixa remuneração quanto as dificuldades impostas pelos planos de repasse de verbas públicas incoerentes com a situação real pela qual passava o país, com altos índices de inflação, colocaram a instituição em situação financeira bastante grave.

O então provedor, Dom Vicente Scherer, utilizou-se de uma providencia bastante comum na época que foi a busca de recursos junto ao governo do Estado. Foi então, frente à esta crise tão grave, que o governador do Estado do Rio Grande do Sul, Jair de Oliveira Soares, em inédita atitude colocou ao provedor que a ajuda financeira aconteceria se, a Santa Casa passasse por um processo de mudanças administrativas que visassem a profissionalização da administração visando colocar a instituição como uma instituição voltada para obter resultados e consequentemente conseguir sua independência e auto-suficiência financeira.

Foi neste momento que a Santa Casa de Porto Alegre iniciou um grande processo de mudanças que culminou em grande revitalização de toda a instituição e seu processo administrativo vigente até os dias de hoje como grande referência de sucesso

Vale salientar que a Santa Casa, desde seu inicio de funcionamento até hoje, sempre primou pela alta qualidade técnica e de atendimento e que, mesmo nos momentos de maior dificuldade, tal qualidade nunca fora deixada de lado. Outro motivo que ajudou na sua recuperação, pois grande parte do sucesso atingido, deve-se também à comoção social que muito ajudou e ajuda até hoje a instituição. Tal comoção não existiria se a população não reconhecesse sua qualidade e necessidade.

Com o novo modelo administrativo em vigor, a partir de então, a Santa Casa passa a ter uma 
Uma das grandes intervenções que ajudaram na recuperação, foi a visão de qualificar e ampliar o atendimento à população através de atendimentos particulares e convênios. Neste momento, de certa maneira, parou-se de investir no grande hospital geral existente e passou-se a investir nos novos hospitais especializados como o hospital especializado em transplantes, do câncer, de pediatria, de pneumologia, de cardiologia e de neurologia. É a visão de que estes hospitais todos voltados para fins específicos e visando maior atendimento particular e de convênios, que visavam garantir maior rentabilidade ao complexo e assim, de certa maneira subsidiar os altos custos do hospital geral de atendimento SUS. Foi o que aconteceu na prática. Atualmente, todo o complexo deixou de atender o índice de $95 \%$ dos usuários do SUS e passou a atender o índice de $60 \%$. Vale salientar que em números reais, o atendimento não diminuiu, o que diminuiu foi o percentual um função do aumento do atendimento.

percentual de atendimento SUS de 60\% representa 30\% do faturamento e esta defasagem é que é compensada pelos atendimentos particulares. Foi esta a alternativa encontrada para se viabilizar e manter o atendimento à população que é assistida pelo SUS sem, em momento algum, se diminuir a quantidade ou a qualidade do atendimento.

Como o grande montante dos investimentos foi destinado às novas instalações, o Hospital Santa Clara, pioneiro e geral acabou por ter seu processo de atualização deixado sem segundo plano. Atualmente, com todo o complexo em total funcionamento, é o momento de recuperação e ampliação tanto física quanto tecnológico do Hospital Santa Clara. Em função disso, encontra-se em vigor uma campanha junto à população, empresários interessados e ao governo federal que visa angariar fundos para tal investimento. Para se atender a todas as necessidades levantadas, busca-se hoje o montante de aproximadamente 65 milhões de reais que serão divididos em 5 grande etapas que passam desde adequação e atualização das instalações físicas, por modernização dos equipamentos e das tecnologias até construção de novos espaços (ampliação física).

Estratégia administrativa

De maneira resumida, em entrevista com membros do departamento administrativo, pode-se concluir que a visão estratégica se coloca da seguinte maneira:

Qualificação e ampliação do atendimento: situação que se consolida com a instalação dos hospitais especializados que colaboram para o equilíbrio financeiro gerado pelo déficit do atendimento ao SUS.
- Plano de qualidade total: plano este que vem sendo buscado e atingido desde a grande reforma administrativa. Aqui, vale ilustrar tal situação com o fato de os utentes atendidos pelo sistema SUS, através de pesquisa de satisfação, colocarem a instituição entre as mais bem avaliadas do Estado. Tal situação, não somente compreende qualidade ao atendimento cada vez maior como também, através de incentivos do governo, o que melhora o valor das verbas públicas.

- Atividades acessórias: algumas atividades paralelas ao hospital, tais como exploração do cemitério, cafeterias e estacionamento entre outras atividades, têm se revelado altamente restáveis pois, apesar de seus faturamentos representarem de 3 a $4 \%$ do total, na realidade representam até 50\% do resultado. Desta maneira, cada vez mais se investe em tais serviços.

- Auto-suficiência dos serviços: enquanto em grande parte dos setores costuma-se ouvir que a terceirização de alguns setores ajuda na diminuição de gastos e consequente aumento de rentabilidade, a administração da Santa Casa entende o contrário. Entende que tais serviços, se forem bem geridos tornam-se lucrativos e rentáveis. Por exemplo, os setores de diagnósticos (laboratórios, imagens, etc.) de consultórios e até mesmo a gestão de obras no caso da instituição são feitos pela própria Santa Casa e revelam-se atividades lucrativas.

- Ganho de escala: como o complexo movimenta grandes montantes de material, de compras, de serviços, etc. a administração busca no ganho de escala melhorar seu desempenho financeiro.

- Trabalhar a marca: a marca Santa Casa de Porto Alegre é de forte expressão principalmente no Estado do Rio Grande do Sul tanto pela fama da qualidade de seus serviços prestados, quanto pela idoneidade da instituição. Desta maneira, trata-se a marca como um diferencial. Um exemplo prático é na contratação do corpo clínico pois tal situação torna mais viável a contratação de profissionais (médicos, enfermeiros, etc.) pois há um interesse em trabalhar na instituição que não somente o financeiro.

- Qualidade da equipe técnica: sabe-se que a qualidade da equipe técnica é responsável por grande parte do sucesso de qualquer instituição de saúde. 0 motivo que faz com que a equipe técnica da Santa Casa de Porto Alegre seja referência regional e até mesmo nacional em algumas especialidades pode ser entendido por vários motivos que não somente o financeiro Um deles é o vínculo com a universidade e consequente ganho de conhecimento e atualização constante das teorias, técnicas e procedimentos técnicos. Além disso, para a equipe médica em especial, a Santa Casa de Porto Alegre é referência regional, ou seja, pertencer ao corpo clínico da Santa Casa de Porto Alegre é sinônimo de status profissional. Vale colocar que a equipe médica totaliza 2200 profissionais entre contratados e funcionários. 
Percepcão da visita:

Nitidamente, conforme os tempos foram passando nesses dois séculos de existência da Santa Casa de Porto Alegre, a característica das construções também foi se modificando. No Hospital Santa Clara, no Hospital São Francisco, no Hospital São José, Pavilhão Pereira Filho e Hospital Santa Rita, nitidamente temos o padrão de construção do tipo pavilhonar. Já os dois edifícios mais novos, do Hospital da Criança Santo Antônio e o Hospital Dom Vicente Scherer, têm a característica do monobloco vertical.

Também fica clara a percepção que os hospitais de característica pavilhonar, inclusive por serem mais antigos, surgiram e se desenvolveram de maneira menos planejada. A implantação deles é uma grande confusão arquitetônica onde hora se tem espaço vazio, hora não. Tudo é muito confuso. Embora de maneira aparentemente intuitiva, buscam-se alternativas para minimizar tal desconforto imposto principalmente ao utente através da utilização de paisagismo onde é possível. Pode-se concluir que por este aspecto, o complexo se torna mais agradável para os acompanhantes e equipe médica que necessariamente para o utente. Quem frequenta as áreas comuns, corredores, salas de espera, cafeterias ou mesmo passeia entre os prédios, sempre tem contato com praças, temperatura confortável. Pode-se dizer até mesmo que é agradável passear pelo complexo. Para o utente que pode "passear" pelo complexo, pode-se concluir que o passeio é agradável. 0 mesmo não se pode dizer das enfermarias, neste aspecto. Analisandose o mobiliário, as cores utilizadas ou mesmo a iluminação artificial adotada, conclui-se que tudo soma em qualidade e agradabilidade ao utente. Também há segurança em qualquer dependência do complexo. Mas na questão de conforto térmico, ventilação e iluminação natural, presença de verde, relação interior/exterior, nas enfermarias sua função é nula, ou seja, em nada contribuem para o ambiente neste aspecto. Em algumas enfermarias, há uma excelente intenção de oferecer um conforto diferenciado com a utilização de varandas externas, mas tal intenção se anula em função do desconforto térmico das varandas desprotegidas e mal planejadas do ponto de vista de insolação; quando se está nas varandas, pouco de verde natural se vê; o que se vê na verdade são os outros prédios do complexo, o que em nada é agradável. Muitas dessas enfermarias inclusive acabam passando parte do tempo semi fechadas para garantir conforto térmico ou até mesmo certa privacidade.

Analisando desta maneira, nitidamente se conclui que os novos prédios, com tipologia monobloco vertical, no caso da Santa Casa de Porto Alegre são muito mais eficientes. Já que projetualmente se buscou garantir conforto térmico independente do clima, através de climatização artificial, os mecanismos de controle de luz natural são bastante eficientes através de esquadrias atuais e o mesmo tratamento no que se refere à utilização de cores, mobiliário, iluminação artificial, etc. é adotado, ou seja, ao contrário do que se pode imaginar, estes hospitais têm toda a vantagem que os outros mais antigos não têm e de certa forma compensam e corrigem o que de ruim hã neles.

É possível se afirmar que tais edifícios são agradáveis aos utentes e seus acompanhantes. Há presença de iluminação natural, embora o edifício seja climatizado, presença de paisagismo, embora esteja presente mais nas áreas comuns e de circulação e desta forma há uma boa relacão entre interior e exterior. Um elemento curioso traz grande qualidade ao complexo: hâ construída, certamente com a intenção de facilitar as circulações, uma grande passarela sobre pilares que liga todos os edifícios. Tal passarela encontra-se constantemente acima do níve do solo e é totalmente envidraçada. Como comentado, o utente que tem a possibilidade de "passear" pelo hospital, e isso é relativamente comum, tem sempre um grato prazer, o que muito contribui em sua recuperação. Para os acompanhantes, que circulam com mais frequência, tais passarelas são elementos muito interessantes pois fazem de um caminhar pelo complexo um passeio agradável, minimizando aquela sensação de monotonia geralmente encontrada nos hospitais com longos corredores e saguões.

Outro fator, que chama muito a atenção, é o fato de praticamente todos os ambientes receberem o mesmo tratamento, independentemente de serem destinados ao SUS ou aos convênios ou particulares. Tal situação se torna bastante nítida pois, dificilmente se identifica se uma ala ou andar é voltado para um ou outro atendimento. Pode-se perceber que, a diferença encontra-se na maior ou menor quantidade de leitos por enfermaria conforme a situação do utente. Pode-se ter um, dois ou três leitos na enfermaria em função do plano de saúde ou pagamento particular.

Ao se buscar por acomodaç̃oes específicas para a equipe médica ou de enfermagem, nota-se que não há ambientes projetados especificamente para eles. A princípio pode parecer que nenhuma atenção é dada a eles, mas, conforme se entende o funcionamento e o cotidiano do complexo se entende o porquê desta situação. Tais profissionais circulam constantemente pelo complexo e frequentam as áreas comuns, tais como os café, as lanchonetes, as praças, etc. Tais ambientes são bastante agradáveis e tal fato se confirma pois nota-se que todos estes ambientes, geralmente bastante confortáveis estão sempre cheios ou de profissionais, ou de acompanhantes e muitas vezes dos próprios utentes. Há uma sensação de bem-estar geral ao se andar pelo complexo. Não há luxo, em nenhum ambiente visitado se notou uma preocupação com isto.

Fato inegável é a cordialidade e a amabilidade de todo e qualquer funcionário e mesmo de familiares dos utentes. Lá, todos são muito bem recebidos e tratados. Isto demonstra não se tratar de nenhum tipo de treinamento especial ou mesmo intencional: é cultural local e isso em 
muito contribui para tornar os ambientes mais agradáveis.

Resumidamente, não há nenhuma preocupação com a humanização dos ambientes com relação à arquitetura. Nota-se sim que os ambientes são agradáveis, transmitem confiança e, nitidamente se busca qualidade ao ambiente. Qualidade esta que se traduz em humanização pois neste caso, temos o exemplo prático de que os requisitos básicos tornam o ambiente mais agradável. Não temos neste caso um grande exemplo arquitetônico nem mesmo uma arquitetura preocupada com este aspecto. Vê-se sim que uma arquitetura com um mínimo de qualidade pelo menos traz elementos que se somam e naturalmente melhoram a qualidade do ambiente no quesito humanização.

\subsection{Santa Casa de São João da Boa Vista Dona Carolina Malheiros}

A Santa Casa Dona Carolina Malheiros, até 10 anos atrás era o único hospital da cidade e assim como a maioria das Santas Casas, sua história se confunde com a história da cidade. Embora isso venha se modificando, a maioria dos médicos da cidade tem ou teve nela seu apoio de atendimento e isso cria uma estreita relação entre Santa Casa, médicos e usuários.

A Santa Casa Dona Carolina Malheiros não é um hospital público, mas tem no atendimento público uma de suas principais atuações, pois 70\% de suas internações são destinadas ao

\section{Fig. 15}

Foto aérea da Santa Casa Dona Carolina Malheiros com a construção original. Fonte: acervo da Santa Casa Dona Carolina Malheiros.

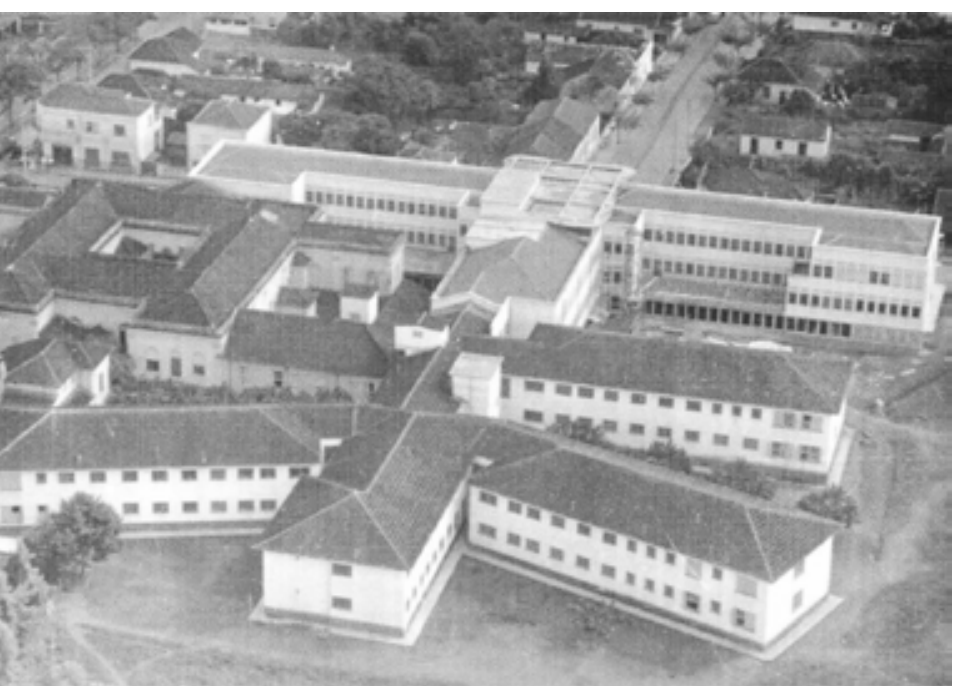

público do Sistema Único de Saúde (SUS). Por ser um hospital com 156 leitos, centro cirúrgico, Unidade de Tratamento Intensivo (UTI), maternidade e prestar serviços ambulatoriais geral, oncologia, hemodiálise, radiologia, análises clínico-patológicas, fisioterapia entre outras, a Santa Casa Carolina Malheiros torna-se um centro regional pelo fato de atender as cidades adjacentes a São João da Boa Vista como Aguaí, Vargem Grande do Sul, Espírito Santo do Pinhal, Águas da Prata, Santo Antônio do Jardim, etc. Sua localização estratégica permite inclusive remoção de utentes com facilidade para grandes centros como Campinas e Ribeirão Preto.

É um hospital de tipologia predominantemente horizontal, pavilhonar e que nos seus 110 anos de existência, praticamente não teve grandes ampliações e sim passou por inúmeras reformas de adequação. Reformas estas, inclusive que aconteceram tardiamente o que fez com que a Santa Casa Carolina Malheiros perdesse um pouco de sua credibilidade técnica perante a população

Situação financeira

Assim como a maioria das Santas Casas, que tem grande parcela de seu atendimento voltado para os usuários do Sistema Único de Saúde (SUS), a Santa Casa Carolina Malheiros veio ao longo de sua existência passando por inúmeras e consecutivas crises financeiras que por diversas vezes a colocaram em ponto de fechar suas portas.

Sua provedoria, por muitos anos foi ocupada por médicos, geralmente membros do corpo clínico, e sua administração era feita de maneira não profissional, o que somente fazia com que as crises financeiras se agravassem cada vez mais inclusive colocando a instituição em situações de incapacidade de manutenção e investimento que a fizeram ter um declínio em sua qualidade de atendimento oferecida.

Para solucionar tal situação cada vez mais grave com o passar dos anos, há perto de 10 anos. iniciou-se um processo de profissionalização da administração. Empresários experientes e bem sucedidos da cidade se envolveram com a instituição, investiram tempo e dinheiro nela e iniciaram um novo processo de terceirização da administração. Uma empresa especializada na área de administração hospitalar foi contratada e até hoje o cargo de provedor é alternadamente ocupado por algum empresário da cidade, sempre de maneira não remunerada.

Ao contrário da Santa Casa de Porto Alegre, que optou por não terceirizar a maioria dos serviços prestados, a Santa Casa Carolina Malheiros praticamente terceirizou todos os procedimentos. Tal situação ocorreu, não necessariamente por necessidade financeira, mas porque foi a maneira encontrada pela administração para vencer a barreira do corporativismo médico existente na 
cidade e consequentemente existente na Santa Casa, onde muito dificilmente se admitia um novo médico no corpo clínico ou mesmo dificilmente alguma empresa prestadora de serviço conseguia fechar algum contrato com a instituição.

Ultrapassada esta barreira, novas equipes técnicas foram contratadas para diversos procedimentos e setores, como radiologia, loboratório de análises clínicas, ambulatório, fisioterapia, hemodiálise, oncologia, etc. Até mesmo a equipe médica atuante hoje na Santa Casa é totalmente terceirizada. Não há atualmente funcionários médicos na instituição a não ser os pertencentes ao corpo clínico que por ela são responsáveis.

Talvez não seja essa a maneira mais rentável de se administrar a instituição, mas foi esta iniciativa que permitiu a instituição superar esta barreira existente que impedia sua sobrevivência, manutenção e crescimento.

Atualmente, a Santa Casa Dona Carolina Malheiros tem suas finanças equilibradas. O déficit gerado pelos 70\% de atendimentos voltados ao Sistema Único de Saúde (SUS) é muito baixo para o porte da instituição, aproximadamente 130.000 reais mensais, valor este facilmente absorvido pelo atendimento aos convênios e particulares.

Com as finanças em dia, a Santa Casa consegue atualmente garantir sua sobrevivência e manutenção mas, não há disponibilidade de verbas para investimentos. A saída para se conseguir fazer investimentos tanto nas instalações físicas quanto na atualização técnica foi se fazer campanhas para angariar fundos para tais finalidades. Houve nos últimos anos campanhas junto à população e também junto às empresas locais, todas elas muito bem sucedidas e que permitiram à Santa Casa Carolina Malheiros voltar a investir em seu crescimento e qualidade a oferecer aos seus usuários.

O informativo ao lado foi amplamente divulgado na cidade quando os primeiros resultados começaram a ser vistos.

Descrição física e percepções

A Santa Casa Dona Carolina Malheiros esta passando atualmente por um processo de revitalização de suas estruturas físicas. Revitalização porque durante longos anos ficou sem atualização e sua recuperação atual é mais que uma simples reforma. Obviamente também se aproveita o momento para se fazer adaptações aos tempos atuais, como a que esta ocorrendo nas enfermarias, onde antes não haviam banheiros.

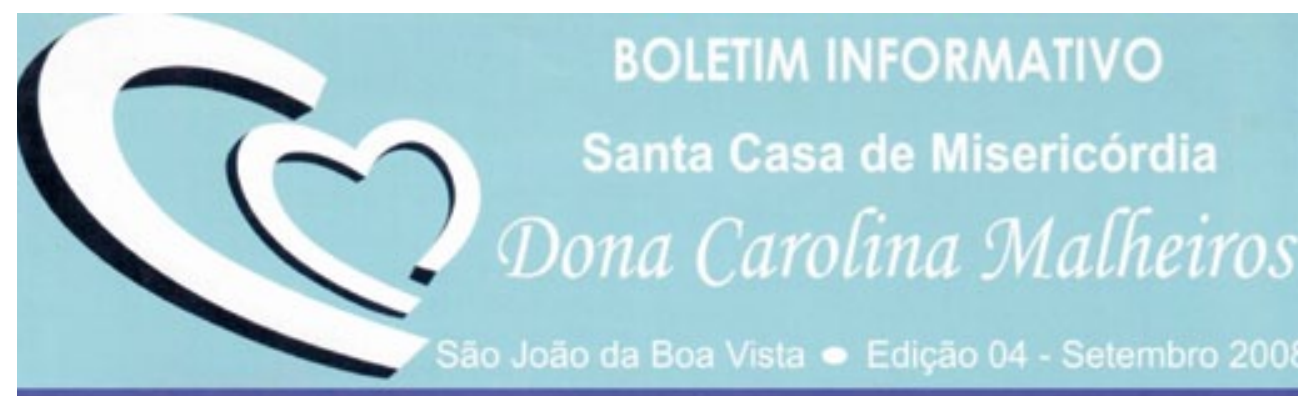

\section{Nem parece SUS...}

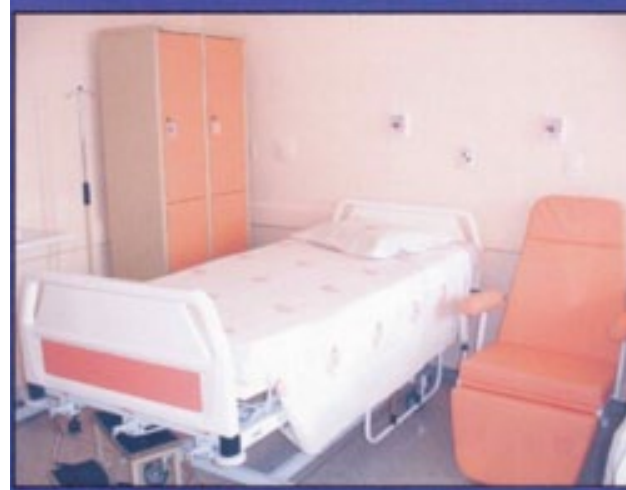

Enfermaria

Feminina do SUS

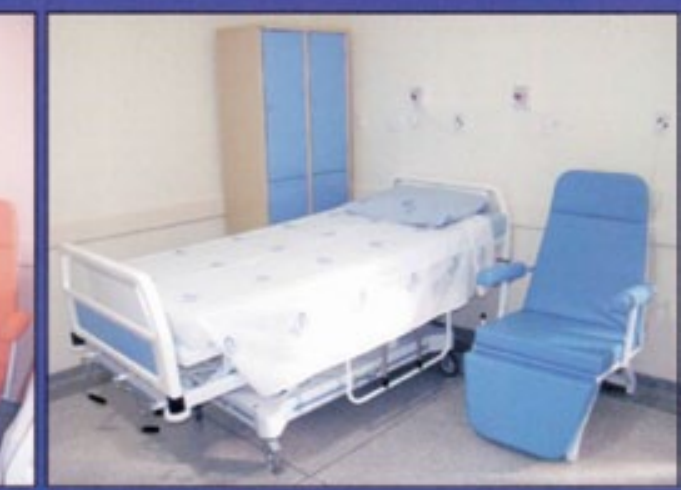

Enfermaria

Masculina do SUS

Graças a Campanha Bate Coraçāo, com o Projeto Adoto um Leito, a Santa Casa "Dona

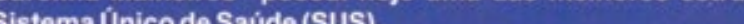

Página 3

\section{Confira como era antes...}

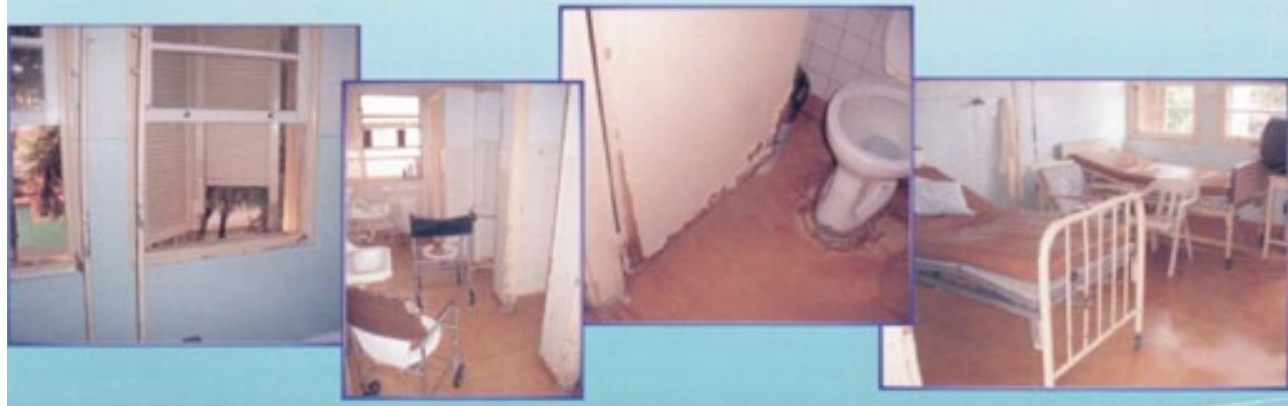

Fig. 16

Folder de divulgação do campanhas para angariar fundos para reformas da Santa Casa Dona Carolina Malheiros. Fonte: acervo da Santa Casa Dona Carolina Malheiros 
Este processo de revitalização está em andamento. Algumas alas já foram reformadas, como a dos leitos destinados aos usuários de convênios e particulares e parte dos leitos destinados aos usuários do Sistema Único de Saúde. Da mesma forma, o centro cirúrgico e as Unidades de Tratamento Intensivo (UTIS) estão completamente reformadas o que impõe um mínimo de qualidade a ser oferecido aos usuários. Também receberam investimentos e foram totalmente modernizadas as áreas de laboratório de análises clínicas, o ambulatório geral, a clínica de fisioterapia, a hemodiálise, o banco de sangue e a oncologia. Setores estes totalmente terceirizados a empresas especializadas nas respectivas áreas de atuação. Desta forma, a credibilidade da instituição, principalmente relacionada à qualidade dos serviços começa a ser recuperada. Tal fato se nota principalmente quando se fazem as pesquisas de satisfação do SUS: a instituição é muito bem avaliada pelos usuários em geral.

Sua estrutura inicial, horizontal e do tipo pavilhonar ainda existe até hoje. Aliás, a estrutura física da Santa Casa pouco cresceu. Na verdade ela foi praticamente reorganizada e reformada em sua própria estrutura original. Houve ampliação, mas se comparada à área total que se aproxima de 13.000 metros quadrados, o percentual de ampliação foi muito pequeno. Tal raciocínio inclusive permanecerá nos próximos passos da recuperação, pois inclusive as novas atividades que estão nos planos dos administradores como hemodinâmica e UTI Neonatal têm planos de ser instaladas em áreas já existentes.

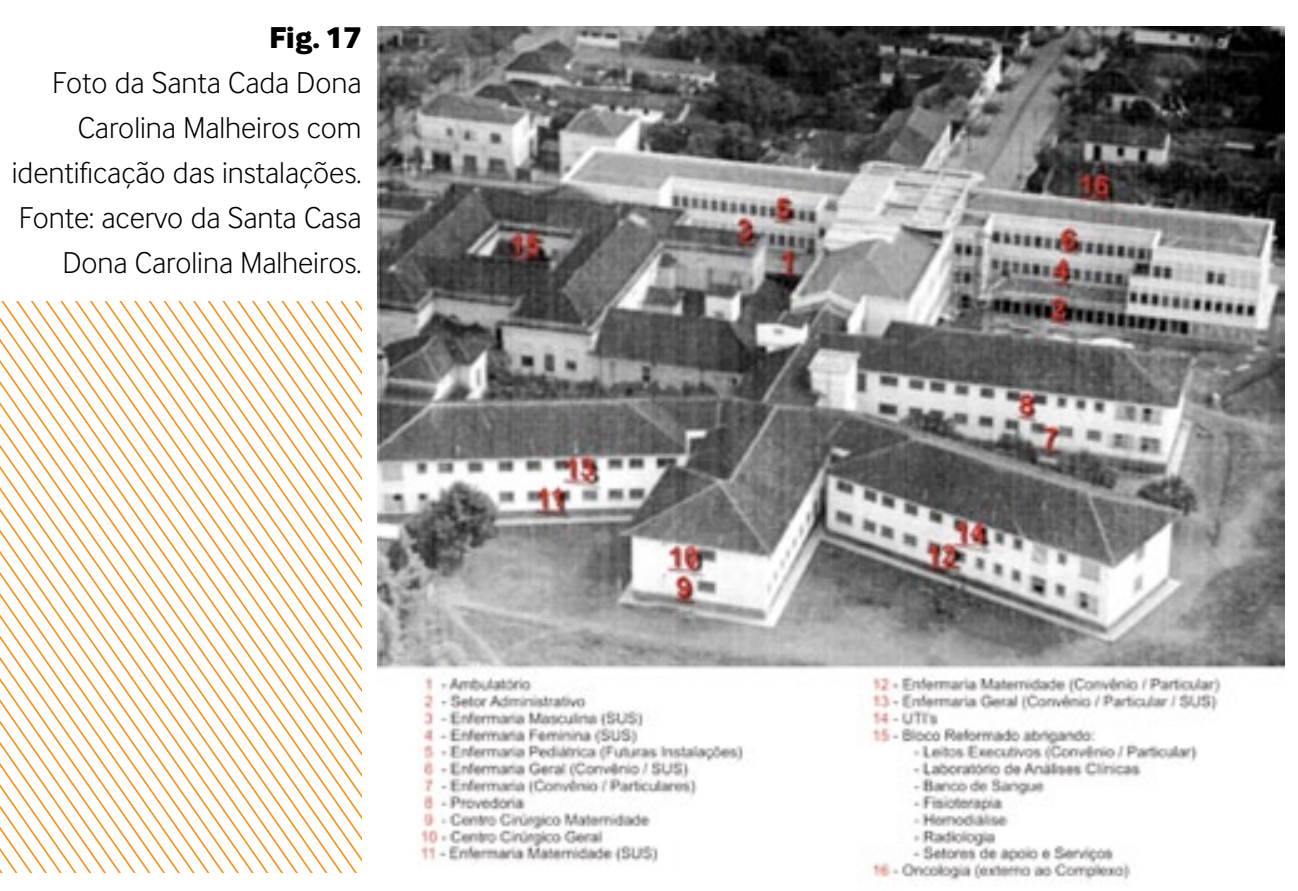

De certa forma, a maior vantagem que o modelo pavilhonar de implantaç̃o oferece está sendo, ou foi totalmente comprometido. O espaço vazio existente entre os pavilhões, inicialmente utilizados como áreas de jardins, ventilação, atualmente estão sendo praticamente todas ocupadas por estacionamentos, coberturas metálicas feitas sem planejamento ou mesmo pequenas obras para instalação de apoios que deveriam ser mais bem planejadas e locadas para inclusive melhor trabalharem. 0 fato é que as enfermarias, áreas de maior permanência dos utentes internados, é que são os ambientes mais prejudicados, pois a visão de suas janelas ao invés de trazerem algum tipo de conforto acaba por trazer prejuízo visual, pois não há atrativo algum para o utente querer ter uma visão do exterior. Ao contrário, incentiva a que as janelas das enfermarias a fiquem fechadas, obrigando a utilização de condicionamento de ar artificial. além de que uma série de outros benefícios se perde de maneira despercebida. Tal valor é colocado muito claramente na citação de SAMPAIO:

De acordo com HOPKINSON \& KAY (1969 apud SAMPAIO, ANA VIRGINIA CARVALHÃES DE FARIA, p. 186), uma janela possibilita descanso visual pois permite uma ligação direta com o mundo exterior, com as diferentes variacõoes que ocorrem no decorrer de um dia 0 homem tem necessidades de variação, mudança, e as janelas favorecem um relaxamento físico e psicológico, pois permitem o deslumbrar do infinito sem a necessidade de forçr o músculo e acomodação como ocorre quando se observa alguma coisa próxima. ${ }^{1}$

Nesta instituição especificamente, busca-se muito a obtenção de conforto nas enfermarias através de decoração, equipamentos eletrônicos, mobiliário atual. Muito é valorizado, por exemplo, o fato de o apartamento executivo, como é chamada a enfermaria destinada aos convênios, ter acesso à internet sem fio, TV com programação a cabo, ar condicionado e cama com ajustes eletrônicos.

O problema não é a oferta destes produtos a quem por eles pode possa pagar de forma particular ou conveniada a algum plano de saúde; o problema é que erroneamente tais artifícios estão sendo utilizados de maneira a compensar a falta da qualidade do ambiente em função da má organização do edifício.

Quando comparado ao que existia há poucos anos, o que há atualmente é muito melhor.

Curiosamente, os leitos mais valorizados por este raciocínio de valorização através destes artifícios, são os leitos com pior localização dentro do complexo. Como se pode ver na implantação colocada no início, tais leitos ficam nos pavilhões intermediários e são eles que dão acesso visual aos antigos vazios hoje mal utilizados. Como o complexo encontra-se instalado em parte alta da cidade, também é curioso constatar que os melhores leitos, aqueles voltados 
para frente do complexo por terem contato com a rua e consequente visão para toda a cidade que é emoldurada pela serra da Mantiqueira, são os destinados aos usuários do SUS. Tal fato é muito interessante para ser colocado, pois tais instalações são as mais simples, não oferecem o mesmo aparato tecnológico e acabam por se tornar os ambientes mais confortáveis do complexo. Não se pode afirmar, mas parece não ser intencional.

De forma geral, percebe-se que arquitetonicamente a instituição não está bem orientada. Há sim preocupação com a questão da humanização dos ambientes, isso fica claro na preocupação que existe com a utilização de cores, de mobiliário confortável etc., mas tal preocupação demonstrase insuficiente ou mais, leiga, pois até mesmo as maiores vantagens existentes desde o início de funcionamento do complexo, que é a sua implantaç̃a acaba por se perder ao ser mal utilizada.

Também se nota que, não é só na questão da humanização que não se tem qualidade. Há utilização errada de materiais, como pisos mal especificados e instalados. Ou seja, mesmo a questão da segurança ou até mesmo prevenção à infecção hospitalar fica comprometida.

De forma objetiva, pode-se concluir que o complexo hospitalar busca melhorar suas características e qualidades perdidas com o passar do tempo. Mas, é preocupante assistir tal processo de recuperação acontecer de maneira desorientada. O resultado final já pode ser percebido e ficará cada vez mais evidente: a sensação ao se caminhar pelo complexo, não é uma sensação de bem-estar. Em nada neste caso o ambiente contribui para isso. Pior, quando se analisa isso com o olhar do utente, os momentos de internação vividos nestes locais certamente não oferecerão boas lembranças.

A seguir, ilustração que mostra como ficaram os leitos destinados aos atendimentos particulares e conveniados. Nestas imagens pode se notar o investimento em equipamento de ar condicionado, cama com controles e ajustes eletrônicos, existência de TV, no caso com programação a cabo. Vale observar também que as janelas encontram-se fechadas.

\section{Fig. 18}

Foto ilustrativa da enfermaria dest aos usuários de convênios e particulares da Santa Casa Dona Carolina Malheiros. Fonte: acervo da Santa Casa Dona Carolina Malheiros

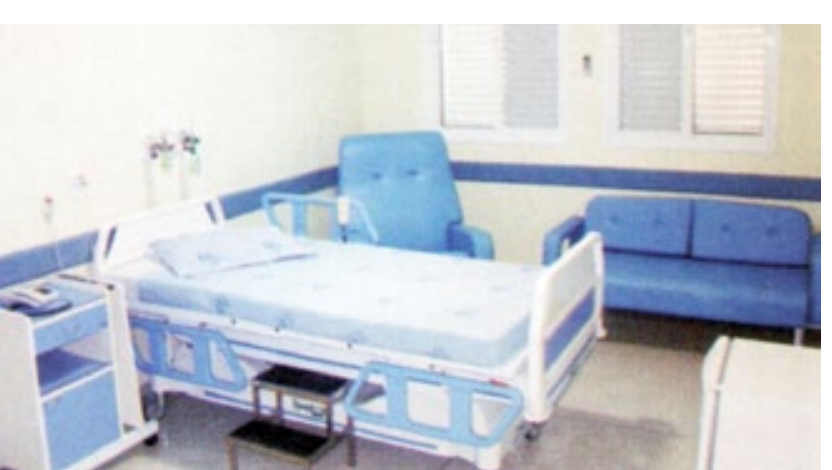

Ainda na ala, fotos das áreas de circulação e espera, onde nota-se a preocupação com a decoração, porém aspectos básicos são desconsiderados, como ventilação e iluminação naturais. Inclusive por questões de economia, as vezes as luzes destes ambientes ficam apagadas, o que confere a eles uma sensação muito desagradável e de insegurança.
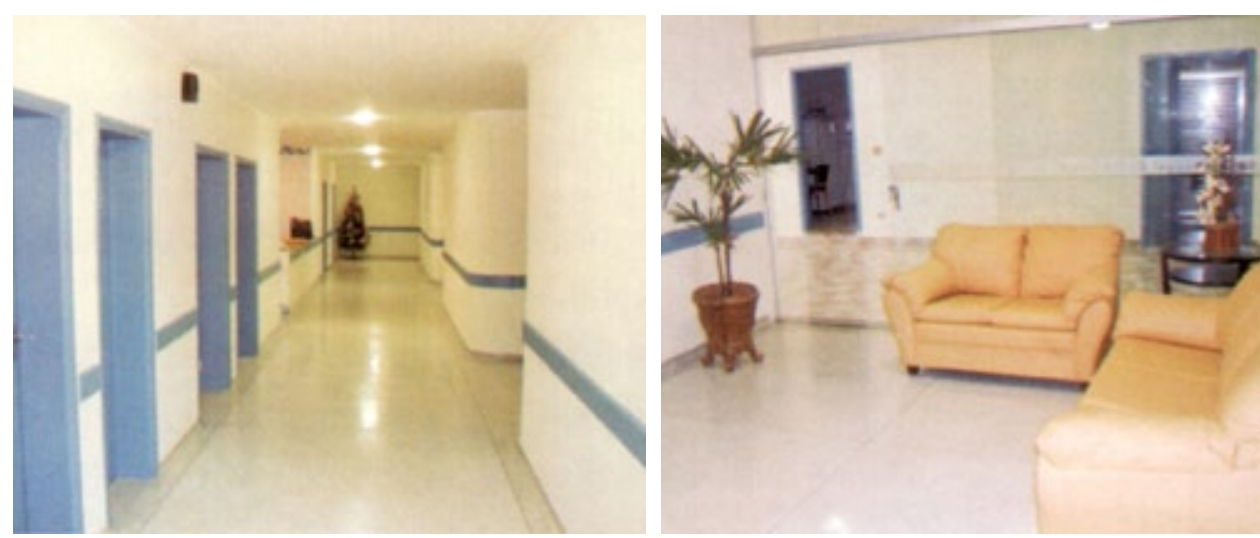

Fig. 19

Fotos das áreas

de uso comum da ala destinada aos usuários

de convênios e particulares da Santa Casa Dona Carolina Malheiros. Fonte: acervo da Santa Casa Dona

A seguir, fotos que ilustram como ficaram as enfermarias destinadas ao atendimento SUS, da ala masculina e feminina respectivamente. Vale salientar que neste caso, o fato de as janelas estarem abertas já confere maior qualidade ao ambiente desprovido de itens de conforto adicional.
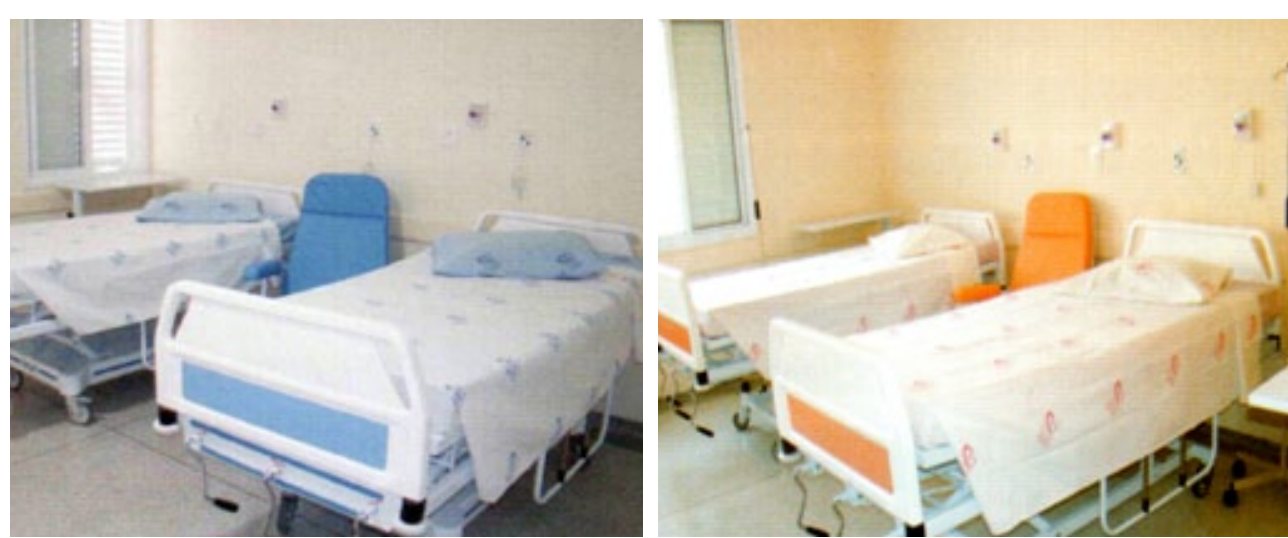

Fotos ilustrativas

das enfermarias

masculinas

e femininas

destinadas ao SUS

na Santa Casa Dona

Crolina Malheiros.

Fonte: acervo da

Santa Casa Dona

Carolina Malheiros

Abaixo, as ilustraç̃oes demonstram algumas das instalacõos terceirizadas a empresas especializadas. Na primeira sequência de fotos, tem-se o ambulatório totalmente reformado com objetivo de atender tanto usuários particulares quanto conveniados e do Sistema Único de Saúde (SUS) e que se encontra instalado em um dos andares do pavilhão frontal do complexo. Na segunda sequência de fotos, tem-se o setor de oncologia, totalmente construído para esta finalidade e em estrutura física separada do complexo. Nesta unidade, já se percebe um maior cuidado com a iluminação e ventilação naturais, a presença de paisagismo. 

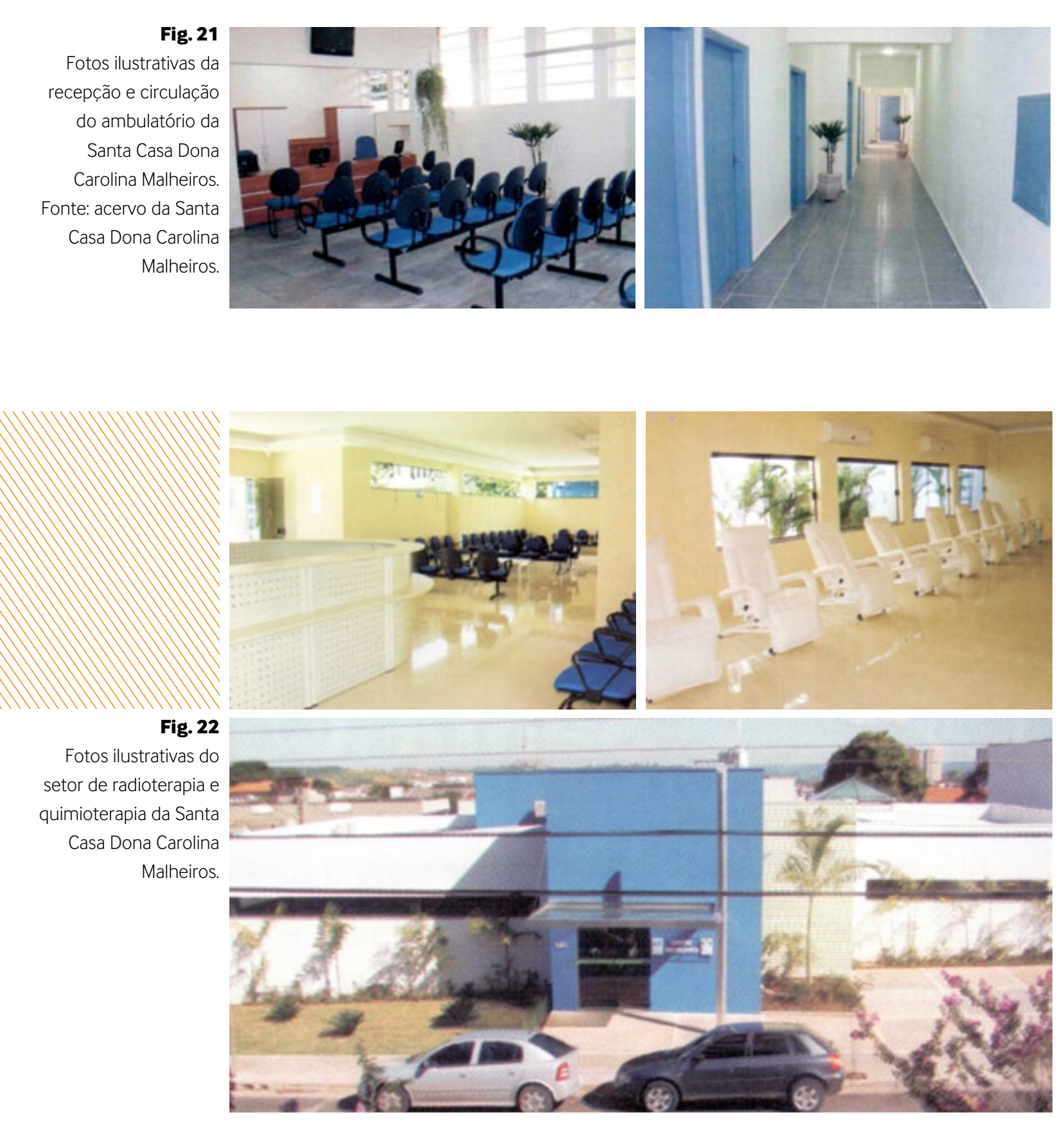


\section{Capítulo 5 \\ Abordagens Teóricas x Análises Práticas : A Humanização Entre A Teoria E A Prática}


Através deste capítulo, com as abordagens teóricas claramente colocadas e com a análise de exemplos práticos realizada, busca-se estabelecer uma comparação entre a teoria e a prática, para se concluir se os aspectos abordados na teoria são reais. Se sim, identificar como foram empregados e como funcionam na prática. Se parcialmente, quais foram e quais não foram praticados, além de buscar o motivo pelo qual atenderam parcialmente suas finalidades. Se não, buscar-se entender o porquê disso. Além disso, verificar se a prática mostra algum aspecto que a teoria não mostra.

\subsection{Valorização do "olhar diferenciado" do utente}

Para iniciar-se esta abordagem de comparação, vale antes resgatar a questão da valorização do utente: se o utente tem seu valor reconhecido pelas instituições e se elas têm o "olhar diferenciado" quanto ao ponto de vista do utente na questão dos ambientes.

Tal análise, não pode ser colocada de maneira a ser fisicamente comprovada. Tal percepção não tem critérios de avaliação e na verdade só pode der adquirida emocionalmente, pressupondose, assim, que só se tirar conclusões diretamente no local considerado. Desta forma, coloca-se nesta abordagem uma opinião subjetiva que pode em alguns casos ter aspectos físicos que a evidenciem. Quando isso ocorrer, serão apresentados.

No Hospital Escola Municipal de São Carlos, por ser um hospital projetado por Lelé (João Filgueiras Lima) constata-se que este "olhar diferenciado" existe. Embora a construção do hospital não esteja totalmente finalizada, o que está funcionando atualmente mostra essa existência, do mesmo modo que os demais projetos elaborados por ele, onde o contexto ambiental todo se volta para trazer benefícios aos utentes e assim influenciar de maneira benéfica em sua recuperação. Como já se colocou, embora ainda não estejam ainda prontas as áreas destinadas à internação, a presença de elementos marcantes da arquitetura de Lelé já se nota, concluindo-se, então, que, como acontece na parte que já está em funcionamento as demais terão a mesma qualidade ambiental. 
O Hospital do Câncer de Barretos mostra-se o que mais tem este "olhar diferenciado". Embora pareça acontecer de maneira espontânea, sem planejamento, ou seja, não houve projeto para se atingir esta meta, mas tanto os ambientes como o tratamento oferecido aos utentes, aos familiares e aos visitantes evidenciam esta preocupação. Como foi abordado, o ambiente exala confiança e felicidade, itens fundamentais para a recuperação do utente.

Na Santa Casa de Porto Alegre, este "olhar" existe, porém, não em relação à arquitetura toda mas no tratamento dispensado aos usuários. Na arquitetura, ele pode ser notado nas instalações mais contemporâneas, embora isso tenha ocorrido de maneira inconsciente, ou seja, sem ter sido programada. Explica-se isso muito mais pelo fato de estas atuais obras seguirem tendências arquitetônicas modernas, passando a sensação de segurança aos usuários o que consequentemente, resulta numa relação de confiança entre instituição e usuário.

Na Santa Casa Dona Carolina Malheiros, em São João da Boa Vista, tal percepção existe, porém este "olhar" tem uma interpretação errada: busca-se valorizar o utente através da arquitetura, porém erros conceituais não permitem, e, quando permitem parecem ser de maneira não proposital.

Como exemplo disso, coloca-se que atualmente ala de maior valorização por parte da administração local, é a ala denominada dos leitos executivos. Tal ala é destinada ao atendimento de usuários de convênios e particulares. O que chama a atenção é o fato de tal ala, a mais valorizada do conjunto, ser a ala de pior localização. E, conforme foi evidenciado, perde uma de suas principais qualidades ao se ocupar os espaços vazios entre os pavilhões com construções mal planejadas. Ou seja, tais enfermarias têm sérios problemas de conforto em diversos aspectos, confortos estes compensados com elementos de hotelaria, decoração, com certo luxo. Contudo, a ala de menor valorização, a ala do SUS, que ainda nem passou por reformas de revitalização, é a ala frontal, que tem em boa vista e consequentemente boa relacão com o exterior, sua maior vantagem. № entanto, são estas as enfermarias menos valorizadas pela administração

\subsection{Sob a ótica da legislação}

Do ponto de vista da legislação, todos os exemplos analisados são eficientes, ou seja, todos atendem às normas em vigor. Aliás, não poderia ser diferente, pois se não atendessem, não teriam aprovação dos órgãos públicos para funcionar. É exatamente esta situação que permite entender que não é a existência das normas e o fato de elas serem seguidas que tornam os Estabelecimentos Assistenciais de Saúde bons ou ruins.
Alguns exemplos de situações que as normas são totalmente seguidas, porém com resultados bastante diferentes:

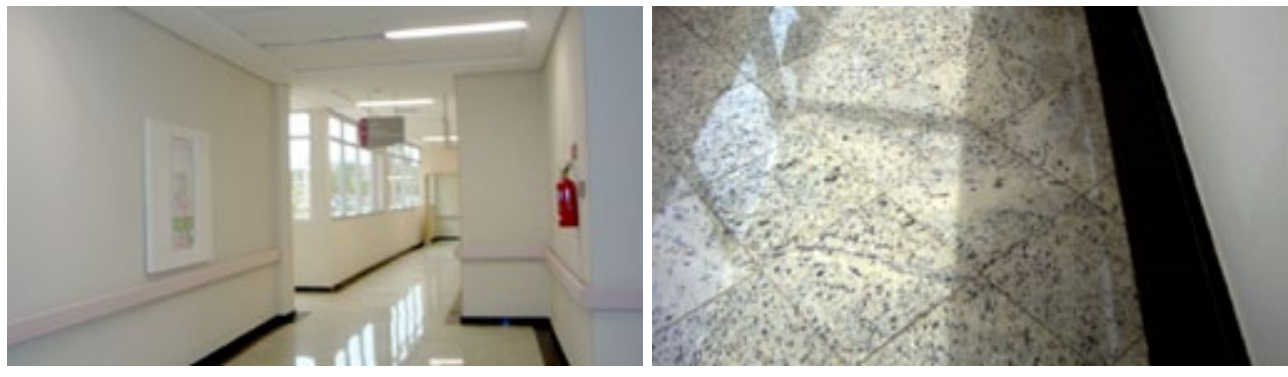

Fig. 23

Fotos do Hospita do Câncer de Barretos mostrando piso utilizado. Fonte: acervo pessoal.

Acima, fotos de ala do hospital de Barretos no qual, como piso da área de circulação, é utilizado granito natural polido como revestimento de acabamento de piso.

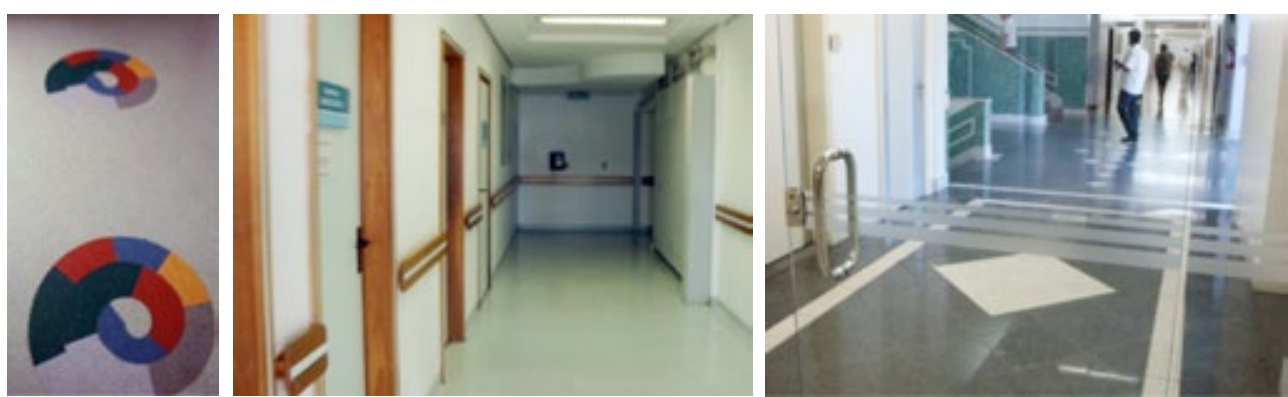

Fig. 24

Fotos da Santa Casa de Porto Alegre mostrando os pisos utilizados Fonte: acervo

pessoal.

Acima, fotos de diferentes áreas da Santa Casa de Porto Alegre exemplificando a diversidade de revestimentos de piso utilizados. Nas instalacõos mais antigas, tem-se granito como acabamento, nas mais novas revestimento emborrachado.

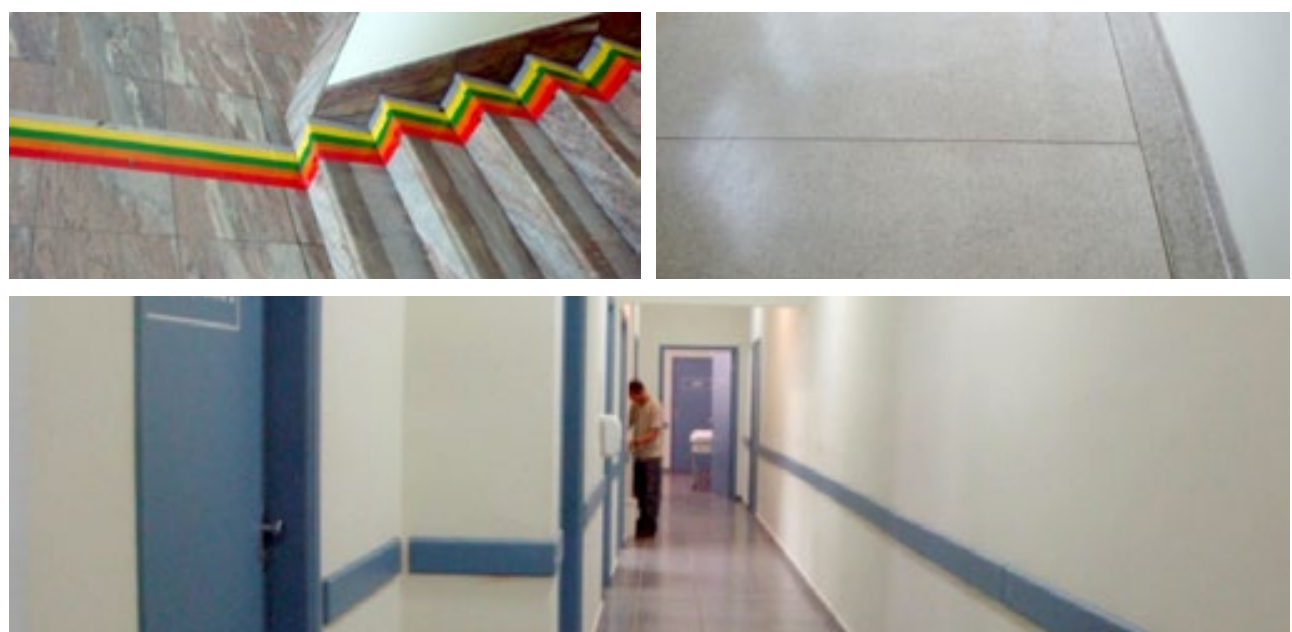

Fig. 25

Fotos da Santa

Caso Dona

Carolina Malheiros

mostrando os pisos

utilizados.

Fonte: acervo

pessoal. 
As fotos da página anterior são de alguns ambientes da Santa Casa D. Carolina Malheiros em São João da Boa Vista, onde em um ambiente tem-se o piso com revestimento cerâmico, em outro com mármore e em outro, ainda, o revestimento conhecido como granilite.

Tais exemplos foram colocados por ilustrarem de maneira clara que as normas admitem inúmeras possibilidades de revestimentos de piso. Salienta-se que todos estes exemplos são aprovados pela RDC no. 50 e todos os ambientes têm autorização para funcionar. O que não se pode deixar de colocar é que embora tudo esteja legal, alguns revestimentos são melhores que os outros. 0 revestimento emborrachado, por não ter emendas e por permitir o acabamento redondo nas junções entre piso e parede, ser impermeável e totalmente liso, sem poros, representa a melhor opção dentre os pisos exibidos.

Os revestimentos cerâmicos são impermeáveis e estanques, sem poros, por esse motivo representam também boa opção de acabamento, porém apresentam uma quantidade de juntas bastante grande e não permitem um acabamento satisfatório na junção entre piso e parede, criando cantos

Os pisos executados em pedras naturais, como mármores e granitos, por serem naturais, embora impermeabilizados após sua aplicação, apresentam a existência tanto de poros quanto de juntas entre as peças. Em alguns casos, apresentam também baixa resistência mecânica e são altamente absorventes e, com o passar do tempo, ficarão comprometidos.

O revestimento de piso conhecido como granilite, na verdade é uma massa de cimento e pó de mármore/granito com adicão de resina, apresentando a pior opcão dentre as ilustradas. Tal piso, embora não apresente grande quantidade de juntas e também permita o acabamento arredondado na junção entre parede e piso, revela-se muito poroso e absorvente. Situação comum nos ambientes que o utilizam é ver a máquina de limpeza deixar um rastro clareado por onde passa limpando, demonstrando desta forma a absorção de sujeita pelo material.

Assim, pode-se concluir que as normas vigentes dão margem à utilização de inúmeros materiais e desta forma permite o funcionamento de estabelecimentos que por qualquer motivo utilizam o material menos indicado. Temos nas ilustrações, demonstração de uma grande variedade de utilização de material, inclusive em um mesmo hospital. São exemplos simples que demonstram que, embora as normas possam ser perfeitamente obedecidas, o que impõe qualidade ao ambiente é o bom senso do projetista. Como já se disse, ainda que se obedeçam as normas, pode-se fazer tanto um bom quanto um projeto ruim.

\subsection{Valorização dos profissionais da saúde.}

Por valorização do profissional da saúde, entende-se principalmente a valorização daqueles que são os responsáveis pelo tratamento do utente dentro dos estabelecimentos assistenciais de Saúde, independentemente de sua função - de apoio, administrativa ou técnica.

Enquanto os utentes passam nestes locais horas, dias, semanas ou meses em tratamento os profissionais passam todo o tempo durante muitos anos. Eles vivem dentro destes estabelecimentos. Desta forma, como já foi abordado, visa-se oferecer a eles as melhores condições de trabalho. A humanização dos ambientes também deve beneficiar tais profissionais.

Nos estabelecimentos analisados, as instituicões têm maneiras diferentes de valorizar seus profissionais. Como exemplo, tem-se a equipe médica que, tendo contato direto com os utentes, é a grande responsável pelo seu tratamento.

No Hospital Escola Municipal de São Carlos, a qualidade do ambiente proporcionada, abrange todos os ambientes do estabelecimento e consequentemente oferece boas condições de conforto a todos que nele estão. Não há distinção entre equipe médica e utente. Não há ambientes privilegiados, nem para um nem para outro, médico ou utente. O que há, são ambientes com necessidade de controle de temperatura que necessitam de ar-condicionado, por exemplo, não com a finalidade de oferecer conforto, mas com a finalidade técnica de controle. Ou seja, neste caso, quando a arquitetura privilegia a qualidade do ambiente, todos saem ganhando, inclusive os trabalhadores da saúde que ali passam todo o tempo em que estão trabalhando.

No Hospital do Câncer de Barretos, a instituição tem duas maneiras principais de valorizar a equipe médica. A primeira é a valorização financeira. Conforme dito, os médicos da equipe têm remuneração equivalente a dos médicos europeus. Mais, tais médicos têm obrigatoriamente que apresentar uma produção acadêmica por ano o que garante a eles e à instituição uma constante atualização profissional. Para que a equipe possa atingir tal meta, a instituição oferece além das instalações particulares a cada um (sua sala), uma sala de estudos bastante completa e confortável com biblioteca e terminais de estudo e pesquisa. As fotos a seguir exemplificam tal situação.

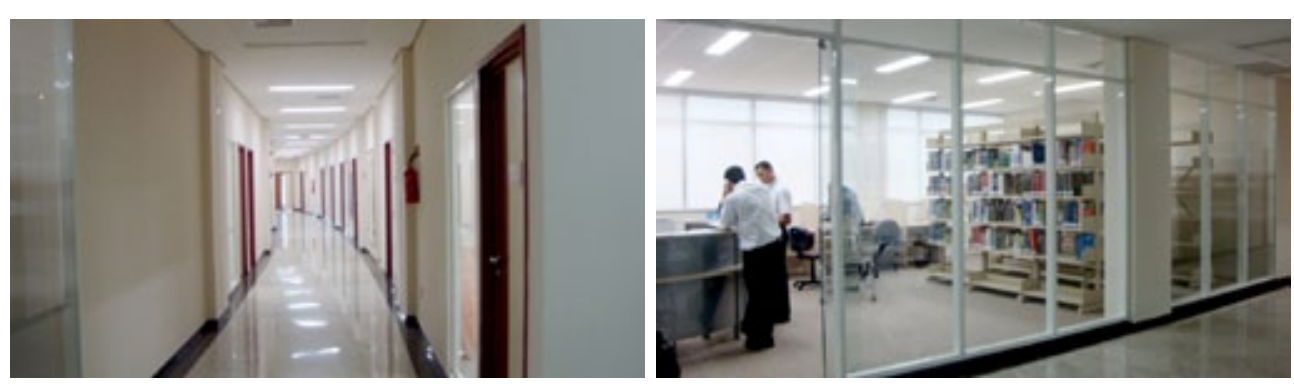


Além disso, os ambientes de estar voltados aos profissionais, neste caso não somente os médicos. pretendem ser confortáveis e agradáveis valorizando os momentos de relaxamento e descanso dos funcionários. É o demonstram as fotos a seguir.

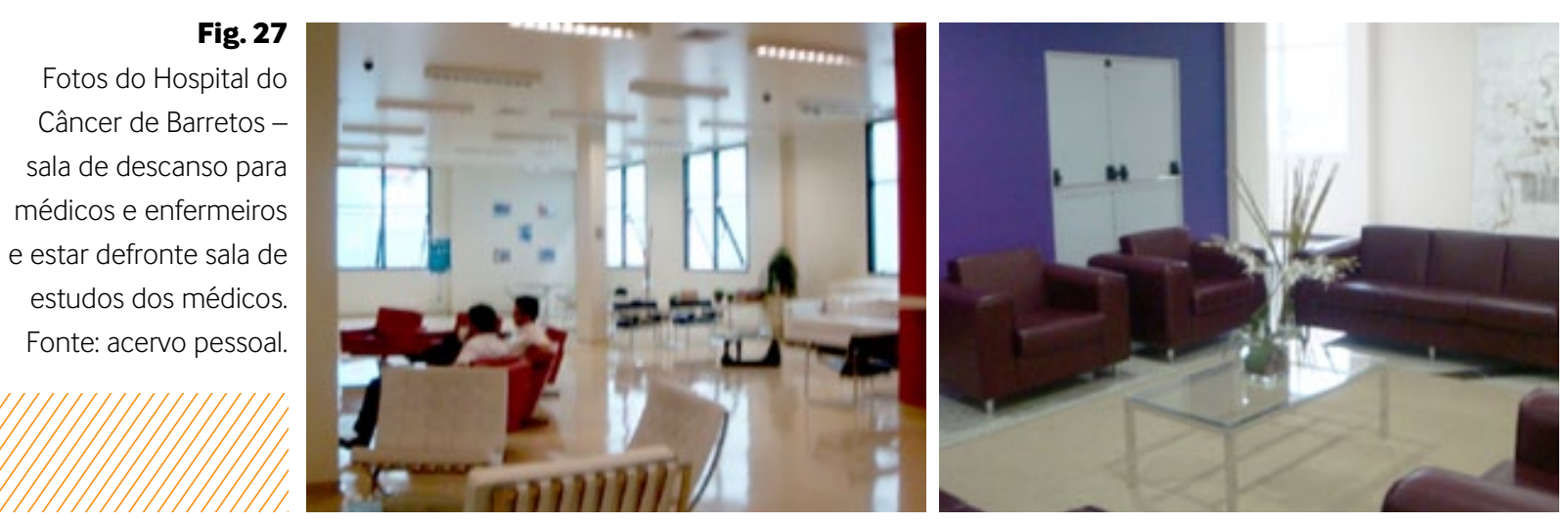

No caso da Santa Casa de Porto Alegre, a valorização do profissional tem sentido diferente A administração entende que os funcionários que lá trabalham, por lá trabalharem têm certo status profissional, o que garante o interesse em continuarem lá trabalhando. No caso da equipe médica, os profissionais podem trabalhar também em outras instituições ou mesmo em clínicas particulares, o que thes confere rendimento extra para compensar a remuneração não tão alta oferecida pela instituição. Desta maneira tais profissionais viabilizam o aspecto financeiro, mantendo o status de pertencer à equipe a Santa Casa de Porto Alegre; a situação colocada não pode ser generalizada a toda a equipe.

Outro fator que aumenta o interesse dos profissionais pela instituição é a aprendizagem, já que a instituição reconhecidamente é uma instituição também de ensino e por seu porte e qualidade oferecida acaba por propiciar conhecimentos aos funcionários.

Com relação à arquitetura, o que ela tem a oferecer de benefício aos funcionários é o mesmo oferecido aos usuários em geral, ou seja, espaços públicos e de convívio agradáveis e de qualidade. É comum assistir tanto funcionários em horário de descanso quanto utentes passeando pelas instalações, praças, lanchonetes da instituição. Estes espaços físicos oferecem bastante qualidade ambiental aos usuários, todos eles. Não há instalações destinadas exclusivamente ao uso dos médicos ou funcionários. É normal ver usuários almoçando ao lado de médicos ou enfermeiros nos restaurantes da instituição. Tais ambientes agradam os usuários, pois, embora ao redor da instituição existam inúmeras opções de restaurantes, bares, etc. (vale salientar que a Santa Casa está instalada na região central da Cidade) estes geralmente preferem permanecer no hospital e lá fazer seu relaxamento ou refeição.

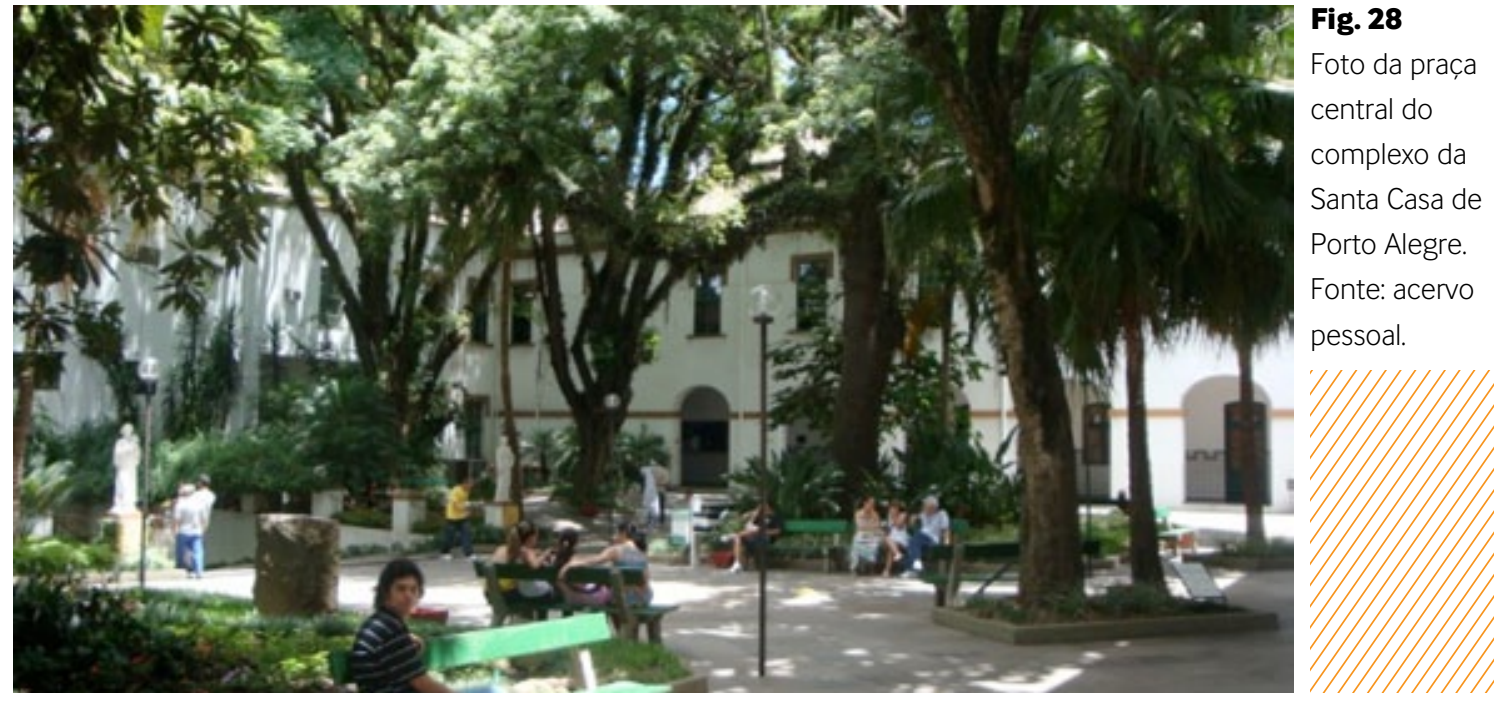

Na Santa Casa D. Carolina Malheiros, de São João da Boa Vista, como a instituição está passando por momentos de revitalização, pouco se investiu até o momento neste quesito. Porém, há por parte da administração uma demonstração de preocupação com o assunto. Há em uma sala adaptada, uma área destinada ao descanso dos funcionários. Nesta sala hấ sofás, televisão, computadores com acesso à internet e uma pequena copa. A cidade, por ser pequena, cultiva o hábito de as pessoas fazerem suas refeiç̃ões em casa, pois o tempo gasto com locomoção costuma ser pequeno, mas para aqueles que moram em locais mais distantes, há um local para esquentar seu almoço trazido de casa, fazer um lanche ou simplesmente relaxar nos momentos de descanso.

A seguir, as fotos deste local descrito no qual se nota a total adaptação do espaço.
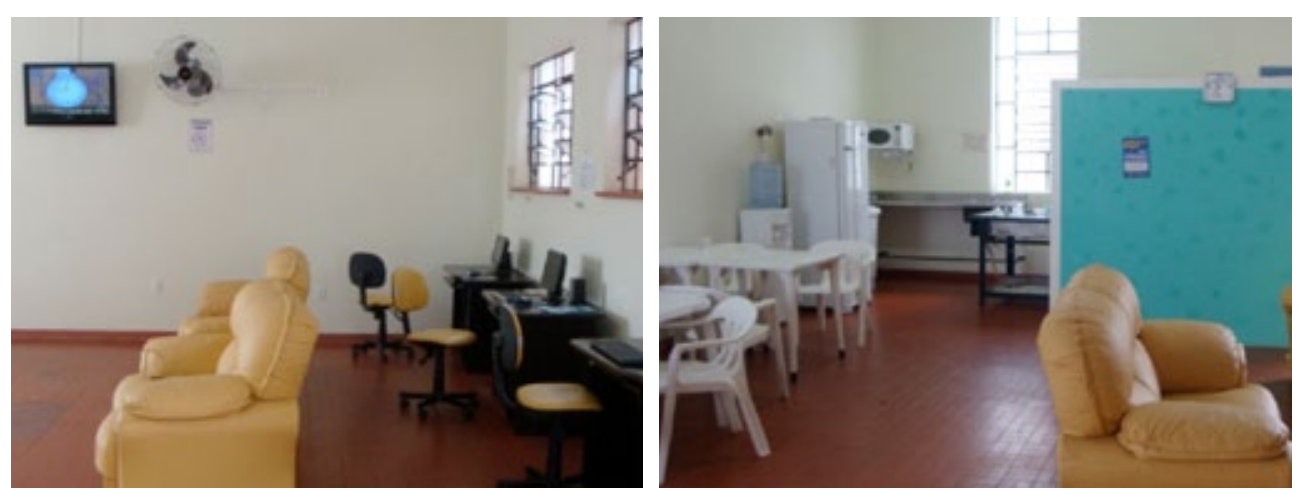
Fig. 29 Fotos da área de descanso dos funcionários da Santa Casa Dona Carolina Malheiros. Fonte: acervo pessoal.

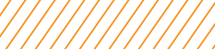


Para os médicos, a situação é diferente. Não há espaço como este. Da mesma forma, como o tempo de locomoção costuma ser pequeno, tais profissionais preferem passar seus momentos de descanso em casa ou mesmo em seu consultório, geralmente instalado nas proximidades da Santa Casa. O que existe, são os ambientes conhecidos como "ambientes de conforto médico", porém estes são utilizados pelos médicos plantonistas e não como espaços de convívio.

\subsection{Valorização dos Espaços pela Arquitetura}

Para se ter um entendimento mais didático e até mesmo abrangente na abordagem teórica, buscou-se elencar, na questão da arquitetura para os Estabelecimentos Assistenciais de Saúde, os chamados requisitos básicos, que são os requisitos capazes de influenciar o ambiente proporcionando a ele uma qualidade distinta de qualquer subterfúgio de luxo, decoração, hotelaria, etc., para ser considerada boa. Desta forma, entende-se que estes elementos de luxo são considerados acessórios, que podem ou não ser utilizados, mas não são eles os responsáveis por identificar ambientes de qualidade. Entende-se que, mesmo sem luxo algum, os ambientes podem ser considerados humanizados, atendendo a qualquer tipo de usuário, em especial, os usuários do Sistema Único de Saúde - SUS.

Os requisitos que respondem a esta postura e que foram listados são: adequação ao local: o projeto deve resultar de um estudo funcional e técnico do problema; racionalização das circulações e agrupamento de usos e atividades afins: auxilio na prevencão à infecção hospitalar: flexibilidade dos ambientes; preocupações com conforto ambiental - conforto térmico e conforto visual; presença de verde; relação interior x exterior; e humanização dos espaços.

Para se saber se as abordagens teóricas têm relação com os exemplos práticos analisados, uma análise de cruzamento de informações entre as duas, será feita para cada requisito em cada estabelecimento.

\subsubsection{Adequação ao local}

Este requisito, de maneira bastante resumida, tem as seguintes características já abordadas: avaliação da topografia; insolação; acessibilidade - de pacientes, de médicos, de funcionários, de emergência, de transporte público, etc;; análise do entorno; e capacidade para ampliações futuras.

A importância do arquiteto projetista, quando da escolha do local, torna-se, sob esta ótica, imprescindível, pois é ele que tecnicamente terá condições de orientar o empreendedor sobre de todas estas situações que devem ser consideradas.

Todos os estabelecimentos analisados já estão instalados e em funcionamento e a pesquisa, por este motivo não tem condições de analisar o requisito de maneira integral para entender quais os porquês das decisões tomadas. Tem, entretanto, condição de avaliar se, após o tempo de uso de cada um, a adequação ao local se deu de maneira correta e coerente.

Com relação a este requisito todos os estabelecimentos analisados demonstram-se coerentes em sua adequação ao local, porém cada caso será apresentado a seguir.

No Hospital Escola Municipal de São Carlos, a escolha do terreno parece ter sido acertada, pois o hospital tem perfeitas condições de acesso. Não está no centro da cidade, mas dentro dela. Está integrado à malha urbana da cidade, não está isolado e inclusive permite acesso a partir de outras cidades, pois está em uma das entradas da cidade, próximo à importantes rodovias da região. Ou seja, tem acesso fácil para a população local, tem acesso de emergência fácil, mesmo a partir das rodovias e está integrado ao funcionamento da cidade, contando com transporte público e infra-estrutura básica necessária. Mais ainda: ao mesmo tempo em que está integrado à cidade, não tem comprometimento com alguns problemas que a cidade apresenta geralmente, como poluição sonora, excesso de trânsito e circulação, pois o terreno escolhido para sua implantação de certa forma tem um isolamento do dia-a-dia do funcionamento da cidade, pois seu acesso é exclusivo e seus vizinhos são as rodovias, em grande parte.

O terreno oferece boas condições de adequação do edifício ao clima local e ainda tem área livre para paisagismo, estacionamento e futuras ampliações, o que tem influência fundamental na questão do conforto ambiental.

Com relação à insolação, uma análise mais apurada não foi feita, mas Lelé (João Filgueiras Lima), projetista desta unidade tem postura de referência nesta questão, tanto que na visita, o conforto ambiental dentro do complexo comprovou sua eficiência.

O Hospital do Câncer de Barretos está instalado em um bairro relativamente afastado do centro da cidade, porém próximo a importantes rodovias da região. Como seus usuários, na grande maioria, são de outras cidades e Estados, tal situação revela-se a ideal, pois tem fácil acesso tanto para usuários locais (transporte público, emergência, etc.) quanto para os usuários de outras localidades. 


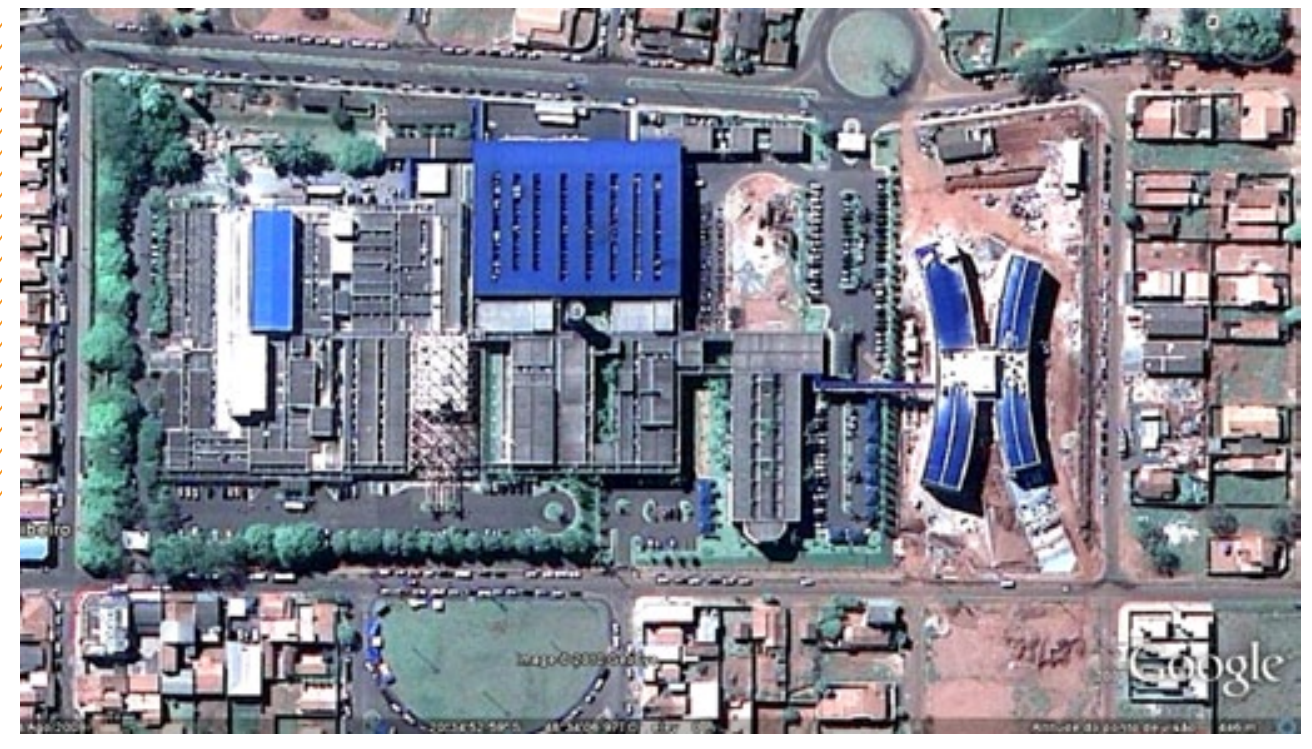

A topografia do terreno mostra-se adequada à sua finalidade. Tanto assim, que a condicão de instalar-se o hospital da forma mais horizontal possível pôde ser mantida e, praticamente, todo ele é térreo. Há locais com dois pavimentos, mas com facilidades de acessos e que não se revelam obstáculos ao funcionamento pretendido. O terreno é amplo o suficiente para garantir a implantação no modelo pavilhonar, favorecendo assim as condições de conforto ambiental para seus usuários.

Da mesma forma, o terreno oferece boas condiç̃̃es de ampliação. Inclusive atualmente já estão acontecendo 10 obras de ampliação. Como a ocupação do local ainda é pequena em seu entorno, o hospital tem, além de sua área original, áreas adjacentes, em quadras imediatamente próximas, visando ampliações futuras que não comprometam a implantação atual e suas condições de eficiência.

Neste caso, pode-se concluir que a adequação ao local é eficiente e vem somar-se aos demais requisitos para assim garantir ótimas condições aos usuários e permitir que a arquitetura trouxesse humanização aos ambientes.

As Santas Casas, de Porto Alegre e de São João da Boa Vista, tem situação de adequação ao local com características parecidas. As duas têm muitos anos de existência - Porto Alegre aproximadamente 200 anos e São João da Boa Vista aproximadamente 100 anos - ou seja, é nelas que se pode analisar, ao máximo, se sua adequação ao local foi eficiente. Em geral, e no caso destas duas não foi diferente, as Santas Casas se instalam em locais relativamente afastados e as cidades vão se formando em seu entorno. Por isso, inclusive, suas histórias se confundem com as histórias das cidades. Ou seja, praticamente todas as dificuldades encontradas atualmente quando da instalação dos hospitais novos, como estudo do entorno, condição de insolação, acessibilidade ou dificuldades de ampliação foram encontradas na época de suas instalações.

O que se pode analisar de maneira eficiente, é a condição de implantação atual, entendendo quais as condicõos para este momento da história de suas existências.

Na Santa Casa de Porto Alegre, a implantação com características pavilhonares dos primeiros hospitais do complexo, já estão sendo abandonadas e a tipologia monobloco vertical está surgindo Os dois últimos hospitais construídos já têm esta característica e, qualquer outro que venha a ser construído (por exemplo, a ampliação do Hospital Santa Clara - hospital geral, maior e mais antigo do complexo) terá obrigatoriamente que adotar tal característica. Há espaços disponíveis, mas se forem ocupados certamente comprometerão a implantaç̃ão dos edifícios existentes.

Na Santa Casa de São João da Boa Vista, o edifício original, do tipo pavilhonar ainda se mantém a principal estrutura do hospital. Fato estranho que tem acontecido nos últimos anos é que, apesar de ainda haver espaços disponíveis para ampliações, construções de apoio estão ocupando os originais espaços vazios destinados a jardins e circulações, o que em muito compromete a qualidade dos ambientes.

As fotos abaixo, da implantação original e foto aérea da atual, ilustram o que foi colocado.
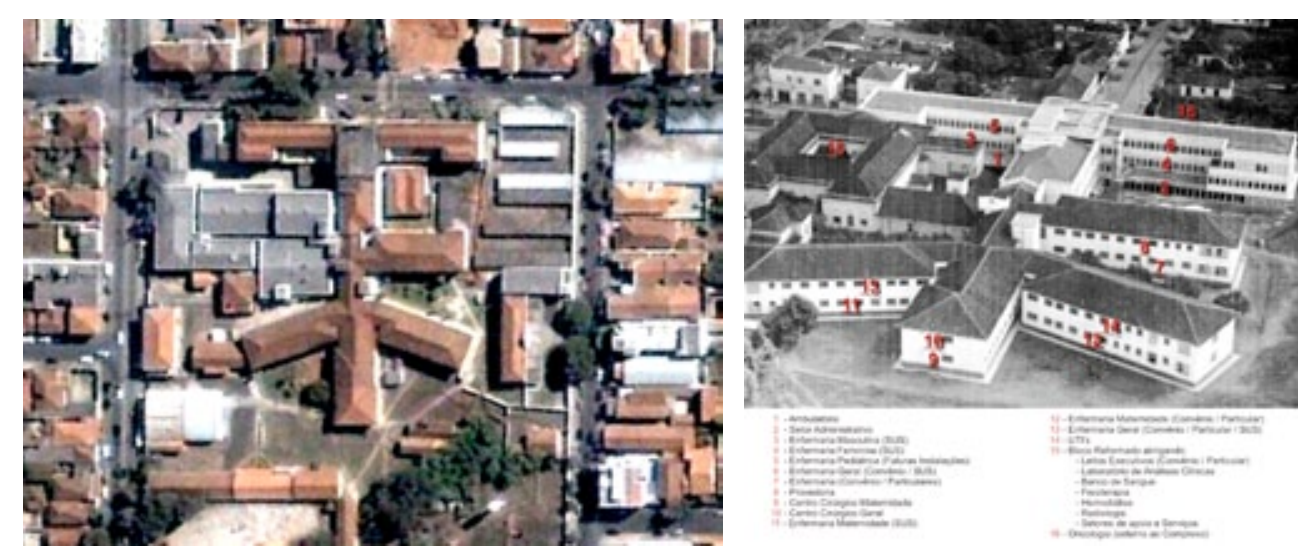

Fig. 31

Fotos de satélite e aérea da Santa Casa Dona Carolina Malheiros. Fonte: acervo da Santa Casa Dona Carolina Malheiros 
As fotos a seguir ilustram como ficaram os espaços vazios atualmente ocupados com instalações de apoio.

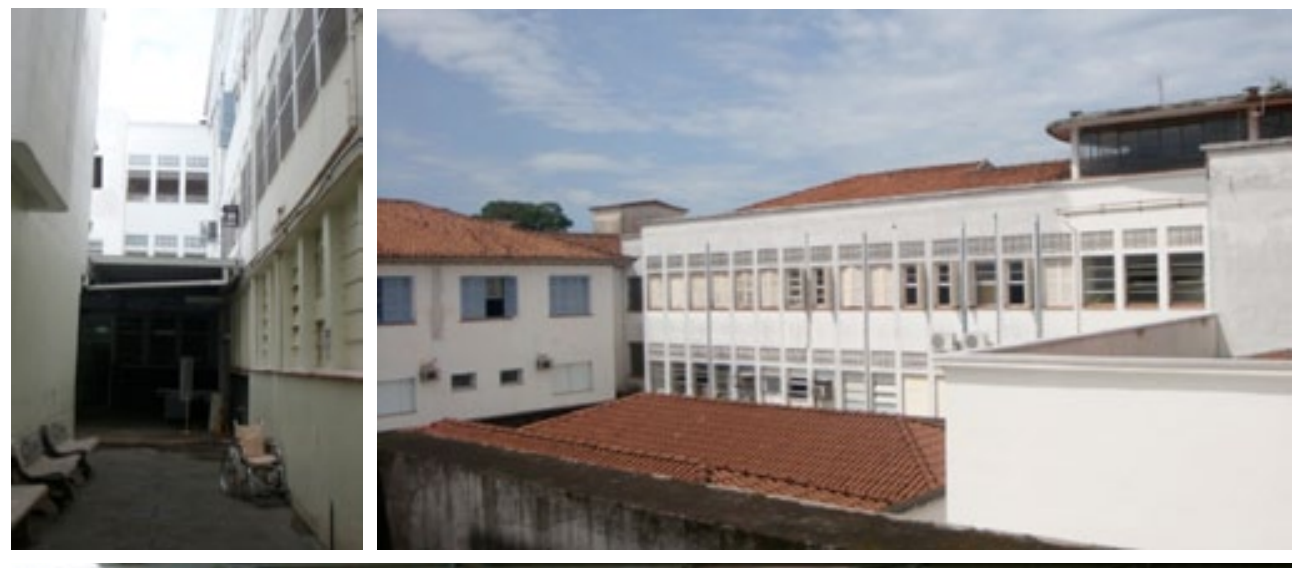

Fig. 32 Fotos ilustrativas antigos espaços vazios entre os pavilinões da Santa Casa Dona Carolina Malheiros. Fonte: acervo pessoal.

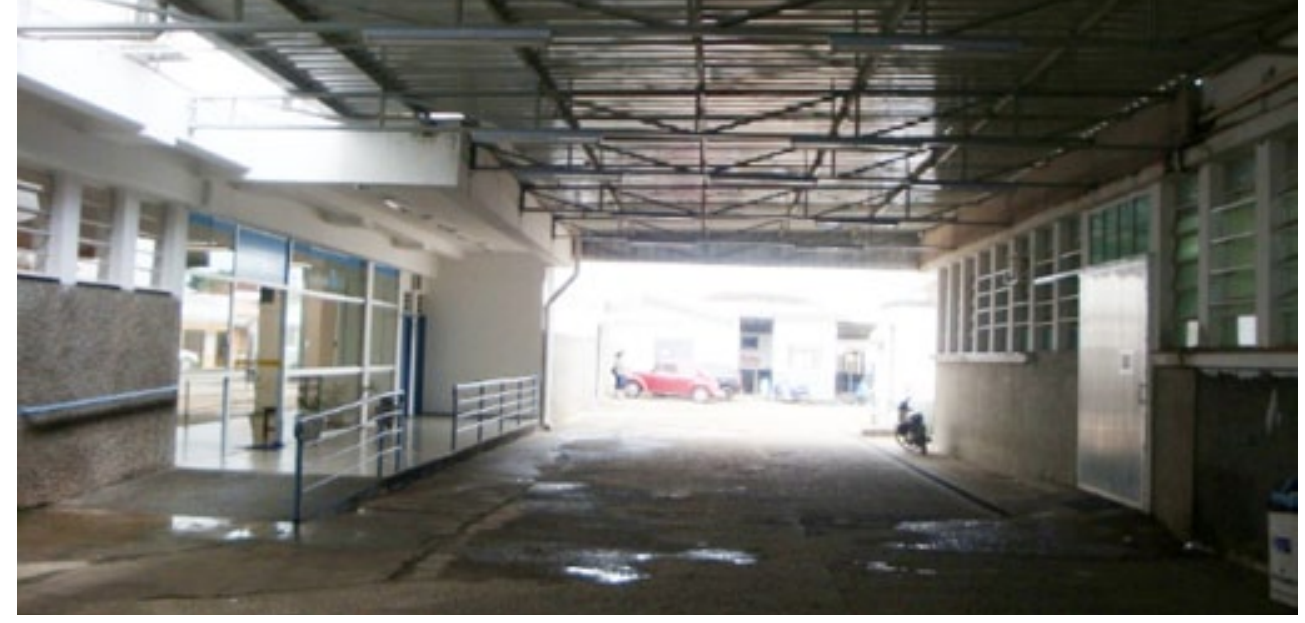

O que se pode concluir é que os conceitos de adequação ao local, nos hospitais novos estão sendo considerados e colocados em prática. Porém, nos hospitais mais antigos, com o é o caso das Santas Casas, tal requisito apresenta dificuldades para ser colocado em prática por dois fatores distintos: pela idade dos estabelecimentos que compromete sua ampliação, que é o caso de Porto Alegre e, no caso de São João da Boa Vista, por simples e estranha despreocupacãa com o requisito. Despreocupação esta que está comprometendo as condições de conforto, segurança e utilização do hospital.

De outra forma, a teoria nos coloca que, para se ter uma adequação ao local, antes da instalação dos estabelecimentos, deve-se fazer uma analisa do terreno, seu entorno e sua relação com a cidade; avaliação de sua topografia; e análise deste terreno com relação à sua condicão de adequações e ampliações futuras do estabelecimento que nele se instalará, ou seja, o arquiteto tem papel fundamental nesta etapa de definições. Na prática, o que verifica-se é que tais estudos foram elaborados e os estabelecimento analisados são adequados aos seus respectivos locais tanto nos mais antigos que existem e funcionam perfeitamente até os dias atuais, como nos mais novos onde percebe-se tal preocupação.

5.4.2 O projeto deve resultar de um estudo funcional e técnico do problema

Conforme já colocado, agora de maneira objetiva, o requisito em questão compreende por estudo funcional do problema, buscar-se ao se projetar, entender qual a vocação que se espera de um determinado projeto, e preferencialmente buscar ter ao lado da equipe de arquitetura profissionais da área da saúde ou mesmo uma equipe multidisciplinar conhecedora das práticas da especialidade a ser projetada.

Com finalidade ilustrativa, a seguir comentário de TOLEDO a respeito da questão da parceria entre equipe médica e equipe de arquitetura muito presente nos trabalhos de João Filgueiras Lima - Lelé.

Muito mais importante que tudo isso é compreender que a qualidade espacial encontrada nos hospitais da Rede SARAH não se deve apenas ao excepcional talento de Lelé, nem à sua capacidade de dominar de ponta a ponta o processo projetual e construtivo de seus hospitais e, sim, à integração que neles se verifica entre os procedimentos terapêuticos e as soluçōes arquitetônicas.

Esta integração, construída a partir de um trabalho conjunto entre o arquiteto, o médico, a enfermeira, o paciente e os demais agentes que fazem funcionar o hospital, é fruto, principalmente da grande sintonia entre o médico Alóisio Campos da Paz, o criador da Rede SARAH, e Lelé.

Nas enfermarias, a intimidade que encontramos é de outra ordem, isto é, entre a arquitetura e os procedimentos terapêuticos. Nelas, os pacientes circulam livremente, deslocando-se, sempre que desejam para os grandes terraços que parecem convidá-los para o banho de sol ${ }^{1}$

Nas análises práticas, antes de analisar o requisito em si, vale ponderar a respeito de suas especialidades

O Hospital Escola Municipal de São Carlos terá, quando finalizado, o perfil de hospital geral; da mesma forma, a Santa Casa de São João da Boa Vista é um hospital geral; o Hospital do Câncer de Barretos é um hospital especializado em tratamento oncológico; e a Santa Casa de Porto Alegre, por ter sete hospitais no seu complexo, reúne tanto hospitais especializados quanto o hospital de atendimento geral. 
No Hospital Escola Municipal de São Carlos, muito da experiência que Lelé tem nos hospitais da rede Sarah, foi utilizada. Em função desta experiência, certamente a relação entre equipe de arquitetura e equipe técnica deve ter ocorrido, porém a análise de sua eficiência ainda não pode ser analisada pelo fato de o complexo ainda não estar pronto.

No Hospital do Câncer de Barretos, embora não se tenha conhecimento da participação quando do início da construção, nos prédios mais atuais este requisito se evidencia. Primeiramente, através de sua implantação racional e que privilegia o bem-estar dos pacientes: em segundo, se evidencia em um dos principais problemas que precisam ser tratados num hospital destinado ao tratamento ao câncer, a auto-estima dos utentes e acompanhantes, que recebe grande atenção e pode ter sua eficiência constatada; ainda, vale lembrar que o hospital foi concebido por um casal de médicos especialistas, ou seja, certamente houve uma integração entre equipe médica e de arquitetura. A equipe de arquitetura inclusive é exclusiva e interna ao complexo, o que traz não somente qualidade técnica como comprometimento e experiência dos usos e procedimentos. De fato, o conhecimento técnico do problema e consequentemente do projeto funcional estão evidentes nesta instituição e certamente contribui para os demais fatores que tornam a instituição uma referência nacional no tratamento contra o câncer.

Na Santa Casa de Porto Alegre, tal análise se torna mais difícil por dois motivos: primeiro, porque a instituição tem aproximadamente 200 anos e muito daquilo que se pretendia, quando de sua instituição, pode ter mudado; depois, porque a instituição é muito ampla e complexa. Ao mesmo tempo em que é mais difícil, a análise também pode trazer resultados mais significativos.

Sua intenção original, quando do início das atividades - o atendimento aos mais necessitados e desprovidos de condição - é até hoje uma realidade. Através do Hospital Santa Rita, o primeiro do complexo, tal atendimento é oferecido até hoje através do atendimento aos usuários do Sistema Único de Saúde. É o grande hospital de atendimento geral do complexo. Os demais hospitais todos são especializados, em oncologia, em neurologia, pneumologia, cardiologia, transplantes e infantil. Este último, embora seja especializado no tratamento pediátrico, pode ser considerado um hospital geral de crianças, inclusive de alta complexidade.

No caso deste complexo, em função principalmente de sua grande dimensão, fica muito claro o controle por parte da arquitetura do conhecimento técnico e funcional dos problemas que, além de ter em cada um dos hospitais sua especificidade, é necessário um amplo entendimento geral para fazer com que o complexo, como um todo, funcione em perfeita harmonia. E isso acontece. Tanto acontece que o complexo é referência em qualidade no atendimento e nos procedimentos, quer seja como um todo quer seja em suas especialidades.

O departamento de arquitetura e engenharia existente no complexo conta ainda com a colaboração do escritório de arquitetura do arquiteto Cassiano Granzotto que há mais de vinte anos tem essa função de colaborador e responsável pelos projetos de reforma e ampliação da Santa Casa.

Neste caso espećfíco, pode-se dizer que a arquitetura não contribui apenas para o funcionamento do complexo. Pode-se certamente dizer que ela é fundamental para garantir seu funcionamento em perfeita harmonia, o que a torna evidentemente grande colaboradora para o sucesso técnico e profissional da instituição.

Na Santa Casa Dona Carolina Malheiros de São João da Boa Vista, conforme já constatado a arquitetura que está sendo realizada atualmente, no processo de revitalização da instituição demonstra erros conceituais. Desta forma sua análise é muito significativa, pois, pode-se analisar a instituição em dois momentos distintos: o original que permaneceu praticamente inalterado até anos atrás e o atual onde fica clara a inobservância da técnica e funcionalidade do problema.

Originalmente, como grande hospital geral da cidade, pode-se dizer que quem a projetou tinha total controle sobre o problema. A Santa Casa contava com um grande eixo central (pavilhão central) destinado à circulação e locação de alguns serviços de apoio (farmácia e radiologia, por exemplo) e pavilhões transversais destinados às internações (distribuídos de maneira racional) e alguns ambientes de apoio como ambulatório, laboratórios, administração, etc. Ainda, separava por pavimentos as especificidades: no térreo os serviços de atendimento ambulatorial e exames no primeiro o centro cirúrgico, UTIs e enfermarias e no terceiro centro cirúrgico obstetrício, maternidade e enfermarias gerais.

Não se pode dizer que originalmente o projeto oferecia uma solução diferenciada, mas conhecedora de suas finalidades e por isso eficiente.

Atualmente, pelo processo de revitalização em que a instituição está passando, nitidamente se nota uma confusão técnica, pois além de não se racionalizar as novas instalações, ainda está acontecendo certo comprometimento das existentes. Tanto pela reforma dos espaços existentes quanto pela confusão generalizada que as novas instalaç̃̃es trazem ao funcionamento do complexo como um todo.

De forma conclusiva, relativamente a este requisito, pode-se dizer que a Santa Casa de São João da Boa Vista em sua concepção original era eficiente, embora limitada em função da idade, demonstrando assim controladora da questão técnica e funcional. Porém, atualmente, com as 
atuais reformas, tal característica se perde quase que por completo.

Então, de forma geral, a análise teórica nos coloca que, para se ter um projeto que resulte de um estudo funcional e técnico do problema precisa-se na fase de projeto, conhecer a fundo quais as necessidades que tais estabelecimentos precisarão, entendendo seu foco de atuação, ou seja, sua vocação; e quando possível trabalhar-se em conjunto com a equipe técnica do estabelecimento, a fim de, através da experiência prática desta equipe, tornar os projetos mais eficientes. Na prática, o que se vê é que de fato tal situação acontece, mas geralmente nos hospitais especializados, como o do câncer ou os hospitais do complexo da Santa Casa de Porto Alegre. De certa forma, os hospitais gerais são normalmente encarados, tanto pela equipe projetista quanto pela equipe técnica como mais comuns, neste aspecto, e assim menos valorizados pelos profissionais envolvidos. Tal situação resulta, obviamente, em menor qualidade final.

5.4.3 Racionalização das circulações e agrupamento de usos e atividades afins

De maneira objetiva, preocupar-se com a racionalização das circulaç̃os e agrupamento de usos e atividades afins, na realidade é buscar tornar o projeto do estabelecimento racional e que, consequentemente ,contribua para o sucesso de diversos requisitos como o auxilio na prevenção à infecção hospitalar, por exemplo.

Ambas as características, racionalização das circulações e agrupamento de usos e atividades afins, estão intimamente ligados. Se não houver um, o outro não tem como existir. Por exemplo, se não houver em um estabelecimento um agrupamento de usos e de atividades afins, muito dificilmente se conseguirá obter uma circulação totalmente racional. O inverso também é verdade, ou seja, de nada adianta se buscar um agrupamento de usos e de atividades afins, se elas não puderem funcionar e interligar-se com circulaç̃̃es racionais.

Sabe-se que tal requisito não é tarefa fácil de ser cumprida. Quando a instalação é nova e ainda não passou por muitos processos de adaptação, até que não se pode considerar de tão difícil alcance, mas, quando se analisa estabelecimentos mais antigos, que tem sua vocação inicial modificada, que já passou por uma série de transformacõos ao longo de sua existência, estabelecer-se ou mesmo manter-se esta racionalização não é tarefa fácil.

Nos estudos práticos realizados, pode ser analisado como tudo acontece.
O Hospital Escola Municipal de São Carlos, pode-se dizer que é referência neste requisito. Tanto na análise da primeira etapa já em funcionamento, quanto na análise do projeto como um todo.

A primeira etapa, que está em funcionamento abrange as áreas de ambulatório, pronto atendimento e exames radiológicos. Esta configuração em si já demonstra um agrupamento de atividades afins eficiente e mais, com o complexo todo em funcionamento, terá seu papel ainda mais ressaltado, pois esta ala consistirá na região de atendimento direto ao público, em função de suas funç̃oses. É de certa forma o elemento que se coloca como uma barreira que separa o público externo que vem ao hospital para procedimentos rápidos (emergência, exames, etc.) daquele que necessitará adentrar as instalações completas como internações, cirurgias, partos, etc.

Se esta unidade tivesse o objetivo de permanecer como hoje está instalada, por si só já seria um exemplo de racionalidade da circulação, pois, claramente existem as circulações técnicas, as circulações de utentes em procedimentos e de usuários comuns. Também seria exemplo de agrupamento de usos e atividades afins, pois todas elas (pronto atendimento, ambulatório e exames) tem íntima relação funcional e física eficiente.

As imagens abaixo demonstram a colocação feita:

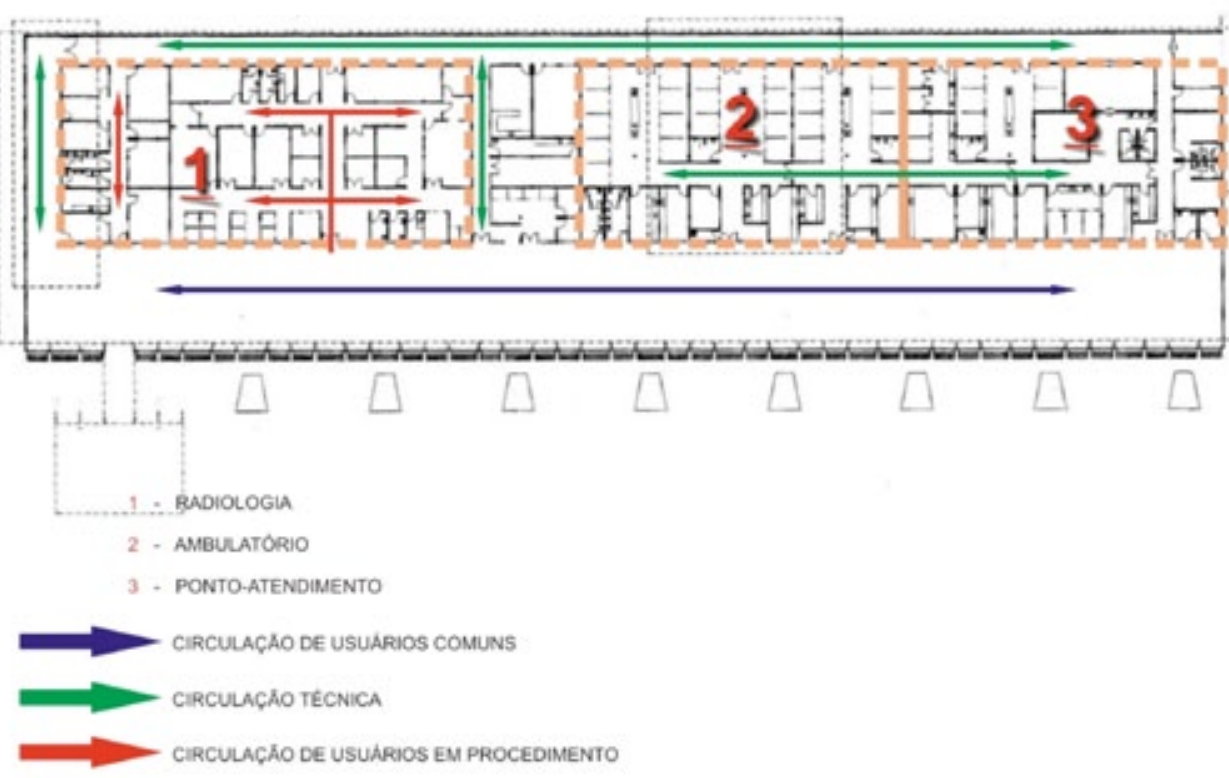

Croqui ilustrativo

da áera em

funcionamento

do Hospital Escola

Municipal de São

Carlos com esquema

das circulações. 


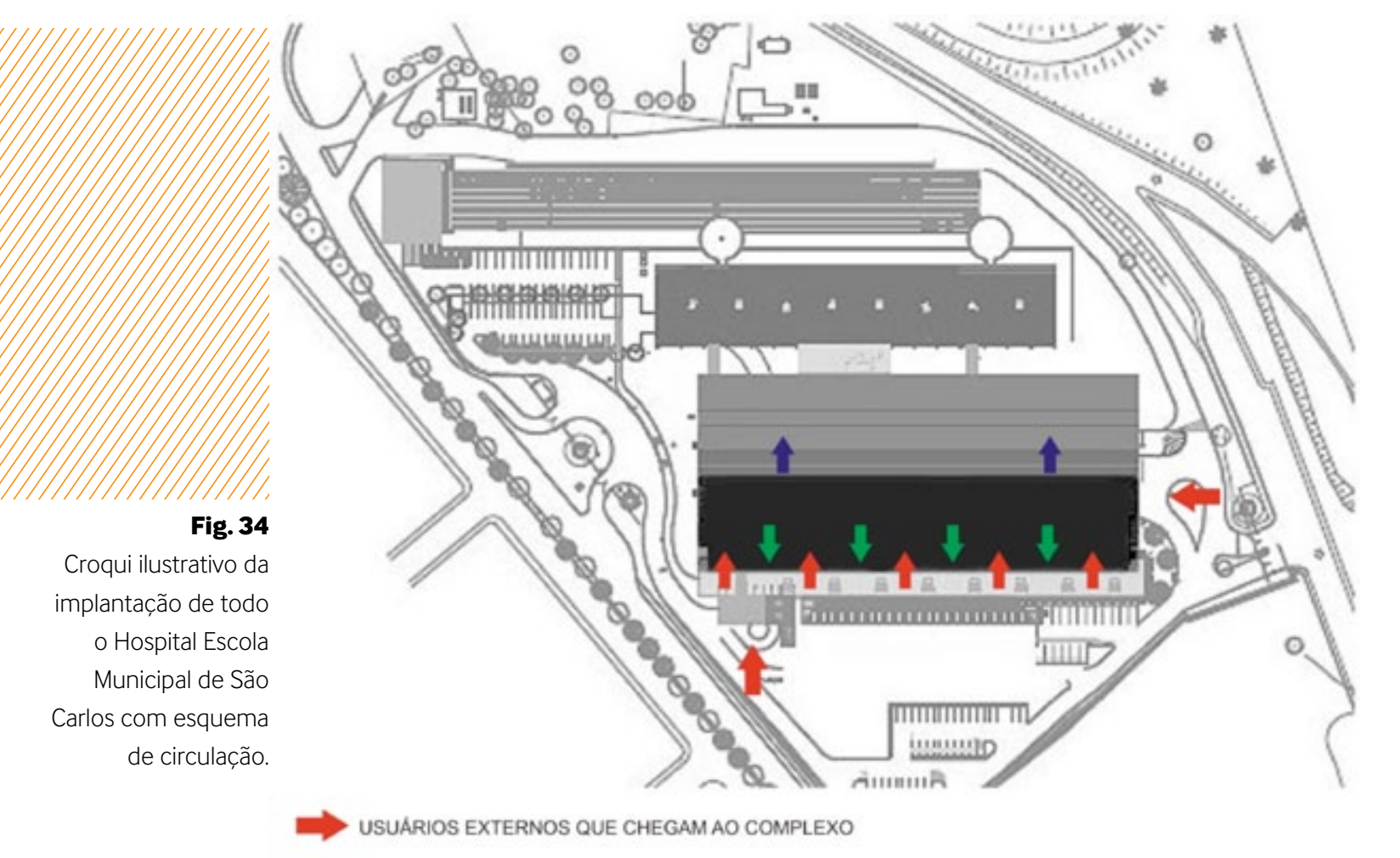

$\rightarrow$ USUARIOS EXTERNOS QUE CHEGAM AO COMPLEXO

$\rightarrow$ usuarios que precisam Utilizar as Instalaçoes completas

$\Rightarrow$ usuarios QUe REToRnAM

Ao se analisar o projeto como um todo, mesmo que de maneira superficial, então sua função e consequente racionalização têm ainda maior sentido e demonstração de racionalidade.

No Hospital do Câncer de Barretos embora o complexo tenha crescido por etapas - e isto fica evidenciado na arquitetura -, de maneira geral o hospital pode ser compreendido em três grandes blocos: o primeiro e mais antigo, que engloba as primeiras construç̃̃es, é destinado aos procedimentos (ambulatório, triagem, exames, cirurgias, radio e quimioterapia, etc.); o segundo, com construç̃es mais atuais, voltado para as áreas de permanência dos utentes (internações adultas e infantis, UTIs) e o terceiro, recém inaugurado, voltado para as finalidades de prevenção e apoio aos médicos (salas privativas, salas de estudo, biblioteca, auditório, etc.).

A seguir, novamente apresenta-se a implantação esquemática para auxiliar no entendimento do que se explica.

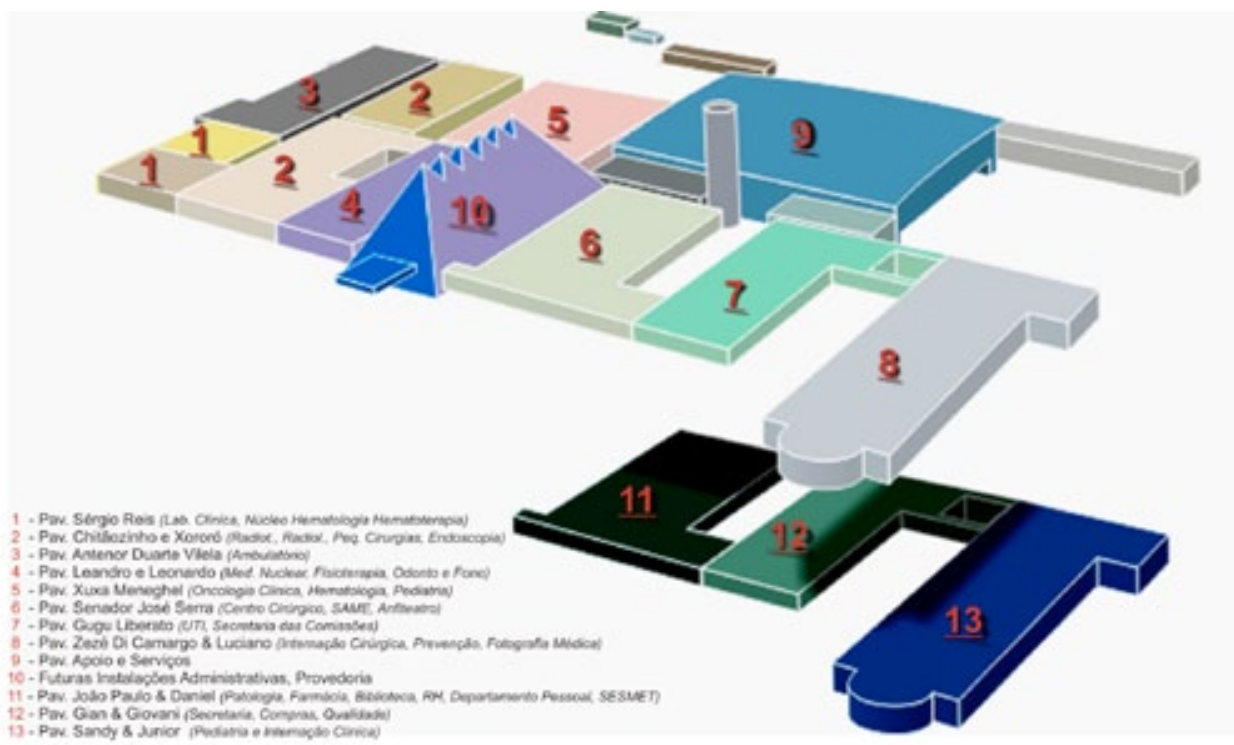

Na implantação, os blocos numerados de 1 a 6 são os citados como pertencentes ao primeiro grupo. 0 mais antigo e voltado para procedimentos. Os blocos numerados por 8 e 12 são de internação adulta e infantil respectivamente e o bloco sete abriga as Unidades de Tratamento Intensivo. 0 terceiro grupo colocado, o mais atual e voltado para fins de prevenção e apoio à equipe médica, não consta da implantação, mas pode ser visto ainda em obras na foto a seguir.

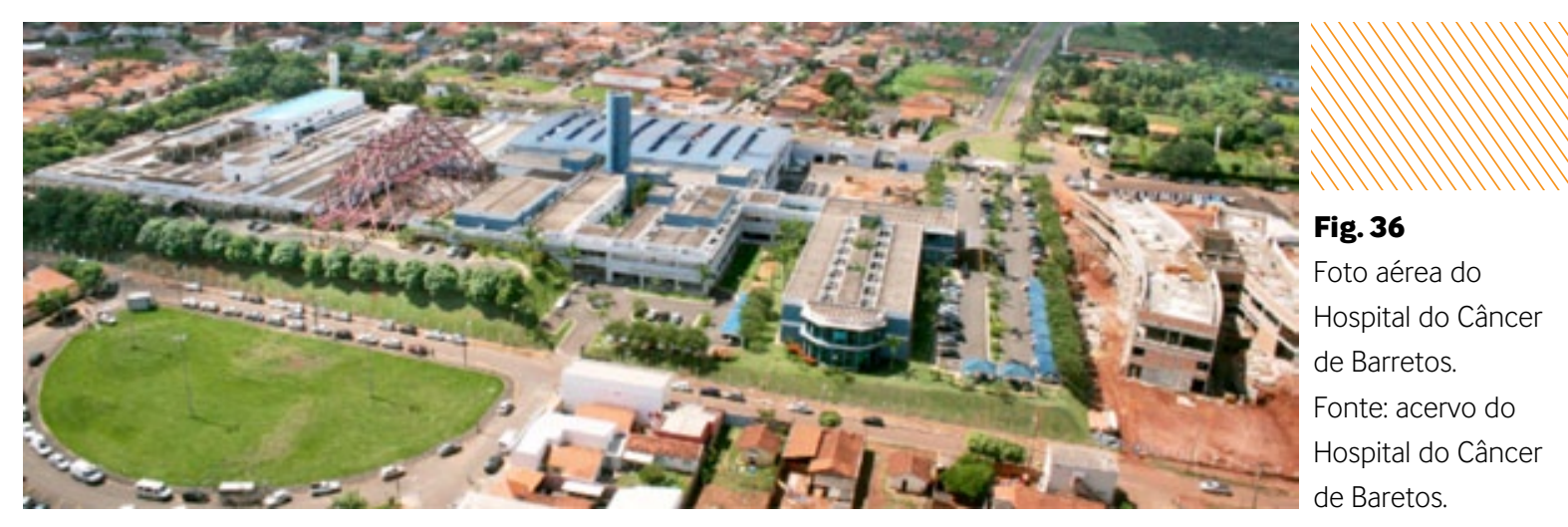

Importante salientar dois aspectos: o primeiro é que as áreas de apoio e serviços (bloco com número 9) e a área do centro cirúrgico (bloco com número 7) encontram-se de maneira centralizada no complexo; o segundo é que existe um eixo central de circulação, por onde tudo, de ponta a ponta, se liga. Fato interessante a colocar é que, nesta circulação central, embora

não seja ela exclusiva para os trabalhadores da saúde e as respectivas circulações técnicas e de
Fig. 35

esquemática do

Hospital do Câncer de Barretos.

Fonte: acervo do

Hospital do Câncer de Barretos. 
apoio, de forma bastante eficiente se separam o fluxo técnico (que fica neste eixo central) e o de pacientes, acompanhantes e usuários comuns, que acontece através das varandas que margeia parte do complexo.
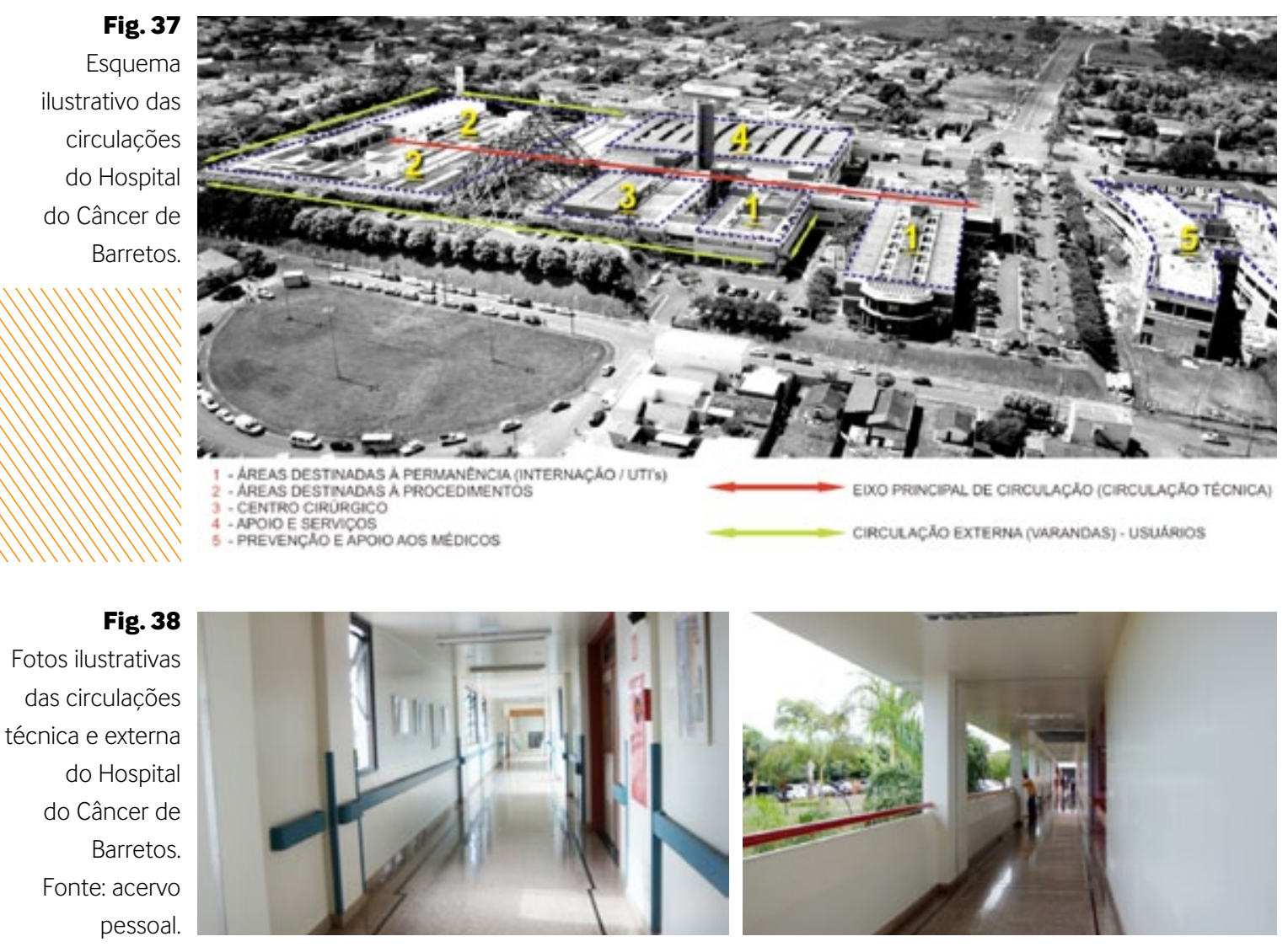

Desta forma, vê-se a distribuição de todo o complexo agrupada por atividades e usos afins, corelacionadas entre si de forma eficiente e uma consequente circulação racional que privilegia a praticidade no eixo central e o bem-estar nas varandas externas destinadas aos usuários não técnicos.

A Santa Casa de Porto Alegre, embora ofereça a implantação mais complexa a ser analisada, em função da quantidade de edificaç̃oes, apresenta um agrupamento de usos e atividades afins e uma circulação bastante eficiente. Pode-se entender o complexo como um todo funcionando da seguinte maneira:

Cada edifício abriga um hospital e cada hospital funciona de maneira independente aos demais, exceto com relação aos serviços de apoio, que são centralizados para todos.
Cada um desses hospitais tem seu agrupamento de usos e atividades afins. Os monoblocos verticais, por exemplo, agrupam os usos por pavimento e os une através da circulação vertical. No Hospital Don Vicente Scherer (especializado em transplantes), por exemplo, no andar térreo se tem todo o serviço de atendimento ao público, como ambulatórios, laboratórios, recepções gerais e triagem; o segundo andar abriga o centro cirúrgico e a central de transplantes; o terceiro pavimento abriga as UTIs (Unidades de Tratamento Intensivo) e terceiro e quarto andares abrigam respectivamente as enfermarias de SUS e convênios e particulares respectivamente e o último pavimento é destinado ao heliporto, importante meio de transportes tanto de emergência quanto de locomoção de órgãos. Fato curioso a ser salientado é que, embora se separem as enfermarias de SUS e particulares e convênios em andares diferentes, tais andares são absolutamente idênticos um ao outro, não apresentando diferenças no tratamento dos utentes de um ou de outro setor. O fato de ser um hospital caracterizado pelo monobloco vertical tem todas as implicações boas e ruins de sua tipologia, mas aqui elas não serão objeto de análise.

A seguir, foto do Hospital Don Vivente Scherer.

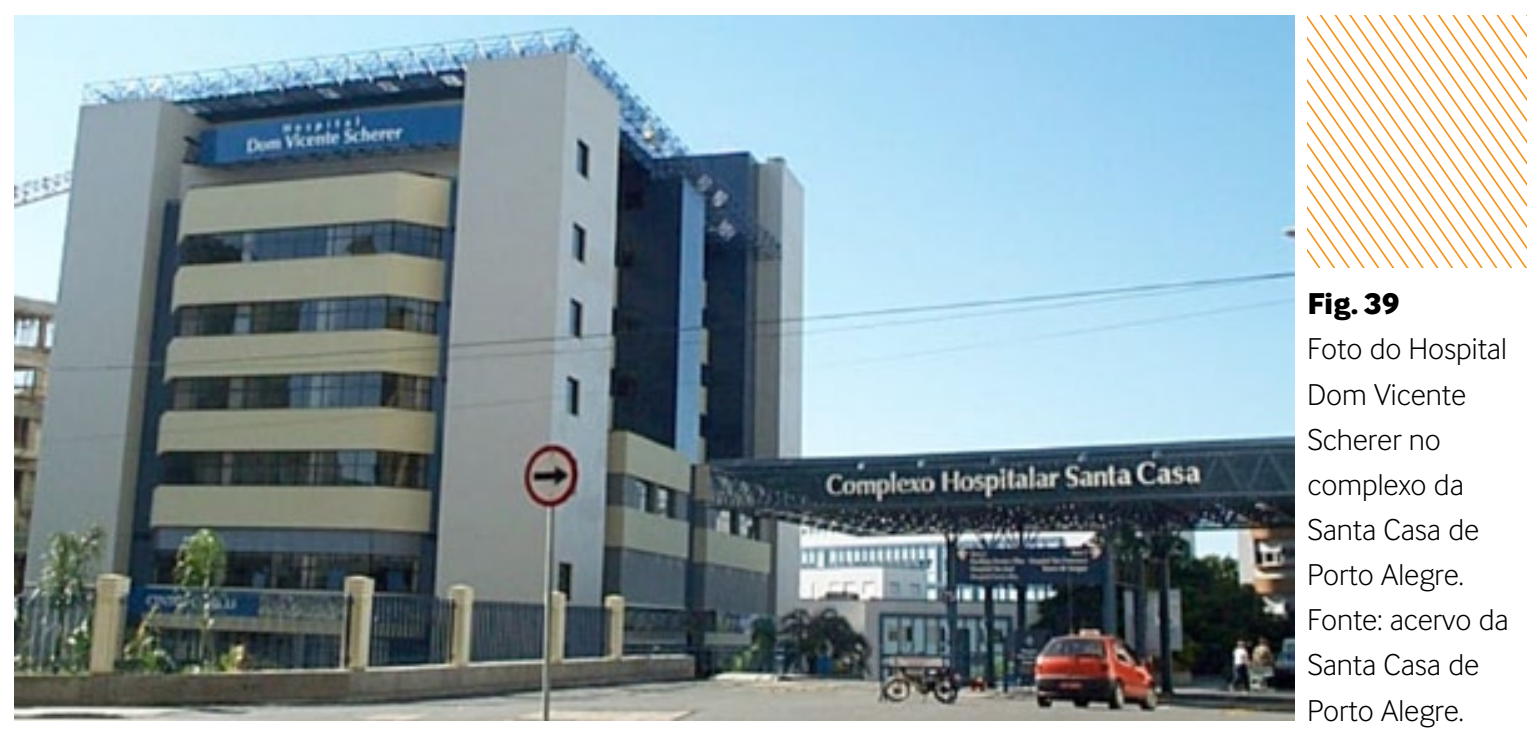

Os hospitais mais antigos do complexo, como o Hospital Santa Clara ,que é o primeiro, tem características diferentes: características do modelo pavilhonar tradicional, com seus agrupamentos de atividades e usos afins distribuídos por alas e uma circulação muito mais desenvolvida no sentido horizontal, também eficiente, mas diferente do modelo vertical dos hospitais mais novos. 0 projeto de ampliação desta unidade em especial torna-se curioso, pois terá em funcionamento dois modelos, uma vez que a nova ala a ser construída será no padrão 
monobloco vertical. Também está no projeto a construção de torres de circulação vertical para atender à estrutura atual, que será reformada para atender às atuais necessidades de usos e conforto oferecido aos utentes, com enfermarias menores, contemplando banheiros, etc.

A seguir, foto do Hospital Santa Clara

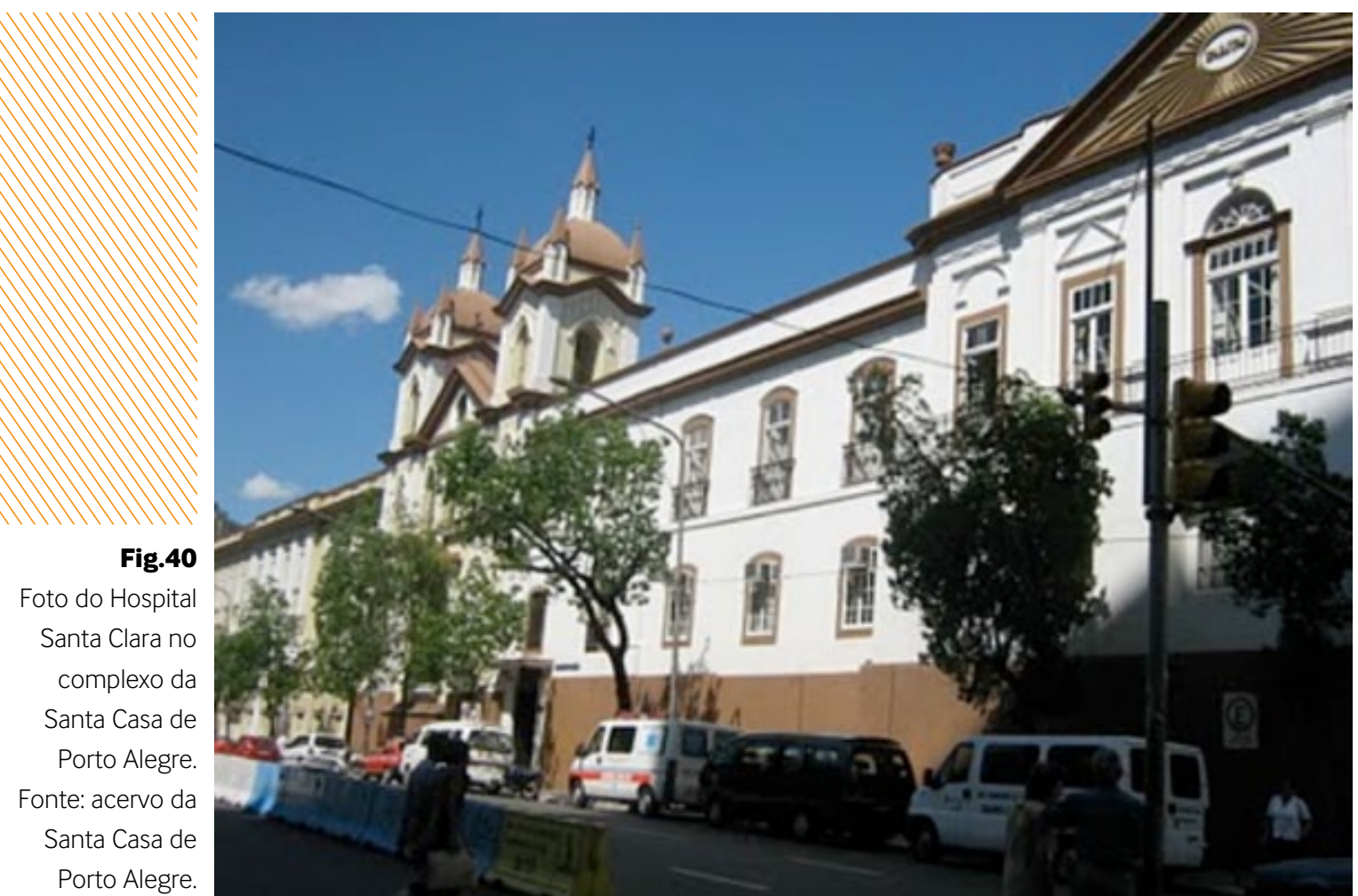

Como já fora colocado, o modelo de implantação do complexo é o modelo chamado funcional orbital, onde todos os hospitais têm comunicação entre si e com a área centralizada de serviços e apoio. Esta comunicação se dá através de passarelas elevadas que unem todos os prédios do complexo. Sistema muito interessante, pois além de unir todos os hospitais fisicamente, de maneira eficiente consegue separar as circulações, pois nessas passarelas somente circulam a equipe técnica, e os utentes com seus respectivos acompanhantes. Desta forma, estabelece-se um agradável e útil passeio por todo o complexo do ponto de vista dos usuários e uma eficiente circulação do ponto de vista técnico. Ficam desta maneira, totalmente isoladas, as circulações gerais para usuários não internos, visitantes, prestadores de serviços, etc. que obrigatoriamente têm que circular pelo térreo por passeio não menos agradável através das praças e áreas livres.
A seguir, fotos que ilustram o descrito.
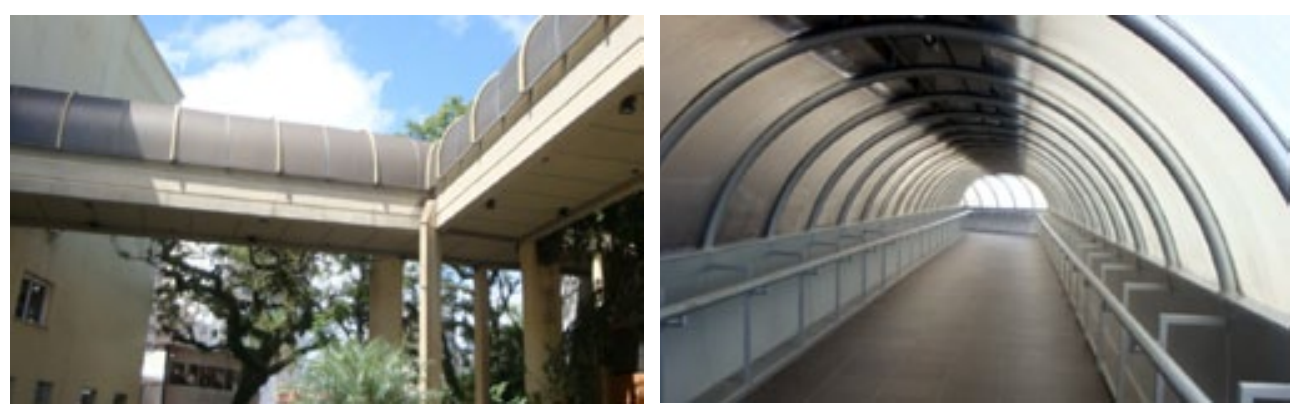

Fig. 41

Fotos ilustrativas das passarelas que ligam os hospitais do complexo da Porto Alegre. Fonte: acervo pessoal.

A Santa Casa de São João da Boa Vista - Dona Carolina Malheiros, originalmente apresenta um modelo de agrupamento de usos e atividades afins e uma circulação bastante eficiente e racional. De maneira sintética tinha-se:

No térreo, o pavilhão frontal do complexo ocupado em uma lateral pelo ambulatório e pronto atendimento, em outra lateral para os exames de apoio, recepção, tesouraria e capela. No centro de tudo, tem-se até hoje a circulação vertical principal. Logo nos fundos, a área destinada à radiologia. Assim, todos os serviços de utilização dos usuários não internos, estão nesse térreo, como ilustra o esquema abaixo.

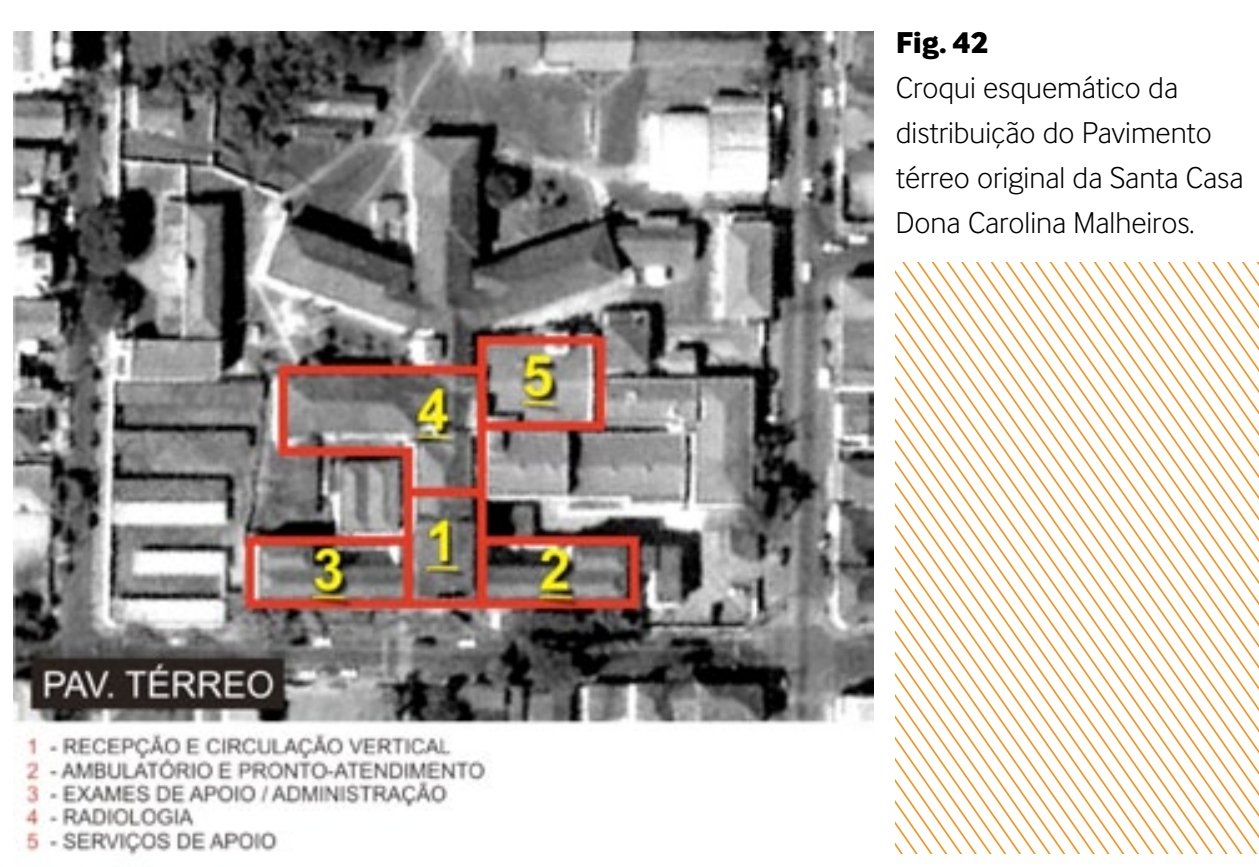


No primeiro pavimento, tinha-se o grande espaço de compatibilização entre as circulações vertical e horizontal; no pavilhão frontal estavam as enfermarias. No segundo pavilhão, tinhase de um lado os serviços de apoio, de outro, a provedoria e, ao fundo, o centro cirúrgico ladeado pelas enfermarias de UTI (Unidades de Tratamento Intensivo) e enfermarias gerais. Tudo conforme mostra o esquema a seguir.

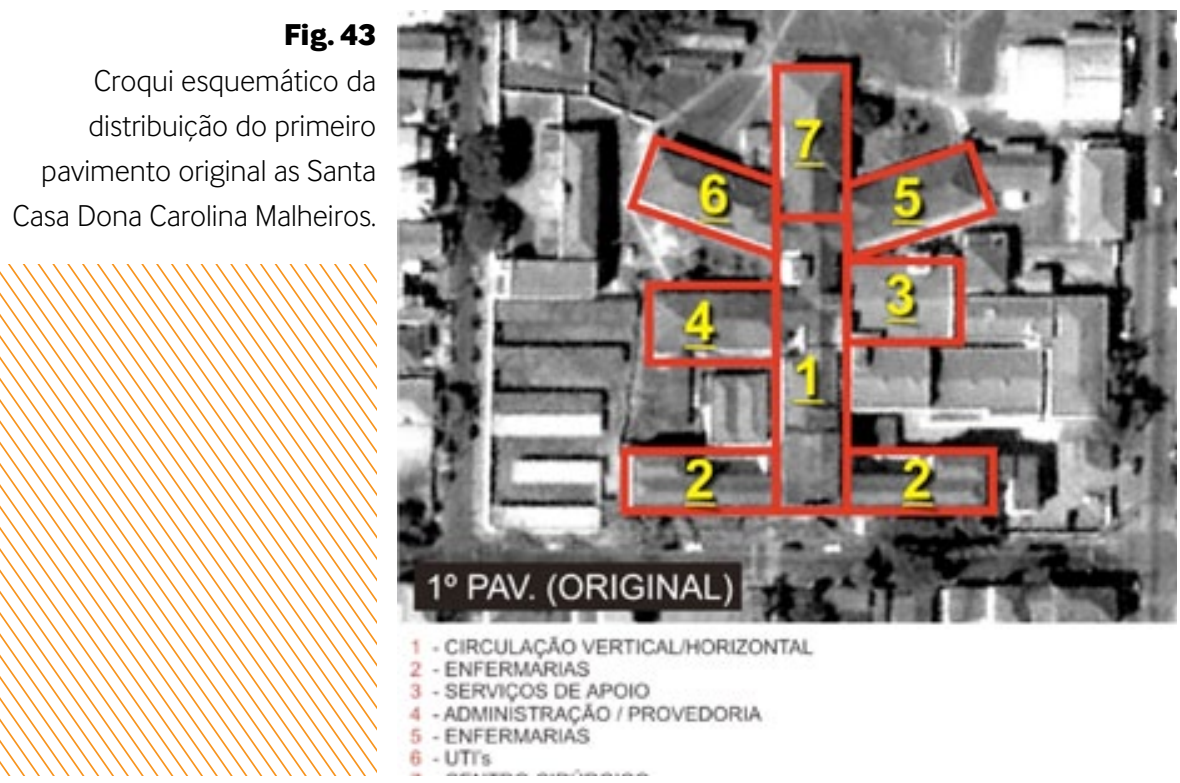

No segundo pavimento tinha-se o grande espaço de circulação. No segundo pavilhão estavam de um lado senviços de apoio e do outro, enfermarias; ao fundo, tinha-se o centro cirúrgico obstetrício ladeado pelas enfermarias da maternidade. Conforme mostra o esquema a seguir.

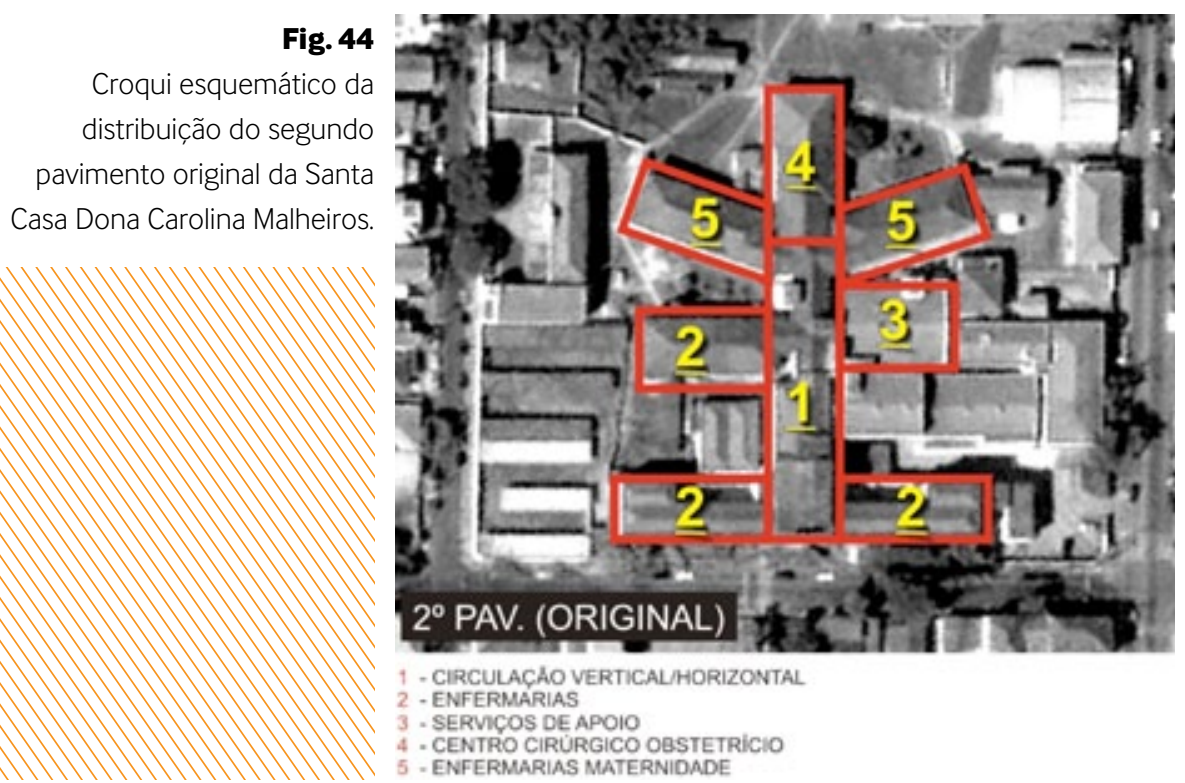

Atualmente, em função do processo de revitalização pelo qual está passando a instituição, tem-se o edifício principal em sua maior parte mantido, o que é bom. Porém, novos anexos estão sendo construídos para abrigar novos serviços de atendimento ao público, anteriormente oferecidos somente de maneira interna, como laboratórios, fisioterapia, etc. Isso vem trazendo ao ambiente, como um todo, certa confusão arquitetônica, pois nesta áreas não existe mais um agrupamento de usos e atividades afins e consequentemente a circulação racional buscada também não existe. Ainda mais, estas construções atualmente ocupam espaços anteriormente vazios, destinados a áreas de ventilacão, jardins, etc., o que hoje deixa praticamente de existir. começando a comprometer a condição de conforto dos edifícios, como um todo.

A seguir, implantação esquemática, demonstrando a quantidade de novos anexos e suas respectivas localizações.

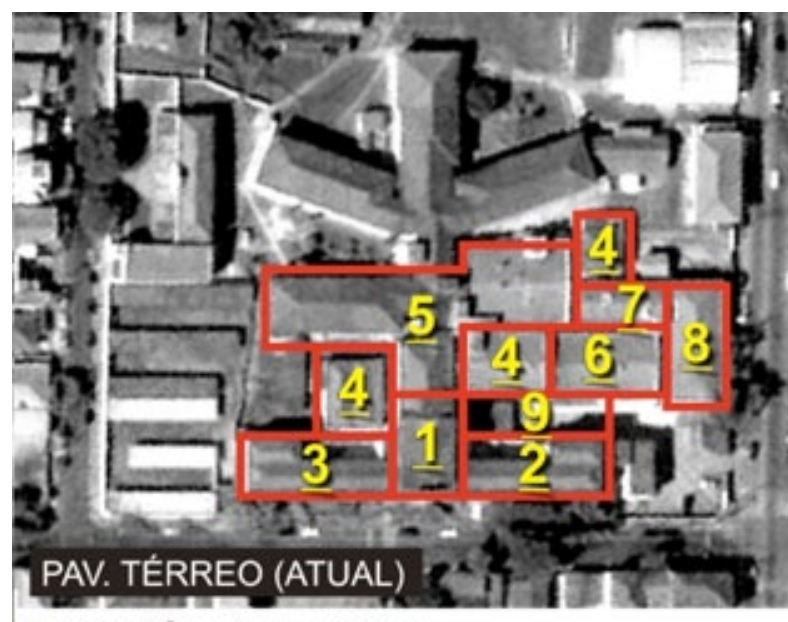

Croqui esquemático de

distribuicão do pavimento

térreo atual da Santa Casa

Dona Carolina Malheiros.

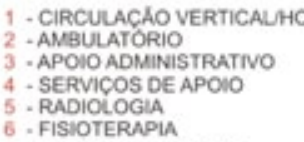

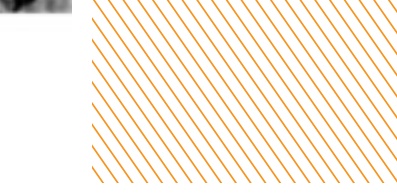

interferências acontece atualmente

mento uma quantidade menor de interferencias acontece atualmente construção de alguns anexos às áreas construídas no térreo e modificação dos usos existentes para as enfermarias.

As enfermarias do pavilhão frontal, reformadas, são divididas em masculinas e femininas e as enfermarias do segundo pavilhão foram totalmente remodeladas e receberam um aumento de decoração e certos equipamentos de luxo, como ar condicionado, TV a cabo, internet sem fio, etc., para atender especificamente os usuários de planos de saúde e particulares. Ao fundo, tudo continua como anteriormente: centro cirúrgico ladeado pela UTI (unidade de tratamento intensivo) totalmente reformada, por um lado e enfermarias gerais pelo outro lado. 0 esquema abaixo ilustra o que foi exposto. 


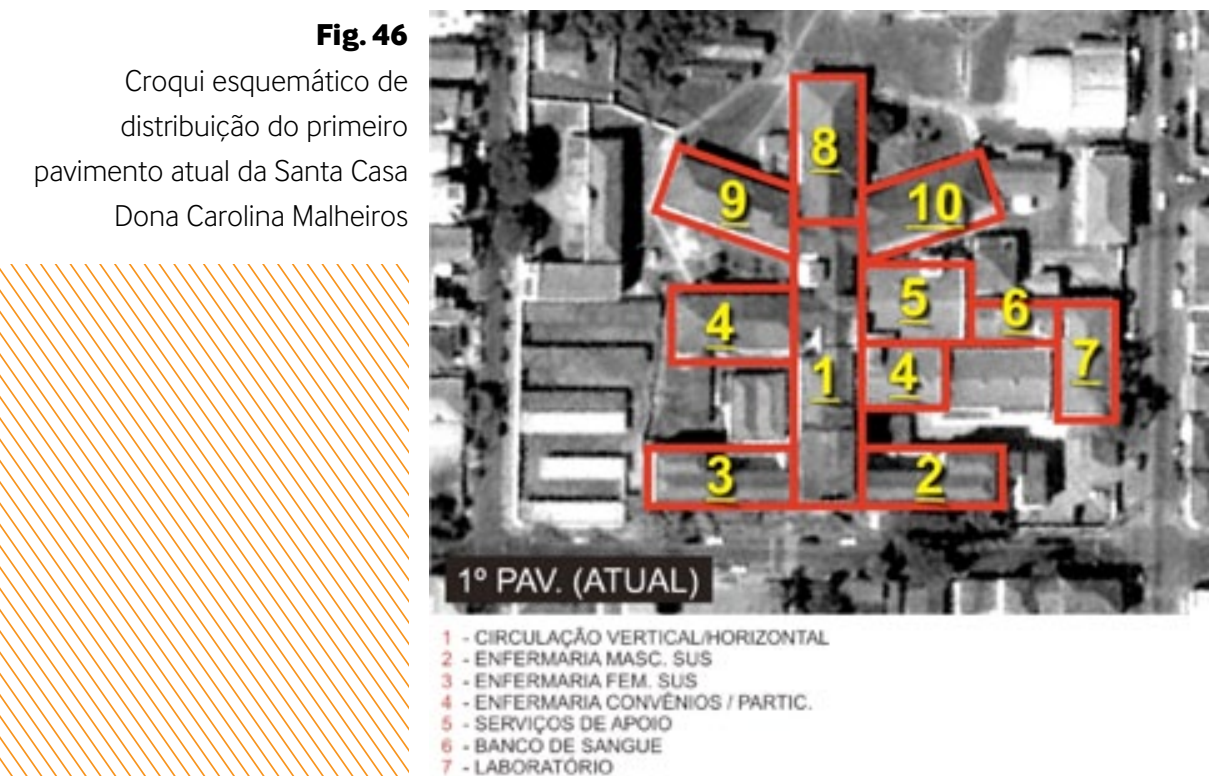

No segundo pavimento muito pouca coisa mudou. Na verdade o que está acontecendo atualmente é uma reforma nos acabamentos em geral dos leitos destinados à maternidade. Porém nada de conceitual está sofrendo alteração. A seguir, ilustração de como ficou a distribuição atual

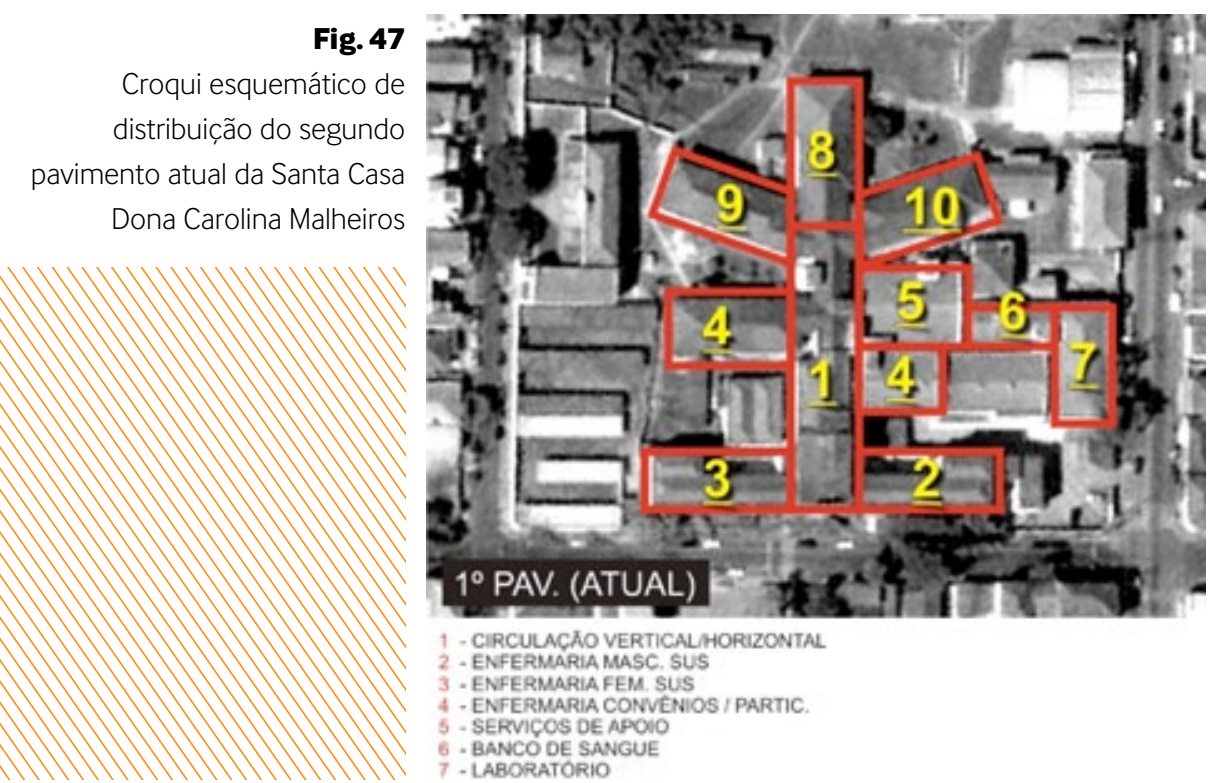

De maneira geral, o requisito em questão na teoria pode ser considerado como uma das maneiras mais eficientes de se tornar um estabelecimento racional como um todo, o que se verifica na prática. Pode-se dizer que tal requisito exerce, na teoria, grande percentual no quesito racionalizaç̃o total dos estabelecimentos. Na prática, o que se percebe, é que esta preocupação é bastante presente em qualquer estabelecimento assistencial de saúde. Não se pode concluir o porquê exato, mas na verdade, racionalizar circulações e agrupar usos e atividades afins representa racionalização de tudo pois, além de garantir melhor segurança nos procedimentos, representa economia de tempo com locomoção de pessoal e equipamentos, de espaço por exigir menores áreas de circulação já que são eficientes: economia financeira em geral que é consequência da economia de tempo e espaço; e assim por diante. Enfim, este requisito que na teoria representa um projeto racional, na prática representa racionalidade ou pelo menos influência na racionalidade de quase tudo que acontece no estabelecimento, o que torna tal requisito como sendo uma meta a ser atingida sempre, em todos os aspectos e formas, tornando-se desta maneira uma necessidade natural e corriqueira, para não dizer vital.

\subsubsection{Auxilio na prevenção à infecção hospitalar}

Trata-se de tema corriqueiro nos estabelecimentos em funcionamento, mas é preciso entenderse como a arquitetura pode contribuir na prevenção à infecção hospitalar.

Partindo-se do princípio de que o arquiteto projetista pode muito contribuir para combatê-la, a abordagem teórica salienta alguns tópicos: racionalização dos fluxos e distribuição dos ambientes e utilização da luz natural solar como uma das melhores formas de prevenção à infecção hospitalar. Pode buscar entender-se, na prática, o que de fato está acontecendo nesta questão.

Obviamente há inúmeras abordagens sobre a prevenção à infecção hospitalar, mas não cabe a esta pesquisa analisar aqueles não relacionados à arquitetura.

Como este requisito está intimamente ligado ao anterior, se for possivel classificar-se os hospitais em análise a partir de sua racionalidade, como eficientes ou não, muito facilmente se consegue concluir no que a arquitetura, nestes casos, consegue contribuir para o auxílio na prevenção da infecção hospitalar.

No Hospital Escola Municipal de São Carlos, como se concluiu que o agrupamento de usos e atividades afins é racional contribuindo inclusive para uma circulação e distribuição de fluxos mais eficientes tanto na área instalada atualmente quanto nas futuras instalações, então, pode-se afirmar que a arquitetura em muito contribui para o sucesso da prevenção à infecção hospitalar. Claro, como já colocado, não é a arquitetura a maior ou única responsável por esta prevenção, mas naquilo que ela pode oferecer contribui beneficamente, como neste caso. 
Tal situação se repete tanto no Hospital do Câncer de Barretos quanto na Santa Casa de Porto Alegre, ou seja, naquilo que a arquitetura pode contribuir para beneficiar a prevenção à infecção hospitalar, ela o está fazendo.

Já na Santa Casa Dona Carolina Malheiros a situação é um pouco diferente. Duas situações preocupam: a falta de racionalização dos agrupamentos de atividades e da circulação e a consequente diminuição da iluminação natural em parte dos ambientes, em especial nas enfermarias destinadas a convênios e particulares onde as janelas passam boa parte do tempo fechadas, uma vez que não oferece o lado externo, nenhum atrativo aos utentes nesta região de internados.

Teoricamente, o arquiteto projetista tem em suas mãos grande poder de influenciar neste requisito, através da racionalização do projeto, das precauções com as diversas instalações e usos, etc. Na prática, o que se vê é que esta preocupação é uma constante em qualquer estabelecimento assistencial de saúde. Em geral, pouco valor se dá ao que a arquitetura pode oferecer, ou seja, preocupa-se atualmente muito mais com os procedimentos, a higienização, do que com a arquitetura. Fato esse se dá porque a contribuição que a arquitetura pode dar a este requisito, na verdade acontece em projeto e não na prática. Na prática, resta aos profissionais da área da medicina tomarem suas precauções.

\subsubsection{Flexibilidade dos ambientes}

Evolução é um conceito muito presente na vida dos Estabelecimentos Assistenciais de Saúde - EAS, pois com a cada vez mais rápida evolução das técnicas e tecnologias da medicina atual, essa evolucão torna-se indispensável nas instalaç̃es físicas desses locais.

Flexibilidade é o requisito que possibilita ao edifício sua evolução sem limitá-la, ou seja, é o requisito que confere ao hospital a capacidade de permitir sua adequação conforme 0 desenvolvimento tecnológico. Ele faz com que a instalação física não seja um obstáculo a ser superado nas constantes evoluções, mas sim um forte aliado delas.

Com este raciocínio, os estabelecimentos em estudo podem ser em dois grupos: um primeiro formado somente pelo Hospital Escola Municipal de São Carlos e um segundo formado pelas Santas Casas de São João, de Porto Alegre e o Hospital do Câncer de Barretos.

O Hospital Escola Municipal de São Carlos, primeiro por ser projetado por João Filgueiras Lima, que reconhecidamente já utiliza tal artifício em seus projetos, e, em segundo, por ser o mais atual de todos em estudo, releva-se o que mais investe neste requisito. É um hospital que tem uma modulação estrutural que permite diversos usos e que poderia inclusive ser motivo de discussão específica. Tal modulação inclusive é totalmente independente dos painéis de vedação, em especial os internos, o que confere absoluta liberdade e flexibilidade de usos. E para finalizar a escolha do material empregado: paredes internas de gesso acartonado estruturado, que na verdade é uma espécie de divisória com alta performance e qualidade e que confere ao ambiente qualidade e liberdade, pois podem facilmente ser removidas.

São estes aspectos todos juntos, modulação da estrutura, independência da estrutura com relação aos painéis de vedação e material utilizado, que conferem a esta unidade o status de mais flexível dentro das unidades estudadas.

Os demais têm também características em comum: apresentam edifícios construídos em épocas diferentes, e certamente os materiais utilizados atualmente não estariam disponíveis à época das respectivas construç̃̃es; passam, entretanto, por constantes reformas de adaptação e de ampliação.

Ao se reformar estruturas antigas, em todos os casos, uma boa surpresa tem se revelado: modulação da estrutura e das aberturas, o que muito facilita a adequação aos novos espaços. Obviamente o material empregado na época da construção inicial (alvenaria) não permite fácil adaptação, mas por ser independente na maioria dos casos da estrutura, permite certa flexibilidade e capacidade de adequação. Obviamente, todos os espaços novos que estão sendo reformados, já empregam materiais atuais que no futuro permitirão maior facilidade de reforma e adequação. Já os prédios atuais, todos buscam a utilização de materiais que têm esta preocupação e a estrutura independente, o que muito facilita este processo.

De fato, embora haja estudos sérios que questionem a viabilidade da flexibilidade nas construções, a realidade brasileira demonstra, a partir das instituições escolhidas, que tal conceito é um requisito viável e atualmente muito utilizado pelas instituições.

Este requisito atualmente tem grande relevância na área médica, em função dos grandes avanços com velocidades impressionantes. Na teoria, tal requisito é responsável por não impedir a evolução da medicina e suas técnicas e tecnologias e garantir que o edifício seja sempre capaz de se revitalizar, com facilidade e rapidez. Na prática, a flexibilidade já acontece nos prédios atuais mas muito provavelmente está acontecendo pelo fato de existirem grandes dificuldades tanto técnicas quanto financeiras para se adaptar os edifícios antigos ao novos moldes. Embora muitas vezes a construç̃a de edifícios novos seja a melhor solucão, financeiramente as 
instituiç̃os são obrigadas a se adaptarem nas dependências existentes, porém não podem deixar de evoluir tecnicamente. Desta forma, a flexibilidade se impõe cada vez mais. Com ou sem planejamento.

\subsubsection{Preocupações com o conforto ambiental}

Visando-se proporcionar a sensação de bem-estar e conforto aos usuários (utente, funcionário, acompanhante, visitante, etc.) de um Estabelecimento Assistencial de Saúde, existe a preocupação da arquitetura com conforto ambiental (térmico e visual entre outros não abordados nesta pesquisa). Por conforto térmico e visual entende-se a preocupação com a ventilação natural e artificial, com a iluminação natural e artificial, com o tratamento acústico e com a utilização de cores (aqui, não com fins terapêuticos).

Desta forma, ao se analisar os ambientes em estudo, buscar-se-á verificar:

- se a utilização da ventilação natural e artificial está sendo feita corretamente, ou seja, de maneira complementar e não substitutiva. Sabe-se que muitas vezes, por ter aparato tecnológico que garante o conforto ambiental interno dos edifícios, a arquitetura deixa de se preocupar com tais elementos de extrema importância, ainda mais em ambientes hospitalares;

- se a utilização de iluminação natural e artificial está sendo feita corretamente, ou seja, também de maneira complementar e não substitutiva. A iluminação artificial deve sim ser utilizada, mas como complemento à natural, para garantir maior segurança a procedimentos, permitindo que estes procedimentos possam ser executados de forma ininterrupta, além de proporcionar qualidade visual aos ambientes.

- se há preocupação com a utilização de cores nos ambientes. A utilização de cores, ainda que sem fins terapêuticos, tem forte influência sobre o ser humano e em muito pode contribuir para a qualidade do ambiente.

Partindo-se para as análises práticas, busca-se verificar se tais elementos colocados fazem-se presentes nos ambientes estudados e como sua utilização é abordada.

No Hospital Escola Municipal de São Carlos, a utilização de ventilação natural em conjunto com a artificial apresenta grande harmonia. Embora os elementos utilizados por João Filgueiras Lima neste hospital sejam eficientes, tal utilização tão presente nos outros hospitais trouxe para este caso específico um problema: em função da grande quantidade de queimadas na área rural no entorno da cidade, o que se percebia é que muitas vezes a fuligem gerada pelas queimadas acabava por ser transportada para dentro do estabelecimento, comprometendo assim sua salubridade. Tal situação, segundo o engenheiro responsável pela fiscalização da obra, foi sanada com a instalação de telas nas aberturas de ventilação dos grandes sheds.

Colocando-se estes problemas como solucionados e à parte, os ambientes internos parecem ser bastante agradáveis, confortáveis e providos de sistema de controle desta ventilação através dos forros retráteis, que permite total controle sobre a situação da ventilação em cada ambiente. Como neste caso a ventilação natural é reconhecidamente eficiente, fica então a necessidade de instalação de equipamentos ar-condicionado apenas nas áreas que dela necessitam, como as salas dos equipamentos de imagem, a de tomografia e as salas de cirurgia.

Com relação à utilização de iluminação natural e artificial, esta situação é bem parecida. Através das áreas de iluminação zenital, obviamente muito bem distribuídas em função da insolação, garante-se aos ambientes total qualidade e controle sobre ela, ficando a cargo da iluminação artificial somente a complementacão tanto para procedimentos, como para os momentos em que a luz natural não existe ou é insuficiente.

O forro retrátil translúcido tem, também, papel de controle na questão da iluminação natural. Relativamente ao ambiente de entrada, o saguão principal de acesso e de espera, este tem ainda grandes planos envidraçados o que muito soma à qualidade do ambiente como um todo, pois integra o interior ao exterior e traz para dentro do ambiente o paisagismo e a água do espelho de água frontal, mas tais assuntos serão motivo de discussão mais adiante.

Com relação à utilização de cores, João Filgueiras Lima neste hospital praticamente não a utiliza. 0 que se nota são elementos coloridos pontuais, como por exemplo o ambulatório infantil decorado com detalhes de motivos infantis coloridos. Nos demais ambientes, nada de cor é utilizado.

No Hospital do Câncer de Barretos, a ventilação natural somente é utilizada nas áreas de uso público, ou seja, nas varandas e salas de espera externas. No restante dos ambientes há a utilização de ar condicionado. Parece ser exatamente em função do fato de a arquitetura, por saber utilizar estes aparatos tecnológicos, ter aberto mão da qualidade interna do ambiente. A consequência direta desta postura é o aumento de custo, tanto com relação ao consumo de energia elétrica quanto com relação à limpeza e manutenção dos equipamentos, fato este preocupante nos ambientes hospitalares, pois a utilização é continua. Obviamente, há os locais onde sua utilização se faz necessária e tais ambientes representam praticamente metade da área de implantação do complexo, porém a implantacão como está em fase de elaboração poderia permitir melhor condição de ventilação natural a todos os ambientes possíveis, o que traria muito mais qualidade para os usuários principalmente para os utentes. 
Fotos que ilustram as varandas de circulação externa, nas quais a ventilação natural traz muito conforto e agradabilidade aos usuários.

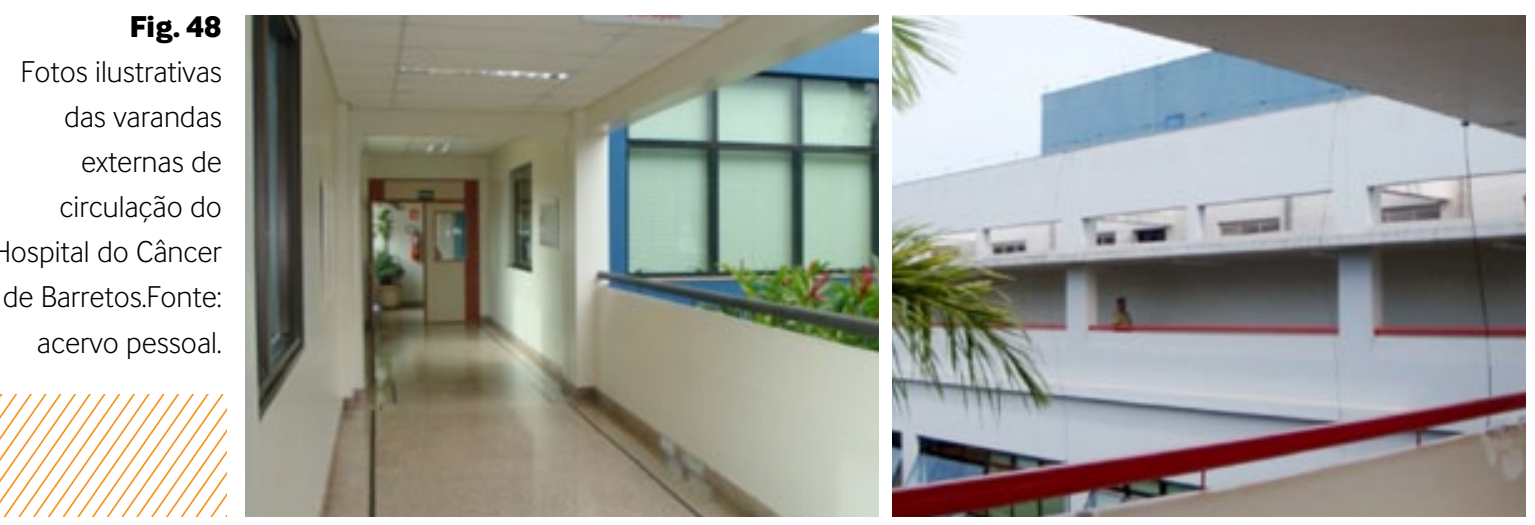

Com relação à iluminação natural e artificial, de forma geral, parece estarem elas sendo utilizadas de forma racional. Todos os ambientes praticamente contam com iluminação natural e, desta forma contam com a artificial para complementação. Em todas as áreas de espera tal condição oferecida é muito boa, tornando os espaços agradáveis inclusive com a utilização de iluminação artificial como decoração, valorizando painéis e cores utilizadas. Em particular nas enfermarias, nota-se a presença de brises nas janelas, artifício muito eficiente no controle da iluminação natural, pois permite controle sobre ela de maneira a não permitir sua entrada no ambiente em excesso e também não deixar que falte quantidade de luz natural. Neste aspecto, pode-se considerar o hospital muito eficiente. A seguir, algumas fotos que ilustram o que foi colocado.

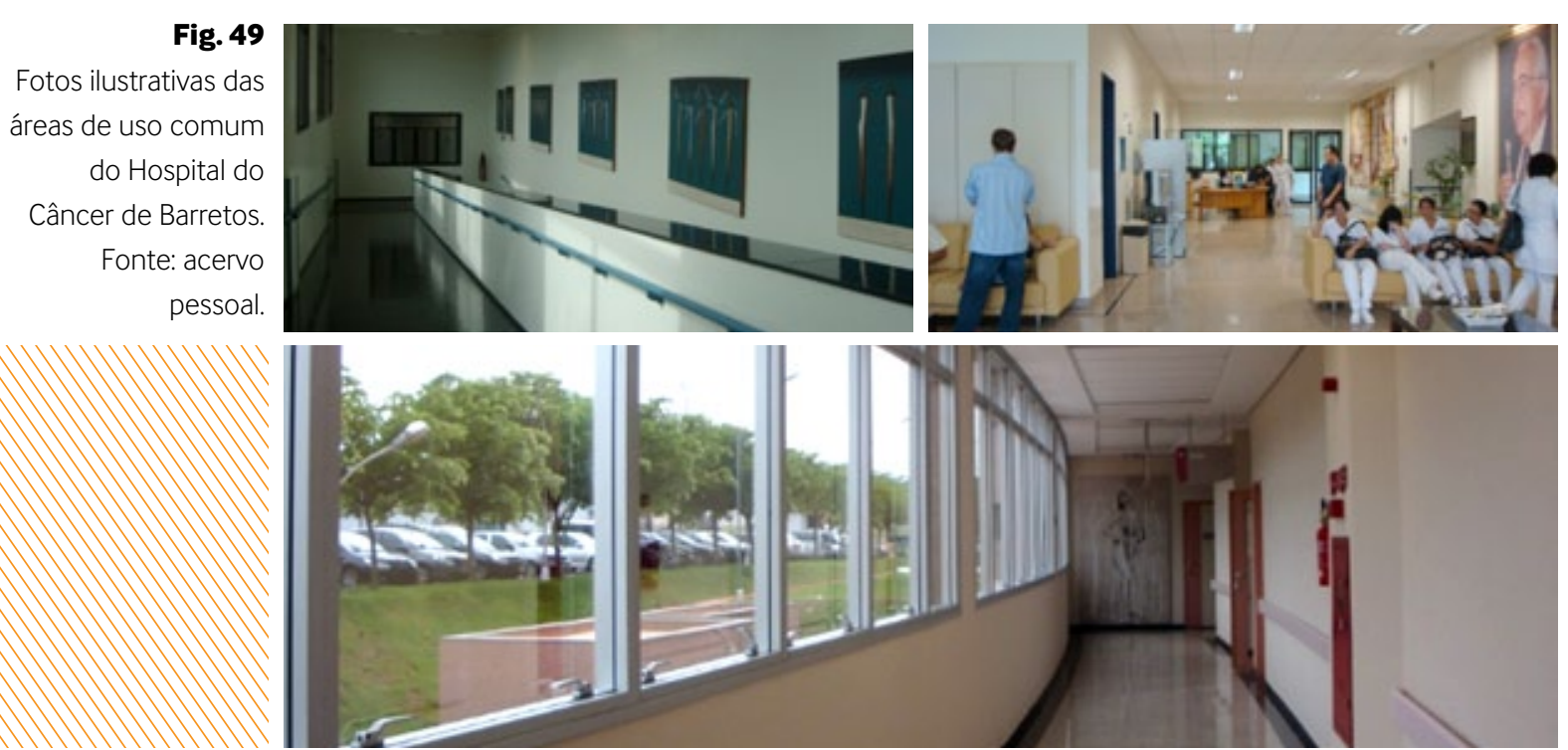

Com relação à utilização de cores, é um artifício muito utilizado neste hospital, tanto interna quanto externamente. Para deixar os ambientes, principalmente as esperas e circulaç̃oes, mais agradáveis, o hospital conta com a utilização de cores e quadros, muitas vezes coloridos. Nitidamente não há um estudo para esta utilização, mas sim uma boa intenção que efetivamente traz conforto visual aos ambientes. Neste quesito, também se pode considerar este hospital eficiente. Abaixo algumas fotos ilustrativas.

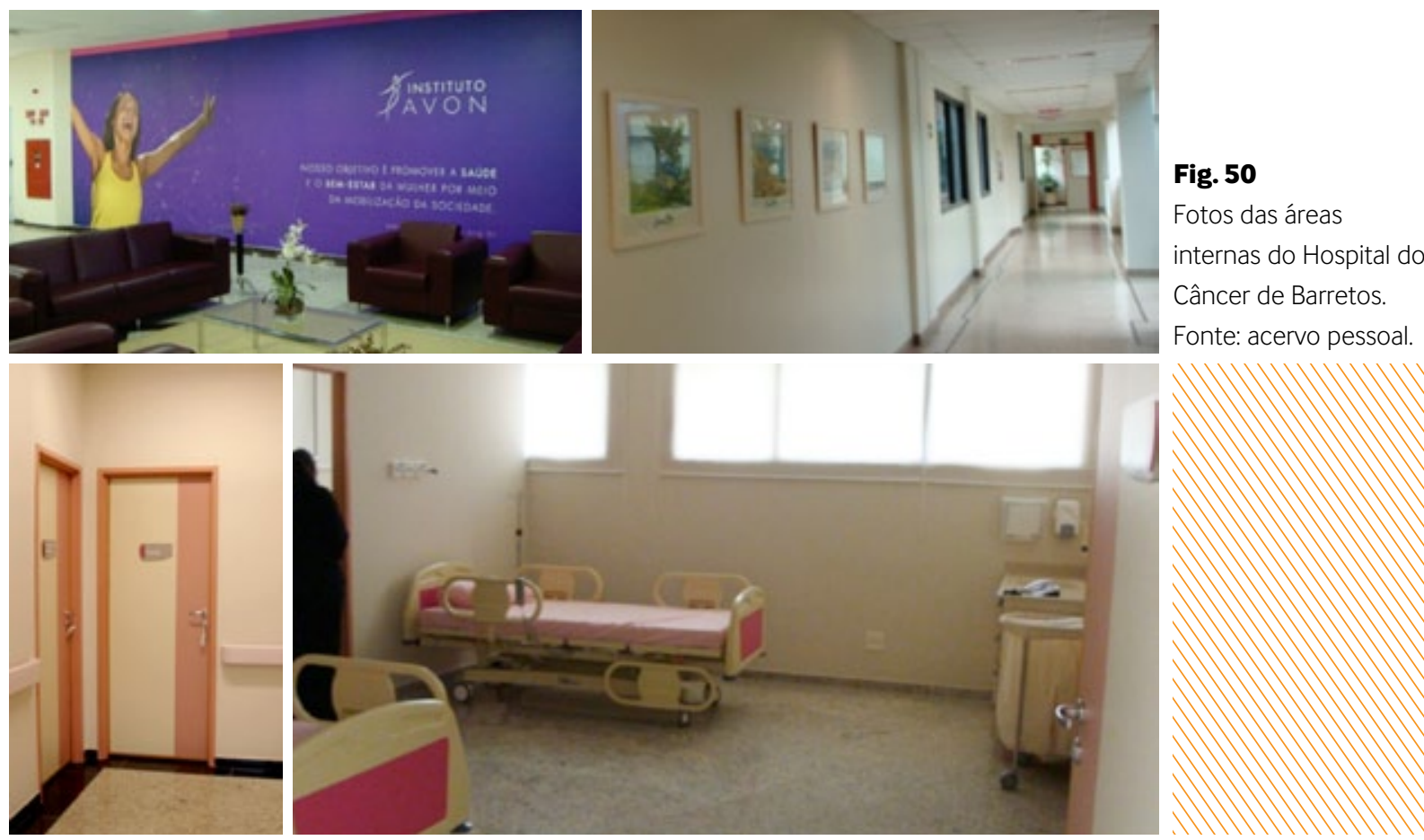

A Santa Casa de Porto Alegre muito se assemelha ao Hospital do Câncer de Barretos neste requisito, ou seja, tem a mesma postura em relação à ventilação natural condicionando artificialmente praticamente todos os ambientes fechados; tem a mesma eficiência com relação à iluminação natural e artificial; e a mesma forma de encarar a questão da utilização de cores.

Fato curioso: o Hospital Santa Clara, o mais antigo do complexo, está passando por processo de reforma e adequação de suas instalações de maneira a torná-las mais atuais. Dentre as várias aspirações para as enfermarias, está a climatização, ou seja, o condicionamento artificial de ar é uma busca efetiva da administração, muito provavelmente para se suprir uma falha da arquitetura que não conseguiu de maneira eficiente equacionar tal problema. A seguir, algumas fotos que ilustram a situação. 

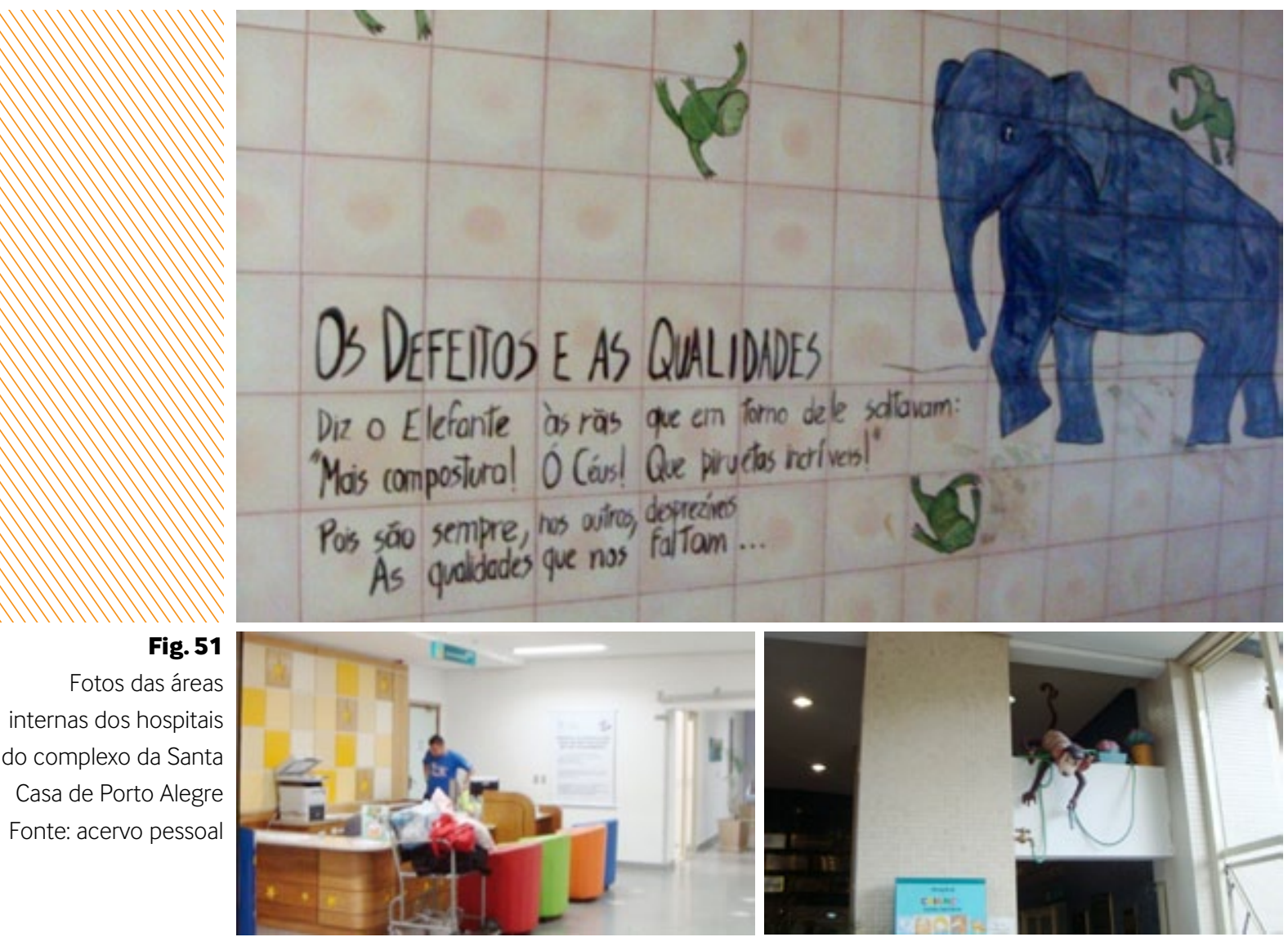

Na Santa Casa Dona Carolina Malheiros, de São João da Boa Vista, tanto a ventilação quanto a iluminação natural e artificial eram até algum tempo atrás muito bem utilizadas, em função da condição de qualidade oferecida e em função de sua tipologia. Além disso, a Santa Casa fica em um dos pontos mais altos da cidade, ou seja, ela tem abundância de ventilação natural e o fato de não ter em seu entorno, ainda que mais afastado, qualquer edifício alto que interfira em sua insolação. Assim, o condicionamento de ar vinha sendo utilizado, pelo menos até então, como complementação à ventilação natural, onde especificamente se exige controle maior de temperatura como UTIs, centros cirúrgicos, etc. e a iluminação artificial assumia mesmo papel, o de complementar a iluminação natural.

Até pouco tempo, os mecanismos de controle de insolação eram aquelas antigas venezianas de madeira, muito simples, porém muito eficientes. Atualmente estas venezianas estão sendo trocadas por venezianas de alumínio, já com controle de insolação não tão agradável.
Fato já apresentado e que está, pelo menos em parte, comprometendo o conforto ambiental nos ambientes da Santa Casa é a utilização dos espaços vazios sem critério algum. Tal fato prejudica a tão saudável ventilação e a iluminação natural que existia. De fato, agora algumas enfermarias efetivamente precisam de controle artificial de ventilação e iluminação, pois o fato de as janelas terem que ficar fechadas praticamente o tempo todo em função da falta de atrativos para se mantê-las abertas ou mesmo pelo fato de o reflexo das telhas metálicas das construcõos anexas apresentarem sério desconforto, principalmente visual.

Importante salientar como tal fato influencia praticamente todos os requisitos que se busca atender.

A seguir, foto que ilustra a situação favorável do entorno da Santa Casa.

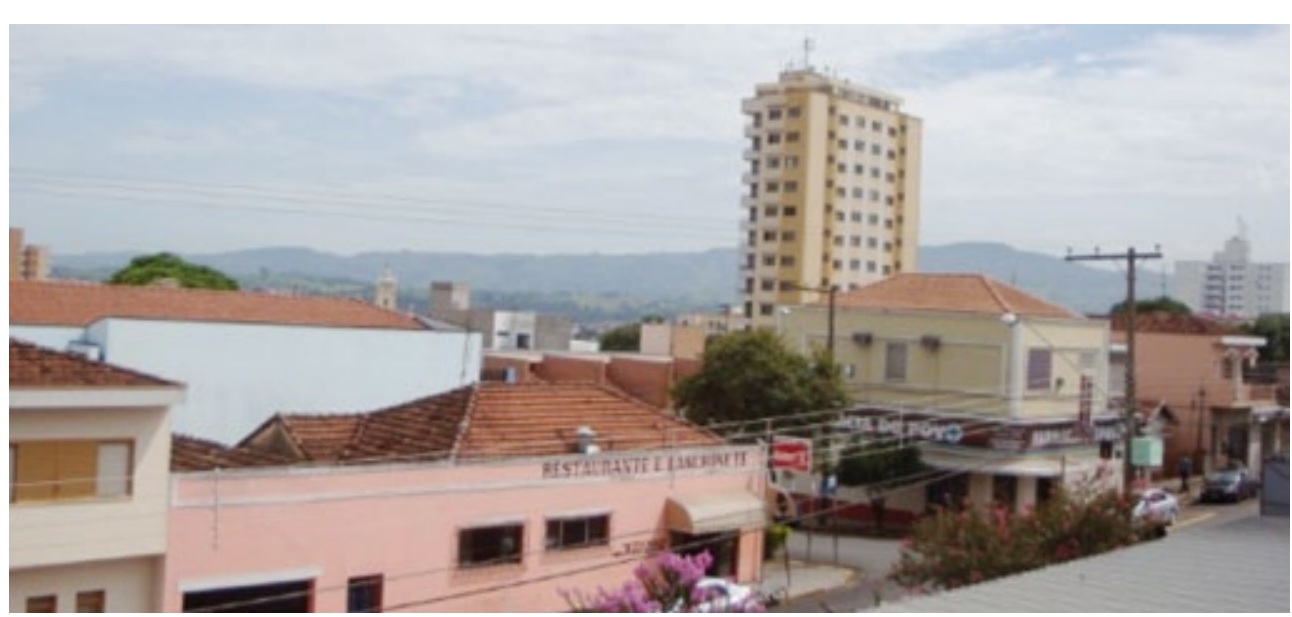

Foto da vista externa a partir das enfermarias SUS da Santa Casa Don Carolina Malheiros.

Fonte: acervo pessoal.

A seguir, foto que ilustra o corredor da ala das enfermarias destinadas aos convênios (ala executiva), totalmente desprovida de iluminação e ventilação natural.

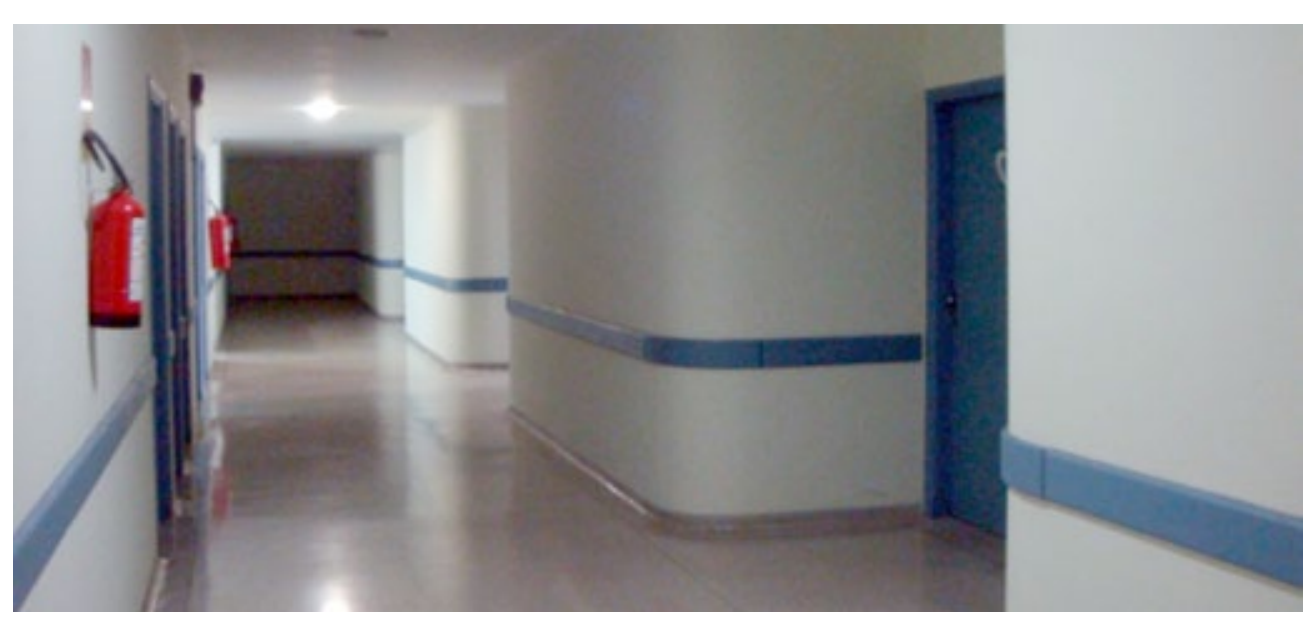

Fig. 53

Foto da circulação

interna da Santa

Casa Dona Carolina

Malheiros.

Fonte: acervo

pessoal. 
Com relação à utilização de cores, a Santa Casa teve caminho inverso, ou seja, atualmente se utiliza delas para buscar melhorar os ambientes internos, como já foi mostrado; as enfermarias do SUS masculinas utilizam uma cor, as femininas utilizam outra. Também há a utilização de cores nos espaços de espera, circulação, recepção, etc. Até há poucos anos, isso não acontecia. A cor predominante era o bege e o marrom, cores que intuitivamente remetiam à falta de salubridade. Enfim, neste aspecto, a Santa Casa apresenta-se eficiente.

A seguir, algumas fotos que ilustram a situação

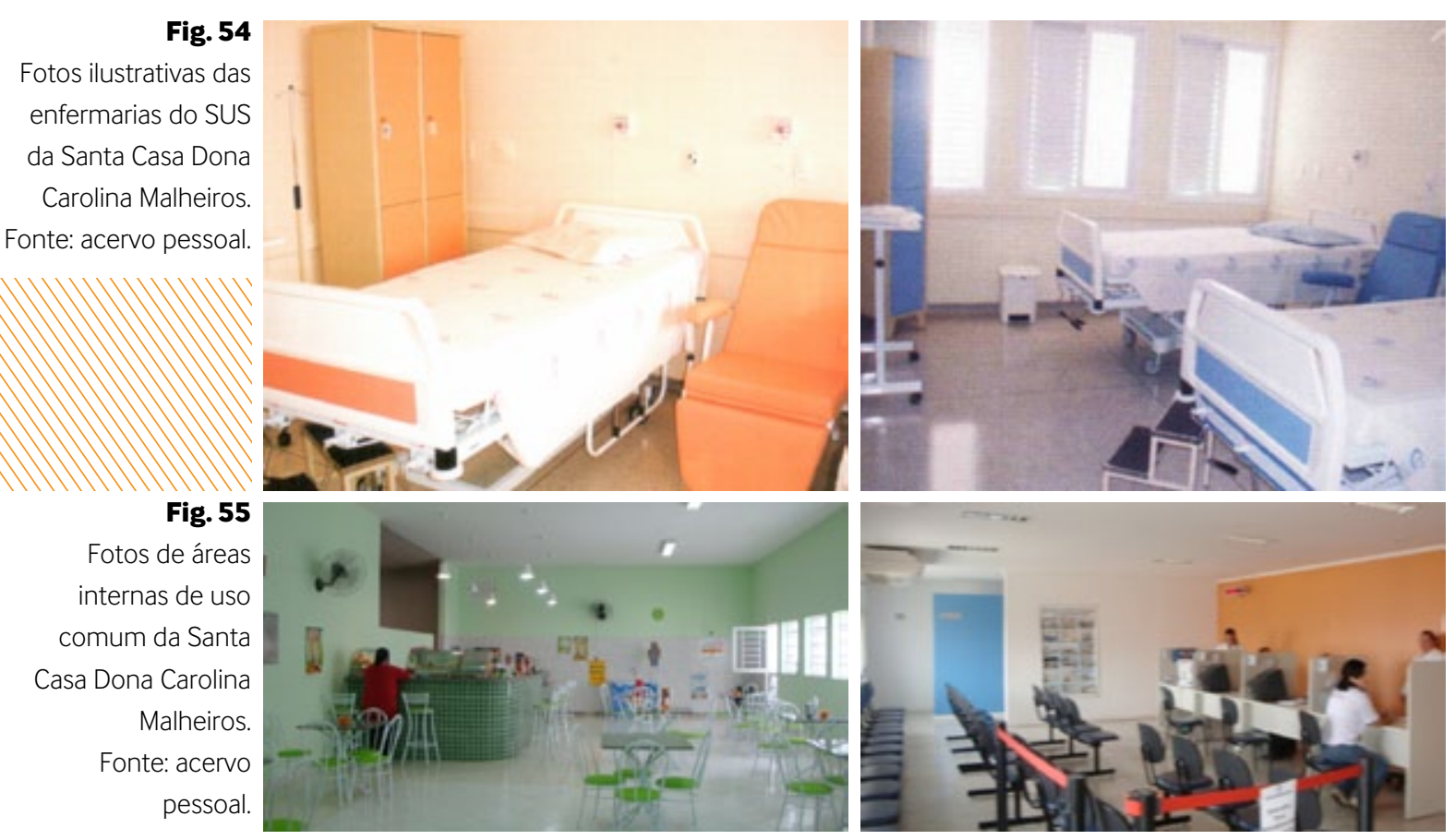

Este requisito, teoricamente é um dos que mais influência exerce sobre as pessoas frequentam os estabelecimentos. O uso correto das técnicas e das tecnologias permite resultados muito satisfatórios e benéficos para todos os usuários, em especial o utente. Porém, quando se fala em conforto térmico especificamente, a obtenção de seu resultado na maioria dos casos está longe de ser atingida. Tal situação não exatamente se dá pelo fato da falta de conhecimento técnico de seus projetistas mas principalmente pelo fato de as tecnologias existentes atualmente como condicionamento artificial de ar, controle de iluminação e insolação através de peles de vidro ou esquadrias de alto desempenho - facilitarem a obtenção dos resultados através de sua utilização. É uma maneira atualmente muito utilizada e que na verdade vem compensar situações que a arquitetura não foi capaz de resolver ou simplesmente não se preocupou em resolver por saber que há estes mecanismos disponíveis.

\subsubsection{Presença de verde}

A utilização de vegetação nas áreas dos Estabelecimentos Assistenciais de Saúde, conforme coloca a abordagem teórica, pode trazer benefícios tanto para o utente quanto para os funcionários e as equipes médicas. Tal artifício ajuda ainda a melhor resolver as questões de conforto térmico.

Outro artifício que pode ser utilizado em conjunto com a ventilação e trás ganhos na regulação do conforto térmico, conforto acústico, visual e olfativo além de oferecer a sensação de aconchego, é a utilização da água.

O Hospital Escola Municipal de São Carlos trás todos estes elementos em sua construção. O paisagismo, pelo menos na área concluída até agora, embora seja externo aos ambientes, parece estar dentro deles. O espelho de água, utilizado somente neste caso entre os estabelecimentos estudados, é outro artifício presente. Assim como a implantação total não está concluída, o paisagismo parece também não estar, mas certamente trará excelentes benefícios aos ambientes com os quais estabelecer diálogo.

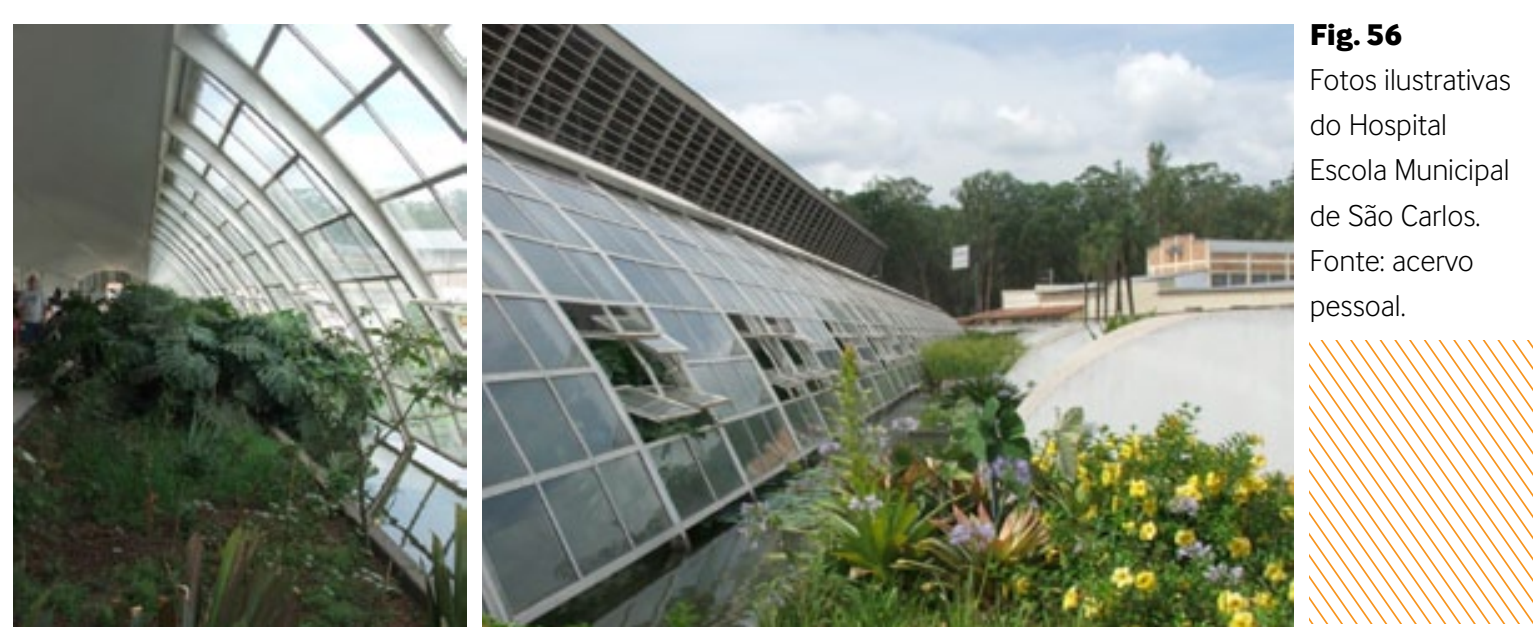

O Hospital do Câncer de Barretos também tem neste requisito, forte apelo. Utiliza-se de sua implantação para explorar ao máximo a utilização do paisagismo e, sem dúvida, é um dos elementos que mais agrega qualidade ao ambiente, juntamente com os demais requisitos. 
A seguir, algumas fotos ilustrativas.
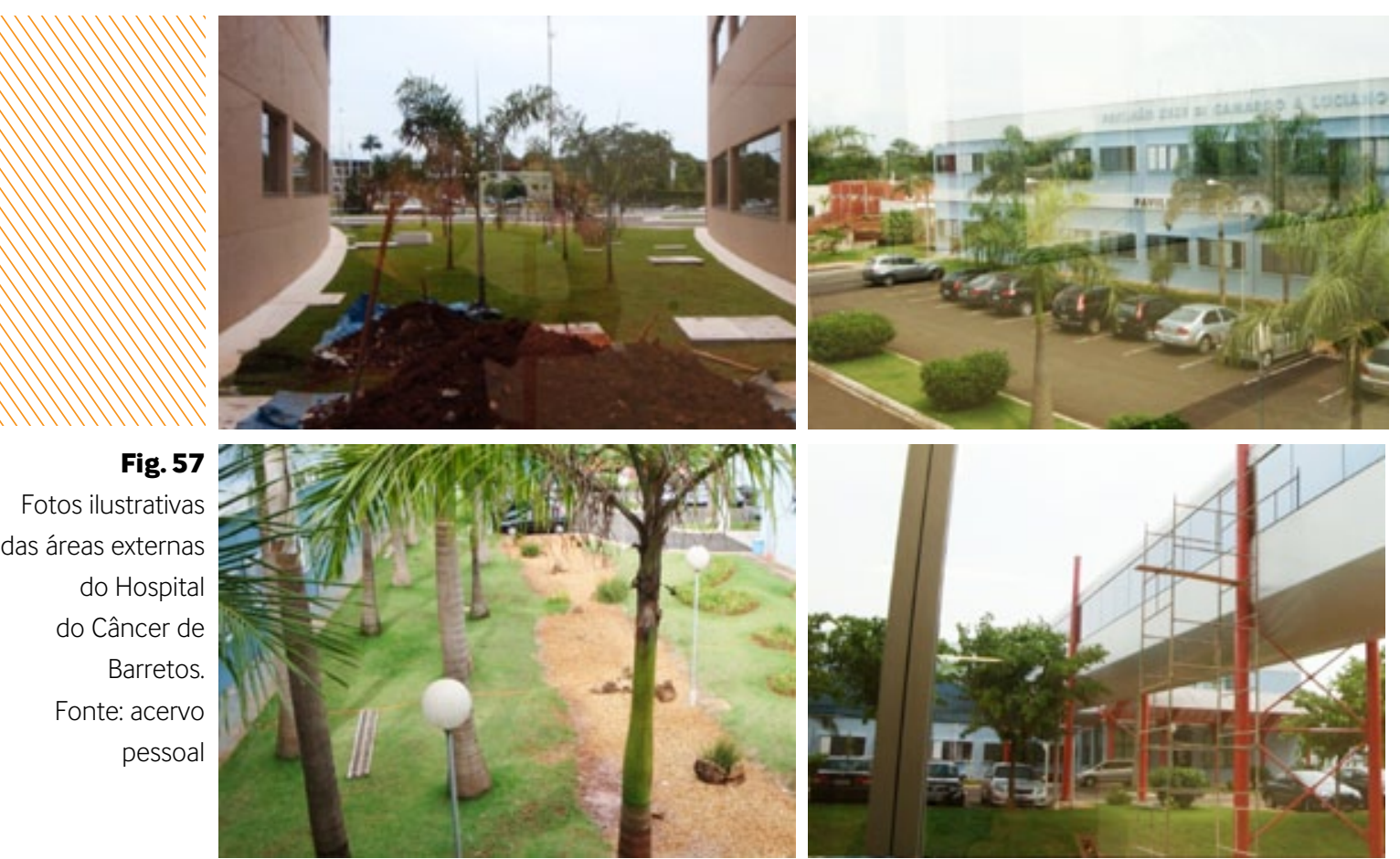

A Santa Casa de Porto Alegre tem também na utilização de paisagismo um de seus diferenciais. A Santa Casa é toda desenvolvida ao redor de praças, os estacionamentos são arborizados, enfim, por onde se ande, tem-se contato com o paisagismo. Excetuam dessa condição as construções mais atuais, onde o paisagismo ainda está em formação.

Fato estranho e até certo ponto ruim é que as enfermarias em si praticamente não têm contato com o paisagismo. Obviamente ele exerce grande e boa influência sobre os ambientes, mas, os ambientes mais necessitados de tal contato, por ter em seu interior os utentes que passam às vezes longos períodos internados, com esse contato não podem contar.

A utilização de água é muito pontual e pouco eficiente no conjunto todo. Existe através de pequenas fontes ou cascatas no interior dos jardins e praticamente passam despercebidas.
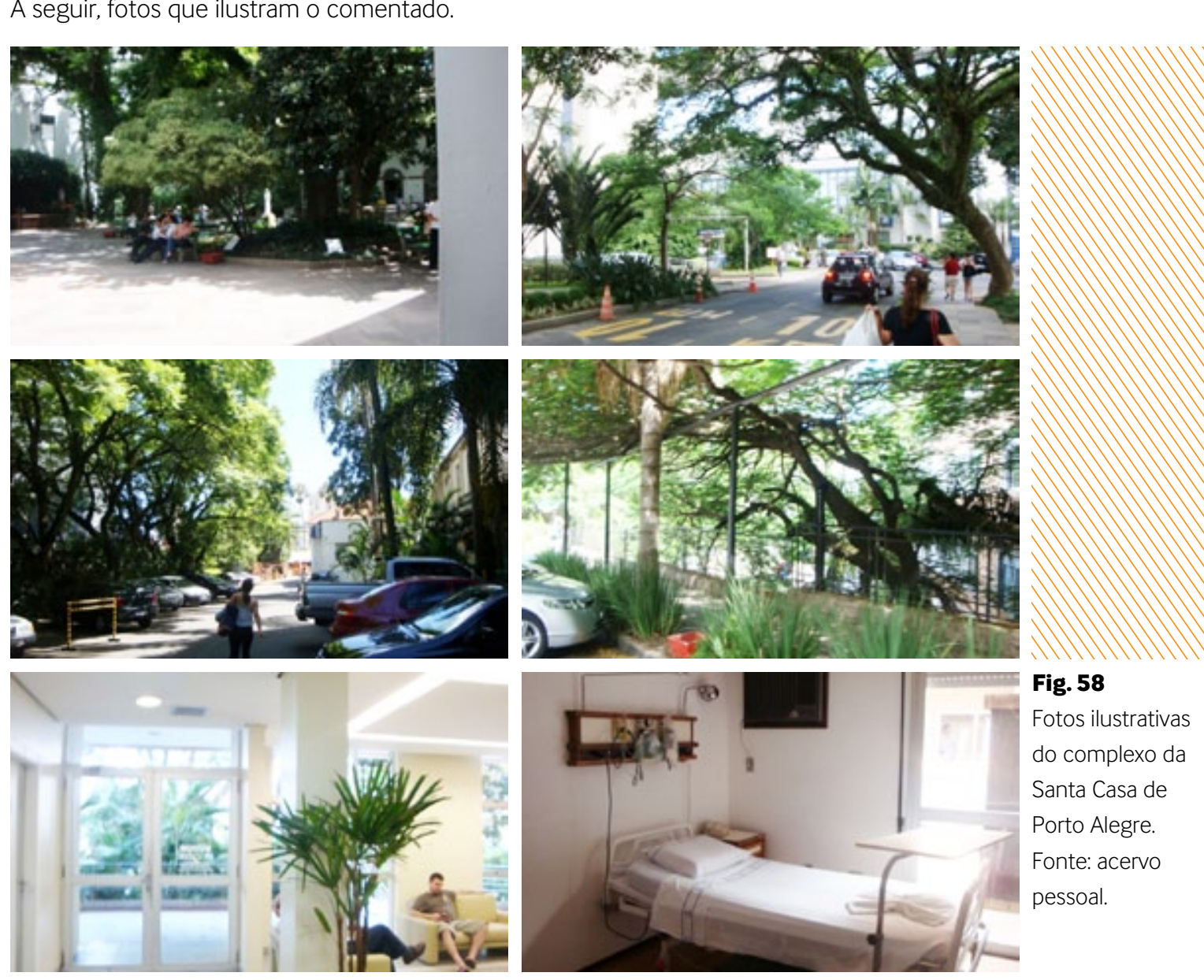

Na Santa Casa de São João da Boa Vista, Dona Carolina Malheiros, a presença de paisagismo somente pode ser constatada no jardim frontal da instituição que na verdade, de ambiente algum pode ser visto. Algumas enfermarias do pavilhão frontal têm algum contato com o paisagismo através de dois elementos independentes da Santa Casa: as árvores da calçada e a serra da Mantiqueira. Esta segunda torna mais agradável a permanência dos utentes em algumas enfermarias. 


\subsubsection{Relação interior $x$ exterior}

A questão da relação entre interior e exterior busca um diálogo entre as áreas internas e externas de um edifício, através das aberturas. Também esta relação está intimamente ligada à presença de verde.

Quando se fala em ligação entre interior e exterior, não necessariamente se fala em ligação física, mas ao menos uma ligação visual que ofereça uma composição de claros e escuros, transparências e opacidades, de cheios e vazios. Busca-se tornar a área externa uma continuidade da área interna. Se isso acontecer a relação será considerada muito eficiente.

Tal requisito traz muito conforto aos usuários, em especial ao utente, pois proporciona a ele a sensação de segurança, adquirida com a percepção de dia e noite e, em particular trás muito conforto aos utentes de longa estadia em um hospital, pois estes anseiam pelo prazer da luz natural e da visão do céu.

Analisando as instituiç̃es estudadas, pode-se concluir que de maneira eficiente, onde o ambiente externo se transforma na continuidade do interno, nenhuma das instituições consegue. O Hospital Escola Municipal de São Carlos é o que melhor aborda tal requisito, porém, sua abordagem se restringe ao grande saguão de entrada/espera e não contempla, por exemplo, os ambulatórios. De qualquer forma tem sua eficiência.

Os hospitais de Barretos e a Santa Casa de Porto Alegre, da mesma forma que acontece com o hospital de São Carlos, oferecem tal benefício parcialmente, pois só em algumas áreas é estabelecida boa relação entre o ambiente interno e o externo. Mas isso não ocorre com as áreas principais, como as enfermarias. Nas áreas que existe traz benefícios aos usuários, permitindo que eles identifiquem as condições de dia e noite e até as condiç̃oses do clima, o que Ihes confere bastante segurança. Todavia, desperdiçam a possibilidade de melhorar o ganho dos utentes por meio de um contato maior com a natureza.

A seguir, algumas fotos da Santa Casa de Porto Alegre, que ilustram como a relação entre o interior e o exterior existe em áreas comuns.
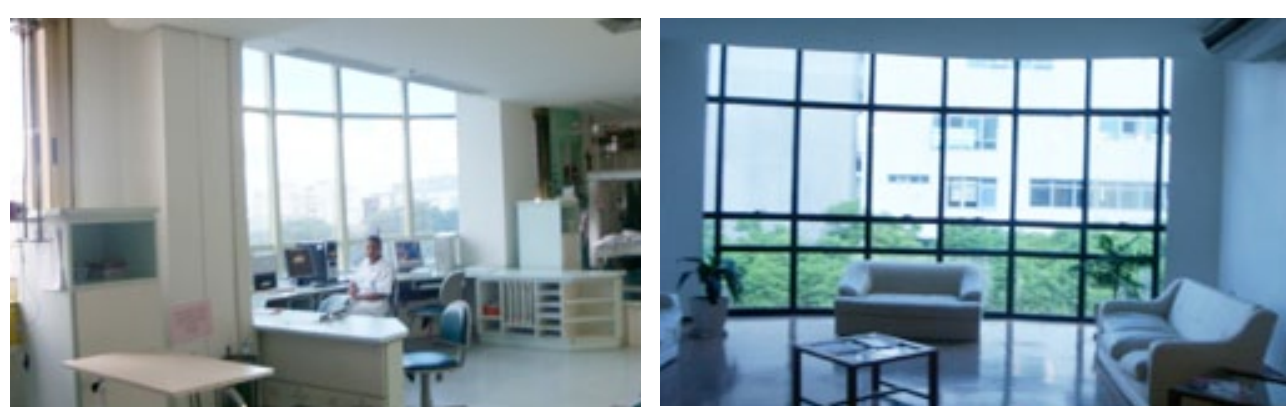

Na Santa Casa de São João da Boa Vista, Dona Carolina Malheiros, como se pôde notar, falta paisagismo. Os benefícios da relação entre os meios interior e exterior ocorrem de maneira parcial. Algumas enfermarias têm uma bela vista para a serra da Mantiqueira que oferece uma paisagem muito agradável aos utentes. Assim, essa relação é eficiente nesses casos em que ela existe, pois como na Santa Casa de Porto Alegre, cria no utente a sensação de dia e noite trazendo-Ihe assim segurança; ou mesmo permitindo a percepcão das condicões climáticas. Todos estes elementos oferecem alguma qualidade aos ambientes e consequentemente aos usuários, mas da mesma forma desperdiçam uma possibilidade de melhor eficiência, o que poderia trazer mais qualidade a todos os usuários.

Os dois requisitos (presença de verde e relação interior $x$ exterior) estão intimamente relacionados. Na teoria, a relação existente entre o ambiente interno com o externo pode trazer grandes benefícios aos ambientes como um todo e consequentemente aos seus usuários em especial os utentes. Esta relação traz uma série de vantagens a eles, como segurança, conforto etc., porém, se somada à presença de paisagismo, ela tem sua eficiência potencializada. $\mathrm{Na}$ prática, o que se vê em geral é sim uma preocupação com a presença de paisagismo, porém este ainda ocupa os lugares vazios que não são preenchidos com edificações. Ou seja, não se projeta, na maioria dos casos, visando sua relação com os espaços internos. Quando acontece, acontece despropositadamente. E a preocupação com a relação entre ambientes interiores e exteriores na prática acontece muito naturalmente inclusive sem planejamento. Poderia ser muito mais eficiente e desta forma impor muito mais qualidade aos ambientes. 


\subsubsection{Humanização dos espaços}

Por humanização pode-se entender um conjunto de atitudes que visam melhorar a qualidade do ambiente como um todo e, desta maneira, fazer com que ele contribua de maneira benéfica para qualidade de vida dos seus usuários. No caso do ambiente hospitalar, em relação ao utente, que melhore sua condições de estada e recuperação, em relação à equipe técnica, que melhore suas condições de trabalho.

A arquitetura é um dos fatores que torna os ambientes mais humanizados e, se os requisitos colocados até então forem atendidos, a arquitetura estará dando sua contribuição à humanização dos ambientes. Quanto maior o número de requisitos atendidos, maior será a contribuição da arquitetura.

A humanização é um fator, às vezes, considerado um diferencial, quando, na verdade, deveria significar sempre qualidade e como tal deveria ser um fator essencia.

O Hospital Escola Municipal de São Carlos, talvez seja o único dos estabelecimentos analisados em que ainda não se possam tirar conclusões satisfatórias, uma vez que seu atendimento ao utente atualmente não ser completo ainda. De qualquer forma, a etapa concluída atende de maneira satisfatória a vários requisitos: sua adequaç̃ão ao local é eficiente; o fato de o projeto resultar de um estudo funcional e técnico do problema provavelmente aconteceu, o que, na prática, ainda não se pode apurar; a racionalização das circulações e o agrupamento de usos e atividades afins desde já se mostram eficientes; o auxilio na prevenção à infeccão hospitalar proporcionado pela contribuição da arquitetura também é eficiente desde esta etapa; a flexibilidade dos ambientes é total; a preocupação com o conforto ambiental como um todo também é muito evidente; a presença de verde é realidade, pelo menos na etapa implantada; e a relação entre interior e exterior em alguns ambientes é eficiente, mas é outro requisito que não pode ser analisado conclusivamente em função de seu estágio de implantação.

Desta forma, no caso deste hospital, pode-se concluir que existe sim humanização dos espaços e a parte da humanização que é de responsabilidade da arquitetura está bastante evidente: a arquitetura muito contribui para a humanização deste estabelecimento.

No Hospital do Câncer de Barretos, pode-se dizer, tem ambientes humanizados. Com relação à arquitetura e os requisitos básicos colocados temos: na adequação ao local, uma situação bastante eficiente; no requisito que fala que o projeto deve resultar de um estudo funcional e técnico do problema, também foi constatada eficiência; na racionalização das circulações e agrupamento de usos e atividades afins, a instituição também é bastante eficiente: na prevenção à infecção hospitalar, naquilo que a arquitetura pode contribuir, contribui de maneira eficiente; com relação à flexibilidade dos ambientes, atende parcialmente, pois as construç̃oes mais antigas oferecem certa dificuldade neste aspecto, embora de forma não comprometedora; a preocupação com o conforto ambiental existe, porém no caso específico da ventilação natural não tem eficiência total; a presença do verde é uma realidade e a relação entre interior e exterior acontece de maneira satisfatória, pois nas enfermarias, em especial, tal requisito pode ser considerado limitado por falta de paisagismo.

Desta forma, pode-se concluir que o Hospital do Câncer de Barretos tem alto grau de humanização e, naquilo que a arquitetura contribui para isso, sua participação pode ser dita eficiente.

Na Santa Casa de Porto Alegre, pode-se dizer que a busca pela humanização também é uma realidade. Com relação aos requisitos básicos colocados temos: na questão na adequação ao local, uma situação de difícil análise pela idade da instituição, mas não se pode dizer que não atende, tanto que nos últimos anos a instituição passou por diversas ampliações de maneira bastante eficiente; o fato de o projeto resultar de um estudo funcional e técnico do problema é outro requisito atendido, principalmente quando se analisa os hospitais do complexo um a um; a racionalização das circulações e agrupamento de usos e atividades afins, podem ser vistos de formas diferentes nos hospitais mais antigos e nos mais atuais, porém de forma geral o requisito pode ser considerado atendido com eficiência; consequentemente no auxilio a prevenção da infecção hospitalar, naquilo que a arquitetura tem condiç̃oes de contribuir, de fato contribui; na questão da flexibilidade dos ambientes, esta também pode ser vista de diferentes formas nos antigos e atuais hospitais: nos antigos acontece em grau menor que nos atuais, embora isso não chegue a comprometer a adequação dos ambientes às novas técnicas e tecnologias da medicina atual, tanto que todos os hospitais funcionam ainda hoje, há mais de 200 anos com a mesma finalidade; no requisito preocupação com o conforto ambiental, pode-se dizer que ele é parcialmente atendido pois no quesito ventilação natural, esta é colocada de lado em detrimento ao uso do condicionamento artificial, muito em função inclusive do fato de as novas instalações seguirem o padrão arquitetônico denominado monobloco vertical; a presença de verde é uma constante exceto em um dos locais mais importantes - as enfermarias -, ou seja, neste requisito a instituição chega a ter um comprometimento; e na relação entre interior e exterior, há eficiência porém limitada exatamente pela falta da presença de verde nas enfermarias.

A Santa Casa Dona Carolina Malheiros de São João da Boa Vista, dentre as instituições analisadas, pelo menos naquilo em que a arquitetura pode contribuir, é a que menos pode ser considerada humanizad 
Com relação aos requisitos mínimos temos: na adequação ao local, eficiência comprovada, pois apesar da idade da instituição, sua adequação ainda pode ser considerada satisfatória; com relação ao projeto resultar de um estudo funcional e técnico do problema, analisou-se que a Santa Casa em sua forma original atende tal requisito com bastante eficiência, porém com o processo de revitalização pelo qual está passando, esse requisito fica comprometido; o mesmo acontece com a questão da racionalização das circulações e agrupamentos de usos e atividades afins, ou seja, o que era considerado eficiente começa a se perder com o processo de atualização pelo qual está passando no momento; desta forma, naquilo que a arquitetura pode contribuir para a humanização, está deixando de ser racional, inclusive pouco podendo contribuir na prevenção à infecção hospitalar; com relação à flexibilidade dos ambientes, analisando-se a instituição em dois momentos pode-se dizer que as instalações antigas não poderiam ser consideradas tão flexíveis porém também não chegavam a comprometer sua adequação futura e, nas instalações atuais tal preocupação já se faz bastante presente; a preocupação com o conforto ambiental pode ser considerado de certa forma comprometido pelas atuais intervenções, o que pode inclusive se agravar com as futuras adequaç̃es; a presença de verde é praticamente inexistente e quando existe não é por iniciativa da instituição; e a relação entre o interior e o exterior existe mas, pelo fato de não haver a presença de paisagismo, chega a ficar comprometida.

Como se vê, a Santa Casa de São João da Boa Vista é a que menos atende aos requisitos analisados. Ainda apresenta uma situação a ser considerada que é o entendimento da humanização como um diferencial comercial e não como qualidade. Se percebe-se esse entendimento na iniciativa de incrementar as enfermarias destinadas ao atendimento particular ou conveniado com aparatos tecnológicos, julgando que isso torna tais ambientes melhores. Desta forma, seguramente a instituição pode ser considerada a menos humanizada entre as estudadas.

Com as análises individuais explicitadas, algumas considerações gerais precisam ser colocadas.

De maneira geral, ao se comparar a teoria com a prática, pode-se concluir que em grande parte dos casos aquilo que a teoria postula, efetivamente se verifica na prática. Quando não acontece, isto se dá muito mais por falta de parametrização do que por falta de recursos exatamente. De maneira geral, os requisitos - parâmetros levantados na teoria - inclusive por não serem objetivo de meta ou legislação, não podem ser considerados na grande maioria dos casos, como objetivos a serem atingidos. Na prática, o que acontece é que os ambientes se tornam mais humanizados pela consequência de seus usos. Usos esses muito mais empíricos ou despretenciosos do que necessariamente objetivados. Ou seja, se na grande maioria dos requisitos listados eles, ou parte deles, acontece na prática, isso se dá de forma natural e não exatamente projetada. Tal postura precisa mudar pois, quando isso acontece, como temos no exemplo do Hospital Escola de São Carlos como referência disso, os resultados podem ser potencialmente elevados.
Visando colocar de maneira didática, de forma bastante sistemática e objetiva, a tabela abaixo visa resumir e explicitar de forma geral aquilo que foi constatado quando da análise dos hospitais, não de forma comparativa mas sim afim de se estabelecer um panorama geral de toda a análise.

\begin{tabular}{|c|c|c|c|c|}
\hline FATOR ANALISADO & 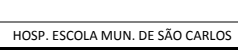 & 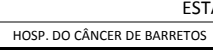 & $\begin{array}{l}\text { ENTOS } \\
\text { SANA CASA DE PORTO OALGRE }\end{array}$ & 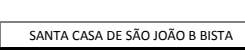 \\
\hline 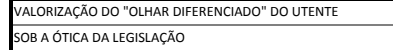 & VALOREA & 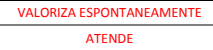 & 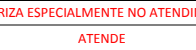 & 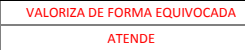 \\
\hline 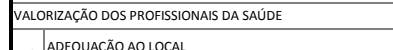 & 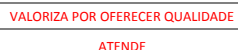 & 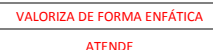 & 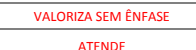 & 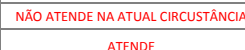 \\
\hline 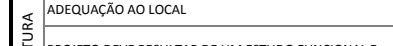 & AENDE & ATENDE & ATENDE & $\begin{array}{l}\text { ATENDE } \\
\text { ATENOE POREM PASA PO }\end{array}$ \\
\hline 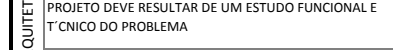 & ATENDE & ATENDE & ATENOE & 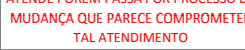 \\
\hline 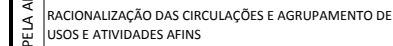 & ATENDE DE FORMA EFGLENTE & ATENDE DE F FRMA EFGCENTE & ATENOE & 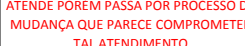 \\
\hline 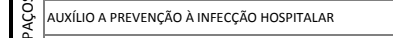 & ATENOE & ATENDE SATSEATTORAMNENE & AtENDE SATSSATORAMMENTE & 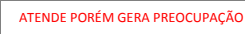 \\
\hline 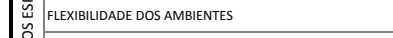 & ATENDE & ATENDE COM RESTRLLC̆̋SE & AEENDE COM RESTRCOCOSS & ATENDE COM RESTRAGGOES \\
\hline 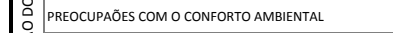 & ATENOE ExEMPLARNENE & ATENOE PACCAMMENTE & ATENDE PACCAMUENTE & 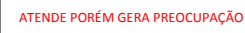 \\
\hline 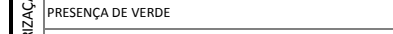 & ATENDE & ATENDE EAACAMMENETE & AEENDE PACCAMMENTE & NÄOATENOE \\
\hline 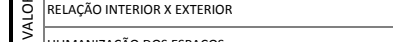 & ATENDE & ATENE AARCAM & ATENDE PARCIALMENTE & NÄOATENOE \\
\hline HUMANIZAGGÁD Dos EsPAGGS & & ATENOE & ARENOE & \\
\hline
\end{tabular}

Também se nota que, nos casos dos hospitais especializados, a humanização parece ser, se não mais eficiente, mais natural. Talvez pelo fato de se entender na prática, a existência de um requisito que a teoria não abordou: conhecer o usuário, em especial o utente e seus acompanhantes. Quando isso acontece, e a prática mostra isso, os resultados são mais visíveis, se não mais eficientes. Isso acontece no caso dos hospitais especializados, muito provavelmente sem intenção. O fato é que, quando se constrói algo mais focado em um determinado perfil de usuário, e isso acontece obviamente nesses casos, o resultado obtido certamente é melhor Depois de se analisar toda a situação na teoria e na prática, certamente este requisito passará a fazer parte dos requisitos básicos pois, aquilo que acontece naturalmente em alguns casos, se levado a fundo nos casos em geral, muito pode contribuir para se atingir a humanização.

A hipótese deste trabalho coloca que, nos hospitais que atendem o público do SUS, o fato de não haver nestes estabelecimentos condições de se investir em decoração, equipamentos diferenciados, hotelaria, luxo, etc. faz com que eles busquem nos elementos essenciais da arquitetura - os requisitos básicos - sua garantia de eficiência no tocante à humanização dos ambientes. Tal fato na realidade acontece. Nestes estabelecimentos, mesmo sem haver a presença dos artifícios de luxo e hotelaria, através da presença dos requisitos arquitetônicos básicos que promovem a mínima e necessária qualidade dos ambientes, pode-se efetivamente se considerar que tais estabelecimentos têm ambientes realmente humanizados. Mais ainda, nos exemplos práticos analisados, há o caso de estabelecimento que utiliza-se desses artifícios acessórios de luxo para buscar humanizar seus ambientes e vemos que, de fato, não o conseguem. Os requisitos estão ligados à essência da qualidade ambiental e, sem ela, muito pouco se pode compensar com os acessórios no que diz respeito à humanização. 
Capítulo 6

Conclusão 
O propósito geral que motivou esta dissertação foi o de buscar entender se a preocupação com a questão da humanização dos ambientes está realmente presente nos hospitais voltados ao atendimento público e, em ela existindo, compreender qual o papel que a arquitetura poderia ter ou desenvolver, através de uma combinação de requisitos denominados de básicos, na humanização desses ambientes de saúde.

Tomando-se como referência o estudo - e mesmo a vivência pessoal - em quatro hospitais de atendimento ao público do país, em diferentes portes e complexidades operacionais, pôde-se concluir que a preocupação com a humanização em seus ambientes efetivamente existe e é de fato condição premente nas suas operações. Em todos os hospitais analisados a preocupação com a questão da humanização está presente, mesmo que em diferentes graus e maneiras. A influência que ela exerce nos ambientes é perceptível, trazendo aos usuários muitos benefícios. Assim, dá aos utentes, melhores condições de recuperação, aos trabalhadores melhores condições de desenvolver suas atividades com segurança, eficiência, conforto e consequentemente, com maior prazer, bem como aos acompanhantes sensação de bem-estar, conforto e segurança. Em o ambiente exercendo boa influência sobre os usuários, maiores benefícios ainda serão possibilitados à recuperação do utente: os profissionais, por trabalharem com prazer, segurança, melhor assistirão os utentes; os acompanhantes, que têm fundamental participação na recuperação do utente, quando têm a sensação de conforto, segurança e bemestar, para os utentes passarão tais sentimentos.

Assim, de fato e como esperado a humanização dos ambientes é eficiente e tem condiç̃̃es de oferecer vantagens adicionais aos usuários dos sistemas públicos de saúde.

Fato que precisa ser evidenciado, no entanto, é que a humanização existente em tais 
estabelecimentos acontece de maneiras diversas e a arquitetura, através do adequado planejamento e implantação dos requisitos básicos e necessários para um pensamento arquitetônico voltado para a questão, pode influir e mesmo possibilitar a qualidade e a intensidade em que a humanização se apresenta, se internaliza e opera nos hospitais.

Nossa hipótese de trabalho de que a arquitetura, através dos requisitos básicos elencados, daria conta de promover um grau mínino e suficiente de humanização nos hospitais públicos desprovidos de recursos de hotelaria e de luxo se confirma, já que os estabelecimentos analisados têm maior ou menor grau de humanização relacionados diretamente ao fato de atenderem aos requisitos arquitetônicos básicos. Ficou evidente, na teoria e na prática, que quanto mais adequadamente os requisitos foram atendidos, mais humanos se tornaram os ambientes. Tal fato explicita que realmente o que impõe humanização aos ambientes é a qualidade desses ambientes - e esta qualidade só pode ser motivada através do atendimento dos requisitos arquitetônicos básicos que voltam os olhares da arquitetura hospitalar em direção à humanização. Ou seja, os requisitos que possibilitam a essência da qualidade é que são os grandes responsáveis pela humanização dos ambientes, combatendo desta forma a vertente que acredita conseguir na utilização de subterfúgios comerciais - decoração, hotelaria, luxos, etc. - a humanização dos ambientes. A prática nos mostrara que efetivamente tais elementos devem ser considerados acessórios.

Uma colocação, no entanto, não se pode deixar de fazer: há uma diferença de enfoque muito clara da arquitetura quanto ao atendimento aos requisitos básicos dentre todos os hospitais analisados. Se no Hospital Escola Municipal de São Carlos o atendimento aos requisitos arquitetônicos básicos é um objetivo, principalmente um objetivo já de projeto, nos demais estabelecimentos tais requisitos se apresentam como uma consequencia e como uma necessidade. Pode-se até inferir que o conceito de humanização dos espaços, na prática, ainda não esteja claro, mas o fato é que uma orientação e um viés mais voltado para a humanização já deve brotar nas linhas e nos traços iniciais do projeto hospitalar, deve estar presente no olhar do arquiteto. É só a partir dessa perspectiva que se pode pensar na otimização mesma de uma iniciativa arquitetônica efetivamente voltada para a humanização dos ambientes de saúde.

Não coincidentemente, dentre os estabelecimentos estudados, os mais humanizados são aqueles que também oferecem maior qualidade, no aspecto global e técnico, aos seus usuários. Ou seja parece haver, nesses hospitais, uma relação mais íntima entre a contribuição da arquitetura na humanização dos ambientes públicos de saúde e a qualidade do tratamento oferecido.

Nesses diálogos entre as teorias e as práticas hospitalares aqui realizados, espera-se que este trabalho forneça elementos que possam contribuir para o pensamento e para o planejamento de projetos arquitetônicos hospitalares mais eficientes no tocante à humanização e se, de fato, humanização e qualidade guardarem relação estreita, como os indicativos aqui levantados parecem evidenciar, projetos arquitetônicos de maior qualidade e completude, portanto. Partindo-se do princípio de que a legislação em vigor por si só não tem como garantir a qualidade da humanização dos ambientes, os elementos aqui apresentados servem como referencial e como um "percurso geral", espera-se, para a elaboração de novos projetos voltados à arquitetura hospitalar. Uma arquitetura mais voltada à humanização dos ambientes, espera-se, já que o espaço e o homem são, necessária e fundamentalmente, as principais referências e as fontes de toda arquitetura. 


\section{Referências}

\section{Bibliográficas}

AGÊNCIA NACIONAL DE VIGILÂNCIA SANITÁRIA - ANVISA. Resolução da Diretoria Colegiada RDC n.50. Disponível em <www.anvisa.org.br>. Acesso em: outubro de 2009.

ALMEIDA, Lula de. 0 desempenho exigido das tintas nos hospitais. Revista Periódico

Projeto Design. São Paulo: First Line,ed.206, p.13, 1997.

ANELLI, R:; GUERRA, A. \& KON, N. Rino Levi Arquitetura e Cidade. São Paulo: Romano Guerra Editora, 2001

\section{ARCOWEB. Ambiente hospitalar requer humanização e potencial de atualização} constante. Disponivel em: <http://www.arcoweb.com.br/debate/debate57.asp> Acesso em: 07 março 2007.

ARCOWEB. Arquitetura Hospitalar. Disponível em: <http://www.arcoweb.com.br/tecnologia/ tecnologia7.asp> Acesso em: 07 março 2007.

ARQUITETURA da Felicidade. Escrito e apresentado por Alain de Boton. Direção de Neil

Crombie. [SI]: Ed. Abril, s/d. DVD (138 min.), sonoro, colorido, digital. Legendado. Inglês/Português.

ASSUMPÇÃO, J. F. P.; FUGAZZA, A. C. Coordenação de projetos de edificios-Um sistema para programação e controle de fluxo de atividade do processo de projetos.In: workshop Nacional:Gestão do processo de projetos na construção de edifícios,2001,São Carlos anuais..... São Carlos, SP. 2001. p. 62-70.

AUSTIN, John Langshaw. Sentido e percepção. São Paulo: Martins Fontes, 1993.

BITTENCOURT, Tânia. Arquitetura Sanatorial. São José dos Campos: TMM Bittencourt, 1998. BRASIL, Conselho Nacional de Secretários de Saúde. Legislação do SUS / Conselho Nacional de Secretários de Saúde. Brasília: CONASS, 2003. 
BRASIL, Conselho Nacional de Secretários de Saúde. Legislação do SUS / Conselho Nacional de Secretários de Saúde. Brasília: CONASS. 2003.

BRASIL, Conselho Nacional de Secretários de Saúde. SUS 20 anos. / Conselho Nacional de Secretários de Saúde. - Brasília: CONASS, 2009.

BRASIL, Conselho Nacional de Secretários de Saúde. SUS: avanços e desafios. / Conselho Nacional de Secretários de Saúde. Brasilia: CONASS. 2006

BRASIL, Ministério da Saúde. A Política de Saúde no Brasil nos anos 90: avanços e limites / Ministério da Saúde; elaborado por Barjas Negri. Brasilia: Ministério da Saúde, 2002.

BRASIL, Ministério da Saúde. Secretaria de Assistência à Saúde. Série Saúde \& Tecnologia - Textos de Apoio à Programação Física dos Estabelecimentos Assistenciais de Saúde - Arquitetura na Prevenção de Infecção Hospitalar. Brasília, 1995.

BRASIL, Ministério da Saúde. Secretaria de Atenção à Saúde. Núcleo Técnico da Política Nacional de Humanização. Ambiência / Ministério da Saúde. Secretaria de Atenção à Saúde. Núcleo Técnico da Política Nacional de Humanização. - 2 ed. - Brasilia: Editora do Ministério da Saúde, 2009.

BRASIL, Ministério da Saúde. Secretaria de Atenção à Saúde. Núcleo Técnico da Política Nacional de Humanização. HumanizaSUS: Documento base para gestores e trabalhadores do SUS / Ministério da Saúde. Secretaria de Atenção à Saúde. Núcleo Técnico da Política Nacional de Humanização. - 4. ed. - Braślia: Editora do Ministério da Saúde, 2009.

BRASIL, Ministério da Saúde. Secretaria de Atenção à Saúde. Núcleo Técnico da Política Nacional de Humanização. HumanizaSUS: visita aberta e direito a acompanhante / Ministério da Saúde. Secretaria de Atenção à Saúde. Núcleo Técnico da Política Nacional de Humanização.- 2. ed. - Brasília: Ministério da Saúde, 2009.

BRASIL, Ministério da Saúde. Secretaria de Atenção à Saúde. Política Nacional de Humanização da Atenção e Gestão do SUS. O HumanizaSUS na atenção básica. / Ministério da Saúde. Secretaria de Atenção à Saúde. Política Nacional de Humanização da Atenção e Gestão do SUS. - Brasilia: Ministério da Saúde, 2009.
BRASIL, Ministério da Saúde. Secretaria-Executiva. Programa humanização do Parto humanização no pré-natal e nascimento / Ministério da Saúde. Secretaria-Executiva. Brasilia: Ministério da Saúde, 2002

BRASIL, Ministério da Saúde. Secretaria-Executiva. Subsecretaria de Assuntos Administrativos. SUS 20 anos - a saúde do Brasil. / Ministério da Saúde, Secretaria-Executiva, Subsecretaria de Assuntos Administrativos - Brasília: Editora do Ministério da Saúde, 2009

BRASIL, Ministério da Saúde. Secretaria-Executiva. Departamento de Apoio à Descentralização. o sUS no seu município: garantindo saúde para todos. /Ministério da Saúde,

Secretaria-Executiva, Departamento de Apoio à Descentralização - 2. Ed. - Brasilia: Ministério da Saúde, 2009

BRASIL. Ministério da Saúde. Secretaria-Executiva. Núcleo Técnico da Política Nacional de Humanização. HumanizaSUS: acolhimento com avaliação e classificação de risco: um paradigma ético-estético no fazer em saúde / Ministério da Saúde. Secretaria-

Executiva. Núcleo Técnico da Política Nacional de Humanização. - Brasilia: Ministério da Saúde 2004

BRASIL, Ministério da Saúde. Secretaria-Executiva. Núcleo Técnico da Política Nacional de Humanização. Prêmio HumanizaSUS David Capristano: Política Nacional de Humanização. - Brasília: Ministério da Saúde, 2004.

BRASIL, Ministério da Saúde. O SUS de A a Z: Garantindo Saúde nos Municípios Ministério da Saúde, Conselho Nacional das Secretarias Municipais de Saúde - 3. Ed. Brasília: Editora do Ministério da Saúde, 2009.

CAPMAN, Janet R.; GRANT, Myron A.; SIMMONS, Deborah A. Design that cares: planning health facilities for pacientes and visitors. Chicago: American Hospital Publishing 1986.

CARMO FILHO, José Coutinho do. Conforto Térmico em Estabelecimentos

Assistenciais de Saúde. Monografia (Especialização), Universidade Federal da Bahia, Salvador, 2007. 
CASTELLS, Eduardo ; HEINEK, Luis Fernando M. A aplicação dos conceitos de qualidade de projeto no processo de concepcão arquitetônica - uma revisão crítica.

Disponível em: http://www.arquitetura.uema.br/arquivos/material/marciamarques/texto_01. pdf Acesso em 11 novembro 2008

CAVALCANTI, Patrícia Biasi. Qualidade da lluminação em Ambientes de Internação Hospitalar. Dissertação (Mestrado) - Faculdade de Arquitetura e Urbanismo, Universidade Federal do Rio Grande do Sul, Porto Alegre, 2002.

CORBELLA, Oscar; YANNAS, Simons. Em busca de uma arquitetura sustentável para os trópicos: Conforto Ambiental. Rio de Janeiro: Revan, 2003

CORRÊA, Maria Luiza Trindade. Psicologia ambiental em um hospital infantil: uma análise comportamental de qualidade de vida e bem-estar. São Paulo, 2006.

Dissertação (Mestrado em psicologia clínica).Faculdade de Psicologia da Pontifícia Universidade de São Paulo.

COSTI, Marilice. A inflência da cor em corredores e salas de espera hospitalares. Porto Alegre : EDIPUCRS, 2002.

COSTI, Marilice. A Sala de morrer e a máquina de curar - a enfermaria fótica e o hospital renascentista. Monografia. Porto Alegre: Faculdade de Arquitetura, Programa de Pós-Graduação em Arquitetura. UFRGS, 1997.

DALLAS, Tereza Cristina Marques. Estudo da qualidade do ambiente hospitalar como contribuição na recuperação de pacientes. Natal, 2004. Dissertaç̃o (mestrado em engenharia civil) - Programa de pós-graduação em psicologia, Universidade Federal do Espírito Santo.

DALMASSO, Gabriela Liuzzi. A Relação entre Espaço e Saúde: Uma contribuição da Arquitetura para a Humanização da Unidade de Tratamento Intensivo. Dissertação (Mestrado) - Faculdade de Arquitetura e Urbanismo, Universidade Federal do Rio de Janeiro. Rio de Janeiro, 2005.

DEVLIN, A.S. \& ARNEILL, A. B. Health care environments and patient outcomes. A review of the literature. Journal of Environment and Behavior, 35, pp. 665-694.
FACULDADE DE ARQUITETURA - UFBA. ANAIS II seminário de Arquitetura Hospitalar. Salvador: Quarteto Editora, 2000

FIGUEIREDO, Vera M. de O. Arquitetura hospitalar. In: Infecção Hospitalar: epidemiologia e controle. Disponível em < http://www.bibliomed.com.br>. Acesso em outubro de 2001

FRANCO, Sérgio da Costa; STIGGER, Ivo. Santa Casa 200 anos:caridade e ciência. Porto Alegre: Ed. da ISCMPA, 2003

FROTA, Anésia Barros e SCHIFFER, Sueli Ramos. Manual do conforto térmico. São Paulo: Studio Nobel,2003.

GERROLA, Giovanny. Saúde in loco - A humanização do hospital, proclamada e transformada em realidade com os projetos de João Filgueiras Lima, parece acompanhar os novos projetos como os selecionados nesta edição. Revista a.U. São Paulo: ed. PINI,n.154, p.66-67, janeiro de 2007.

GHEZZI, Maria Inês Leal. Convivendo com o ser morrendo. Porto Alegre : Sagra: DC Luzzato, 1995

GODOI, A.F. Hotelaria hospitalar e humanização do atendimento em hospitais pensando e fazendo. São Paulo: Ícone, 2004

GÓES, R. Manual Prático de Arquitetura hospitalar.São Paulo: Ed. EdgardBlucher, $1^{\circ}$ Ed.,2004.

GOETHE, J. W. Doutrina das cores. São Paulo: Nova Alexandria, 1996

GOLDENSTEIN, Eduardo. Um estudo preliminar sobre humanização hospitalar: dando voz a médicos de UTI pediátrica sobre suas vivências em um hospital humanizado. São Paulo, 2006. Dissertação (mestrado psicologia clínica) - Pontifícia Universidade Católica de São Paulo

GUIMARÃES, G. João Filgueiras Lima: o último dos modernistas. São Carlos, 2003. Dissertação (mestrado). Escola de Engenharia de São Carlos. Universidade de São Paulo. 196p. 
HERTZBERGER,Herman. Lições de arquitetura .São Paulo : Ed. Martins Fontes,2006.

HOPKINSON, R. G. ; KAY, J.D. The lightning of buildings. New York: Frederick A. Praeger, Inc. Publishers, 1969

KARMAN, Jarbas. Manutenção hospitalar preditiva. São Paulo: Ed. PINI, 1994

KOENIGSBERGER, O.H.; INGERSOLL, T.G.; MAYHEW, Alan; SZOKOLAY, S.V. Vivendas y edifícios em zonas cálidas e tropicales. Madri: Paraninfo S.A. 1977.

LAMB, Paulo Lindolfo. Centro cirúrgico e recuperação pós-anestésica:planejamento. Porto Alegre: Gráficaplub, 2000

LATORRACA, G. João Filgueiras Lima, Lelé. Lisboa: Blau; São Paulo: Instituto Lina Bo e P.M Bardi, 1999

LEAL, Ledy Valporto. Sintonia da técnica com a criação: Hospital Sarah Kubschek. AU, Salvador, n.54, p62-67, jun./jul. 1994

LEÃO, Eliseth Ribeiro. Humanização Hospitalar. Disponível em: <http://www.eca.usp.br/ nucleos/nij/espiral/ciberia24b.htm> Acesso em: 07 março 2007

LEE, T. Psicologia e meio ambiente. Rio de Janeiro : Zahar, 1977. Ittelson, H. W., Proshansky, H. M., Rivlin, L.G., \& Winkel, G.H.An introduction to enviromenmental psychology. Nova York: Holt, Rinehart \& Winston, 1974

LIDA, Itira. Ergonomia: projeto e construção. São Paulo: Edgar Blüncher, 2002, 8aed.

LIMA, J. F. João Filgueiras Lima: entrevista.Salvador: Ed. Da Universidade,julho de 1985. Entrevistador: Péren, Jorge Isaac.

LIMA, João Filgueiras. CTRS Centro de Tecnologia da Rede Sarah. São Paulo: Fundação Bienal/ ProEditores, 1999

LUFT, C.P. Pequeno dicionário da língua portuguesa. São Paulo: Sapiane, s.d.

"Maggie's Higlhands". Disponível em: <http://www.pagepark.co.uk/> Acesso em: 10 de dezembro 2008
MALKIN, J. Hospital Interior Design. Nova York: Van Nostrand Reinhold, 1977.

MASCARÓ, Juan Carlos. O custo das decisões arquitetônicas nos projetos hospitalares. Brasilia, 1995. Ministério da Saúde - Série Saúde e Tecnologia - Textos de apoio à programação física dos estabelecimentos assistenciais de saúde.

MASCARELLO, V. L. D. Princípios Bioclimáticos e Princípios de Arquitetura ModernaEvidências no Edifício Hospitalar. Dissertação (Mestrado) - Faculdade de Arquitetura, Universidade Federal do Rio Grande do Sul, Porto Alegre, 2005.

MASETTI, Morgana. Soluç̃es de palhaços: transformações na realidade hospitalar. Nova York : Ed. Reinhold Publishing Corporation,1974.

MEDEIROS, Luciana de. Humanização hospitalar, ambiente físico e relações assistenciais: a percepção de arquitetos especialistas - Natal, 2004. Dissertação (mestrado em psicologia) - Programa de pós-graduação em psicologia, Universidade Federal do Rio Grande do Norte.

MEDEIROS, Walter. A Lei e a Humanização Hospitalar. Disponível em: <http://paginas. terra.com.br/arte/cordel/atendimento03_lei.htm> Acesso em: 07 março 2007.

MILLER, R., \& SWENSSON, E.S. New directions in hospital and healthcare design. Nova York:McGraw Hill, 1995. Carpman, J.R., Grant, M.. \&

MINAYO, M.C. Saúde e doença como expressão cultural, 1997. In. A.A.Filho\& M.C. Minayo (orgs.), SAÚDE, TRABALHO E FORMACC̃̃ PROFISSIONAL (pp. 31-39) Rio de Janeiro: Firenze.

MINISTÉRIO DA SAÚDE/ANVISA Resolução da Diretoria Colegiada n. ${ }^{\circ}$ 50. Normas para o Planejamento Fisico de Unidades de Saúde. Brasília, 2002.

MIQUELIN, Lauro Carlos. Anatomia dos edifícios hospitalares. São Paulo. CEDAS, 1992

MONTERO, Jorge Isaac Perén. Ventilação e iluminação naturais na obra de João Filguerias Lima, Lelé - Um estudo dos hostpitais da rede Sarah Kubstchek Fortaleza e Rio de Janeiro. São Carlos : s.n., 2006. Dissertacão (Mestrado - Programa de Pós-Graduação em Arquitetura e Urbanismo. Área de concentração: tencologia de Arquitetura e Urbanismo - Escola de Engenharia de São Carlos da Universidade de São Paulo). 
OKAMOTO, Jun. Percepção ambiental e comportamento. São Paulo: IPSIS, 1996.

PINTO, Antônio L. T.; WINDT, Márcia C. V. S.; CÉSPEDES, Lívia. Vade Mecum, São Paulo: Saraiva, 2009.

PINTO, Sylvia Caldas Ferreira. Hospitais: planejamento fisico de unidades de nível secundário. Brasília: Thesaurus, 1996.

PRUDENTE, Gustavo. Atividades Destinadas a Humanizar Hospitais ganham Adeptos. Disponivel em: <http://www1.folha.uol.com.br/folha/equilibrio/noticias/ ult263u3853.shtml> Acesso em: 07 março 2007.

REIS, Fernanda Del Santoro. 0 ambiente como recurso terapêutico nos serviços públicos de saúde - Campinas, 2000. Monografia (graduação em terapia ocupacional) - Faculdade de Terapia Ocupacional, Pontifícia Universidade Católica de Campinas.

REMEN, R.N. O paciente como ser humano. São Paulo: Summus, 1993.

RIBEIRO, Lisandra M. Humanização do Espaço Arquitetônico em Unidade de Hemodiálise. Monografia (Especialização) - Programa de Pós-Graduação em Arquitetura. Faculdade de Arquitetura, Universidade Federal da Bahia, 2008.

RIVERO, R. Acondicionamento térmico natural: arquitetura e clima. Porto Alegre :Ed Da Universidade, 1985.

ROBBINS, Claude L. Daylighting: design analysis. New York: Van Nostrand Reinhold Company, 1986.

ROCHA, Márcia Matos Brandão. Detalhes arquitetônicos em unidades de internação pediátrica - Salvador, 2008. Monografia (Especialização em Arquitetura de Sistemas de Saúde) - Universidade Federal da Bahia.

RORIZ, M. Zona de conforto térmico: um estudo comparativo de diferentes abordagens. São Carlos, 1987. Dissertação (mestrado). Escola de Engenharia de São Carlos. Universidade de São Paulo. 133p.

ROSENFIELD, Isadore. Hospitals: integrated design .Nova York : Ed. Reinhold Publishing Corporation, 1974
SAMPAIO, Ana Virgínia Carvalhães de Faria. Arquitetura Hospitalar: projetos ambientalmente sustentáveis, conforto e qualidade. São Paulo, 2005. Dissertação (Doutorado em estruturas ambientais urbanas).Faculdade de Arquitetura e Urbanismo da Universidade de São Paulo.

SAN JUAN, C. Ambientes Institucionales, 1998.In. J. I. Aragonés \& M. Amérigo (Orgs.), Psicologia Ambiental (pp.237-257) Madri: Pirâmide.

SANTOS, C.T. \& SEBASTIANI, R.W. Acompanhamento psicológico à pessoa portadora de doença crônica. In V.A Angerami-Camon (Org). E a Psicologia entrou no hospital. (pp.147-176). São Paulo:Pioneira, 2001

SILVA, Kleber Pinto. A Idéia de Função Para a Arquitetura: o Hospital e o Século XVIII - parte 6/6. Disponivel em: <http://www.vitruvius.com.br/arquitextos/arq000/esp111.asp> Acesso em: 07 março 2007

SIMMONS, D.A.Design that cares: planning health facilities and visitors. Chicago:American Hospital Association. 1986.

TOLEDO, Luiz Carlos de Menezes. Feitos para curar - arquitetura hospitalar e processo projetual no Brasil. Rio de Janeiro: ABDEH,2006.

TOLEDO, Luiz Carlos de Menezes. "humanização do edifício hospitalar - tema em aberto." In. DUARTE, Cristiane R.; RHEINGANTZ, Paulo A.; AZEVEDO, Giselie; BRONSTEIN, Lais. (Org). 0 Lugar do Projeto. 01 ed. Rio de Janiero: Contra Capa, 2007, v.01, p. 436-446.

TRAVERSO-YÉPEZ, M. A interface psicologia social e saúde: perspectivas e desafios. Psicologia em Estudo, 6, (2), 49-56, 2001

VASCONCELOS, Renata Thaís Bomm. Humanização de Ambientes Hospitalares: Características Arquitetônicas Responsáveis pela Integração Interior/Exterior. Dissertação (Mestrado) - Programa de Pós-Graduação em Arquitetura e Urbanismo Universidade Federal de Santa Catarina, Florianópolis, 2004.

VIANNA, Nelson S: GONCALVES, Joana C. S. Iluminação e Arquitetura. São Paulo: Virtus, 2001 
